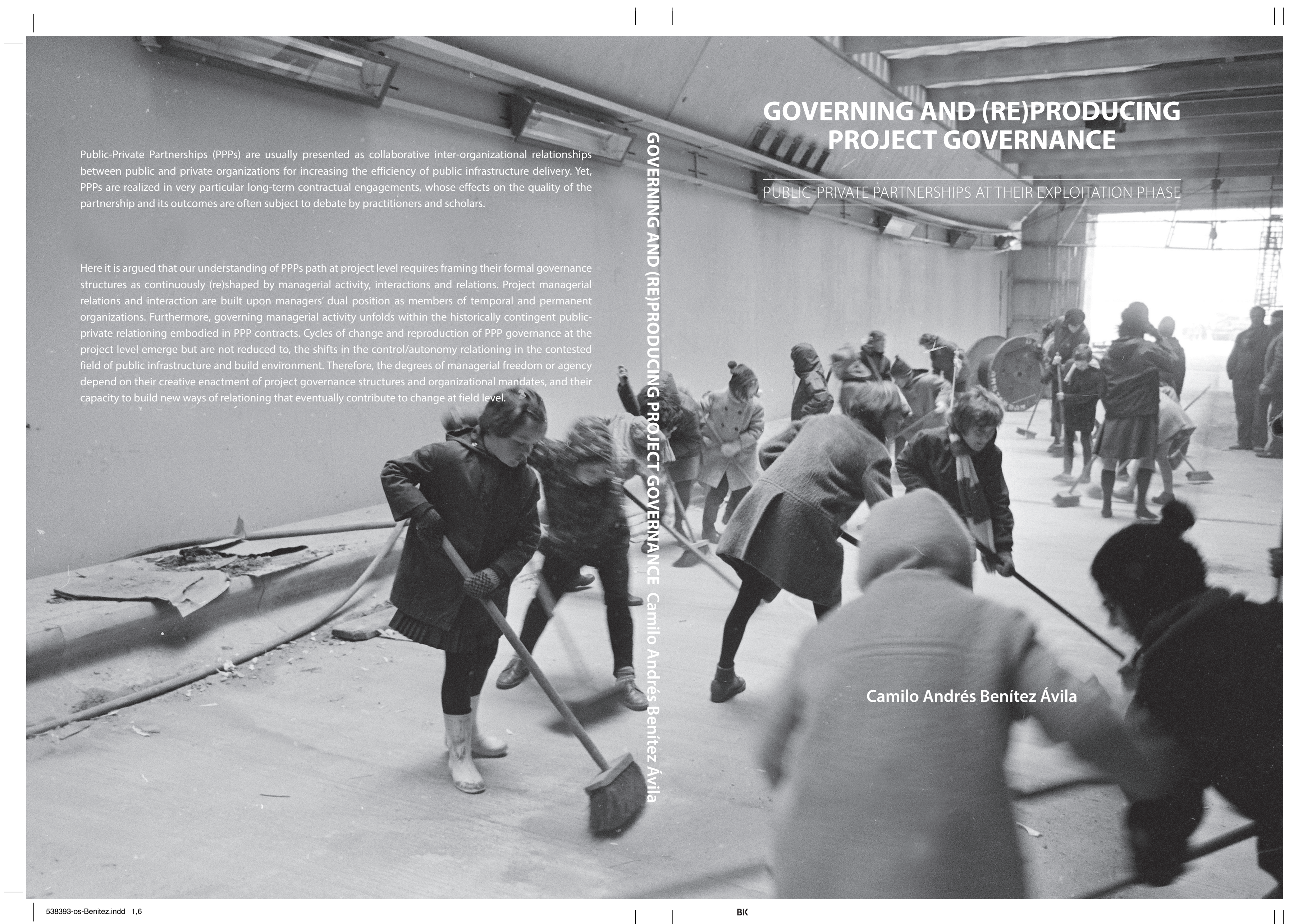

INVITATION

To the defence of the PhD dissertation entitled

GOVERNING AND

(RE)PRODUCING PROJECT GOVERNANCE

\title{
By
}

Camilo Andrés Benítez Ávila

On Thursday 5 December 2019 At 12:45 hours in the

Waaier, 4 - Prof.dr. G. Berkhoff-zaal, Enschede, the Netherlands

Following the ceremony there will be a reception.

Camilo Andrés Benítez Ávila c.a.benitezavila@utwente.nl

Paranymphs:

Marc van den Berg

and Denis Makarov 


\section{GOVERNING AND (RE)PRODUCING PROJECT GOVERNANCE}

PUBLIC-PRIVATE PARTNERSHIPS AT THEIR EXPLOITATION PHASE

Camilo Andrés Benítez Ávila 
This dissertation has been approved by:

\section{Supervisor}

Prof.dr. G.P.M.R. Dewulf

\section{Co-supervisor}

Dr. A. Hartmann

Cover design: Ipskampprint.nl - ANP Photo/Cor Mulder

Printed by: Ipskampprinting.nl

Lay-out: Legatron Electronic Publishing

ISBN: 978-90-365-4901-1

DOI: https://doi.org/10.3990/1.97890365490011

Cover photograph: "Springtime - cleaning time: that applies not only to the Dutch indoor houses but also to infrastructure works such as the Coentunnel, which was scrubbed clean by an enthusiastic team of children on Friday" 15 April 1966, The Netherlands National News Agency (ANP) - Photo archives, 1963-1968. Photo: Cor Mulder

(c) 2019 Camilo Andres Benitez Avila, The Netherlands. All rights reserved. No parts of this thesis may be reproduced, stored in a retrieval system or transmitted in any form or by any means without permission of the author. Alle rechten voorbehouden. Niets uit deze uitgave mag worden vermenigvuldigd, in enige vorm of op enige wijze, zonder voorafgaande schriftelijke toestemming van de auteur. 


\title{
GOVERNING AND (RE)PRODUCING PROJECT GOVERNANCE
}

\author{
PUBLIC-PRIVATE PARTNERSHIPS ATTHEIR EXPLOITATION PHASE
}

\author{
DISSERTATION
}

to obtain

the degree of doctor at the Universiteit Twente,

on the authority of the rector magnificus,

Prof.dr. T.T.M. Palstra,

on account of the decision of the graduation committee

to be publicly defended

on Thursday 5 December 2019 at 12.45 uur

by

\section{Camilo Andrés Benítez Ávila}

born on the $2^{\text {nd }}$ of June 1984

in Bogotá, Colombia 


\section{Graduation Committee}

Chairman / secretary: prof.dr. G.P.M.R. Dewulf

Supervisor: $\quad$ prof.dr.ir. G.P.M.R. Dewulf

Co-supervisor: $\quad$ dr. A. Hartmann

Committee Members: prof.dr. A.C. Davies prof.dr. J. Roehrich prof.dr. K. Verhoest prof.dr. R. Torenvlied prof.dr.ir. L. Volker 
Para Martha y Daniel 
SUMMARY XI

SAMENVATTING XV XV X

INTRODUCTION

$\begin{array}{ll}\text { PUBLIC-PRIVATE PARTNERSHIPS AND GOVERNANCE } & 1\end{array}$

Consequences for the Maintenance and Operation Phases 3

The Dynamic Nature of Public-Private Partnerships 4

THE TURN-TO-SOCIAL THEORY FOR STUDYING PROJECTS AS THEY ACTUALLY ARE 5

Project Governance, Agency and Structure $\quad 6$

$\begin{array}{lr}\text { PROBLEM STATEMENT } & 8\end{array}$

RESEARCH APPROACH

$\begin{array}{lr}\text { RESEARCH DESIGN } & 10\end{array}$

$\begin{array}{ll}\text { THESIS OUTLINE } & 14\end{array}$

CHAPTER 1: INTERPLAY OF RELATIONAL AND CONTRACTUAL GOVERNANCE 17 IN PUBLIC-PRIVATE PARTNERSHIPS: THE MEDIATING ROLE OF RELATIONAL NORMS, TRUST AND PARTNERS' CONTRIBUTION

$\begin{array}{ll}\text { ABSTRACT } & 17\end{array}$

$\begin{array}{lll}1.1 & \text { INTRODUCTION } & 18\end{array}$

1.2 CONTRACTUAL AND RELATIONAL GOVERNANCE IN PPP PROJECTS 20

$\begin{array}{lll}\text { 1.2.1 Project Performance and Partners' Contribution } & 21\end{array}$

$\begin{array}{ll}\text { 1.2.2 Contractual Governance } & 22\end{array}$

1.2.3 Relational Governance Elements 23

1.2.4 Relational Governance Elements as Mediators of Contractual Governance 24

$\begin{array}{ll}1.3 & \text { RESEARCH DESIGN } \\ & 26\end{array}$

$\begin{array}{lll}\text { 1.3.1 Survey and Data Collection } & 26\end{array}$

$\begin{array}{ll}\text { 1.3.2 Method } & 26\end{array}$

$\begin{array}{ll}\text { 1.3.3 Measurement Model } & 27\end{array}$

$\begin{array}{lll}1.4 & \text { RESULTS } & 29\end{array}$

1.4.1 Overall Fit of the Model 29

$\begin{array}{ll}1.4 .2 & \text { Measurement Model } \\ 1.4 .3 & 29\end{array}$

$\begin{array}{lll}\text { 1.4.3 Structural Model and Hypothesis Testing } & 31\end{array}$

$\begin{array}{lll}\text { 1.4.4 Moderation Analysis } & 33\end{array}$

$\begin{array}{lll}1.5 & \text { DISCUSSION } & 34\end{array}$

1.5.1 Interpreting Mediation: Enabling Mechanism $\quad 35$

1.5.2 Interpreting Mediation: Compensating Mechanism 36

1.5.3 Interpreting Mediation: Moderating Effect of Project Complexity 36

$\begin{array}{ll}\text { 1.5.4 Managerial Implications } & 37\end{array}$ 
$\begin{array}{lll}1.5 .5 & \text { Limitations } & 37\end{array}$

$\begin{array}{lll}1.6 & \text { CONCLUSION } & 37\end{array}$

CHAPTER 2: CONTRACTUAL AND RELATIONAL GOVERNANCE AS POSITIONED 39 -PRACTICES IN ONGOING PUBLIC-PRIVATE PARTNERSHIP PROJECTS

$\begin{array}{ll}\text { ABSTRACT } & 39\end{array}$

$\begin{array}{lll}2.1 & \text { INTRODUCTION } & 40\end{array}$

2.2 CONTRACTUAL AND RELATIONAL INTERPLAY IN PPPS

2.3 REALIST SOCIAL THEORY FOR STUDYING GOVERNING ACTIVITY

2.3.1 Governance Structures and Situational Logics 44

2.3.2 Governing Activity: Positioned-Practices and Reflexivity 45

2.3.3 Cycles of Interplay and Levels of Change 47

2.4 TOWARD A PROCESS FRAMEWORK OF GOVERNING ACTIVITY IN ONGOING PPPS 48

2.5 ILLUSTRATIVE CASE

2.5.1 Approach and Methods $\quad 52$

2.5.2 Functional Change as a Triggering Event 53

2.5.3 Governing Activity 53

2.5.4 Complementarity/Substitution from a Dynamic Perspective 54

2.5.5 Cycles of Governing Activity and Underlying Managerial Struggle $\quad 55$

$\begin{array}{ll}2.6 & \text { DISCUSSION } \\ & 57\end{array}$

2.6.1 Complexity of the Interplay Between Contractual and Relational Governance 58

2.6.2 Governing Activity and Governance Structure 58

2.6.3 Governance and Institutional Complexity in Ongoing Public-Private 59 Partnerships

$\begin{array}{llr}2.7 & \text { CONCLUSION } & 60\end{array}$

CHAPTER 3: GOVERNANCE OF TEMPORARY ORGANIZING IN THE CHANGING 63 FIELD OF PUBLIC-PRIVATE PARTNERSHIPS

$\begin{array}{ll}\text { ABSTRACT } & 63\end{array}$

3.1 INTRODUCTION 64

3.2 AGENCY, STRUCTURE AND GOVERNANCE OF TEMPORARY ORGANIZING 66

3.2.1 The Structuration Perspective and the Idea of Mutual Constitution 66

3.2.2 The Perspective of Analytical Dualism and the Morphogenetic Approach 68

$\begin{array}{lll}3.3 & \text { RESEARCH CONTEXT } & 71\end{array}$

$\begin{array}{lll}3.4 & \text { RESEARCH DESIGN } & 73\end{array}$

$\begin{array}{lll}3.4 .1 & \text { Case Studies } & 73\end{array}$

$\begin{array}{lll}\text { 3.4.2 Analytical tactics } & 74\end{array}$

$\begin{array}{lll}3.5 & \text { RESULTS } & 78\end{array}$

3.5.1 Case 1: N31 Strong Collaboration in a Partnership 78

3.5.2 Case 2: II Coen Tunnel: Common Ground for Addressing Problems in a 82 Working Relationship

3.5.3 Case 3: N33 Tense interaction Upon a Contractual Relationship 88

$\begin{array}{ll}\text { 3.5.4 Analysis of the Contextual Embeddedness } & 94\end{array}$ 
3.6 DISCUSSION

3.6.1 Permanent and Temporary Organizing as Different Strata of Social 98 Organizing

3.6.2 Articulation of Positions, Vested Interests and Relations to Practices 100

3.6.3 Morphogenetic Times Beyond Objective and Subjective Times 101

$\begin{array}{lll}3.7 & \text { CONCLUSION } & 102\end{array}$

CHAPTER 4: THE "3P CHALLENGE " - REFLECTING ON THE SENSE OF 105

PARTNERSHIP IN PUBLIC-PRIVATE CONCESSIONS

$\begin{array}{ll}\text { ABSTRACT } & 105\end{array}$

$\begin{array}{llr}4.1 & \text { INTRODUCTION } & 106\end{array}$

$\begin{array}{lll}4.2 & \text { THEORETICAL BACKGROUND } & 107\end{array}$

4.2.1 Process Management of Public Private Partnerships 107

4.2.2 Dual Position of Project Managers 109

$\begin{array}{lll}\text { 4.3 METHODOLOGICAL CONSIDERATIONS OF GAMING } & 110\end{array}$

$\begin{array}{ll}4.4 \text { THE "3P CHALLENGE" GAME } & 110\end{array}$

4.4.1 Design Specifications 110

4.4.2 Game Session Arrangement 113

4.4.3 Prototyping, Testing and Evaluation With Students $\quad 114$

$\begin{array}{ll}\text { 4.4.4 Game Sessions With Practitioners } & 116\end{array}$

$\begin{array}{lll}4.5 & \text { RESULTS } & 116\end{array}$

4.5.1 First Game Session - Market/Project Level Outcomes 116

4.5.2 First Game Session - Reflection on PPP Practice 120

4.5.3 Second Game Session - Market/Project Level Outcomes 121

4.5.4 Second Game Session - Reflection on PPP Practice 123

$\begin{array}{lll}4.6 & \text { DISCUSSION } & 124\end{array}$

$\begin{array}{lll}4.7 & \text { CONCLUSION } & 127\end{array}$

$\begin{array}{lll}4.8 & \text { ANNEX: SYSTEM DYNAMICS GAMING PLATFORM } & 128\end{array}$

$\begin{array}{ll}\text { CONCLUSION } & 133\end{array}$

$\begin{array}{ll}\text { THEORETICAL CONTRIBUTION } & 138\end{array}$

$\begin{array}{ll}\text { METHODOLOGICAL CONTRIBUTION } & 141\end{array}$

$\begin{array}{ll}\text { PRACTICAL CONTRIBUTION } & 142\end{array}$

$\begin{array}{ll}\text { LIMITATIONS AND FURTHER RESEARCH } & 143\end{array}$

$\begin{array}{ll}\text { AKNOWLEDGEMENTS } & 145\end{array}$

$\begin{array}{ll}\text { REFERENCES } & 147\end{array}$ 


\section{SUMMARY}

Public-PrivatePartnerships (PPPs) are usually presented as collaborative inter-organizational relationships between public and private organizations for improving the delivery of public infrastructure. Yet, PPPs are realized in very particular long-term contractual engagements whose effects on the quality of the partnership and its outcomes are often subject to debate by practitioners and scholars. The variance of assessment brings to the light the need to understand why PPP projects emerge and evolve in the way they do, beyond the performative promises of front-end arrangements usually shaped by economic and engineering thinking. These traditional lenses for understanding PPP project governance overlook that projects are open systems, contingent to socio-historical processes and to the creative powers of human activity re-creating forms of organizing. In this regard, the recent turn to social theories is a promising but unexplored alternative for extending our understanding of the actuality of project governance within the agency and structure debate. Accordingly, this thesis aims at addressing the complex and dynamic nature of governing activity in ongoing PPPs by answering: How do managerial agency and project governance structures rely on and re-shape each other during the operational and maintenance (O\&M) phase of PPPs? For answering the main questions, we postulate an explanatory mechanism accounting for observable PPP governing activity within the process of (re)production of PPP governance structure and project governing activity. This research is influenced by the critical realist approach to studying organization life, and it takes as empirical context the execution of DesignBuild-Finance-Maintain and Operate (DBFM-O) contracts in the Netherlands.

In Chapter 1, we aim to empirically test whether the relationship between informal and formal governance mechanisms follows the tenets of neo-institutional economics. In particular, we test a conceptual model built upon the proposition that informal aspects of governance mediate formal contracts and behaviours. This study uses a confirmatory theory testing approach based on updated Structural Equation Modeling - Consistent Partial Least Squares (SEM-PLSC) guidelines to validate our theoretical model by assessing the overall fit of the model. Data was collected through a survey of private and public managers involved in officially known PPP projects in the Netherlands ( $n=157)$. Our results (empirically) explain project performance as the result of a mediation process. Relational governance elements (relational norms and trust) play their mediating role on the blueprint provided by contractual governance elements, and translate these contractual provisions into contributions of project partners leading to performance outcomes. Additionally, higher uncertainty requires stronger joint management, increasing the relevance of relational norms addressing emerging issues. Relational norms initially emerge from the implementation of discrete contractual choice and then turn into an implicit understanding sanctioned by the strength of the informal ties built between partners. These findings allow us to move away from the static dichotomy substitution/complementarity to the process by which structural governance characteristics are mediated by the relational powers of managerial agency.

In Chapter 2, we re-frame the results obtained in the first stage as a non-observable mechanism accounting for observable governing activity and unfolding in the complex process of project 
governance change. Accordingly, we introduce the sociological discussion of agency and structure interplay to better elaborate our initial process insights into contractual and relational governance. The framework of reference is the so-called morphogenetic approach (Archer, 1995). The governing activity we see in the present is the outcome of creative human mediation of structural governance shaped in the past. Therefore, governing activity can change the project governance structures for the future. In this cycle, the point of contact between agency and structure is the so-called positioned-practices. Enforcing contracts, bringing together stakeholders or engaging informal dialogues are positionedpractices, enacted and recreated by virtue of managers' dual positions at both the project and the parent organizational levels. The postulated explanatory mechanism is the managerial capacity to reflect and bring creativity to conceal (or prioritize) multiple demands. These demands are imposed on managers due to their dual positions at the project and organizational level. The project is regarded as a temporal but necessary relationship that predisposes (but does not mechanically determine) actors to engage solidarity or concessional ways of interactions, while the permanent is conceptualized as contingent relation between parent organizations predisposing (but not mechanically leading) the same actors to competition and opportunism. We use a DBFM-O project in its exploitation phase to illustrate the operation of this explanatory mechanism. This mechanism explains the observable governing activity as well as the reproduction and change of project governance.

Chapter 3 focuses on how managers attend multiple demands due to their dual position in the exploitation phase of PPPs; examining to which extent the initial project governance structure remains stable. This research stage allowed us to place in context the process mechanism defined in the second stage; comparing the paths of three DBFM projects at their operational and maintenance phase in the Netherlands. Having a detailed observation of each cycle of (re)production of project governance structure allows us to clarify how the hypothesized mechanism works in a broader context. Problematic situations are experienced by project managers as a demand to capture value for their organizations, given their contingent relationship outside the temporal agreement. This contingent relation predisposes managers to unilaterally act without considering how this might affect counterpart (opportunity) or capture deteriorating counterpart value (conflict). What the dual position entails is a temporal but necessary relationship which turns value capture into a value co-creation issue, as project managers are demanded to define extra investments to deal with the situation. Whether the problem is addressed within the temporal boundaries or escalated at the level of parent organizations is a matter of project capacity. Beyond pure material resources, capacity depends on relational goods emerging from the subjective interaction of managers upon collective reflection on objective contractual and organizational bounds. We found that attributing meaning to the contract beyond legal entitlements allowed managers to conceal the tension of value capture for parent organizations and value cocreation at the project level. However, putting meaning to contractual entitlements in a non-pure legal fashion was predisposed by the initial terms of the PPP agreement, and the contingent outcomes of previous cycles of interaction. In this regard, the dynamics of collaboration and conflict at the project level remained dependent on the cycles of (re)production of each public-private agreement rather than as a consequence of the changes of policy values in the Dutch context.

In Chapter 4, we introduce the serious game "3P challenge" as a vehicle to reflect with practitioners on their working relationships during the exploitation phase of PPPs. The game design is based on the insights from the analytical research cycle, aiming at activating participants reflexivity to consider the 
diverse demands they face as project managers (Donati, 2010). The game was played in two sessions in the Netherlands, one with a mixed group of infrastructure professionals including some PPPs experts, and another one with a team of PPPs public contract managers. The game dynamics offered a space for collaboration on the project level but also activated mechanisms preventing players for making use of this space. The gaming experience allowed to make the point that managers can implement contractual mechanisms without much communication, or communicate with the other party about what needs to be implemented. In the session played with a group of mixed practitioners, participants pointed out the similarity between the experience during the game and the ongoing discussion of PPPs at the policy level. At the moment, the Dutch authority and market were less enthusiastic about engaging new PPPs given the low margin of profit and high risk for contractors. In the case of contract project managers, the same gaming experience allowed them to articulate how they can reflect on the objective demands of the contract as well as the top-down pressures of organizations. The discussion brought to light the characterization of their role as brokers of varied interests by blending the contract to move the project forward, addressing poor ex-ante choices, and dealing with uncertainty.

Research influenced by a realist critical approach is necessarily a theoretical driven scientific endeavor. In this regard, our contribution was building and revisiting the current conceptualization of governance in the light of the turn-to-practice in project management (Floricel, Bonneau, Aubry, \& Sergi, 2014), temporal organizing as a co-evolving process (Sydow \& Braun, 2017), and PPP process management (Edelenbos \& Klijn, 2009; Klijn, 2008). We contribute to the turn-to-practice in project management, making more salient the nature of structures as positions linked to practices in cycles of project governance change and reproduction. In this regard, we articulate governing practices to the stratified view of project governance that pushes managers to comply with their dual role as part of permanent and temporal organizations. Along the same lines, our contribution to temporal organizing is clearly defining the interface of temporal and permanent in long-term and time-bounded agreements. Additionally, we frame process management for concessional partnerships as the creative enactment of contractual relations. Meaning, situations where managers build a collaborative working relationship based upon but not reduced to contractual entitlements. The working relationship provides managers grounds for re-legitimizing the fairness and clarity of the contractual entitlements. This thesis also contributed at the methodological level, taking into account the scope of each stage of research following the critical realist logic of discovery/explanation. In terms of practical contribution, we point out that four key potential conflictive situations should be noticed during the O\&M phase, which - if well resolved - can facilitate trust development as relational good. Furthermore, the actual value for money (providing either higher quality for the same level of public investment or lower investment for the same level of quality) depends on addressing these points. We also point out that the social contribution of practical sociology is bringing to light the mechanisms of social change and, by doing so, confronting the hypnotic power of the PPPs manifested in its acritical popularity and also fierce critics. 


\section{SAMENVATTING}

Publiek-Private Samenwerking (PPS's) worden meestal gepresenteerd als samenwerkingsverbanden tussen publieke en private organisaties voor het verbeteren van de levering van publieke infrastructuur. Toch komen PPS's tot uiting in zeer specifieke contractuele verplichtingen op lange termijn, die gevolgen hebben voor de kwaliteit van het partnerschap en de resultaten ervan, en die vaak het onderwerp zijn voor een discussie tussen mensen uit de praktijk en wetenschappers. De verschillen in de beoordeling maken duidelijk dat het noodzakelijk is om te begrijpen waarom PPS-projecten ontstaan en evolueren op de manier waarop ze zich ontwikkelen, naast de performatieve beloften van front-end arrangementen die gewoonlijk gebaseerd zijn op economisch en technisch denken. Deze traditionele inzichten voor het begrijpen van PPS-projectbeheer gaan voorbij aan het feit dat projecten open systemen zijn, die afhankelijk zijn van sociaalhistorische processen en van het creatieve vermogen van de mens om opnieuw vormen van organisatie te creëren. In dit opzicht is de recente wending naar sociale theorieën een veelbelovend maar onontdekt alternatief voor het uitbreiden van ons begrip van de actualiteit van projectbesturing binnen het agentschaps- en structuurdebat. Dit proefschrift beoogt dan ook de complexe en dynamische aard van het besturen van activiteiten in lopende PPS's aan te pakken door hierop te antwoorden: Hoe gaan management agency en project governance structuren uit van elkaar en hoe vormen ze elkaar tijdens de Operationele en Onderhoudsfase (O\&M) van PPS's? Voor de beantwoording van de belangrijkste vragen stellen we een verklaringsmechanisme voor dat rekening houdt met waarneembare PPS-besturingsactiviteiten binnen het proces van (her)productie van de PPS-governancestructuur en de projectbesturingsactiviteit. Dit onderzoek is gebaseerd op de kritisch-realistische benadering van het bestuderen van het organisatieleven en neemt als empirische context de uitvoering van Design-Build-Finance-Maintain and Operate (DBFM-O) contracten in Nederland als uitgangspunt.

In hoofdstuk 1 willen we empirisch testen of de relatie tussen informele en formele bestuursmechanismen de huurders van de neo-institutionele economie volgt. In het bijzonder testen we een conceptueel model dat gebaseerd is op de onderliggende stelling dat informele aspecten van governance formele contracten en gedragingen bemiddelen. Deze studie gebruikt een bevestigende theorie en een testende benadering die gebaseerd is op bijgewerkte Structural Equation Modeling Consistente Partial Least Squares (SEM-PLSc) richtlijnen om ons theoretisch model te valideren door de algemene fit van het model te beoordelen. De gegevens werden verzameld door middel van een enquête onder private en publieke managers die betrokken zijn bij officieel bekende PPS-projecten in Nederland ( $n=157)$. Onze resultaten (empirisch) verklaren de prestaties van het project als resultaat van een bemiddelingsproces. Relationele governance-elementen (relationele normen en vertrouwen) spelen hun bemiddelende rol in de blauwdruk van de contractuele governance-elementen en vertalen deze contractuele bepalingen in bijdragen van de projectpartners die leiden tot prestatie-uitkomsten. Bovendien vereist een hogere onzekerheid een sterker gezamenlijk beheer, waardoor de relevantie van relationele normen voor opkomende problemen toeneemt. Relationele normen komen in eerste instantie voort uit de implementatie van discrete contractuele keuzes, en worden vervolgens omgezet in een impliciet begrip dat wordt bekrachtigd door de sterkte van de informele banden die tussen 
partners worden opgebouwd. Deze bevindingen stellen ons in staat om van de statische dichotomie substitutie/complementariteit over te stappen naar het proces waarbij structurele bestuurskenmerken worden gemedieerd door de relationele krachten van de managementorganisatie.

In hoofdstuk 2 herformuleren we de resultaten van de eerste fase als een niet-waarneembaar mechanisme dat de waarneembare bestuursactiviteit verantwoordt en zich ontvouwt in het complexe proces van projectgovernanceverandering. Daarom introduceren we de sociologische discussie over de interactie tussen agentschap en structuur om onze eerste inzichten in het proces van contractuele en relationele governance beter uit te werken. Het referentiekader is de zogenaamde morfogenetische benadering (Archer, 1995). De regerende activiteit die we in het heden zien is het resultaat van een creatieve menselijke bemiddeling van structureel bestuur dat in het verleden vorm heeft gekregen. Daarom kan regerende activiteit de projectbesturingsstructuren voor de toekomst veranderen. In deze cyclus is het contactpunt tussen instantie en structuur de zogenaamde positioneringspraktijken. Het afdwingen van contracten, het samenbrengen van belanghebbenden of het aangaan van informele dialogen worden gepositioneerd - praktijken die worden vastgesteld en opnieuw tot stand gebracht op basis van de dubbele posities van managers op zowel het project- als het moederorganisatieniveau. Het veronderstelde verklarende mechanisme is het bestuurlijk vermogen om na te denken en creativiteit te brengen om meerdere eisen te verbergen (of prioriteiten te stellen). Deze eisen worden opgelegd aan managers vanwege hun dubbele functie op project- en organisatieniveau. Het project wordt beschouwd als een tijdelijke maar noodzakelijke relatie die actoren ertoe aanzet (maar niet mechanisch bepaalt) om solidariteit of concessionele manieren van interactie aan te gaan, terwijl het permanente wordt geconceptualiseerd als een voorwaardelijke relatie tussen moederorganisaties die dezelfde actoren tot concurrentie en opportunisme aanzetten (maar niet mechanisch leiden). We gebruiken een DBFM-O project in de exploitatiefase om de werking van dit verklarende mechanisme te illustreren. Dit mechanisme verklaart de waarneembare bestuursactiviteit, alsook de reproductie en verandering van het projectmanagement.

Hoofdstuk 3 gaat in op de manier waarop managers meerdere aanvragen in behandeling nemen vanwege hun dubbele functie in de exploitatiefase van PPS en onderzoekt in welke mate de oorspronkelijke projectgovernancestructuur stabiel blijft. In deze onderzoeksfase konden we het in de tweede fase gedefinieerde procesmechanisme in zijn context plaatsen; het vergelijken van de paden van drie DBFM-projecten in hun Operationele en Onderhoudsfase in Nederland. Met een gedetailleerde observatie van elke cyclus van (her)productie van de projectgovernancestructuur kunnen we verduidelijken hoe het veronderstelde mechanisme in een bredere context werkt. Problematische situaties worden door projectmanagers ervaren als een vraag om waarde voor hun organisaties vast te leggen, gezien hun voorwaardelijke relatie buiten de tijdelijke overeenkomst om. Deze voorwaardelijke relatie dwingt managers om eenzijdig te handelen zonder na te denken over hoe ze de tegenhanger (opportuniteit) of de verslechterende tegenwaarde (conflict) zouden kunnen beïnvloeden. Wat de dubbele positie met zich meebrengt is een tijdelijke maar noodzakelijke relatie die van waardevastlegging een kwestie van waarde co-creatie maakt, aangezien projectmanagers extra-investeringen moeten definiëren om met de situatie om te gaan. Of het probleem binnen de tijdsgrenzen wordt aangepakt of geëscaleerd op het niveau van de moederorganisaties is een kwestie van projectcapaciteit. Naast pure materiële middelen is capaciteit afhankelijk van relationele goederen die voortkomen uit de subjectieve interactie van managers op basis van collectieve 
reflectie over objectieve contractuele en organisatorische grenzen. We vonden dat het toekennen van betekenis aan het contract buiten de wettelijke rechten, managers in staat stelde om de spanning van waardevastlegging voor moederorganisaties en waardeco-creatie op projectniveau te verbergen. Het feit dat contractuele rechten op een niet-zuivere juridische manier betekenis hebben gegeven aan contractuele rechten werd echter ingegeven door de aanvankelijke voorwaarden van de PPSovereenkomst en de voorwaardelijke resultaten van eerdere cycli van interactie. De dynamiek van samenwerking en conflicten op projectniveau bleef daarbij afhankelijk van de cycli van (her)productie van elke publiek-private overeenkomst en niet zozeer van de veranderende beleidswaarden in de Nederlandse context.

In hoofdstuk 4 introduceren we het serious game "3P challenge" als een middel om met de praktijk te reflecteren op hun werkrelaties tijdens de exploitatiefase van PPS. Het spelontwerp is gebaseerd op de inzichten uit de analytische onderzoekscyclus, met als doel het activeren van de reflexiviteit van de deelnemers om rekening te houden met de verschillende eisen die zij als projectmanager stellen (Donati, 2010). Het spel werd gespeeld in twee sessies in Nederland, één met een gemengde groep van infrastructuurprofessionals, waaronder enkele PPS-experts, en één met een team van PPS-opdrachtgevers. De speldynamiek bood ruimte voor samenwerking op projectniveau, maar activeerde ook mechanismen die spelers ervan weerhielden om van deze ruimte gebruik te maken. De spelervaring maakte het mogelijk om aan te geven dat managers contractuele mechanismen kunnen implementeren zonder veel communicatie, of met de andere partij kunnen communiceren over wat je moet implementeren. In de sessie gespeeld met een groep van mixed practitioners wezen de deelnemers op de gelijkenis tussen de ervaring tijdens het spel en de voortdurende discussie over PPS op beleidsniveau. Op dit moment zijn de Nederlandse overheid en de markt minder enthousiast over het aangaan van nieuwe PPS'en vanwege de lage winstmarge en het hoge risico voor aannemers. In het geval van contractprojectmanagers konden zij op basis van dezelfde spelervaring aangeven hoe zij kunnen reflecteren op de objectieve eisen van het contract en op de top-down druk van organisaties. De discussie bracht de karakterisering van hun rol als makelaar met uiteenlopende belangen aan het licht, door het contract te vermengen om het project vooruit te helpen, slechte ex ante keuzes aan te pakken en om te gaan met onzekerheid.

Het onderzoek op basis van een realistische kritische benadering is noodzakelijkerwijs een theoretisch-gedreven wetenschappelijke inspanning. In dit opzicht was onze bijdrage het opbouwen en herzien van de huidige conceptualisering van governance in het kader van de turn-to-practice in projectmanagement (Floricel et al., 2014), tijdelijke organisatie als een co-evolutieproces (Sydow \& Braun, 2017), en PPS-procesmanagement (Edelenbos \& Klijn, 2009; Klijn, 2008). Wij dragen bij aan de turn-to-practice in projectmanagement, waardoor de aard van structuren als functies die gekoppeld zijn aan de praktijk in cycli van projectgovernanceverandering en -reproductie meer in het oog springen. In dit verband verwoorden we de bestuurspraktijk naar de gelaagde visie op project governance, die managers ertoe aanzet om hun dubbele rol als onderdeel van vaste en tijdelijke organisaties te vervullen. In dezelfde zin is onze bijdrage aan de temporele organisatie duidelijk de interface van tijdelijke en permanente overeenkomsten op lange termijn. Daarnaast kaderen we procesmanagement voor concessionele samenwerkingsverbanden als de creatieve vaststelling van contractuele relaties. Dit wil zeggen, situaties waarin managers een samenwerkingsverband opbouwen op basis van maar niet gereduceerd tot contractuele rechten. De werkrelatie biedt managers redenen om de eerlijkheid 
en duidelijkheid van de contractuele rechten opnieuw te legitimeren. Dit proefschrift droeg ook bij op methodologisch niveau, rekening houdend met de reikwijdte van elke onderzoeksfase volgens de kritisch-realistische logica van de ontdekking/uitleg. Wat de praktische bijdrage betreft, wijzen we erop dat er in de O\&M-fase vier belangrijke potentiële conflictsituaties moeten worden opgemerkt die, mits goed opgelost, de ontwikkeling van vertrouwen als relationeel goed kunnen bevorderen. Bovendien hangt de werkelijke Value for Money (het bieden van een hogere kwaliteit voor hetzelfde niveau van overheidsinvesteringen of een lagere investering voor hetzelfde kwaliteitsniveau) af van het aanpakken van deze punten. We wijzen er ook op dat de maatschappelijke bijdrage van de praktische sociologie de mechanismen van maatschappelijke verandering aan het licht brengt en daarmee de hypnotiserende kracht van de PPS'en, die zich uiten in hun kritische populariteit en ook felle critici, aan de kaak stelt. 


\section{INTRODUCTION}

Public-PrivatePartnerships (PPPs) are usually presented as collaborative inter-organizational relationships between public and private organizations for increasing the efficiency of public infrastructure delivery. Yet, PPPs are realized in very particular long-term contractual engagements, whose effects on the quality of the partnership and its outcomes are often subject to debate by practitioners and scholars. Here it is argued that our understanding of PPPs path at project level requires framing their formal governance structures as continuously (re)shaped by managerial activity, interactions and relations. Project managerial relations and interaction are built upon managers' dual position as members of temporal and permanent organizations. Furthermore, governing managerial activity unfolds within the historically contingent public-private relationing embodied in PPP contracts. Cycles of change and reproduction of PPP governance at the project level emerge, but are not reduced to, the shifts in the control/autonomy relationing in the contested field of public infrastructure and build environment. Therefore, the degrees of managerial freedom or agency depend on their creative enactment of project governance structures and organizational mandates, and their capacity to build new ways of relationing that eventually contribute to change at field level. This PhD dissertation substantiates this idea, taking as an empirical setting the maintenance and operation phase of Design-Build-FinanceMaintenance (DBFM) contracts in the Netherlands. We situate governing activity open to contingency and explainable within the complex process inter-linking agency and structure at project, organization and fields levels. In this introductory chapter, we define PPPs as a governance design and then as a phenomenon. These two different perspectives set up the context that accounts for the need to elaborate on social theory approaches to bring to light the actuality of PPP at the project level. Based on this background, we introduce the problem statement, research questions, approach and strategy inspired in the critical realist logic of scientific discovery. This section ends with the outline of the PhD dissertation.

\section{PUBLIC-PRIVATE PARTNERSHIPS AND GOVERNANCE}

Roads, water, and healthcare are under-provided public goods by the market due to their positive externalities of production. In this situation, the potential benefits of delivering public goods exceed what the private producer can capture (Rangan, Samii, \& Van Wassenhove, 2006). The society might benefit from more and better roads, water systems and hospitals; but private organizations will only provide these to the point they can cover investments with a positive profit margin. Private organizations will also abstain from generating more value due to the absence of guarantees to internalize social gains. Therefore, the government is called to address this market inefficiency, using its authority to re-allocate the costs to beneficiaries and provide public goods. The efficient provision of certain goods such as infrastructure requires capabilities that are difficult to develop in public organizations. The government can provide private organizations economic retribution if they invest their talents and resources in delivering public infrastructure. In other words, the government can 
transfer public responsibilities and risks to the private sector, given the potential efficiencies introduced by private expertise (Kivleniece \& Quelin, 2012). It can also be the case that social value emerges from the complementarity of public-private resources dealing with socio-technical complexity. Urban development requires close collaboration between authorities and the private sector to execute civil works impacting a large range of stakeholders, with strong interdependencies and often conflicting interests. In this case, the government can provide an opportunity for economic gain if private organizations share responsibilities and risks in developing innovative solutions.

By default, such kinds of inter-organizational agreements involve risks for both sides. The future is uncertain, and parties can defeat their initial commitment to creating and distributing value. This is the core of the governance problem in economic thinking and inter-organizational relations (Nooteboom, 1996). Correspondingly, in practice and theory, the nature of PPP has been defined as a governance design of administrative controls and economic incentives to address uncertainty and opportunism leading to efficiency in the delivery of public infrastructure (Yescombe, 2011).

The roots of this very influential idea can be traced back to the seminal work of transaction cost economics, stating that governing activity is a matter of "choosing" a suitable organizational configuration according to the idiosyncrasies of the transaction at hand (Williamson, 1981). A typical infrastructure project involves the delivery of highly specific assets, where partners are exposed to high levels of uncertainty and opportunistic behaviour once they have compromised their resources in a "sunk investment" (Winch, 2010). Then, there is a significant value gap between the current use of resources within the existing transaction and the best alternative use in other transactions, leading to a lock-in relation between partners during the project span (Blanken, 2008). Additionally, the one-off and fragmented process between the phases of design, construction, maintenance and operation increases the difficulty to control outcomes delivered by disparate project teams. (Clegg, Pitsis, RuraPolley, \& Marosszeky, 2002; Henisz, Levitt, \& Scott, 2012; Thompson, 1967). As“nothing can be produced ahead of time [and] a commission always precedes production" (Graafland \& van Liedekerke, 2011, p. 265), contracts typically define responsibilities between clients, contractors, and subcontractors (Bygballe, Håkansson, \& Jahre, 2013; Eccles, 1981).

Contracts constitute a single and temporal organizational arrangement between sovereign organizations (Borys \& Jemison, 1989), taking characteristics of hybrid or quasi-firms that optimize administrative controls and economic incentives for guaranteeing the integrity of the construction project as a transaction (Stinchcombe, 1984). The contracting practice has changed from design and construction agreements to long-term infrastructure contracts, which integrate the entire delivery cycle in one contractual arrangement. These contracts are commonly known as concessional PPPs', defined by the World Bank as "long-term contracts between a private party and a government entity, for providing a public asset or service, in which the private party bears significant risk and management responsibility, and remuneration is linked to performance' (World-Bank, 2014, p.18). Public infrastructure is capital intensive, which implies front-end substantial investments to start the project. Private project sponsors must provide predictable financial flows and clarity of the measures taken for addressing risks and guaranteeing returns on investments. Otherwise, commercial financiers would not provide

${ }^{1}$ Henceforth, the term PPPs refers to concessional PPPs different from alliance-alike PPPs. 
the means for making the project even possible, or they would charge high interest to compensate for risks ${ }^{2}$.

\section{Consequences for the Maintenance and Operation Phases}

The shift from traditional delivery towards PPP implies a change from a focus on asset delivery towards service delivery and output specification. Hence, the private concessionaire is then responsible for the maintenance and operation. The maintenance phase includes the activities aimed to address deterioration and preserve the functionality of the asset within the terms of the life-cycle. The operation phase regards the activities to effectively deliver service, including the day-to-day management of asset components. Examining in detail the logic of PPP brings to light the centrality of operation and maintenance in the arrangement of contractual incentives. In PPPs, the government does not contract the drawings of a road, the construction of bridges, or the execution of asphalt maintenance activities. The government contracts an available road with some safety and quality requirements. Payment depends on road availability or levels of service, providing incentives to think ahead of the consequences for maintenance and operation during the design and construction phases. That is why the operation and maintenance phases are also commonly known as the "exploitation phase" ${ }^{\text {"3 }}$. In other words, project sponsors have the incentive to optimize capital and operational investments for the sake of service delivery.

The pay-offs of PPPs must be assessed in the light of the levels of service and eventual over costs experienced once the building phase is finished. Long-term asset performance requires the controlling of the outcomes from the designing, engineering, and construction phases, traditionally executed by teams with short-term interest to deliver their task irrespectively of their impacts on other phases. In fact, each phase can be considered as a discrete transaction leading to a fragmented process that increases relational risk in the form of displaced-agency (Henisz et al., 2012). This means that the team in charge of a single phase can shift the cost or responsibilities to one or more teams not represented in the current transaction. PPPs bundle the entire lifecycle responsibilities, minimizing the short-term interest to deliver works at expenses of long-term performance. Additionally, PPP contracts bring together private financing and remuneration linked to performance (Dupas, Marty, \& Voisin, 2011; Ménard, 1996). The predictability of financial flows depends on the capacity of private project sponsors to provide evidence that they will deliver the commissioned public service. Unlocking private frontend project financing depends on the predictability of services and, therefore, asset performance during the maintenance and operation phases.

However, in typical 25- or 30-year contracts, initial circumstances and service expectations can change. Therefore, the increasing needs of clients and users during the O\&M phase might alter the initial assumptions supporting designing and building optimizations. This dynamic dimension of PPPS confronting actors to eventual value creation and capture problems during the exploitation phase has been insufficiently explored in the PPP literature (Verweij, Teisman, \& Gerrits, 2017).

\footnotetext{
${ }^{2}$ It is not by chance that the idea that PPPs as governance is strongly embraced by project finance literature (Yescombe, 2011), nor the insistence of development banks that PPPs are innovative governance solutions to address the gap of public financing.

${ }^{3}$ Due to the PPP incentives arrangements, we use "operation and maintenance phase" interchangeably with "exploitation phase" in PPPS.
} 


\section{The Dynamic Nature of Public-Private Partnerships}

The dynamic nature of PPPs not only concerns the possibility of displaced-agency and changes in a single project. It also includes the historically contingent social values embodied in PPP forms that, for the time being, constituted the legitimate way to deal with value creation and capture in publicprivate relations. In fact, interconnections between micro-level and macro-level social mechanisms are fundamental to explain governance dynamic in specific organizational situations (Reed, 2001). PPPs emerged in the UK and Australia during the infrastructure boom, spread to Europe and Canada to deal with the financial crisis and later to the Americas and China to get the economy going in a postcrisis situation (Hodge \& Greve, 2017). PPPs took off in early 2000 in the Netherlands promoted by the government under the motto "Market, unless" in the context of liberalization introduced by European Union directives (Dewulf, Blanken, \& Bult-Spiering, 2012). Additionally, private financing was a solution for addressing the budgetary restrictions of the liberal-social democratic administration confronted with improving public infrastructure (Bult-Spiering \& Dewulf, 2006). The organization of publicprivate relations according to PPP contracting was further legitimized by the ideological principle of "competition is good" in the Netherlands, after a public scandal due to collusion practices (Dorée, 2004; Sminia, 2011). Around the world, PPPs promised policymakers, procurement authorities and market players a win-win situation. On the one hand, it promised mutual safeguards to public clients, private contractors and private financiers by aligning their material incentives along the entire project lifecycle (Grimsey \& Lewis, 2002, 2005). The allocation of risks in a competitive tendering process provided a transparent basis for organizing principal-agent working responsibilities, reinforced by the discipline introduced by lenders. On the other hand, PPPs alleviated public budgetary pressures by bringing forward value-for-money (VfM) in the delivery of public infrastructure. This is the promise of delivering an "optimal combination of quantity, quality, features and price expected over the whole of the project's lifetime" (Burger \& Hawkesworth, 2011, p. 11). However, available empirical evidence shows that VFM is a promise that is neither always assessable nor guaranteed (Arellano-Gault, Demortain, Rouillard, \&Thoenig, 2013; Hodge, Boulot, Duffield, \& Greve, 2017; Hodge, Greve, \& Biygautane, 2018).

First of all, only a few projects can be fully assessed in the light of life-cycle costs because most of them are in their implementation phase (Cui, Liu, Hope, \&Wang, 2018; De Castro e Silva Neto, Cruz, Rodrigues, \& Silva, 2016; South, Eriksson, \& Levitt, 2018). There are scarce insights into the PPP exploitation phase (e.g. operation and maintenance phase), the moment when initial contractual commitments can be contrasted to actual governing activity, collaborative patterns, and contractual changes (Verweij et al., 2017). Furthermore, there is mixed evidence of PPP performance in terms of delivering infrastructure on time and within budget (Hodge \& Greve, 2007; Johnston \& Gudergan, 2007; Van den Hurk \& Verhoest, 2015), satisfying the needs of taxpayers and end-users (Hodge \& Greve, 2010), providing flexibility along the project cycle (Blanken, 2008; Cruz \& Marques, 2013), and satisfactory outcomes according to managerial perception (Verweij, 2015). PPPs are not immune to traditional conflicts due to risk misallocation (Hoezen, 2012), displaced-agency problems (Volker \& Hoezen, 2017), and role ambiguity (Anastasopoulos, Haddock, \& Peeta, 2014).

Beyond organizational forms, the managerial capacity to address emerging issues and continuously re-create the sense of partnership seem to define why some PPPs fail and others do not (Edelenbos \& Klijn, 2009; Klijn, 2008). This means that PPPs are by nature dynamic, and their paths depend on the 
process thought which project actors deal with projects contingencies and unintended consequences from previous project choices (Lenferink, Tillema, \& Arts, 2013; Verweij, 2015). However, existing research on PPP process management mainly takes as empirical reference alliance-alike PPPs rather than concessional PPPs based on contractual forms (Klijn, Edelenbos, \& Hughes, 2007). We have a poor understanding of contingency in concessional PPPs, and it remains unclear how contractual forms are modified or re-created by managers when addressing project issues.

On the other hand, some researchers have pointed out that PPP programs are usually misaligned to the institutional and social context (Matos-Castaño, Mahalingam, \& Dewulf, 2014; South et al., 2018). Furthermore, PPP development and outcomes at the project level are necessarily contingent upon the policy struggles and political contexts (Hodge et al., 2017; Hodge \& Greve, 2017). In particular, PPPs manifest the shift towards efficiency as the core private value in the policy discourse and practices, claiming that VfM is a political-free criterion to assess and solve eventual trade-offs between efficiency and effectiveness (Arellano-Gault et al., 2013) ${ }^{4}$. The point made by Hodge and Greve (2017) is that a PPP is "as much a political entity as it is a procurement or managerial entity, and decision making and choices are part of the fabric of the Western democratic process" (Hodge \& Greve, 2017, p. 66). PPPs cannot be reduced to neutral instruments to govern an economic transaction between public and private organizations from the perspective of efficiency. PPP contractual formal arrangements render the legitimate ways for organizing the delivery of public infrastructure for the time being of their tendering phase. However, policy values can change, transforming what is considered a legitimate public-private interaction during the execution of a typical PPP year contract for 25 or 30 years. The interface between the changing policy context and PPP project dynamics cannot be captured by traditional approaches to project management.

\section{THE TURN-TO-SOCIAL THEORY FOR STUDYING PROJECTS AS THEY ACTUALLY ARE}

As the PPP literature has insufficiently accounted for the PPPs' micro and macro dynamics, likewise, project management literature has overlooked how projects evolve the way they do. Traditionally, projects have been regarded as temporal and relatively autonomous systems composed of a team tasked to perform activities towards a pre-agreed objective in a specific context (Lundin \& Söderholm, 1995). In inter-organizational projects, the suitability of ex-ante collaborative designs ultimately relies on the governance structure that temporarily bound organizations together based on control or trust mechanisms (Sydow \& Braun, 2017). Control mechanisms increase predictability by limiting the number of possibilities to be taken into account by actors, while trust mechanisms reduce complexity by discarding the eventual negative state of the system based on the expectation that the performers refrain from opportunistic behaviour (Edelenbos \& Eshuis, 2012; Teisman, van Buuren,

\footnotetext{
${ }^{4}$ Efficiency is only one side of the double production function characterizing organizing activity in public domains (Arellano-Gault et al., 2013). While efficiency refers to internal organizational administration to link resources to outputs from a purely economic point of view, effectiveness refers to external policy management to assess the impacts according to social (and therefore contested) legitimacy.
} 
\& Gerrits, 2009). Therefore, their interplay can be "symbiotic" or "interferential". The former reinforces the relationship between trust and control, whereas the latter weakens it (Poppo \& Zenger, 2002; Teisman et al., 2009). Control and trust are functional equivalents with potential trade-offs which have to be carefully optimized for engineering collaboration and success. In the adversarial construction industry, informal governance mechanisms are usually regarded as functional complements for engineering collaboration by means of relational contracting (Bresnen \& Marshall, 2002; Lahdenperä, 2012).

However, it was particularly insightful observing that civil engineering projects structured according to project management guidelines for success turned into a failure, in comparison to those successful ones relying on less structured ways of project organizing (Engwall, 2003). Additionally, practice showed that governance structures defined at the front-end of projects are continuously challenged during project execution, and usually fail to address contingency (Sanderson, 2012). These observations bring to light that traditional project management literature reduces projects "as a distinct, manageable activity system that, once designed using the proper schedule techniques, can be isolated from the environment" (Blomquist \& Packendorff, 1998, p. 38). This widespread belief in project management is grounded in engineering and economist approaches to social systems, which reduce projects to tools and temporally closed systems at the will of project designers (Winter, Smith, Morris, \& Cicmil, 2006). Functionalistic and economic approaches are by nature normative traditions of thinking, which purposefully overlook the complexity of projects as open systems to predict their functionality.

In this regard, the main insight brought by social theory is that organizing processes never go exactly according to plan as sanitized texts on organizational behaviour assume (Cooper, 1990; Fineman, Gabriel, \& Sims, 2009). Project governance cannot be reduced to a set of technical and economic designs aiming to provide incentives for performance. The turn-to-social theory for studying projects is an opportunity for bringing to light the complex nature of PPPs and their governance dynamics at project level open to agency creativity and situated in social contexts. While promising to capture why PPP projects evolve the way they do during their O\&M phase, social theories remain unexplored in project management (Floricel et al., 2014).

\section{Project Governance, Agency and Structure}

Social theory seeks to explain order and looks at how human activity is shaped, but it also transforms the world people inhabit (Archer, 1995). Therefore, the key to account for the complexity and dynamics of governance in organizational situations is the nature of and link between human activity and its social contexts (agency-structure interplay) (Reed, 1997). By aiming to capture this interplay, organizational scholars with a strong sociological background provide a situated and contingent perspective of project governance and activity. Their standpoint openly contrasts to the sanitized biases of engineering and economist lenses of project governance, which overestimate the functional predictability of ex-ante organizational designs. Yet, social theory is - by no means - a homogeneous tradition of thinking but includes a rich system of ideas characterized by strong and unresolved ontological and epistemological debates (Archer, 1995; Bhaskar, 1998). Accordingly, sociological-based approaches to project governance have framed project dynamics and complexity, privileging one standpoint to explain why projects are organized in the way they are. 
Sociological institutionalism privileges the structural standpoint according to which projects are governed by regulative, normative and cognitive pillars defined by social contexts (Henisz et al., 2012; Scott, 2013). These three institutional pillars are shared systems of meaning which make human behaviour "regularized" according to the situation or context. The regulative pillar includes formal scripts of behaviour that are susceptible to be enforced by authority or price-incentives. The normative pillar defines appropriate behaviour according to the symbolic exchange process susceptible to being socially sanctioned. The cognitive-cultural pillar provides conceptual frameworks and shared identities, aligning values or interests. Even when collaboration cannot be engineered, this branch of the literature suggests that normative and cognitive pillars can be manipulated to support relational contracting (Henisz et al., 2012). Recently, this statement has been moderated indicating that "through practice [formal structures such as the contract] are negotiated and adjusted as the partners jointly and gradually make sense of the work and the relationships" (Bygballe, Dewulf, Levitt, Carrillo, \& Chinowsky, 2013). The process of sense-making is supported by the existence of diverse and longlasting institutional pillars, providing a system of shared meanings.

The relevance of managerial agency is stronger in the European call for accounting for the complex relationship between project practices and social construction of reality (Svejvig \& Andersen, 2015). This standpoint has informed the British Rethinking Project Management initiative (Winter et al., 2006), the Scandinavian school of project studies (Sahlin-Andersson \& Söderholm, 2002), and practice studies school (Blomquist, Hällgren, Nilsson, \& Söderholm, 2009). They argue that traditional governance thinking is based on the notion of actor farsightedness, ignoring that project reality is socially constructed and that the future is inherently unpredictable (Sanderson, 2012). Most of the time, the future has little or no relation to present conditions or past experiences. Therefore, it can be irrelevant preparing for the future before it has happened. Instead, Sanderson (2012) argues that research should take more seriously the micro-practices of spontaneous governing. In particular, it should be noticed that "project governing, like the project itself, only exists by praxis drawing upon certain practices" (Sanderson, 2012, p. 440). Engineering and economic thinking disregard the centrality of "activity" as the actual stuff that project governance is made of. Therefore, they downplay or ignore that activities of governing might (re)create the forms of governance. This argument has been elaborated upon the practice ontology of structuration theory (Giddens, 1984; Nicolini, 2013), according to which actors organizing the temporal project bring selectively into play (and re-shape) the structural properties of permanent contexts (Sydow, Lindkvist, \& DeFillippi, 2004).

Institutional and practice-oriented approaches to project governance aim at providing understanding project dynamics as the way they are, framing their actuality in the agency and structure debate. Institutionalism in organizational studies overcomes the pretention to understand governance mechanisms abstracted from their contexts, recognizing the existence of diverse systems of shared meaning, a source of legitimate behaviours operating as structures. Practice-oriented theories allow overcoming the static bias of a functionalist and economist analysis of control and trust relations, underlying contingency and the creative powers of managers. Nevertheless, both approaches fail to recognize that agency and structure are existentially interdependent but essentially distinct (Reed, 1997). The far-reaching nature of institutional pillars subordinate trust and activity to the stable structures of shared meaning in a sort of determinism, blurring the role of agential powers and change (Mutch, 2018a; Reed, 2001). On the other hand, the voluntarist bias of practice approaches leads to 
overrating actors capacity to manipulate control and trust relations at their will, negotiating some form of a temporary social order where trust is independent of constraints (Cruickshank, 2007; Reed, 2001). Therefore, project studies lack an approach that frames governance structure and governing activity dynamics consistently to the vexatious facts of open social systems (Archer, 1995). Namely, that the authenticity human experience - including project actors - is that we are both free and constrained (see Archer, 1995, p. 29).

\section{PROBLEM STATEMENT}

Existing Public-Private Partnerships (PPP) governance approaches rely on the front-end design of organizational structures and decision-making procedures to guarantee the integrity of value co-creation and capture. However, the practice shows that designing governance structures is a necessary condition to constitute PPP projects, but it rarely determines their outcomes and actual implementation. Related to this practice problem, research has extensively focused on the frontend process of crafting of PPP governance structures. However, there are few insights into why PPP projects evolve in the way they do. PPP project teams face multiple demands attached to the original commitment, and emerging demands endogenous to project paths and exogenous from changing contextual circumstances. Their governing activity can re-create the partnership and the initial ways of PPP organizing, yet project actors are constrained by governance structures meant to shape behaviours according to policy values that are historically contingent. The complex dynamic nature of PPP depending on micro-and-macro drivers of social and organizational change should come forward, as its research is insufficient.

In particular, we have little knowledge into the extent to which initial PPP agreements evolve as they do when exposed to contingency, managerial activity and change during their maintenance and exploitation phase (Verweij et al., 2017). The actuality of PPP projects cannot be captured by normative approaches grounded on engineering and economic thinking because they disregard the nature of PPPs projects as open systems. Social theories provide an opportunity to account for the dynamics of PPP project level beyond expected behaviours shaped by front-end contractual designs and economic incentives. The turn-to-social theory situates PPP contracts and dynamics as an emerging phenomenon, stemming from the agential capacity at the project level to shape project paths constrained and dependent to socio-political processes. Yet, existing sociological-oriented approaches in project management leads to either structural determinism or agential voluntarism. They fail to do justice to the nature of and link between human activity and its social contexts in studying governance and PPP projects, overlooking that agency and structure are existentially interdependent but essentially distinct. Accordingly, this PhD dissertation aims to answer the following main question: 


\section{How do managerial agency and project governance structures rely on and re-shape each other during the O\&M phase of PPPs?}

This dissertation structures four specific questions to guide the research towards the main question.

1. What is the relationship between governance mechanisms, managerial coordination, and performance in PPP projects?

2. How can PPP governance be conceptualized as agency/structure interplay at the project level?

3. How does managerial activity unfold in relation to project structures during the O\&M phase of PPPs, in a dynamic organizational and field context?

4. How do practitioners reflect on their managerial agency in the implementation of PPP projects?

\section{RESEARCH APPROACH}

This PhD dissertation is inspired by the logic of scientific discovery of the Critical Realism approach (AlAmoudi \& Willmott, 2011; Bhaskar, 1997, 1998; Cruickshank, 2007). In general, critical realists embrace ontological boldness by avoiding epistemic and genetic fallacies in their research practice (Bhaskar, 1997; Cruickshank, 2007). The epistemic fallacy reduces what exists to how we may know the world and, by doing so, reality to what the researcher can know. By overlooking this fallacy, positivist tradition makes the questionable claim that they have direct access to the "true" and their empirical experience is a direct mirror of reality. On the other hand, the genetic fallacy reduces the reality to a matter of what we can know via our perspective. By overlooking this fallacy, constructivist and postmodernist traditions make the questionable claim that truth depends on a conceptual scheme rather than an extra-discursive reality. All understandings of the word are inevitably conditioned from one standpoint (epistemological relativity). Yet, critical realists believe in the existence of an external reality which cannot be reduced to our interpretations.

Major contributors to Critical Realism claim that better conceptual accounts of observed phenomena require an ontological commitment whose definition should depart from what intellectual opponents are willing to share (Al-Amoudi \& Willmott, 2011). For studying PPP governing activity as social phenomena, we believe that most of our contenders agree with us that "the authenticity of the human experience [is] that we are both free and constrained" (Archer, 1995, p. 29). Therefore, the point of departure in this research is avoiding conflation of agency and structure leading to voluntarism or structural determinism. In consequence, the value of empirical research in PPPs is validating/refining the existing theoretical approaches to account for observable governing activity, causally dependent on [not-directly] observable mechanisms emerging from the agency-structure interplay (Archer,

\footnotetext{
${ }^{5}$ Accepting that reality exceeds what we can know leads to a stratified vision of reality in an open system comprised of three hierarchical strata (Bhaskar, 1997). There is a non-observable ontological domain (the domain of the real) that furnishes the domain of the actual. In turn, the domain of the actual furnishes the domain of the empirical. The ontological domain is comprised of "generative mechanisms" or "structure at work", which are "nothing other than ways of acting of things" (Bhaskar, 1997, p. 33). The domain of the actual regards the strata where observable events take place, emerging from the ontological domain. The empirical domain refers to the experiences captured by the researcher/observer from the domain of the actual. In short, "phenomena emerges from mechanisms that operate at one level of existence but, once emergent, cannot be reduced back to those mechanisms" (Mutch, 2018b).
} 
1995; Karlsson \& Ackroyd, 2014). In other words, the critical realist research approach is necessarily a theoretically driven scientific endeavor.

\section{RESEARCH DESIGN}

The research design is influenced by the logic of scientific discovery/explanation of Critical Realism, known as retroduction. Retroduction is a mode of "inference in which events are explained by postulating (and identifying) mechanisms which are capable of producing them" (Sayer, 1992, p. 107). In answering the main question, we aim to collect events of contractual project activity and episodes of working interactions in executing PPPs. These events are produced by mechanisms operating in the project, organizational and field contexts. As these mechanisms are not directly observable, we follow the three stages of the retroductive cycle for bringing to light the nature of these mechanisms (see Figure 1). The first stage is identifying a regularity according to classical empiricism and the prevailing theory in a scientific field based on initial observation. The second stage is imagining how the world must be to make this regularity possible, based on a clear ontological point of departure in dialogue with existing theoretical knowledge. The realist ontological commitment in the domain of social theory applied to project governance existing knowledge is that agency and structure are existentially interdependent but essentially distinct (Reed, 2001). The third stage is bringing new empirical data in the light of the postulated causal mechanism in accounting for governing events and path of governing activity (sequences and invariances). This stage aims to account for how the mechanism operates (or abstains from operating) due to contexts and other mechanisms.

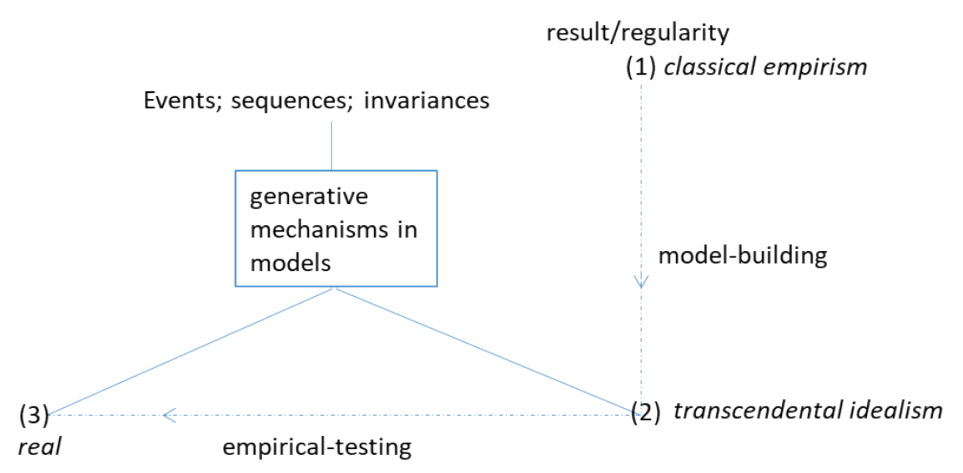

Figure 1 Logic of scientific discovery according to Critical Realism (Bhaskar, 1997, p. 44)

Accordingly, the research design involves three stages. The first stage operates at the empirical level, establishing a regularity between the operation of PPP governance mechanisms and performance. The theoretical relations tested are informed by the neo-institutional economic understanding of contractual and relational governance operating as the mainstream theory in inter-organizational relations (Poppo \& Zenger, 2002). The empirical setting is given by managerial perceptions in known PPP projects in the Netherlands. This is a cross-sectional design for testing moderators and mediating 
effects intervening in the impact of contractual PPPs governance and performance. At this initial stage, governance is defined as a behavioural and static mechanism according to the prevailing theory in a scientific field. Now, the critical realists' concern is not searching for explanations in terms of regularities between observable events. Realists make a distinction between the causal mechanism and its causal effects. A causal mechanism can exist, but its powers might not be materialized in an event due to the existence of multiple mechanisms operating in a specific context. Yet, critical realists do run regressions ${ }^{6}$. "What statistical analysis can do is examine where and how generally such mechanisms operate" (Porpora, 2001, p. 49). In our research design, the regularity at the empirical level is taken as a cue for exploring the nature of PPP project governance mechanisms in the Netherlands. As the mainstream theory operates at the level of the empirical, it cannot capture how the mechanisms are configured in deeper (and non-directly observable) levels or reality. These levels of reality regard the agency-structure interplay, which can be (fallible) accessed by consistent re-theorization of existing knowledge (Stage 2) and further empirical testing taking a specific socio-historical context (Stage 3).

Accordingly, the identified regularity is re-framed in the second stage in a process framework based on our ontological point of departure (agency and structure) and theoretical literature on PPPs and project governance. In other words, we re-frame the nature and operation of behavioural and static governance mechanisms as observable events emerging from the agency-structure interplay at the project level. Within this process framework, we postulate a non-directly-observable explanatory mechanism in terms of project/organizational structural predispositions shaped in the past, and mediated by managerial agentic power in the present. We illustrate the operation of the non-directlyobservable mechanism in the process framework, explaining one episode of managerial interaction dealing with contractual complexity in the exploitation phase of a Dutch PPP. In the third stage, the postulated explanatory mechanism is examined first in a comparative case research design, and then in a serious game setting. The comparative research design brings to light how paths of governing activity (single events, sequences and invariances within and between cases) can be explained by the postulated mechanism contingently operating in specific operational and policy contexts. Finally, the serious game setting aims to emulate the postulated mechanism in a controlled setting, to reflect with practitioners on its existence and operation in their working life as open systems (reality).

\section{Step 1 - Interplay of relational and contractual governance in PPPs: the mediating role of relational norms, trust and partners' contribution}

This step helps to answer our first research question: What is the relationship between governance mechanisms, managerial coordination and performance in PPPs projects?

In Chapter 1, we adopt the prevailing perspective of inter-organizational governance derived from neo-institutional economics, stating that contractual and relational governance are discrete and static mechanisms leading to performance (Poppo \& Zenger, 2002). In particular, we test the overlooked proposition that formal mechanisms define the blueprint of behaviour, and informal mechanisms

\footnotetext{
${ }^{6}$ "In the end, there are no specifically CR methods of research. Unlike both positivism and Interpretivism, CR does not pose an opposition between qualitative and quantitative methods. It specifically does not just reverse what is included and excluded. To do so would erect a new methodological foundationalism. Instead, CR reunifies sociological methodology. From a CR perspective, there is a valid and important place for all of the methods sociologists have employed - although not necessarily in the way they have employed them. Statistics, as mentioned, should function as a form of evidence for an explanation rather than as an explanation itself" (Porpora, 2001, p. 64)
} 
mediate their impact on actual behaviours (Zenger, Lazzarini, \& Poppo, 2000). This study uses a confirmatory theory testing approach based on updated Structural Equation Modeling - Consistent Partial Least Squares (SEM-PLSC) guidelines to validate our theoretical model by assessing the overall fit of the model (Henseler, Hubona, \& Ray, 2016). Data was collected through a survey of private and public managers involved in officially known PPP projects in the Netherlands ( $n=157$ ), in a collaborative effort with the research partners of the program financing this $\mathrm{PhD}$. As was explained, empirical testing is only a first research step for postulating causal mechanisms operating in deeper levels of social reality defined by the agency-structure interplay in a specific historical context.

\section{Step 2 - Contractual and relational governance as positioned-practices in ongoing PPPs}

This step helps to answer the second research question: How can PPP governance be conceptualized as agency/structure interplay at the project level?

In Chapter 2, we re-frame the results obtained in the first stage in terms of activity unfolding as a complex process linking agency and structure overtime at the project level. The framework of reference is the so-called morphogenetic approach (Archer, 1995). Morpho indicates shape and genesis indicate that "the shaping" is the result of agents' activity; linking agency and structure in cycles of change or reproduction. We engage a theoretical dialogue between Archer (1995), the literature on private and public organizational logics (e.g. Rufín \& Rivera-Santos, 2012), and the multilevel view of project governance (Ahola, Ruuska, Artto, \& Kujala, 2014; DeFillippi \& Sydow, 2016; Turner \& Müller, 2003). The resulting sui-generis morphogenetic cycle at project level situates observable governing activities as practices granted to managers by their dual position, as members of a temporal contractual relation and part of permanent organizations. We postulate as a non-directly-observable explanatory mechanism the creative managerial mediation of the demands imposed by their dual position. We took the path of governing activity of a DBFMO project in the Netherlands to illustrate how governing activity emerges from the point of contact between agential reflexivity and project/organizational structures. The research design followed the principles of action research (McKay \& Marshall, 2001). Our task was supporting knowledge transfer from the studied case to the wider practitioners' network on changes in the scope of DBFMO projects during the exploitation phase. The methods included interviews and building together with managers Causal Loop Diagram of their working processes (Vennix, 1996).

\section{Step 3 - Governance of temporary organizing in the changing field of PPPs}

This step helps us to answer the third research question: How does managerial activity unfold in relation to project structures during the O\&M phase of PPPs, in a dynamic organizational and field context?

Chapter 3 focuses on how managers attend multiple demands due to their dual position in the exploitation phase of PPPs and examines to which extent initial project governance structures remain stable in a changing context (Söderlund \& Sydow, 2019; Windeler \& Sydow, 2001). It compares the governing paths of three DBFM projects in the Netherlands by recalling narratives of inter-organizational collaboration and contractual activity. The cases were selected-for-difference (Kessler \& Bach, 2014). The three projects were procured in different "waves" of PPP adoption in the Netherlands. These waves refer to different procurement policies to transfer project risk to the market, as well as different discourses 
on public-private collaboration (Koppenjan \& de Jong, 2018; Matos-Castaño et al., 2014). In selectingfor-difference, the "divergence in process and outcomes" gives insights that structural and institutional features prevail over agency in the selected cases. On the contrary, if there is a convergence in the process and outcomes, it would suggest a greater scope for agency. After establishing divergence or convergence in cases, each case is approached according to the exploratory case study in Critical Realism (Vincent \& Wapshott, 2014) and the relational realist principles for researching morphogenetic cycles (Donati, 2017). The expectation is accounting for the managerial agency role and their structural conditionings in the reproduction and change of the project governance structure, taking as a reference their historical procurement moment and contextual changes. This stage of the research allows us to bring additional empirical data to examine how the non-directly-observable explanatory mechanism postulated in the second stage operates in a specific operational and policy context.

\section{Step 4 - The "3P challenge": reflecting on the sense of partnership in public-private concessions}

This step helps us to answer the fourth research question: How do practitioners reflect on their managerial agency in the implementation of PPP projects?

In Chapter 4, we introduce the serious game "3P challenge" as a vehicle to reflect with practitioners on their working relationships during the exploitation phase of PPPs. The game design is based on the insights from the analytical research cycle, aiming at activating participants' reflexivity to consider the diverse demands they face as project managers (Donati, 2010). Accordingly, the game emulates tendering invitations at market level interacting with the outcomes of the projects awarded, supported by a system dynamic simulation for representing asset life-cycle. Players are embedded in a gaming experience shaped by a controlled setting as an invitation to reflect on their interaction structured according to the postulated process mechanism in the closed system (game) and the open system (practice). The game was played in two sessions in the Netherlands, one with a mixed group of infrastructure professionals including some PPPs experts and another one with a team of PPPs public contract managers. This research stage allows us to co-create knowledge with practitioners to reflect on the existence and operation of managerial agency as part of the postulated mechanism operating in operating in the Dutch context. 


\section{THESIS OUTLINE}

The layout of this study is schematized in Table 1. In this table, the guiding research questions are linked to the research steps, the corresponding stage in the critical realist logic of discovery/ explanation, methods used and chapters. The two initial chapters have been published in academic journals in the field of project management, while the other two have been submitted to relevant scientific publications in the field of organizational studies. We clarify the status of the publications in the introduction of the chapters. Chapter 1 presents the statistical analysis testing the empirical relation between governance mechanisms and satisfactory performance in PPPs. Chapter 2 re-frames the conceptualization of governance mechanisms as governing activity in cycles of governance structure reproduction, following critical realist sociology and the prevailing multilevel view of project governance. Chapter 3 compares three DBFM projects in their exploitation phase, accounting for the (re) reproduction of their front-end structures in the changing field of PPPs in the Netherlands. Chapter 4 introduces the " $3 \mathrm{P}$ challenge" as a serious game serving as a vehicle to reflect with Dutch practitioners about their governing activity from the standpoint conceptualization developed in this thesis. In Chapter 5, we consider the answer to all sub-questions in order to address the steering question of this research. In this final chapter, we further discuss our theoretical and practical contribution, as well as limitations and further opportunities for research. 
Table 1 Layout of this study is schematized

\begin{tabular}{|c|c|c|c|}
\hline $\begin{array}{l}\text { Stages of the logic of } \\
\text { scientific explanation/ } \\
\text { discovery }\end{array}$ & $\begin{array}{l}\text { Guiding research } \\
\text { questions }\end{array}$ & Research steps & $\begin{array}{l}\text { Chapters and methods } \\
\text { used }\end{array}$ \\
\hline $\begin{array}{l}\text { Identifying a regularity } \\
\text { according to classical } \\
\text { empiricism and prevailing } \\
\text { theoretical terms }\end{array}$ & $\begin{array}{l}\text { RQ1: What is the } \\
\text { relationship between } \\
\text { governance mechanisms, } \\
\text { managerial coordination, } \\
\text { and performance in PPP } \\
\text { projects? }\end{array}$ & $\begin{array}{l}\text { Step 1: Testing the } \\
\text { empirical relationship } \\
\text { between contractual } \\
\text { and relational aspects of } \\
\text { governance according } \\
\text { to neo-institutional } \\
\text { economics }\end{array}$ & $\begin{array}{l}\text { Chapter 1: Survey of } \\
\text { research }(n=157) \text { of } \\
\text { PPP managers in the } \\
\text { Netherlands and the use } \\
\text { of Partial Least Square } \\
\text { - Structural Equation } \\
\text { Modeling }\end{array}$ \\
\hline $\begin{array}{l}\text { Imagining how the world } \\
\text { must be to make this } \\
\text { regularity possible, based } \\
\text { on a sound ontological } \\
\text { point of departure in } \\
\text { dialogue with existing } \\
\text { theory }\end{array}$ & $\begin{array}{l}\text { RQ2: How can } \\
\text { governance mechanisms } \\
\text { and their relations be } \\
\text { conceptualized as a } \\
\text { complex social activity in } \\
\text { ongoing PPPs? }\end{array}$ & $\begin{array}{l}\text { Step 2: Re- } \\
\text { conceptualizing } \\
\text { governance mechanisms } \\
\text { and their relationship } \\
\text { as a complex process, } \\
\text { avoiding voluntarism or } \\
\text { determinism }\end{array}$ & $\begin{array}{l}\text { Chapter 2: Realist social } \\
\text { theory in dialogue with } \\
\text { the multilevel view of } \\
\text { project governance. } \\
\text { Illustrative case in an } \\
\text { action research setting, } \\
\text { supported by Group } \\
\text { Model Building }\end{array}$ \\
\hline $\begin{array}{l}\text { Bringing new empirical } \\
\text { data in the light of } \\
\text { the imagined causal } \\
\text { mechanism, accounting } \\
\text { for events, sequences and } \\
\text { invariances for a specific } \\
\text { context }\end{array}$ & $\begin{array}{l}\text { RQ3: How does } \\
\text { managerial activity } \\
\text { unfold in relation to } \\
\text { project structures during } \\
\text { the O\&M phase of PPPs in } \\
\text { a dynamic organizational } \\
\text { and field context? }\end{array}$ & $\begin{array}{l}\text { Step 3: Examining how } \\
\text { managers attend multiple } \\
\text { demands and to which } \\
\text { extent the initial project } \\
\text { governance structure } \\
\text { remains }\end{array}$ & $\begin{array}{l}\text { Chapter 3: Comparative } \\
\text { cases selected-for- } \\
\text { difference according } \\
\text { to PPP policy and } \\
\text { supported by narrative } \\
\text { analysis and contractual } \\
\text { documentation }\end{array}$ \\
\hline $\begin{array}{l}\text { Engaging practitioners } \\
\text { with the scientific } \\
\text { perspective developed in } \\
\text { this research for exploring } \\
\text { the operation of the } \\
\text { casual mechanism }\end{array}$ & $\begin{array}{l}\text { RQ4: How do } \\
\text { practitioners reflect on } \\
\text { their managerial agency } \\
\text { in the implementation of } \\
\text { PPP projects? }\end{array}$ & $\begin{array}{l}\text { Step 4: Reflecting with } \\
\text { practitioners on their } \\
\text { interaction in the closed } \\
\text { system (game) and the } \\
\text { open system (practice). }\end{array}$ & $\begin{array}{l}\text { Chapter } 4 \text { : Serious game } \\
\text { supported by system } \\
\text { dynamics simulation } \\
\text { and played with PPP } \\
\text { practitioners in two } \\
\text { sessions }\end{array}$ \\
\hline $\begin{array}{l}\text { Validating/refining the } \\
\text { existing theoretical } \\
\text { hypotheses to account } \\
\text { for observable } \\
\text { phenomena, causally } \\
\text { dependent on } \\
\text { mechanisms that are not } \\
\text { directly observable }\end{array}$ & $\begin{array}{l}\text { Central question: How } \\
\text { do managerial agency } \\
\text { and project governance } \\
\text { structures rely on and re- } \\
\text { shape each other during } \\
\text { the O\&M phase of PPPs }\end{array}$ & & $\begin{array}{l}\text { Chapter 5: Conclusions } \\
\text { and discussion }\end{array}$ \\
\hline
\end{tabular}




\begin{tabular}{l} 
INTERPLAY OF RELATIONAL AND \\
CONTRACTUAL GOVERNANCE IN \\
PUBLIC-PRIVATE PARTNERSHIPS: \\
THE MEDIATING ROLE OF RELATIONAL \\
NORMS, TRUST AND PARTNERS' \\
CONTRIBUTION \\
\hline
\end{tabular}

\section{ABSTRACT}

Defining the nature of the relationship between contractual and relational governance is critical for understanding how to maintain commitment and coordination between private and public organizations in long-term partnerships. In this study, a theoretical model explains Public-Private Partnership (PPP) project performance as the result of a mediation process. Contractual and relational governance elements operate sequentially with relational elements (relational norms and trust), playing a mediating role between contractual elements, project actors' behaviour and final performance. Based on the analysis of a survey of PPP practitioners in the Netherlands, and using Consistent Partial Least Squares Modelling, the study provides empirical support for these mediating effects. The findings are aligned with the idea that both economic incentives and hierarchical relationships formalized in contract agreements require being internalized in working practices by means of informal and socially based mechanisms. The enabling and compensating mechanisms underlying the mediation role of relational governance elements are discussed. Managers can particularly find in relational norms a leverage point for designing collaborative day-to-day practices aimed at reinforcing trust and longterm contractual obligations.

Keywords: Public-Private Partnerships - Contractual Governance - Relational Governance -Project Governance - Trust - Relational Norms - Partners' Contribution

${ }^{7}$ Published as: Benítez-Ávila, C., Hartmann, A., Dewulf, G., \& Henseler, J. (2018). Interplay of relational and contractual governance in public-private partnerships: The mediating role of relational norms, trust and partners' contribution. International journal of project management, 36(3), 429-443. 


\section{$1.1 \quad$ INTRODUCTION}

Public-Private Partnership (PPP) projects have gained increasing popularity for organizing the economic transaction between public and private organizations in the provision of public infrastructure and other public assets (Boardman, Greve, \& Hodge, 2015; OECD, 2012, p. 194). Nevertheless, existing literature suggests that establishing innovative contractual forms of economic exchange between the public and the private sector does not automatically lead to improved performance. There is mixed evidence of the performance of PPPs in terms of delivering infrastructure on time and budget (Hodge \& Greve, 2007, 2010, 2017; Van den Hurk \& Verhoest, 2015), satisfying the needs of taxpayers and end-users (Hodge \& Greve, 2010), providing flexibility along the project cycle (Blanken, 2008; Cruz \& Marques, 2013), and providing satisfactory outcomes according to the perception of public and private managers (Verweij, 2015). PPP is not a magical contractual recipe to overcome typical governance problems of projects such as displaced agency, and their one-off, uncertain and highly asset-specific nature (Levitt, Henisz, \& Settel, 2009). Furthermore, diverse levels of performance within similar contractual arrangements have brought up the relevance of idiosyncratic practices that are difficult to imitate between PPP projects, given their dependence on social, personal and informal relations (Bresnen \& Marshall, 2002; Gibbons, 2010).

Contractual and relational governance are considered as different governance mechanisms for triggering cooperative efforts to array project processes leading to performance and value for stakeholders (Levitt et al., 2014; Roehrich, 2009; Zheng, Roehrich, \& Lewis, 2008). It is particularly the interplay between contractual and relational governance that has gained much attention and discussion in the study of inter-organizational arrangements (Cao \& Lumineau, 2015; Poppo \& Zenger, 2002). The original terms of the debate were defined by Poppo and Zenger (2002), who framed the contractual and relational governance interplay as a dichotomy between complementarity and substitution. Since then, scholars have researched the interplay to understand whether complementarity or substitution impacts on inter-organizational performance. The outcomes of these studies are not conclusive. For example in project management studies assessing "technical" and "Edgeworth" definitions of complementarity (Cao \& Lumineau, 2015) 8, "Edgeworth" complementarity has been supported for R\&D projects (Arranz \& Arroyabe, 2012), software development projects (Gopal \& Koka, 2012), and construction projects (H. Ke, Cui, Govindan, \& Zavadskas, 2015; Lu, Guo, Qian, He, \& Xu, 2015), and "technical" complementarity has been found in R\&D projects (Ryall \& Sampson, 2009) and construction projects (Lu et al., 2015). However, there is also evidence for "Edgeworth" substitution in the exploration phase of R\&D projects (Olander, Hurmelinna-Laukkanen, Blomqvist, \& Ritala, 2010) and non-equity project alliances (Lui \& Ngo, 2004). Given the existence of these inconsistent findings, it has been suggested that a more fruitful endeavor is the investigation of "how" and "when" relational and contractual governance interact in relation to project performance rather than striving for a definitive answer to "what" is the interplay (Cao \& Lumineau, 2015).

In this context, the objective of this paper is providing a more fine-grained analysis of the interaction between contractual and relational governance in Public-Private Partnership (PPP) projects. More

${ }^{8}$ While technical definition focuses on the mutual relation between two variables (e.g. the increase of trust encourages the increase of contractual governance), Edgeworth focuses on the joint impacts of two variables in a third one (e.g. raising trust increases the returns to raising contractual governance for increasing project performance). 
specifically, this chapter intends to propose and test a theoretical model that explains PPP project performance as the result of a mediation process. There, contractual and relational governance elements operate sequentially with relational elements (relational norms and trust) playing a mediating role between contractual elements, project actors' behaviour and final performance. This consistent model is based on an overlooked proposition from seminal neo-institutional theory (Zenger et al., 2000), according to which "formal institutions define the normative system designed by management or the blueprint for behaviour, [while] informal institutions define the actual behaviour of players" (Zenger et al., 2000, p. 55).

The chapter contributes to the ongoing debate on contractual/relational interplay by redirecting the discussion from the prevalent substitution/complementarity dichotomy to a sequential conceptualization along chains of mediated causality. Additionally, it also provides quantitative supporting evidence for PPP projects, where previous research has mainly used qualitative research strategies for addressing the contractual/relational interplay in PPPs (Bygballe, Dewulf, \& Levitt, 2015; Hartmann, Davies, \& Frederiksen, 2010; Rufín \& Rivera-Santos, 2012; Strong \& Chhun, 2014; Zheng et al., 2008) with few exceptions (Z. Zhang, Wan, Jia, \& Gu, 2009). The proposed theoretical model is empirically validated by means of Consistent Partial Least Squares Structural Equation Modelling (PLSC-SEM), assessing the overall fit of the model for estimating measurement and structural model misspecification (Henseler et al., 2016). This validation is absent in the current literature examining the interplay of contractual and relational governance elements by means of SEM-PLS (Goo, Kishore, Rao, \& Nam, 2009; Lu et al., 2015) making these studies and the obtained results rather exploratory in nature. However, the scope of the paper is limited to the interplay of governance elements at PPP project level, excluding the wider institutional, cultural and policy context that may affect governance approaches. Furthermore, the empirical evidence is cross-sectional which cannot account for any feedbacks over time between the different elements studied.

The chapter is organized into four main sections. It starts off with the conceptual background, the introduction of the theoretical model and the related research hypotheses. In the second section, the research design is presented. It consists of a survey of private and public managers involved in PPP projects in the Netherlands as data collection approach, and PLSc-SEM as data analysis method. The third section presents the results of the data analysis, which support the mediating role of relational governance elements in PPP projects. In the fourth section, the findings are discussed reframing the substitution/complementarity debate in the light of mediation analysis and process mechanisms (enabling/compensating). This section also includes managerial implications and limitations of the study. The chapter ends with some concluding remarks. 


\subsection{CONTRACTUAL AND RELATIONAL GOVERNANCE IN PPP PROJECTS}

The World Bank defines PPP as a "long-term contract between a private party and a government entity, for providing a public asset or service, in which the private party bears significant risk and management, and payment is linked to performance" (World-Bank, 2014, p. 19). This conceptualization ascribes to PPPs a particular set of formal rules with the capacity to ensure the delivery of public goods and services by defining obligations, roles and mission of a temporal coalition (Bygballe, Håkansson, et al., 2013). However, contracts are only binding promises to act in the future under the expectation of value creation (Scott \& Triantis, 2005), while the final project performance depends on the effective alignment of idiosyncratic public and private resources and activities towards the mission of the project (Kivleniece \& Quelin, 2012). From a traditional governance perspective, it is argued that appropriate alignment of the formal rules to exchange condition is a sufficient behavioural driver for guaranteeing partners' contribution towards project performance (Chang, 2013).

However, practice and recent governance research indicate that relational governance elements are also crucial to the success of PPP projects (Tang, Shen, \& Cheng, 2010). Literature differentiates between two elements of relational governance: relational norms and trust (Cao \& Lumineau, 2015; Lu et al., 2015). Both are considered as relevant since they operate at different governance levels. While relational norms relate to values and social rules informally shared by project coalition members and, thus, operate external to a single individual (Macneil, 1980), trust is a psychological state of individual members of the project coalition (Kadefors, 2004). If these elements are brought together from a neoinstitutional organizational perspective, a governance model can be proposed, that sees the role of contracts particularly in their influence on relational norms that subsequently trigger trust and directly steer partners' contribution towards project performance (Figure 1.1).

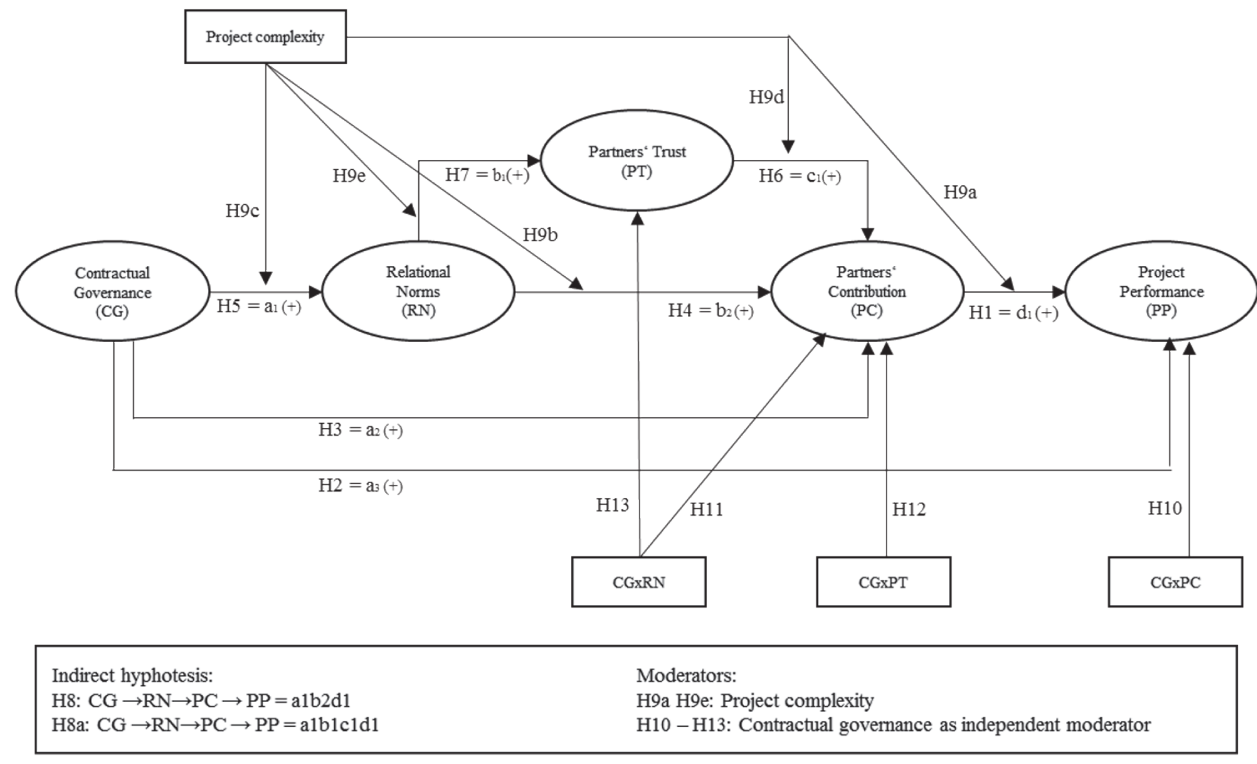

Figure 1.1 Structural model of contractual and relational governance in PPP projects 
From this perspective, contracts impact project performance by establishing a blueprint of behaviour, which defines the substantial content of the day-to-day relational rules for collaborating in projects (Zenger et al., 2000). In a PPP context, contractual provisions on risk transfer and payment linked to infrastructure availability constitute reference points for developing informal rules (relational norms) that allow managers to interact with each other and deal with project issues on a daily basis (Hart \& Moore, 2008). Relational norms emphasize values such as communication, inclusion and open discussion using as a reference the PPP contract provisions, given the imperative of aligning accountability and transparency requirements from public administration with the profit-oriented rationality of private organizations (Ling, Ong, Ke, Wang, \& Zou, 2014). The operation of shared relational norms on managers' cooperative behaviour (partners' contribution) is then mediated by their positive psychological expectations about the capacity and intention of their counterpart to comply with contractual roles and responsibilities. The operation of relational norms allows partners to mobilize resources and coordinate activities but also to build and reinforce trust. Then, trust further favours partners' contribution towards the mission of the project, which leads to project performance (Figure 1.1).

A number of additional relations were controlled in order to assess the robustness of the proposed model. First, the direct relationship between contractual governance and partners' contribution and the direct relationship between contractual governance and project performance are included in the model. Second, project complexity is added as a moderator since it may influence the relationship strength between governance elements. Third, contractual governance can independently moderate the effect between relational norms and trust, as well the relationship between these relational elements and partners' contribution, and the relationship between partners' contribution and project performance. In the following, these relationships between the model constructs are further theoretically underpinned and the associated hypotheses are presented.

\subsubsection{Project Performance and Partners' Contribution}

PPP agreements are the result of a process of negotiation and commitment between different social actors who may have competing values and eventually reach a shared vision based on the common idea that the materialization of a PPP project benefits their stakes (Hoezen, 2012). Thus, project performance is often conceptualized from the perspective of subjective satisfaction, given that different value claims and interests in projects lead to different perceptions of project success (Atkinson, 1999; Aubry, Richer, Lavoie-Tremblay, \& Cyr, 2011; Davis, 2014). In the field of Public-Private Partnerships, the multiplicity of stakes increases the ambiguity when measuring an overall "good outcome"(Verweij \& Gerrits, 2015). Furthermore, in the public sector"strategic objectives are not expressed in terms of profit and value to shareholders as in the private sector, but rather in terms of user satisfaction and value for a wide range of stakeholders, including politicians" (Aubry et al., 2011, p. 60) Defining a good outcome in PPPs is by no means straightforward, since many actors with different interests are involved (McGuire \& Agranoff, 2011). "Positive substantive outcomes are characterized by actors being satisfied based on their realized preferences and goals, and the time and energy spent achieving those preference and goals"(Verweij, Klijn, Edelenbos, \& Van Buuren, 2013, p. 1038). 
Regardless the specific claims of value capture and subjective definition of satisfaction, members of the PPP project coalition have a mutual responsibility to contribute to the process of value co-creation (Bygballe, Håkansson, et al., 2013). Final project outcomes require the coordination of individual contributions, in a continuous effort to array material processes by exploiting inter-organizational interdependences towards the completion of the project (Forsström, 2005; Thompson, 1967). It is important to clarify that partners' contribution cannot be defined a priori as part of relational governance, given that "cooperation does not necessarily require trust; it might be induced by coercion" (Kadefors, 2004, p. 176). Partners' contribution includes teamworking tasks and other activities for solving problems, disagreements and conflicts between parties involved in the project. Suprapto, Bakker, and Mooi (2015) provide quantitative evidence that the quality of teamworking processes positively impact project performance in the process industry. Likewise, Liu and Cross (2016) provide evidence of a positive relationship of cooperation and commitment between project teams and their outcomes. A positive correlation between cooperation and performance have been empirically supported for constructions projects (Ke et al., 2015), and innovation projects (Wu, Wang, \& Chen, 2017). Based on that, it is hypothesized that:

H1: Partners' contribution is positively associated with project performance

\subsubsection{Contractual Governance}

Contractual governance is regarded as a formal mechanism or constitutive rules defined in written documents and sanctioned through a formal position of authority and ownership (Zenger et al., 2000). Contractual governance is based on control in the extent to which collaboration and resulting project performance is the result of limiting the number of possible future project outcomes by allocating risks and setting enforceable standards aligned to the mission of the project (Brahm \& Tarziján, 2015; Guo, Chang-Richards, Wilkinson, \& Li, 2014; Teisman et al., 2009; S. Zhang, Zhang, Gao, \& Ding, 2016). Given that PPPs are single organizational arrangements between sovereign organizations (Borys \& Jemison, 1989; Kivleniece \& Quelin, 2012; Ménard, 1996), negotiated risk transfer and risk sharing regimes define legal responsibilities in the process of value co-creation (Bing, Akintoye, Edwards, \& Hardcastle, 2005; Chang, 2013; De Castro e Silva Neto et al., 2016; Grimsey \& Lewis, 2002). In this regard, the existence of a third party legally entitled to resolve disputes according to contractual obligations is a guarantee for the delivery of contractual compromises (Chang, 2013; Tarun K Das \& Teng, 1998; Macneil, 1980). In their research, Ke et al. (2015) found such a positive impact of contractual governance in the supply chain performance of construction projects. It is thus hypothesized that:

\section{H2: Contractual governance is positively associated with project performance}

Besides appealing to the control dimension, partners can use contracts as a point of reference for defining roles, coordinating activities and adapting the project to unforeseen circumstances without referring to corrective properties enforced by legal institutions (Hart \& Moore, 2008; Schepker, Oh, Martynov, \& Poppo, 2014; Wang, Chen, Fu, \& Zhang, 2017). In other words, PPP partners array coordinated contributions to the project based on clear specifications of what is allowed and what is not (Lu et al., 2015). Luo (2002) shows that cooperation is subject to the influence of contractual design, while Xue, Yuan, and Shi (2016) reach the same conclusion for joint-venture megaprojects 
with low levels of interpersonal relationships. Similarly, contract characteristics such as term specificity, adaptability and obligatoriness are found to negatively correlate with opportunism according to managers of construction projects (Lu, Zhang, \& Zhang, 2016). Based on that, it is hypothesized that:

H3: Contractual governance is positively associated with partners' contribution

\subsubsection{Relational Governance Elements}

\subsubsection{Relational Norms}

Relational norms are informal rules of social exchange such as flexibility, solidarity, participation in decision-making, communication and problem-solving through consultation. (Kaufmann \& Dant, 1992; Macneil, 1980; Xue et al., 2016). In the PPP context, relational norms emphasize the need to openly discuss and involve different perspectives for addressing project issues, given the diverse nature of public and private organizational logics (Rufín \& Rivera-Santos, 2012; Villani, Greco, \& Phillips, 2015), and the tacit concern of public transparency (Ke, Ling, \& Ning, 2013; Ling et al., 2014; Ning \& Ling, 2013). Accountability is crucial in the development of relational norms in PPPs (Klijn \& Koppenjan, 2016; Klijn, Steijn, \& Edelenbos, 2010), in order to avoid allegations of corruption from close relationships between public and private managers (Ke et al., 2013; Ling et al., 2014). Commitment and collaboration based on tacit understandings on how to organize teamwork on a daily basis lead to project predictability (Lu et al., 2015; Suprapto et al., 2015). Evidence from Dutch process industry projects indicates a positive relationship between relational norms, relational attitudes and team working quality (Suprapto et al., 2015), while joint planning and solving problems are positively correlated with relational norms (Zhou, Zhang, Zhuang, \& Zhou, 2015). Based on that, it is hypothesized that:

H4: Relational norms are positively associated with partners' contribution

Informal rules can be influenced by the intentional manipulation of formal institutions, being the latter a vehicle to steer behaviour (Lincoln, 1982; Stevenson, 1990). Contracts define a number of formal rules, operating as a point of reference for encouraging the development of informal relational norms (Cao \& Lumineau, 2015; Hart \& Moore, 2008). Chen and Manley (2014) provide evidence that the intensity of formal mechanisms is positively associated with the implementation of informal mechanisms in infrastructure projects. Based on that, it is hypothesized that:

H5: Contractual governance is positively associated with relational norms

\subsubsection{Partners'Trust}

Trust refers to a "psychological state comprising the intention to accept vulnerability based upon positive expectations of the intentions or behaviour of another" (Rousseau, Sitkin, Burt, \& Camerer, 1998, p. 395). As value creation at project level depends on the capability to mobilize, coordinate and adjust various actors towards a well-defined objective in a clear boundary setting (Bygballe, Håkansson, et al., 2013), trust facilitates the process of collaboration by means of increasing mutual reliability on individual contributions to the conclusion of the project (Kadefors, 2004; Wu et al., 2017). Then, project performance is the result of sustained collaboration triggered by the unspecified obligation of reciprocity based on trust (Blau, 1964). Trust permits partners to discard negative consequences in the 
future upon the confidence of a positive outcome and based on the expectation that others refrain from opportunistic behaviour (Meng, 2012; Tang et al., 2010; Teisman et al., 2009). Wu et al. (2017) provide evidence that relational trust positively impacts cooperative behaviours in high-tech projects, while it is negatively correlated with opportunistic behaviours. In a similar way, Ke et al. (2015) found a significant positive relationship between trust and cooperation in construction projects. Based on that, it is hypothesized that:

H6: Partners' trust is positively associated with partners' contribution

Relational norms furnish partners' trust taking into consideration that projects are temporal and highly coupled systems embedded in long-term and loosely coupled systems (Dubois \& Gadde, 2002). This embeddedness implies a complex grid of relational, sequential and pooled interdependencies as preexisting trust factors of project coalitions (Bygballe, Håkansson, et al., 2013). Formal contracts define the relational boundaries of a temporal project coalition imposing specific obligations, interaction rules and close interdependencies over long-lasting relationships in the network. Relational norms at project level reinforce pre-existing levels of trust between members of a project coalition. For global project teams, Henderson, Stackman, and Lindekilde (2016) provide evidence that perceptions of the alignment of informal rules in communication impact the levels of inter-personal trust. Based on that, it is hypothesized that:

H7: Relational norms are positively associated with partners' trust

\subsubsection{Relational Governance Elements as Mediators of Contractual Governance}

The mediating role of relational governance elements is based on the limited ability of formal rules to support exchange in comparison to informal rules and trust influencing behaviour (Granovetter, 1985; Scott, 1983). Contracts indirectly foster cooperation by promoting relational practices for mitigating misunderstandings. (Hoecht, 2004; Malhotra \& Murnighan, 2002; Ring \& Van de Ven, 1994). Based on research on collaborative infrastructure projects, Chen and Manley (2014) provide evidence that formal governance mechanisms are positively correlated with informal governance mechanisms, the latter mediating the impact of the former on project performance. Likewise, (Goo et al., 2009) provide evidence that contractual governance forms positively influence informal relational norms, being the latter a mediator between the former and partners' commitment in the context of software projects. Based on that, and taking into account the relationships defined in $\mathrm{H} 1, \mathrm{H} 4$ and $\mathrm{H} 5$ it is hypothesized that:

H8: The relationship between contractual governance and project performance is mediated by relational norms and partners' contribution

Research based on institutional theory has provided evidence that trust also plays a mediating role between organizational norms and collaborative practices (Wang, Tseng, \& Yen, 2014). In the context of contractual relations, focusing on formal roles and responsibilities favours a climate of fairness and informal practices that reinforce trust, leading to collaboration (Tarun K Das \& Teng, 1998; Dyer \& Chu, 
2003; Eshuis \& Van Woerkum, 2003; Yang, Su, \& Fam, 2012). Therefore, and taking into account H1, H5, $\mathrm{H} 6$ and $\mathrm{H7}$ :

H8a: The relationship between contractual governance and project performance is mediated by relational norms, partners' trust and partners' contribution

Project complexity can moderate the relationship between contractual and relational governance elements. As Kivleniece and Quelin (2012) have shown, a closer relational interaction between public and private parties is more important when higher levels of complexity are perceived, including technological complexity, external uncertainty and high exposure to social activism from stakeholders. When technological complexity, uncertainty and exposure to social activism are low, the value cocreation process can rely on a contractual-oriented mode of governance (Kivleniece \& Quelin, 2012). It is thus hypothesized that:

H9a: Project complexity positively moderates the relationship between partners' contribution and project performance

H9b: Project complexity positively moderates the relationship between relational norms and partners' contribution

H9c: Project complexity positively moderates the relationship between contractual governance and relational norms.

H9d: Project complexity positively moderates the relationship between partners' trust and partners' contribution

H9e: Project complexity positively moderates the relationship between relational norms and partners' trust

Finally, previous research based on the dichotomy perspective of the contractual/relational interplay has found that contractual governance can operate as an independent moderator. In particular, it can moderate the effect of relational governance elements on partners behaviours and project performance (Poppo \& Zenger, 2002). Even when contractual governance positively influences relational governance elements such as relational norms, paradoxically, higher levels of contractual governance can dampen at the same time "the level of trust and commitment through moderation effects" (Goo et al., 2009, p. 119). As there is also evidence indicating that this moderating effect can be present (Cao \& Lumineau, 2015), the following hypotheses are additionally considered:

H10: Contractual governance moderates the relationship between partners' contribution and project performance

H11: Contractual governance moderates the relationship between relational norms and partners contribution

H12: Contractual governance moderates the relationship between partners' trust and partners' contribution

H13: Contractual governance moderates the relationship between relational norms and partners'trust 


\subsection{RESEARCH DESIGN}

This study uses a confirmatory theory testing approach, which implies either accepting or rejecting a hypothesized structural model based on the statistical assessment of empirical evidence (Henseler et al., 2016). The structural model comprises direct and indirect relations between five constructs and moderating effects of project complexity and contractual governance (Figure 1.1). The unit of analysis is the governance structure and governing activity in PPP projects, and the unit of observation are managers working in these projects. Managers are considered as "key informants" (Goo et al., 2009; Segars \& Grover, 1998), since they have first-hand information on project organization properties, and their day-to-day activities are shaped by the formal and informal rules of the project (Zenger et al., 2000).

\subsubsection{Survey and Data Collection}

Data was collected through a survey of private and public managers involved in officially known PPP projects in the Netherlands, aiming at the whole population of ongoing projects. The covered PPPs included infrastructure, regional development projects and real estate projects. They were selected from official government documents and PPP advisory organizations. Respondents were identified based on the documents, the project websites and other information sources of the projects. To increase the possibility that a project is covered, for each project more than one person was selected with a maximum of three individuals involved in one project. Of the 343 public and private managers of 93 PPP projects that received the questionnaire ten respondents could not be reached (mail undeliverable) and 24 persons indicated that they would not like to fill in the survey or were not involved in the project. From the remaining 309 persons, 157 participated in the survey. 14 questionnaires were not completed and thus deleted from the initial data set. The 144 respondents (response percentage of 46,3\%) included in the analysis represent 68 PPP projects, covering $73 \%$ of PPP projects identified in the Netherlands. Respondents were employed in private consortia (27.1\%), consultancies (13.2\%), public organizations (45.8\%) and other organizations (11.8\%) such as non-profit organizations and law firms.

Regarding the level of variance explained by projects, a one-way M-ANOVA analysis was carried out for the data points for which respondents explicitly named the project $(n=128)$. Based on the analysis, there was a statistically significant difference between projects $(F(848,573)=1.341, p=.000$; Wilk's $\Lambda=$ 0.000 , partial $\eta 2=.649$ ). This indicates that about two thirds of the variance can be attributed to interproject variance, whereas one third can be attributed to intra-project variance. Common method bias was tested using PLS marker approach (Rönkkö \& Ylitalo, 2011), indicating that significant paths in the baseline model were also significant in the marker variable model. This evidence dissipates concerns about the common method bias.

\subsubsection{Method}

Consistent Partial Least Squares - Structural Equation Modeling (PLSc-SEM) was selected as a variancebased method to test hypothesized relations. PLS-SEM in general allows to assess non-direct causal relationships between variables, incorporating auxiliary measurement theories or non-observable/ 
latent variables measured indirectly by empirical indicators, and overcoming the need to impose restrictions on data, such as distribution assumptions required by other SEM techniques based on probability theory (Hair Jr, Hult, Ringle, \& Sarstedt, 2013). PLSc-SEM in particular remedies the adverse consequences of using ordinary PLS when estimating common factor models for hypothesis testing, which have supported the claim that variance-based SEM methods are less suitable for hypothesis testing comparing to covariance-based SEM methods (Dijkstra \& Henseler, 2015). Updated guidelines for using PLSc path modelling developed by Henseler et al. (2016) were used to assess the model. According to the guidelines, results should be first assessed globally (overall model), and then locally (measurement models and structural model). The PLSc-SEM algorithm was run using 4.999 bootstrap samples to determine the likelihood of obtaining a discrepancy between the empirical and the modelimplied correlation, and estimating direct and indirect effects for conducting mediation analysis.

\subsubsection{Measurement Model}

Contractual governance (Exogenous - Composite): The measure includes five items, scored on a 1-10 scale between two dichotomic statements derived from literature. The variable is modelled as composite as it emerges from the particular configuration of different contractual attributes: control, coordination and adaptation (Schepker et al., 2014). Two items address the control dimension sanctioned upon legal obligations: CG1-Complexity: (From 1- 'The contract is difficult to understand" to 10- "The contract is easy to understand"), CG2-Sanction: (From 1- "The contract has no possibilities for imposing sanctions if the contract terms are not met" to 10- "The contract has many possibilities for imposing sanctions if the contract terms are not met"). Two items address the coordinating dimension of the contract to adapt project to unforeseen circumstances: - CG3-Flexibility: (From 1- "The contract is characterized by fixed target values and norms regardless of the circumstances" to 10- "The contract is characterized by flexible target values and norms that can be reduced or enhanced under certain circumstances"), and - CG4-Negotiation: (From 1- "The contract offers very little space for negotiation" to 10- "The contract offers much space for negotiation"). Finally, subscribing that the core of a PPP contract is transferring or negotiating project risks (Chang, 2013), the final indicator is - CG5-Risk sharing: (From 1- "Financial risk is not shared between partners to a great extent" to 10- "Financial risk is shared between partners").

Project relational norms (Endogenous - Composite): The measure includes seven indicators derived from the literature (scoring a statement from a 1-5 scale, where one is "totally disagree" and five is "totally agree"). The first indicator refers to general norms as non-binding rules for organizing public and private relations following the general tenets of Kaufmann and Dant (1992) and Macneil (1980) RN1 - "There are organizational arrangements to facilitate interaction between parties". The other six indicators are retrieved from Klijn et al. (2010), who specify indicators on informal norms to govern relations in publicprivate networks. Two indicators measure the involvement of key actors for addressing project issues: RN2-Contractor involvement: "(Private) contractors are consulted and involved in project management decisions", and - RN3-Stakeholder involvement:"Attention has been paid to the involvement of external stakeholders (citizens, environmental groups, other public actors) and their opinions". Two indicators address transparency, - RN4-Perspective diversity: "In the decision-making process about the project different views are included and made visible", and - RN5-Communication effort: "Time is spent in communicating between parties (contract parties as well external parties)". Finally, two indicators 
measure the norms for solving problems by means of consultation - RN6-Common basis: "During information collection, emphasis was placed on establishing common starting points and common information needs between public and private parties in this project", and - RN7-Problem solving: "When deadlock was reached, or problems arose in the project, the project management tried to find common ground between the conflicting interests".

Partners' Trust (Endogenous - Single Item): The measure considers trust as a psychological state of mutual reciprocity based upon positive expectations of others intentions (Kadefors, 2004). A single measure is used (10-point Likert scale between two dichotomic statements) to capture this psychological state - PT1-Trust: (From 1- "There is no trust between the public and private parties" to 10 "There is much trust between the public and private parties"). The high level of abstraction of a single-item allows measuring the attitudinal nature of trust, irrespectively of their source or dimension. This approach is suggested by Medlin and Quester (2002), who argue that due to the difficulties in the operationalization and measurement of inter-organizational trust and its suggested dimensions, it could and should be treated as a one-dimensional, global measure. The selection of a one-single item to measure trust is common in the design of National surveys on trust and Social capital, such as the one conducted by the National Opinion Research Center's General Social Survey (Glaeser, Laibson, Scheinkman, \& Soutter, 2000).

Partners' contribution (Endogenous - Factor): "Partners Contribution" measures the actual behaviour of cooperation between partners during the process of completing and delivering the project (Procaccino, Verner, Shelfer, \& Gefen, 2005), irrespective of its source (coercion, economic incentives or trust) (Kadefors, 2004). This construct is measured with four items, on a scale from 1 to 5 where one is "totally disagree" and five is "totally agree". These items are used to measure process outcomes in the context of projects involving networks of public and private organizations and other types of stakeholders (Klijn et al., 2010): - PC1: "Activities of the involved parties are coordinated (aligned)", PC2: "The involved contract partners have contributed to the completion of the project in an accurate way", - PC3: "The involved organizations in the network have adequate ways to command mutual disagreements and conflicts successfully", and - PC4: "During the past years, parties have improved their collaboration". As a factor, it reflects the measured variance of its corresponding indicators assuming that they reflect an underlying common concept based on true score theory (Henseler et al., 2016, p. 33).

Project performance (Endogenous - Composite): The measure includes six items (scored on a $1-5$ scale, where one is "totally agree" and five is "totally disagree") taking into account the diversity of projects examined (infrastructure, regional development projects and real estate projects), and assuming that performance emerges from the configuration of different definitions of value (Ahola et al., 2014). The first item measures the general satisfaction taking into account different value claims and interests (Aubry et al., 2011): - PP1:"The project solutions are sufficiently supported by the organizations involved". The rest of items measures the satisfaction in terms of functionality, quality and efficiency (Winch, 2010). Two items measure functionality: - PP2: "Different spatial functions have been connected sufficiently in the project", and - PP3: "Solutions developed in the project truly deal with the problems at hand". One item measures quality overtime: - PP4: "Developed solutions in the project are durable for the future". Two items measure economic efficiency: - PP5: "The costs of the 
project stay within the limits that have been set", and - PP6: "In general, the benefits of the project exceed the costs".

Perceived Project Complexity (Moderator - Composite): The measure includes three items, scored on a 1-10 scale between two dichotomic statements:- CPLX1: Technological complexity (From 1 "The project was characterized by low technological complexity" to 10- "The project was characterized by high technological complexity"), CPLX2: External conditions (From 1 - "The project is hardly affected by external conditions - for instance like safety regulations, nature requirements, etc." to 10- "The project is strongly affected by external conditions - for instance like safety regulations, nature requirements, etc."). CPLX3 External stakeholders (From 1-"The project was characterized by a low number of external stakeholders" to 10- "The project was characterized by a high number of external stakeholders").

\section{$1.4 \quad$ RESULTS}

\subsubsection{Overall Fit of the Model}

Three general tests were conducted to identify both, measurement model misspecification and structural model misspecification: maximum likelihood discrepancy (SRMR), the geodesic discrepancy $d_{G^{\prime}}$ and unweighted least squares discrepancy $d_{\text {ULS }}$ (Table 1.1). As resulting values should be lower than the selected bootstrap quantile, the model met the criteria for HI95 quantile. Furthermore, the model score for SRMR is 0.054 which suggests a good overall fit, taking into account that a value of 0 for SRMR would indicate a perfect fit and a value lower than 0.08 indicates an acceptable fit.

Table 1.1 Overall goodness of model fit (estimated model results)

\begin{tabular}{lll} 
Criterion & Value & HI95 \\
SRMR & 0.054 & 0.067 \\
\hline$d_{\text {ULS }}$ & 0.398 & 0.608 \\
\hline$d_{G}$ & 0.172 & 0.249 \\
\hline
\end{tabular}

\subsubsection{Measurement Model}

For factor constructs, the most relevant internal consistency reliability measure in PSLC modelling is Dijkstra-Henseler's rho (PA), which should be higher than 0.7 (Dijkstra \& Henseler, 2015). The factor construct partners' contribution scored 0.75 PA, implying an acceptable amount of random error. For convergent validity, the usual measure is the Average Variance Extracted (AVE) that should be higher than 0.5 to be considered acceptable. Given that the AVE factor scored 0.48 , there is the possibility that the factor construct was not able to extract a dominant factor. Therefore, a second test was carried for assessing unidimensionality following the method of Sahmer, Hanafi, and Qannari (2006) based on Kaiser (1992) rule. It consists of evaluating a factor construct as unidimensional if the eigenvalue of the higher outload is larger than 1 and the second eigenvalue of the smallest outload is smaller than 1. 
With a bootstrap size of 100,000, the eigenvalue of the highest outload was 1.94, while the eigenvalue of the lowest outload was 0.642 providing evidence of convergent validity. It was not necessary testing discriminant validity, taking into account that the model only includes one factor construct. Indicators were excluded when their outer loads were smaller than 0.4 (Churchill Jr, 1979) and construct reliability or validity could be increased (Table 1.2).

Table 1.2 Factor assessment and results

Factor construct (PA) AVE Item

\begin{tabular}{lll} 
PC1 & Activities of the involved parties are coordinated (aligned) ${ }^{b}$ & NA \\
\hline PC2 & $\begin{array}{l}\text { The involved contract partners have contributed to the } \\
\text { completion of the project in an accurate way }\end{array}$ & 0.829 \\
\hline
\end{tabular}

Partners'

Contribution
The involved organizations in the network have adequate

PC3 ways to command mutual disagreements and conflicts 0.608 successfully

PC4 During the past years, parties have improved their collaboration

a Second test: eigenvalue highest outload $1.94>0$; and lowest outload $0.64<0$

b Item eliminated in order to increase Convergent Validity

For assessing reliability and validity of composite constructs the major point of departure is the confirmatory composite analysis (Henseler et al., 2014), which assessment was carried out when evaluating the overall model-fit (SRMR $<95 \%$ bootstrap HI95 quantile, see Table 1.1) ${ }^{10}$. For collinearity, the assessment of the Variance Inflation Factor (VIF) revealed values below 2.0 for all indicators discarding collinearity issues. Indicators were excluded when their outer weight was not significant (T-value below $1.65(a=.10)$ ), except when keeping the indicator would increase the confirmatory composite analysis score (SRMR score) as PLSc defines consistency at large.

\footnotetext{
${ }_{9}^{9}$ Given that PLSC defines consistency at large "one should be careful when eliminating indicators. Only if an indicator's reliability is low and eliminating this indicator goes along with a substantial increase of construct reliability, it makes sense to discard this indicator" (Henseler, Ringle, \& Sinkovics, 2009, p. 299)

${ }^{10}$ Confirmatory composite analysis can be regarded as a pragmatic criteria for detecting measurement model specification, as it "determines the exact fit of the composite factor model by means of bootstrapping the conventional likelihood function" (Henseler et al., 2014, p. 194)
} 
Table 1.3 Composites assessment and results

\begin{tabular}{|c|c|c|c|c|}
\hline \multirow{2}{*}{$\begin{array}{l}\text { Composite } \\
\text { construct }\end{array}$} & \multicolumn{2}{|c|}{ Indicator } & \multirow{2}{*}{$\begin{array}{l}\text { Weight } \\
0.275\end{array}$} & \multirow{2}{*}{ T-values } \\
\hline & CG1 & The contract is simple to understand ${ }^{a}$ & & \\
\hline \multirow{4}{*}{$\begin{array}{l}\text { Contractual } \\
\text { Governance }\end{array}$} & CG2 & $\begin{array}{l}\text { The contract has many possibilities for imposing sanctions if the } \\
\text { contract terms are not met }\end{array}$ & 0.640 & 3.13 \\
\hline & CG3 & $\begin{array}{l}\text { The contract is characterized by fixed target values and norms } \\
\text { regardless of the circumstances }{ }^{b}\end{array}$ & NA & NA \\
\hline & CG4 & The contract offers much space for negotiation & 0.329 & 1.66 \\
\hline & CG5 & Financial risk is shared between public and private partners & 0.507 & 2.29 \\
\hline \multirow{7}{*}{$\begin{array}{l}\text { Project Relational } \\
\text { Norms }\end{array}$} & RN1 & $\begin{array}{l}\text { There are organizational arrangements to facilitate interaction } \\
\text { between parties }\end{array}$ & 0.242 & 1.81 \\
\hline & RN2 & $\begin{array}{l}\text { (Private) implementers are consulted and involved in decisions } \\
\text { of the project management }\end{array}$ & 0.265 & 1.81 \\
\hline & RN3 & $\begin{array}{l}\text { Attention has been paid to the involvement of external } \\
\text { stakeholders (citizens, environmental groups, other public actors) } \\
\text { and their opinions }{ }^{b}\end{array}$ & NA & NA \\
\hline & RN4 & $\begin{array}{l}\text { In the decision-making process about the different project, views } \\
\text { are made visible and included }\end{array}$ & 0.417 & 3.79 \\
\hline & RN5 & $\begin{array}{l}\text { Time is spent in communicating between parties (contract parties } \\
\text { and external parties) }\end{array}$ & NA & NA \\
\hline & RN6 & $\begin{array}{l}\text { During information collection, an emphasis was placed on } \\
\text { establishing common starting points, and common information } \\
\text { needs }^{b}\end{array}$ & NA & NA \\
\hline & RN7 & $\begin{array}{l}\text { When a deadlock was reached, or problems arose in the project, } \\
\text { management tried to find common ground between the } \\
\text { conflicting interests }\end{array}$ & 0.479 & 3.19 \\
\hline \multirow{6}{*}{$\begin{array}{l}\text { Project } \\
\text { Performance }\end{array}$} & PP1 & $\begin{array}{l}\text { The project solutions are sufficiently supported by the } \\
\text { organizations involved }^{\text {a }}\end{array}$ & 0.132 & 1.00 \\
\hline & PP2 & $\begin{array}{l}\text { Different environmental functions have been connected } \\
\text { sufficiently }{ }^{b}\end{array}$ & NA & NA \\
\hline & PP3 & $\begin{array}{l}\text { Solutions developed in the project really deal with the problems } \\
\text { at hand }\end{array}$ & 0.303 & 1.93 \\
\hline & PP4 & Developed solutions in the project are durable for the future & 0.395 & 2.99 \\
\hline & PP5 & The cost of the project stays within the limits that have been set & 0.426 & 2.92 \\
\hline & PP6 & In general, the benefits exceed the costs ${ }^{b}$ & NA & NA \\
\hline
\end{tabular}

a Indicator retained regardless non-significant weight, as it increases SRMR score

${ }^{\mathrm{b}}$ Indicator eliminated duet to non-significant weight

\subsubsection{Structural Model and Hypothesis Testing}

The central criterion for assessing the structural model is accounting for the coefficient of determination $\mathrm{R}^{2}$, which measures the explanatory power of the model in terms of the variation in the endogenous constructs (Figure 1.2). According to adjusted $\mathrm{R}^{2}$ assessment of the endogenous 
variables, the percentage of variation explained for relational norms and partners' trust is rather weak, and stronger for partners' contribution and project performance ${ }^{11}$. In order to provide a detailed picture of the theory tested, the analysis is organized in three steps: (a.) assessing direct relationships; (b.) classifying mediations (and no-mediations) according to the typology established by Zhao, Lynch Jr, and Chen (2010); and, (c.) assessing compound paths by means of direct, indirect and total effects. Results provide support to $\mathrm{H} 1, \mathrm{H} 4, \mathrm{H} 5, \mathrm{H} 6$, and $\mathrm{H} 7$, but they do not support $\mathrm{H} 2$ and $\mathrm{H} 3$ (Figure 1.2). The evidence of these direct effects provides support for the hypothesis $\mathrm{H} 8$ and $\mathrm{H} 8 \mathrm{a}$.

Figure 1.2 Results for the structural model and direct hypothesis

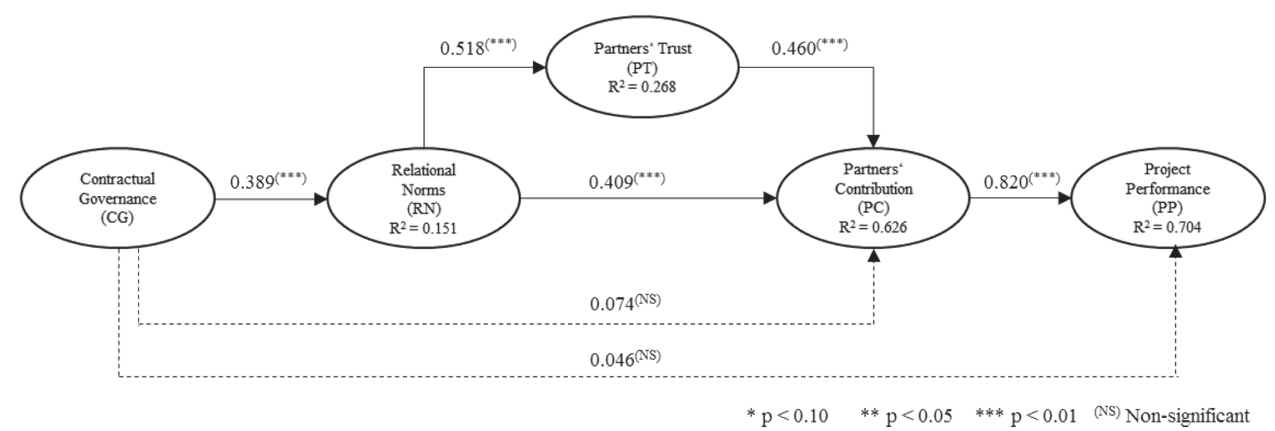

\begin{tabular}{llcccc} 
Direct Hypothesis & Path & & Path value & Significance (p-value) & Hypothesis Supported \\
$\mathrm{H} 1$ & $\mathrm{PC} \rightarrow \mathrm{PP}$ & $\mathrm{d}_{1}$ & 0.820 & 0.000 & YES \\
\hline $\mathrm{H} 2$ & $\mathrm{CG} \rightarrow \mathrm{PP}$ & $\mathrm{a}_{3}$ & 0.046 & 0.670 & $\mathrm{NO}$ \\
\hline $\mathrm{H} 3$ & $\mathrm{CG} \rightarrow \mathrm{PC}$ & $\mathrm{a}_{2}$ & 0.074 & 0.559 & $\mathrm{NO}$ \\
\hline $\mathrm{H} 4$ & $\mathrm{RN} \rightarrow \mathrm{PC}$ & $\mathrm{b}_{2}$ & 0.409 & 0.000 & YES \\
\hline $\mathrm{H} 5$ & $\mathrm{CG} \rightarrow \mathrm{RN}$ & $\mathrm{a}_{1}$ & 0.398 & 0.000 & YES \\
\hline $\mathrm{H} 6$ & $\mathrm{PT} \rightarrow \mathrm{PC}$ & $\mathrm{c}_{1}$ & 0.460 & 0.000 & YES \\
\hline $\mathrm{H} 7$ & $\mathrm{RN} \rightarrow \mathrm{PT}$ & $\mathrm{b}_{1}$ & 0.518 & 0.000 & YES \\
\hline
\end{tabular}

The strongest direct relationships are estimated for $\mathrm{H} 1$ and $\mathrm{H}^{12}$, according to which partners' contribution has a positive effect on project performance $\left(d_{1}=0.820, p<0.01, f^{2}=2,05\right)$; and, relational norms have a positive effect on partners' trust $\left(b_{1}=0.518, p<0.01, f^{2}=0.37\right)$. Moderate relationships are estimated for H6 $\left(c_{1}=0.460, p<0.01, f^{2}=0.26\right), H 4\left(b_{2}=0.409, p<0.01, f^{2}=0.20\right)$ and H5 $\left(a_{1}=0.398\right.$, $\left.p<0.01, f^{2}=0.17\right)$.

\subsubsection{Mediation hypothesis $\mathrm{H} 8$ and $\mathrm{H} 8 \mathrm{a}$}

Mediation analysis follows Zhao et al. (2010) and Nitzl, Roldan, and Cepeda (2016), who revisit the traditional criteria for defining and testing mediation developed by Baron and Kenny (1986). From discarding $\mathrm{H} 2$ and $\mathrm{H} 3$, and following Zhao et al. (2010) it can be concluded that the effect of contractual governance on project performance is mediated by relational norms, partners' trust and

\footnotetext{
11 "In scholarly research that focuses on marketing issues, R2 values of $0.75,0.50$, or 0.25 for endogenous latent variables can, as a rough rule of thumb, be described as substantial, moderate, or weak" (Hair Jr et al., 2013, p. 175)

${ }^{12}$ Cohen $\mathrm{f}^{2}$ values above $0.35,0.15$ and 0.02 can be regarded as strong, moderate and weak, respectively (Henseler et al., 2016)
} 
partners contribution. In particular, there is an indirect-only mediation of relational norms between contractual governance and partners' contribution given the support for $\mathrm{H} 4$ and $\mathrm{H} 5$. Second, there is an indirect-only mediation of relational norms between contractual governance and partners' trust given the support for $\mathrm{H} 5$ and $\mathrm{H} 7$. The assessment of the total effect of contractual governance on project performance (Coeff. $=0.314, \mathrm{p}<0.01$ ) provides support for $\mathrm{H} 8$ and $\mathrm{H} 8 \mathrm{a}$. The expected net relationship from Contractual Governance to Project Performance for H8a - including partners'trust (Coeff. $=0.078$ ) is lower than the path calculated for $\mathrm{H} 8$-excluding partners' trust (Coeff. $=0.133)^{13}$. Additionally, the total effect of relational norms on project performance (Coeff. $=0.530, p<0.01$ ) is higher than the total effect of partners' trust on project performance (Coeff. $=0.377, \mathrm{p}<0.01$ )

Table 1.5 Direct, Indirect and Total effects between constructs

\begin{tabular}{|c|c|c|c|c|c|}
\hline \multicolumn{2}{|c|}{ Precursor variableEffect } & \multirow{2}{*}{$\begin{array}{c}\text { Relational } \\
\text { Norms } \\
0.389^{* * *}\end{array}$} & \multirow{2}{*}{$\begin{array}{c}\text { Partners' } \\
\text { Trust }\end{array}$} & \multirow{2}{*}{$\begin{array}{c}\text { Partners' } \\
\text { Contribution } \\
0.074^{(\mathrm{NS})}\end{array}$} & \multirow{2}{*}{$\begin{array}{c}\text { Project } \\
\text { Performance } \\
0.046^{\text {(NS) }}\end{array}$} \\
\hline \multirow{3}{*}{$\begin{array}{l}\text { Contractual } \\
\text { Governance }\end{array}$} & Direct & & & & \\
\hline & Indirect & & $0.202^{* * *}$ & $0.252^{* * *}$ & $0.267^{* *}$ \\
\hline & Total & $0.389^{* * *}$ & $0.202^{* * *}$ & $0.326^{* * *}$ & $0.314^{* * *}$ \\
\hline \multirow{3}{*}{ Relational Norms } & Direct & & $0.518^{* * *}$ & $0.409^{* * *}$ & \\
\hline & Indirect & & & $0.238^{* * *}$ & $0.530^{* * *}$ \\
\hline & Total & & $0.518^{* * *}$ & $0.647^{* * *}$ & $0.530^{* * *}$ \\
\hline \multirow{3}{*}{ Partner Trust } & Direct & & & $0.460^{* * *}$ & \\
\hline & Indirect & & & & $0.377^{* * *}$ \\
\hline & Total & & & $0.460^{* * *}$ & $0.377^{* * *}$ \\
\hline \multirow{3}{*}{$\begin{array}{l}\text { Partners' } \\
\text { Contribution }\end{array}$} & Direct & & & & $0.820^{* * *}$ \\
\hline & Indirect & & & & \\
\hline & Total & & & & $0.820^{* * *}$ \\
\hline
\end{tabular}

* $p<0.10^{* *} p<0.05^{* * *} p<0.01^{\text {(NS) Non-significant }}$

\subsubsection{Moderation Analysis}

\subsubsection{Project Complexity H9a and H9b}

Two-stage continuous moderation analysis developed by Fassott et al. (2016) was used for assessing project complexity (Table 1.6). Results provide partial support for H9a and H9c. Project complexity positively moderates the relationship between partners' contribution and project performance $(\mathrm{H} 1)$, as well as the relationship between contractual governance and relational norms (H5). For projects with an average level of complexity, the effect of partners' contribution on project performance scores 0.672 ( $p<0.01$ ), and the effect of contractual governance on relational norms scores $0.369(p<0.01)$. However, for those projects which complexity ranks one standard deviation above the average, the effect of partners' contribution on project performance increases up to 819, and the effect of contractual governance on relational norms increases up to 0.551 . This is due the moderating effect, which represents an additional $0.147(p<0.05)$ for the former, and an additional 0.182 for the latter $(p<0.05)$.

\footnotetext{
${ }^{13}$ The expected net relationship is calculated by multiplying the path value of the direct relationships included in the mediation chain. For $\mathrm{H} 8=\mathrm{a}_{1}{ }^{*} \mathrm{~b}_{2}{ }^{*} \mathrm{~d}_{1}=0.389^{*} 0.409^{*} 0.820=0.133$, and for $\mathrm{H} 8 \mathrm{a}=\mathrm{a}_{1}{ }^{*} \mathrm{~b}_{1}{ }^{*} \mathrm{c}_{1}{ }^{*} \mathrm{~d}_{1}=0.389^{*} 0.518^{*} 0.460 * 0.820=0.078$
} 
Table 1.6 PLS -Two-stage Moderation Analysis - Project Complexity

\begin{tabular}{lccc}
$\mathrm{H}$ & Direct relationship & Baseline model & Moderation model \\
$\mathrm{H} 1$ & $\mathrm{PC} \rightarrow \mathrm{PP}$ & $0.820^{* * *}$ & $0.672^{* * *}$ \\
\hline $\mathrm{H} 9 \mathrm{a}$ & & & $0.147^{* *}$ \\
\hline $\mathrm{H} 4$ & $\mathrm{RN} \rightarrow \mathrm{PC}$ & $0.409^{* * *}$ & $0.349^{* * *}$ \\
\hline $\mathrm{H} 9 \mathrm{~b}$ & & & $0.048(\mathrm{NS})$ \\
\hline $\mathrm{H} 5$ & $\mathrm{CG} \rightarrow \mathrm{RN}$ & $0.398^{* * *}$ & $0.369^{* * *}$ \\
\hline $\mathrm{H} 9 \mathrm{c}$ & & $0.182^{* *}$ \\
\hline $\mathrm{H} 6$ & $\mathrm{PT} \rightarrow \mathrm{PC}$ & $0.460^{* * *}$ & $0.392^{* * *}$ \\
\hline $\mathrm{H} 9 \mathrm{~d}$ & & & $0.051(\mathrm{NS})$ \\
\hline $\mathrm{H} 7$ & $\mathrm{RN} \rightarrow \mathrm{PT}$ & $0.518^{* * *}$ & $0.483^{* * *}$ \\
\hline $\mathrm{H} 9 \mathrm{e}$ & & & $0.123(\mathrm{NS})$ \\
\hline
\end{tabular}

${ }^{*} p<0.10^{* *} p<0.05^{* * *} p<0.01^{\text {(NS) Non-significant }}$

\subsubsection{Contractual Governance as Moderator H10 - H13}

Table 1.7 presents the results from modelling contractual governance as independent moderator of the relationships between relational norms and partners' trust $(\mathrm{H} 10)$, relational norms and partners' contribution ( $\mathrm{H} 11)$, partners' trust and partners' contribution ( $\mathrm{H} 12)$, and partners' contribution and project performance (H13). No moderation effect was significant.

Table 1.7 PLS -Two-stage Moderation Analysis - Contractual Governance

\begin{tabular}{lccc}
$\mathrm{H}$ & Direct relationship & Baseline model & Moderation model \\
$\mathrm{H} 1$ & $\mathrm{PC} \rightarrow \mathrm{PP}$ & $0.820^{* * *}$ & $0.679^{* * *}$ \\
\hline $\mathrm{H} 10$ & & & 0.002 (NS) \\
\hline $\mathrm{H} 4$ & $\mathrm{RN} \rightarrow \mathrm{PC}$ & $0.409^{* * *}$ & $0.354^{* * *}$ \\
\hline $\mathrm{H} 11$ & & $0.460^{* * *}$ & -0.000 (NS) \\
\hline $\mathrm{H} 6$ & $\mathrm{PT} \rightarrow \mathrm{PC}$ & & $0.389^{* * *}$ \\
\hline $\mathrm{H} 12$ & & $0.518^{* * *}$ & $-0.074(\mathrm{NS})$ \\
\hline $\mathrm{H} 7$ & $\mathrm{RN} \rightarrow \mathrm{PT}$ & & $0.522^{* * *}$ \\
\hline $\mathrm{H} 13$ & & & 0.043 (NS)
\end{tabular}

\subsection{DISCUSSION}

In line with theoretical insights from new institutional economics, this study brings into light the role of relational norms and trust as relational mediators between contractual governance and partners contribution, and subsequently PPP project performance. A fundamental proposition states that informal institutions define the actual behaviours of players, while formal institutions influence the trajectory of informal institutions (Zenger et al., 2000). This study provides empirical evidence 
for the argument in project management literature that relational aspects mediate the effect of formal organizational designs on project coalitions' capacity to coordinate tasks, reach high levels of cooperation and increase project performance (Bresnen \& Marshall, 2002; Chen \& Manley, 2014; Joslin \& Müller, 2016; Suprapto et al., 2015; Wu et al., 2017; Xue et al., 2016). Additionally, this study contributes to the current literature in PPPs, extensively focused on the direct relationship between contractual designs and project performance (De Castro e Silva Neto et al., 2016). The presented insights contribute to the call for examining how and when contractual and relational governance interact (Cao \& Lumineau, 2015; L. Poppo \& Zenger, 2002), moving away from the traditional dichotomy between substitution or complementarity.

Overall, this study provides evidence for conceptualizing the interplay from a procedural logic; as a sequence of relationships between contractual and relational governance elements. Relational governance elements (relational norms and trust) play their mediating role on the blueprint provided by contractual governance elements, and translate these contractual provisions into contributions of project partners. Literature from process analysis has introduced enabling and compensating properties for describing the procedural logic of the interplay between governance mechanisms (Huber, Fischer, Dibbern, \& Hirschheim, 2013). In the following, these categories will be used for discussing the significance of the mediating effects found.

\subsubsection{Interpreting Mediation: Enabling Mechanism}

The results of the study suggest that contractual governance enables relational governance, providing a blueprint for behaviour. Then, relational governance compensates the inherent limitations of contractual governance. In comparison to the dichotomy of substitution and complementarity, compensating and enabling properties can logically coexist along a cascade of enablers from formal rules, to informal rules, psychological disposition, cooperative behaviour and satisfactory project results. Contractual governance shapes relational norms oriented to encourage reliable mutual attitudes based on trust. The latter functions as a complementary mediator of relational norms being the driver for collaborative practices and activities contributing to project performance. The enabling logic is based on the argument according to which formal rules constitute a tool available to managers through which informal rules can be shaped (Zenger et al., 2000). And these rules have an impact on individuals, predisposing them to engage in collaborative practices regardless of the system of control in place. As the results of this study indicate, performance is the result of these cooperative practices, which are rather driven by trust and informal rules than formal enforceable rules.

In more detail, the study shows that an appropriate contractual design encourages the development of particular informal rules of relational exchange (Luo, 2002; Malhotra \& Lumineau, 2011; Schepker et al., 2014). Space for negotiation upon a shared risk regime (CG4, CG5) might furniture the possibility to develop relational norms for dealing with changing circumstances that cannot be defined in the original contract (Tushar Kanti Das \& Teng, 2001; Kivleniece \& Quelin, 2012). The control dimension imposes a formal warrant (CG2) for defining relational norms that, actually allow partners to fulfil contractual obligations (Deakin \& Wilkinson, 1998; Li, Poppo, \& Zhou, 2010; Woolthuis, Hillebrand, \& Nooteboom, 2005). The contract can trigger partners to focus on roles and responsibilities, being the initial point of reference for finding common ground between diverse perspectives for addressing 
problems (RN3 RN7) and solving misunderstandings (Malhotra \& Lumineau, 2011). Relational norms initially emerge from the implementation of discrete contractual choice (Lincoln, 1982; Stevenson, 1990; Zenger et al., 2000), and then turn into an implicit understanding sanctioned by the strength of the informal ties built between partners. Trust from collaborative practices allows partners to increase mutual certainty about the scope and commitment on fulfiling their roles and responsibilities in the process of value co-creation (Kadefors, 2004; Wu et al., 2017).

\subsubsection{Interpreting Mediation: Compensating Mechanism}

Nevertheless, the explained variance of relational norms and trust in the model is weak, implying the existence of other factors that account for these two variables (Kadefors, 2004). From this perspective, relational governance seems to operate as an independent factor that compensates contractual governance. Its role is encouraging contributions of the partners to the project, mediating the longterm contractual commitment and day-to-day collaborative interaction and activities which lead to project performance. This inference is empirically supported by the fact that the strongest effect measured in the model is the overall effect of relational norms on project performance (including the mediating effect of partners' trust and partners' contribution). The underlying logic of relational governance as a compensator of contractual governance must be understood in the light of the wellknown incomplete nature of contractual forms (Gilson, Sabel, \& Scott, 2010; Hart \& Moore, 2008; Luo, 2002).

Relational norms compensate long-term contractual governance design by defining day-to-day collaborative micro-practices, which nature and dynamics are not formalized as obligations to perform in advance (Bresnen \& Marshall, 2002; Gibbons, 2010; Zheng et al., 2008). Relational norms directly influence partners' attitudes and behaviour to engage in collaborative activities in the process of delivering project outcomes (Lu et al., 2015; Olander et al., 2010). This may include informal rules for including different perspectives (RN2, RN4), in conjunction with arrangements for facilitating interaction (RN1), and the rule of finding a common ground to address conflicts (RN7). In practice, these elements facilitate the management of the project when future unfolds, and new issues emerge not regulated by the contract.

\subsubsection{Interpreting Mediation: Moderating Effect of Project Complexity}

Finally, according to the moderation analysis project complexity is a positive moderator of the relationship between contractual governance and project relational norms, and partners' contribution and project performance. Depending on project complexity partners may experience a higher level of uncertainty about the extent to which initial contractual provisions hold in the future. Greater uncertainty requires stronger joint management, increasing the relevance of relational norms addressing substantive project issues. Then, both elements of relational governance (relational norms and trust) operate as a vehicle to compensate original contractual gaps given the necessarily incomplete nature of PPP contracts. On the other hand, the observed positive moderating effect of project complexity is also aligned with the theoretical proposition that higher levels of complexity require crafting tighter collaboration structures at the front-end of the project (Kivleniece \& Quelin, 2012). From this perspective, partners intentionally establish contractual structures ex-ante that enable 
collaborative procedures to review project expectations and adapt partners' obligations ex-posts according to changing conditions.

\subsubsection{Managerial Implications}

A managerial implication of this study is that partners in PPP projects should consider relational norms as a key aspect for organizing day-to-day partners' contributions and maintaining their commitment in a typical long-term contract. For example, establishing relational norms allows seizing potential collaborative relations defined in contracts, including risk share regimes and transparent re-negotiations. This is particularly relevant when facing complexity: scenarios where partners are required to invest collaborative efforts to manage technological complexity, stakeholders' activism and impact of external events. PPP contracts can encourage project performance, but this positive effect requires to explicitly define the role of relational norms and trust-building process in and uncertainty management.

\subsubsection{Limitations}

The data of this study only includes PPP projects in the Netherlands, restricting the possibility to generalize the conclusions to countries with different institutional configuration. In this regard, the typical corporatist tradition of Dutch institutional and cultural settings might accentuate the relevant of relational elements between public and private actors. Finally, causal inferences were based on assumed causal directions from literature with the expectation of strong feedbacks over time. In other words, it was assumed a one-direction relationship between contractual and relational governance, when their interplay is complex and certainly influences both ways. To overcome this limitation, it is required to implement longitudinal research designs based on the actuality of projects, as well as considering techniques, such as two-stage least squares (Henseler et al., 2016) or simulation methods such as System Dynamics (Sterman, 2000) to assess feedback loops over time and endogeneity. Additionally, this paper does not make statements about the objective performance of projects, and it explicitly frames "project performance" construct from the perspective of subjective satisfaction".

\subsection{CONCLUSION}

The inquiry on how to organize the interface between public and private parties in PPP projects has its grounds on the challenge to unravel the complex interplay between contractual and relational governance in the process of value co-creation. Building on previous research of inter-organizational governance, relational contracting and Public-Private Partnerships, this study shows that relational governance with its elements of relational norms and partners' trust acts as a mediator between contractual governance and partners' contributions leading to project performance. According to the study findings, relational governance elements are suggested to operate as compensators of contractual governance, while contractual governance partially enables the operation of relational norms and the emergence of trust. This raises new research challenges such as defining the extent to which relational governance can be intentionally designed, how cross-project governance factors 

ROLE OF RELATIONAL NORMS, TRUST AND PARTNERS' CONTRIBUTION

have an impact on governance at the project level, and how the interplay between relational and contractual governance is (re)constituted over the life-cycle of a PPP project. 


\section{CONTRACTUAL AND RELATIONAL GOVERNANCE AS POSITIONED- PRACTICES IN ONGOING PUBLIC- PRIVATE PARTNERSHIP PROJECTS}

\section{ABSTRACT}

This chapter introduces a process framework based on the realist social theory for studying governing in ongoing Public-Private Partnerships (PPPs). Contractual and relational practices are defined as activities enacted and re-created by virtue of actors' dual positions: at both the partnership and the parent organizational levels. In PPPs, complementarities and contradictions between public, rule-bureaucratic logic and private, market-oriented logic define structural demands on actors. Nonpredictive and innovative governing activities emerge from the actors'reflexive capacity to balance different demands. The framework allows the examination of the complex interplay of relational and contractual practices, illustrated in a PPP Dutch case.

Keywords: Public-Private Partnerships - Positioned-Practices - Project Governance - Contractual Governance - Relational Governance

\footnotetext{
${ }_{14}$ Published as Benítez-Ávila, C., Hartmann, A., \& Dewulf, G. (2019). Contractual and Relational Governance as Positioned-Practices in Ongoing Public-Private Partnership Projects. Project management journal, 8756972819848224.
} 


\section{$2.1 \quad$ INTRODUCTION}

Because traditional project management approaches overlook the emergent nature of projects, the turn to social theories is a promising but unexplored alternative for extending our understanding of the actuality of projects (Floricel et al., 2014). This also applies to project governance, where the intense focus on economic and behavioural theories has provided little room to account for the complexity and dynamics of governing practices (Brunet, 2019). There is, in particular, a lack of alternative conceptualizations for the interplay between contractual and relational governance activities in projects. Governance scholars have mainly framed the interplay as either a substitutive or complementary one and, by doing so, have reduced it to two "mutually exclusive phenomena in terms of what they are, why they form, and how they are related" (Huber et al., 2013, p. 83). Such an understanding does not give space to disentangle the array of interrelated governing actions, puts innovative interaction between brackets, and ignores the possibility that governing activities reshape governance structures (Sanderson, 2012).

This chapter aims at developing a process framework for studying the interplay between contractual and relational governance in ongoing public-private partnerships (PPPs), using as a canvas the meta-theorization of the interplay between agency and structure developed by realist social theory (Archer, 1995; Bhaskar, 1998; Reed, 2001). Rather than being a choice between two discrete forms of governance made by calculative actors, this theoretical perspective allows us to frame relational and contractual governance as emerging practices during the interaction of individuals in PPP projects filling organizational and social positions. The proposed framework of PPP governance as positioned-practices builds upon Archer's (1995) morphogenetic approach in light of private and public organizational logics (Rufín \& Rivera-Santos, 2012) and the prevalent multilevel view of project governance (Ahola et al., 2014; DeFillippi \& Sydow, 2016; Turner \& Müller, 2003). It suggests that individuals in PPP projects execute contractual and relational activities predisposed by a layered governance structure. While the structural complementarities and contradictions at the project level predispose public and private actors to interact through logics of compromise or solidarity, the contingent relationship outside the partnership predisposes the same actors to engage in modes of interaction ranging from competition upon contradictions and opportunism upon complementarities. In a continuous effort to find ways to avoid the consequences of not complying with the structure of trust/control relations attached to their different roles, managers enact and re-create contractual and relational governing activities in a creative and nonpredictive way.

The framework shifts the attention from the static functional (dysfunctional) relation between two discrete forms of governance to prevent opportunistic behaviour in projects to the dynamic activity of inventive actors addressing the inconsistent and conflicting demands placed on them by their positions. This opens up the opportunity to explain the emergence of creative and sometimes paradoxical combinations of relational and contractual practices as the outcome of divergent demands from the horizontal relationship at the project level and the hierarchical relations in their own organizations. In dealing with multiple and competitive demands, governing practices partially reshape the governance structure in place and actors' expectations over time. States of complementarity and substitution between contractual and relational governing activities emerge from the underlying 
managerial struggles of actors to resolve multiple expectations attached to their roles, in the cycles of change or reproduction of the system of project rewards, penalties, and beliefs.

In order to develop the framework, the extant literature on relational and contractual governance is reviewed to illuminate the overemphasis on the ex-ante configurations of governance structures upon risk allocation, and the poor conceptualization of the governing process during the actual execution of PPPs. The second section introduces the realist social theory and the morphogenetic cycle as an alternative point of departure for studying the complexity of relational and contractual governance in PPPs. It makes a conceptual differentiation between compliance-oriented and trust-oriented governing activities as events emerging from actor interactions in the present, and the governance structure of interest, resources, powers, constraints, and predicaments inherited from previous cycles of interaction (and also susceptible to be transformed/reproduced in the future). On this theoretical basis, the third section elaborates the process framework for the governance of PPP projects by clarifying the expected interactions and predispositions of managers, given their dual role at the partnership level (horizontal) and the parent organizational level (vertical). The fourth section presents the case of a PPP project for a military facility in the Netherlands to illustrate the potential of the proposed process framework for understanding the changing stages of contractual and relational governing practices during PPPs. The final discussion highlights the contribution of realist social theory as an alternative theoretical lens to our procedural understanding of governing activity and governance structure change in temporary organizations (Bakker, DeFillippi, Schwab, \& Sydow, 2016).

\subsection{CONTRACTUAL AND RELATIONAL INTERPLAY IN PPPS}

The emergence of public-private partnerships as one of the pillars of contemporary public management is paradoxically linked to an ambiguous definition by scholars. The debate regards the extent to which PPPs involve political, economic, and managerial dimensions of a phenomenon not reducible to a simple project delivery agreement (Hodge \& Greve, 2007, 2010, 2017). Among the alternatives to organize the relationships between public and private organizations (Kivleniece \& Quelin, 2012), most prominent is the transfer of typical responsibilities (and risk) to the market by means of long-term contracts (Hodge \& Greve, 2017). Accordingly, PPP research has focused on the exante contract design and risk allocation for reaching project performance, given diverse organizational objectives (De Castro e Silva Neto et al., 2016). Value for money (VfM) proves to be the primary public objective represented by the procurement authority, while return on investment is the objective of the sponsors, and repayment is the objective of the lender (Grimsey \& Lewis, 2002, 2005). To guarantee VfM, return on investment, and repayment, decision-makers have a range of possibilities to address risks. Solutions include sharing risk, negotiating risk, transferring risk, or defining contingent risk rules (Cruz \& Marques, 2013; Davies, Frederiksen, Dewulf, Taylor, \& Chinowsky, 2010). Potential conflicts can be offset by allocating responsibilities and incentives to the actor in the best position to deal with risk (Bing et al., 2005; Chang, 2013; Johnston \& Gudergan, 2007).

The theoretical study of PPP has been inspired by the fundamental proposition of static alignment, according to which "the choice of organizational forms involves matching formal structures or 
strategies, exchange conditions, and environments in some discriminating way" (Zenger et al., 2000, p. 290). Scholars conceptualize PPP contracts as a hybrid organization, whose suitability depends on adequate project risk allocation between private and public actors. For example, according to incomplete contract theory, the private organization should retain asset ownership by default, given its stronger incentives to introduce cost reduction. However, noncontractible qualities of the public service are susceptible to deterioration as a result of private incentives for cost reduction, and therefore, their control should be retained by the public organization (Francesconi \& Muthoo, 2006; Hart, 2003; Hart, Shleifer, \&Vishny, 1996). Inspired by transaction cost economics, Kivleniece and Quelin (2012) suggest that public and private partners have to make a front-end choice along a continuum between integrative and autonomous PPP organizational forms, which leads to collaborative versus supervisory modes of interaction (S. Wang \& Bunn, 2004). The appropriate mode of governance will be determined by internal and external project idiosyncrasies. From a private actor's perspective, the integrative model of governance with an emphasis on close collaboration will then be more suitable in the presence of high uncertainty from the market, technological change, or high exposure to social activism from stakeholders (Kivleniece \& Quelin, 2012).

Elaborating on the assumption of self-oriented and bounded rationality that encourages parties to assume opportunistic behaviour, relational governance is seen as an alternative for stabilizing mutual individual expectations in the process of value co-creation (Bachmann, 2001; Edelenbos \& Eshuis, 2012; Scott, 2013). Contractual and relational governance use different mechanisms for dealing with the natural inclination toward devious behaviour, leading to a more predictable exchange by absorbing conflicts and reducing uncertainty (Edelenbos \& Eshuis, 2012). Contractual mechanisms are based on control enforced by ownership and authority, while relational mechanisms are based on trust and positive expectations of collaboration or social sanctions (Henisz et al., 2012).

Departing from their different nature but potential equivalence in safeguarding the integrity of transactions, organizational studies inspired by economic thinking have used the complementarity/ substitution dichotomy as the primary conceptual frame to study the interplay of contractual and relational governance (Poppo \& Zenger, 2002). Based on this conceptual frame, scholars have aimed at defining the conditions under which the use of one type of governance increases or decreases the functionality of the other respecting the outcomes of the transaction (Zenger et al., 2000). However, empirical evidence is rather contradictory in terms of whether contractual and relational governance mechanisms act as substitutes or complements. Only recently have scholars started to conceptually and empirically explore the dynamic interplay of governance mechanisms and the materialization of their idiosyncratic relations over time (Cao \& Lumineau, 2015; Howard, Roehrich, Lewis, \& Squire, 2017; Huber et al., 2013).

Although the relationship between public and private actors is critical for the success of a PPP, it is also challenging to deal with (Kumaraswamy, Zou, \& Zhang, 2015) and more often resembles a leader-follower relationship than a partnership (Shi, Chong, Liu, \& Ye, 2016). There are key operative and administrative differences between public and private organizations that allow value-creating opportunities, but also bring additional confusion to the inherent dilemmas when compromising specific and sunk investments (Scott \& Triantis, 2005; Villani et al., 2015). While a permanent feature of private organizations is their profit-oriented and competitive-driven nature (Villani et al., 2015), policy 
outcomes shaped by sociopolitical interests drive the operation of public organizations (Mahoney, McGahan, \& Pitelis, 2009). Procedural rigidity, responsiveness to stakeholders, and intense scrutiny not only put public officials at higher levels of risk aversion compared to private managers but also impose restrictions on the development of close and informal relationships between public and private officials, in order to avoid accountability and transparency concerns (Ke et al., 2013; Ling et al., 2014; Rufín \& Rivera-Santos, 2012). Private organizations regard public accountability requirements as bureaucratically burdensome and as "red tape," which can create financial difficulties for the firm when public procedures result in obstacles for payment delays (Rufín \& Rivera-Santos, 2012). Different logics of public and private operation confront individuals in PPPs with competing demands (Villani et al., 2015), shaping a multilevel structure of project governance (Ahola et al., 2014; Turner \& Müller, 2003). When people work together on projects, they bring different "identities," including their individual identity, their collective project identity, and their organizational membership (Sydow \& Braun, 2017). This can create tensions of loyalty through conflicting cultural norms and work expectations that project participants bring with these identities (DeFillippi \& Sydow, 2016).

In order to address the complexity of multiple organizational logics, cultures, and interests in project work, the discussion of the interplay between contractual and relational governance mechanisms has been reframed in the broader perspective of structure and agency (Cicmil \& Marshall, 2005; Floricel et al., 2014; Sanderson, 2012). It has been shown that relational aspects and trust are emerging in a process of joint and gradual sense-making on the nature of a relationship (Bygballe et al., 2015) and that contractual forms do not necessarily have a direct relationship with PPP performance (Klijn \& Koppenjan, 2016). However, trust mediates this relationship along with relational norms and the partners' mutual contribution (Benitez-Avila, Hartmann, Dewulf, \& Henseler, 2018). In other words, contractual and relational governance mechanisms are mutually constituted over time to grapple with the multilevel identities of project participants (Bygballe et al., 2015). PPP governance becomes a process of interacting agents adjusting the actual operation of formal and informal structures by giving meaning to their work and relationships, supported by social scripts of social behaviour (South et al., 2018).

The notion of mutual constitution of structure and agency was introduced by Giddens (1976) structuration theory. It states that activities only have the meaning agents ascribed to them, but these agents are limited and enabled by the structural context (Cruickshank, 2007). As agents can rework those circumstances, "structuration of social practices is to seek to explain how it comes about that structures are constituted through action, and reciprocally how action is constituted structurally" (Giddens, 1976, p. 161). Structuration theory is an appealing alternative to the economic frame of contractual and relational governance interplay (Sanderson, 2012), suggesting that informal aspects of governance and governing activity emerge and also reshape formal structures(Brunet, 2019; Bygballe et al., 2015). However, the suitability of structuration theory has been under some scrutiny in the sociological debate (Archer, 1995). It is particularly the "duality of structure" argument, according to which "structure is both medium and outcome of the reproduction of practices" (Giddens, 1979, p. 69), that has been criticized. The duality of structure implies that agency and structure are "two sides of the same thing" (Archer, 1995, p. 88), which makes it impossible to study the process that links external constraints and what people actually do, and leads to voluntarist explanations of social reality where structures are synonyms for the "practices which agents chose to repeat" (Cruickshank, 2002, p. 86). It 
provides insufficient guidance for specifying how structural relations between diverse organizational roles and identities of project participants predispose specific types of interaction in the process of sense-making and lead to contractual and relational governing activities.

\subsection{REALIST SOCIAL THEORY FOR STUDYING GOVERNING ACTIVITY}

From the perspective of realist social theory, the explanation of human interaction must clearly define building blocks in relation to structure or agency as different levels of reality (Archer, 1995). The points of contact between human agency and social structures are the so-called positionedpractices (Bhaskar, 1998). These are activities that individuals can engage in by virtue of their position (e.g., places, functions, rules, tasks, etc.) (Archer, 1995; Reed, 2001). "Positioned-practices provide the crucial link between structure and agency by establishing a mediating system of tasks, activities and relations through which material conditions and individual actors are brought together in sustainable institutional forms" (Reed, 2001, p. 216). Enforcing a contractual clause, renegotiating contracts, or bringing together diverse stakeholders for discussing a project issue are positioned-practices. In this regard, there is a structural dimension of governance that is analytically different (and preexistent) to the particular governing actions that people enact and reproduce based on their positions. Governing agency and governance structure are "existentially interdependent but essentially distinct" (Reed, 1997, p. 30), implying that their interplay is only understandable over time.

\subsubsection{Governance Structures and Situational Logics}

Societies and organizations are organized by slots of positions, such as father-son, landlord-tenant, employer-employee, public partner-private partner (Fleetwood, 2004). For example, enforcing a contract clause by a person is only possible by virtue of the position that he/she fills as an employer and in relation to the person who is filling the position of the employee (Bhaskar, 1998). Therefore, social and organizational structures are relational, as they exist as result of agents entering into relations (Fleetwood, 2004). At the most basic level, structures "are expressed in certain structured interests, resources, powers, constraints and predicaments that are built into each position by the web of relationships" (Reed, 2001, p. 215). As these positions operate independently of the psychological drivers of people's behaviours, there are objective relations and emerging properties between positions and their related systems of penalties, rewards, and beliefs (Archer, 1995). Furthermore, the operation of some positions might facilitate or impose difficulties in the operation of other positions in the extent to which the attached systems of rewards, penalties, and beliefs are in contradiction or complementarity. As a consequence, these positions not only define a script of activities to people, but also the chance to "work together" upon their vested interest (Archer, 2011). A governance structure includes the specific configuration of positions with their attached systems of rewards, penalties, and beliefs, and even more important, the emerging relations between these positions that predisposed people to guide their interaction with higher or lower levels of control and trust (Reed, 2001).

Archer (1995) coined the concept of situational logic for referring to the emerging properties of the relations between different systems of rewards, penalties, and beliefs. Structural positions are related 
to one another either in a complementary or contradictory fashion, if their system of penalties, rewards, and beliefs is mutually reinforcing or incompatible. While the definition of logical relations of contradiction and complementarity used by Archer has certain parallelism with work on institutional logics (Mutch, 2007), her innovative insight is the introduction of transcendental reasoning as a second axis to understand interactional predispositions among actors fulfiling social and organizational roles. Therefore, complementary or contradictory relationships between systems of penalties, rewards, and beliefs can be related in either a necessary or contingent fashion. Necessity "only states that X cannot be what it is without certain constituents A, B, C, N' and the relations between them" (Archer, 1995, p. 174). For example, a partnership between public and private organizations implies a necessary relationship between the rule-bureaucratic logic of public organizations and the profit-oriented logic of private organizations. Then, a PPP cannot be without these constituents, which allow value co-creation and at the same time generate tensions among the people who are filling roles in the partnership. Contingency refers to the situation where X can be related to A, B, C, N', but leaves aside those relations that do not compromise the existence of $\mathrm{X}$ itself. For example, as parent organization, a public authority can organize its operation relying on the profit-oriented logic of the private sector, without compromising its existence as a public organization. The configuration of structural relations between social and organizational positions along the necessity-contingency axis and complementarycontradictory axis shapes four types of situational logic that predispose actors to different modes of interaction (Archer, 1995).

1. The situational logic of correction emerges from the contradictory relation between the system of penalties, rewards, and beliefs of positions that are related in necessary fashion. This situational logic predisposes actors to engage in interactions aimed at containing others' interests while making concessions to correct the structure of their relation.

2. The situational logic of protection emerges from complementarities between the system of penalties, rewards, and beliefs of positions that related in a necessary fashion. In this situational logic, actors are pre-disposed to guide their interaction by solidarity and collaboration, reproducing the structure of their relations.

3. The logic of elimination emerges from the contradiction between the systems of rewards, penalties, and beliefs attached to positions related to one another in a contingent way. This logic predisposes actors to engage competitive modes of interaction, pushing for structural change.

4. Finally, the situational logic of opportunism emerges from the complementarity relationship between the system of penalties and rewards is attached to positions that are contingently related to each other. This situational logics predisposes actors to base their interactions on the exploitation of the potential gains, leading to structural differentiation and change.

\subsubsection{Governing Activity: Positioned-Practices and Reflexivity}

When an individual assumes a position as an actor in the web of relationships, it is expected that he/she will follow the script of behaviours attached to that position with respect to others (Archer, 1995). In consequence, the condition of possibility to enact/produce any activity in a specific situation is given by the vested interest attached to the role, and the emerging situational logic that brings together different organizational positions in the situation at hand. Likewise, relational and contractual activities are events that emerge in day-to-day working life, which materializes the repertory of 
possible actions aligned to vested interests and consequent situational logics between different positions. Relational governing activity refers to events of reciprocal social exchange based on trust, such as open communication, which are structurally predisposed by situational logics of commitment or solidarity. This predisposition is independent of the personal or psychological inclinations of the person filling that organizational or social position. Compliance-seeking activities such as enforcing contracts are predisposed by a mode of interaction where material/political interests are in tension, independent of individuals' egoist or altruist disposition (Reed, 2001). Naturally, there is a scope of discretion to engage in practices in various ways, and people can even invent new practices. They must, however, be consistent with the position filled; not any practice goes (Fleetwood, 2004). In this regard, structural predisposition is neither fate nor a mechanical behavioural force. Actors experience a premium to enact/produce activities that are consistent with their roles and situational logic where they are embedded, as well as an opportunity cost to enact/produce activities that differ from these predispositions. However, "actors could then conform to the conditioned action, diverge and accept the cost, or even display an inventive capacity and circumvent the constraints posed by structures" (De Vaujany, 2008, p. 55).

The reflexive properties of human beings mediate structural predispositions and the actual enactment/ production of social or organizational activity. Agency conceptualized from the critical social realist perspective focuses on the assessment of circumstances and ends, rather than the maximization of means for objectives (Caetano, 2015). In principle, actors are motivated to act in their interest, which is a function of their social and organizational positions. However, in a particular working situation, the enactment/production of relational and contractual governing activity is the result of people reflecting on the predispositions emerging from structural complexity, and prioritizing personal or professional concerns during interaction with their counterpart. Contractual and relational "events" are purposive actions with meaning in executing alliances, countermobilizing resistance, making compromises, concessions, and even imposing will on others. Individual reflexivity "not only mediates the impact that structures have on agents, but it also conditions individual responses to particular social situations" (Caetano, 2015, p. 62). The reintroduction of the sense of self in the network of positioned-practices is fundamental to explain the actual emergence of observable governing activity during interactions (Archer, 2003).

Realist conceptualization establishes different sources of people's concerns, which guides their reflexivity assessment. At the most basic level, human concerns are "those of physical well-being in relation to the natural order, performative competence in relation to the practical order, and self-worth in relation to social order" (Archer, 2011, p. 88). These concerns are not necessarily articulated in a harmonious way, and they often confront us with dilemmas in our day-to-day human experience: "cessation of an activity in response to boredom in the practical domain can threaten physical wellbeing by leaving a task unfinished, and withdrawal as response to social shaming may entail a loss of livelihood" (Archer, 2011, p. 88). When people assume social and organizational roles, these basic concerns increase their complexity in such a way that "human agents are seen as necessarily located within, and both constrained and empowered by, a plurality of competing and contradictory social structures which often place inconsistent and incoherent demands on them" (Reed, 2001, p. 2015). Therefore, relational or contractual activities in working interactions cannot be fully explained without the mediation of the specific people considering and prioritizing different sources of concerns linked 
to different organizational demands. The enactment of governing action entails "both judgments of worth and the assessment of whether we care enough to be able to live with the cost and tradeoffs involved" (Archer, 2011, p. 89). In general, what emerges as an observable governing event is the contingent combination of different structural dispositions and agential reflexivity that happen to co-manifest themselves.

\subsubsection{Cycles of Interplay and Levels of Change}

The research agenda of realist social theory defines how organizational relations and positionedpractices are ever susceptible to change at the macro-perspective level, i.e., at the level of social systems (Archer, 2011). Rather than appealing to external intrusions, the driver of change is the endogenous struggle of actors to maintain or improve their relative positions, reshaping or reproducing the structure of relations where they find themselves (Archer, 1995). Structural change emerges from their innovative capacity in reshaping initial constrictions and regrouping actors in new coalitions when they interact upon different situational logic. Archer uses the term morphogenesis for describing this systemic change, which implies new systems of penalties, rewards, and beliefs, and a change in the role array and the very life changes of different sections of the population assuming new positions in society (e.g., the actual possibility that women as a segment of the population enjoy full citizen rights such as voting) (Archer, 1995). On the other hand, morphostasis refers to the reproduction of the existing parts of the social order.

Archer (1995) proposes to elaborate the analytical histories of the emergence of new structures, consisting of three parts of a cycle: (T1) structural conditioning, (T2-T3) social interaction, and (T4) structural reproduction or elaboration leading to a new cycle. As an epistemological implication, the identification of cycle intervals is the business of specialized researchers. Systemic morphogenesis can only be explained as a diachronic narrative of the interplay between structure and agency, where (T4) is explained by virtue of (T2-T3) predisposed by (T1). Researching the present or synchronic relations between agency and structure at the societal level focuses on the morphostatic account of how structures are sustained by actions, and also the identification of actions that are intended to change the status quo but have not yet succeeded in doing so (Archer, 2011). In fact, the explanation of why a social structure endures has to do with adaptations in its constitution, retaining "key relational properties and causal powers without it remaining the same entity" (Archer, 2011, p. 69).

If it is true that a radical change in structural control and trust relations implies the study of macrosocial dynamics, the occurrence of particular governing events in any organizational context is the outcome of causal properties of the macro and micro level. Hence,"stratified interconnections between micro-level and macro-level social mechanisms are fundamental to an explanation of the trade-offs between trust and control in specific organizational situations" (Reed, 2001, p. 203). Observed patterns of contractual and relational activities result from the interaction between the structural conditioning domain and the creative social action domain, resisting complete codetermination. This analytical difference between structure and agency furnishes a dynamic conceptualization of governance phenomena, where the governing activity in the present is predisposed by the governance structure inherited from the past, but susceptible to be transformed for future cycles of governing activity. Realist perspective recognizes trust and control as structural properties with relative durability at the structural 
level, given the configuration of different organizational and societal roles. They are, however, subject to contingency and innovation at the agency level where different organizational roles and demands operate upon the reflexive capacity of individuals to provide meaning to trust-based activities and compliance-based activities.

\subsection{TOWARD A PROCESS FRAMEWORK OF GOVERNING ACTIVITY IN ONGOING PPPS}

The fundamental tenet of the theoretical perspective presented here is the need to introduce time as the element for organizing the cycles of the interplay between governing agency and governance structure. Considering that macroscopic social change unfolds along the cycle (T1) structural conditioning, (T2-T3) interaction, and (T4) structural morphogenesis or morphostasis, a process framework of PPP governance should outline the extent to which positioned-practices change through the endogenous dynamics of the partnership and the exogenous social dynamics. The starting point examines what is susceptible to change endogenously by virtue of the interaction of actors in a project. A complete morphogenetic cycle of public policy change cannot emerge from a single project. This does not mean that policy structures and parent organizations as structural entities have to be taken as static, but their change is mainly exogenous to the project level. The activities in one PPP project have a marginal effect on the structural configuration of public infrastructure policy or the infrastructure industry. Therefore, what is susceptible to change as the result of the interaction between actors in a project are the rules defined by formal agreements (partially), the material conditions of the source of value upon which parties engage in a partnership, the levels of interpersonal trust, and the practices for complying with the role assumed (within the structural boundaries). These elements must be deployed at the duality defined by the temporal but necessary relation between public and private positions at the project level, and the permanent but contingent relation between public and private positions at the organizational level. Hence, the dynamics of project governing activity are defined through micro-cycles of practices enacted or re-created (T2-T3), while the change of project governance structure includes the macrocycle $(\mathrm{T} 1 \rightarrow(\mathrm{T} 2-\mathrm{T} 3) \rightarrow \mathrm{T} 4)$.

In (T1), there are two organizational entities with certain interests defined by their own logics of operation connecting resources, rewards, penalties, and beliefs in a hierarchical structure of positions. These two entities are related in a contingent way, meaning that the operation of their logics is independent of their counterpart. However, they engage a contractual relationship upon their potential performative complementary for the delivery of public services (Rangan et al., 2006), relying on institutional systems operating at the societal level (market, policy, and justice system). The negotiation of a PPP establishes a necessary relation between the private and public organization, from an initial compromise between different logics of operation (profit-oriented versus rule-bureaucratic-oriented) (Rufín \& Rivera-Santos, 2012; Villani et al., 2015). The new relation defined by the contract brings together not only complementarities in a necessary fashion but also contradictions. These relations are reshaped in the contractual form, as a result of the cycle of interaction between decision-makers during the procurement and contract-crafting process acting under market, policy, and legal enablers 
and constrictions. The contractual system of penalties and rewards formally define the temporal system of rules, roles, and activities that mediate the process of value creation and capture and the interest of people filling organizational and project positions. The contract introduces a fundamental transformation in the nature of the relationship between organizations, establishing expectations for value co-creation and capture at the front end of the project.

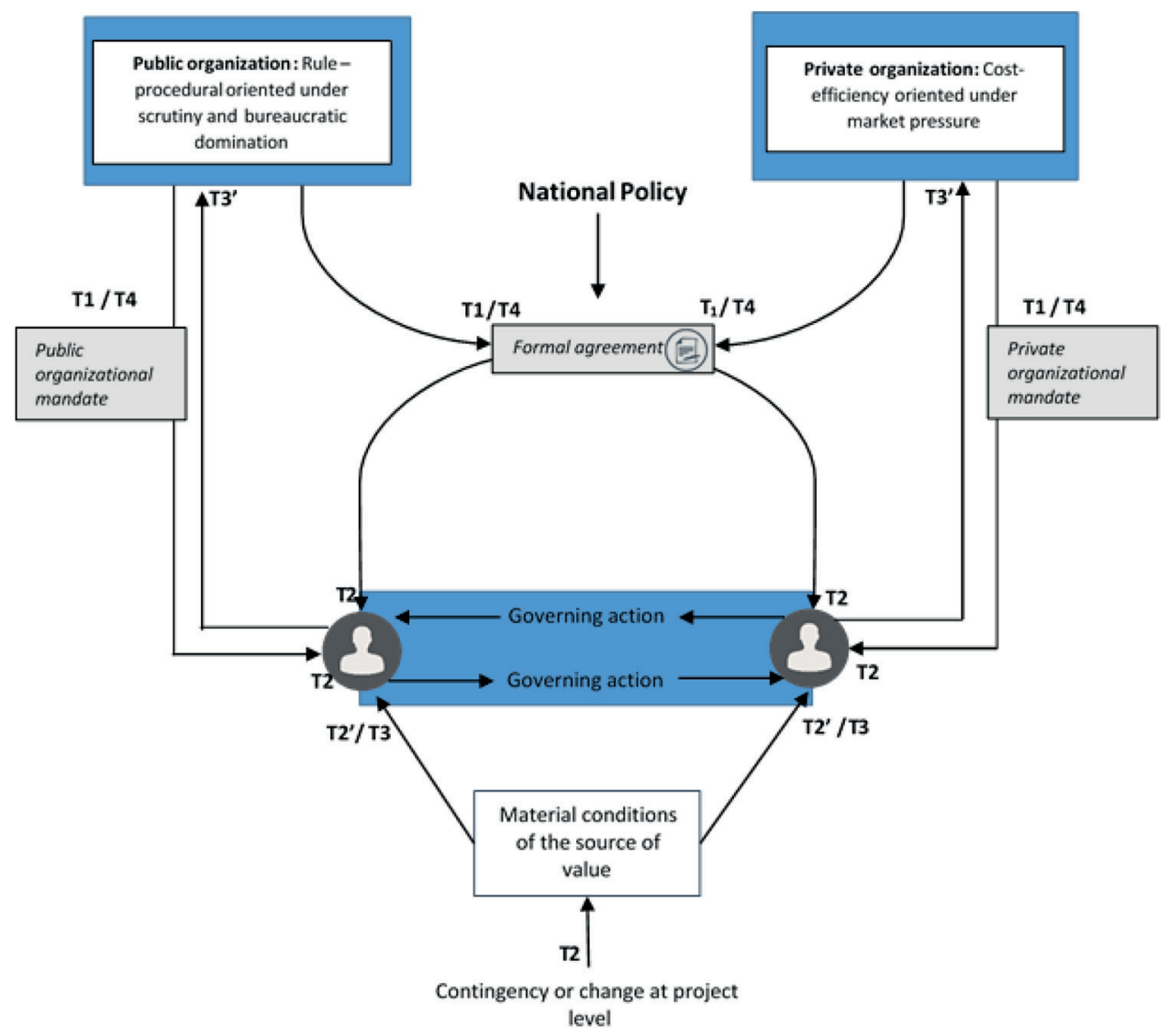

Figure 2.1 Process framework of governing activities in PPPS

In (T2-T3), governing interaction is predisposed by structural degrees of complementarity and contradiction in $\mathrm{T} 1$ at two levels: between the logic of operation of parent organizations as independent entities and the logic of operation of the partnership as a singular but temporal entity. The need to integrate the work contribution at these two levels implies diverse demands (Braun, Ferreira, \& Sydow, 2013; DeFillippi \& Sydow, 2016; Sydow \& Braun, 2017), emerging from the contingent relations between permanent organizations (vertical) and the necessary relationship between public and private operations to reach the mission of the partnership (horizontal). Structural predispositions define the boundaries of the possible governing practices that can be enacted/created, and the opportunity cost of deviating from these scripts. Table 2.1 theorizes the modes of interaction between PPP actors and governing activity predisposition (engaging in reciprocal-trust or control-compliance governing activities). 
Table 2.1 Predisposition of Reciprocal Trust/Contractual Control Activities T1 $\rightarrow($ T2-T3).

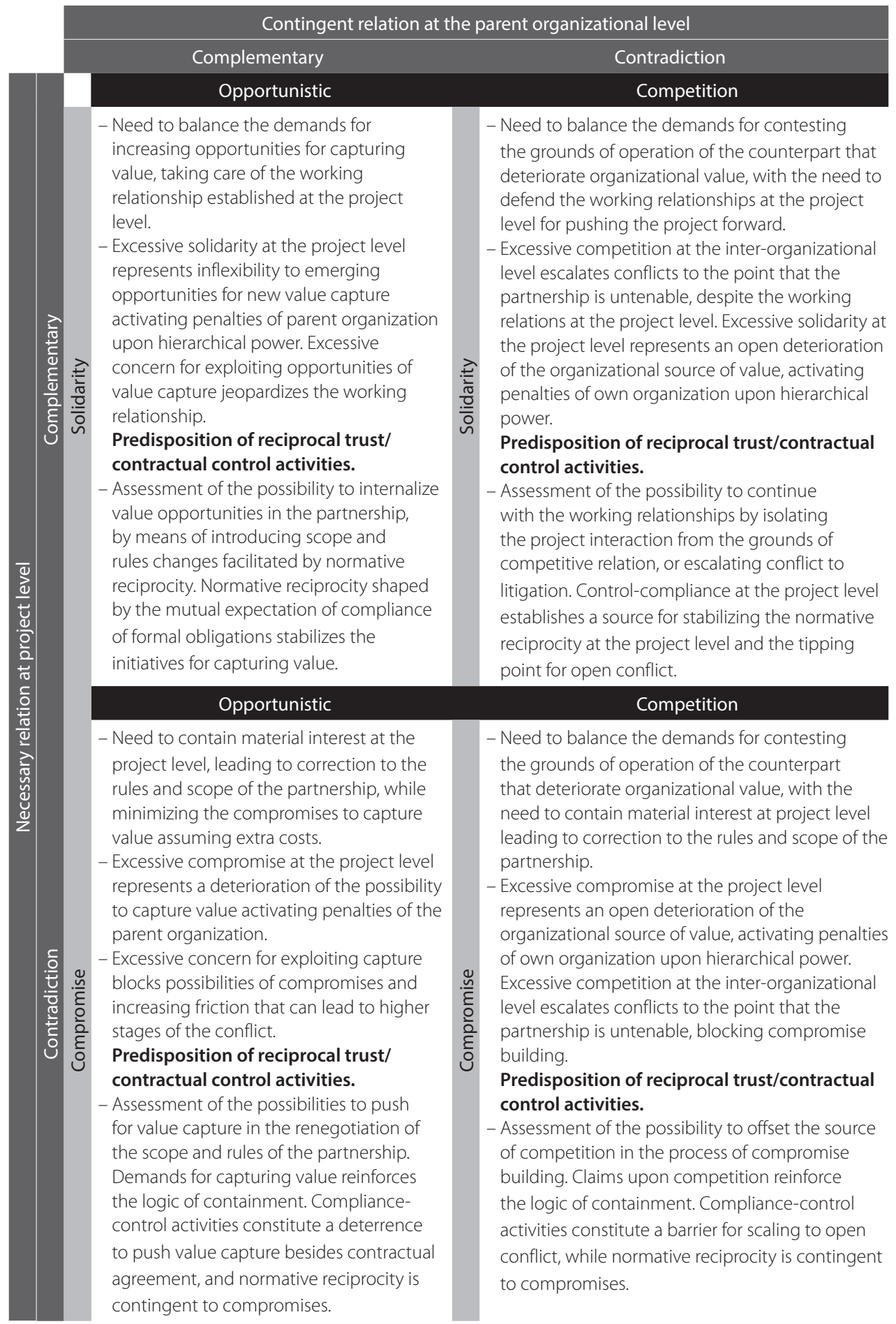


Cycles of governing activity lead to (material) changes in the source of value, which accentuate or attenuate existing complementarities or contradictions at the project and inter-organizational level. The interaction at the project level can be triggered by a contingent event affecting the programmed functionality of the asset/material source of value of the partnership, or by the programmed life cycle process of the project (T2). Partners mutually monitor the expected functionality of the asset/source of value and the implications for the ongoing level of contradiction or complementarity in the operation of the partnership and the operation of the parent organization (T2'). From the initial monitoring effort, project actors define concerns based on the objective advantages and disadvantages of actions available by their positions (Caetano, 2015), using their deliberation to engage practices such as enforcing the contract as a power-induced compliance activity to control others' actions, or carrying out relational activities based on trust and reciprocity.

The sequence of governing actions signalizes the actors' intentions to the counterpart shaping the interaction loop in T2-T3 and provides meaning to the situation in terms of solidarity, competition, concessions, or opportunism. This meaning is also related to the effect of contractual and relational activities in the functional status of the asset, which ultimately defines value for the organizations in the partnership. During the interaction, managers reflect on the material consequences of their governing activities and the extent to which the path of interaction might trigger penalizations (or miss rewards) from the hierarchical structure of their organizations, or in the day-to-day interaction with their project counterpart. Under the described logic, the interaction reinforces or dampens the initial structural predisposition, changing the cost of opportunity of the repertory of governing activities available to the actors' positions.

The end of the cycle (T3) is defined by a closure of the problematic issue, emerging from the evaluation of the (material) stage of the asset/source of value. The closure can also be defined by the programed transition of one phase to the other, following the regular life cycle process (e.g., the transition from construction to operation). The dual role of managers implies that their interaction with their counterparts at the project level requires being aligned with the hierarchical structure of their organizations. This means that the manager herself/himself mediates the consequence of the interaction at the project level with the parent organization ( $\mathrm{T}^{\prime} \mathrm{C}^{\prime}$. Additionally, it is a matter of contingency if the managerial reflection indicates that a formal provision requires clarification or modification. Formal modifications are triggered by the interaction between managers but are mediated by the oversight mechanisms at the parent organizational level. Then, the final part of the cycle (T4) implies the change or reproduction of the original structural conditioning at the level of organizational mandates for the project and at the contract level (scope of rules).

\subsection{ILLUSTRATIVE CASE}

In order to illustrate the shortcomings of the prevalent interplay conceptualization and how the developed framework can provide more insightful explanations into the dynamics of PPP governance, we make use of a case on a PPP for a military facility in the Netherlands organized as a design, build, finance, maintain and operate (DBFMO) project. We are particularly interested in the interaction 
between the public contract manager and the private facility manager during the introduction of functional changes in the exploitation phase of the project. Their collaboration in the project involved a path of contractual and governing practices that appear to be paradoxical from the dichotomous perspective of the interplay between governance mechanisms (Poppo \& Zenger, 2002), making the case an appropriate empirical setting to explore the conceptual framework developed upon the tenets of realist social theory.

\subsubsection{Approach and Methods}

The case identification and selection took place during the involvement of the first researcher in an initiative for raising the awareness of the PPP practitioners about the complexity of introducing changes in the exploitation phase of DBFMO projects. In this regard, the research activity followed the principles of action research, which aims at creating scientific knowledge while solving a relevant social or organizational problem (McKay \& Marshall, 2001). The initiative was led by a PPP professional network in the Netherlands, which supports knowledge transfer between DBFMO projects. The researchers were asked to elicit lessons from DBFMO projects during their exploitation phase, in order to provide inputs for a one-day conference of the network on cooperation in PPPs. In action research, a distinction should be made between the problem-solving interest and the research interest (McKay \& Marshall, 2001). Accordingly, the scientific interest focused on the analysis of a military facility project, regarded as an emblematic case of collaboration in the PPP professional network. During the interaction with the managers of the project, the researchers found that current levels of collaboration implied a rather complex path of learning, with different emphasis on contractual and relational governing activities over time. This idiosyncratic configuration provides grounds for the selection of this case as a paradigmatic one (Flyvbjerg, 2006).

The data collection and analysis were conducted as an iterative process in two workshops and four interviews with practitioners involved in the case. For the two workshops, the first researcher used the group model building (GMB) technique with causal loop diagrams (CLDs) (Vennix, 1996) to elicit practices to deal with the introduction of functional changes. This technique was chosen because it allows the identification of complex relationships among variables, triggers participants to explain these relations over time, and fosters learning, communication, shared vision, and commitment between teams (Vennix, 1996), stakeholders (Van den Belt, 2004), or the community of practitioners(Hovmand, 2014). Specifically, the GMB activity provided a space for reflecting on the process of introducing contractual changes and the dynamics of contractual and relational practices in this process. An initial CLD model was set up by the researcher based on organizational charts describing the contractual process for introducing functional changes for the operation of the two projects, the opinions of PPP network consultant about the frequent challenges faced by managers, and existing literature on the management of DBFMO projects in the Netherlands. In the first workshop, the CLD was discussed and rebuilt by four attendees, including the public and private manager of the selected case, the PPP network consultant, and a public manager of the second project. Between the workshops, face-toface interviews with the workshop attendees were conducted to reveal whether the model reflects the dynamics of working practices for introducing changes from the practitioners' perspective. In the second workshop, the extent to which the CLD reflected the working practices according to face-toface interviews and captured the insights on how the relationship and working dynamics changed 
over time (validation of results) was discussed in a group setting. Because the CLD resulting from the workshops and interviews comprised more than 30 loops, the authors analytically abstracted the case governing activity in the final CLD included in this chapter (see below Figure 2.2 PG 55). This final CLD, along with the explanatory narrative, was shared with managers and consultants as a final step of validation.

\subsubsection{Functional Change as a Triggering Event}

DBFMO contracts establish a clear differentiation between the role of public contract manager and private facility manager in the introduction of functional changes during the exploitation phase. While the former must define required changes in terms of functional specifications (e.g., working environment for 100 new staff), the latter must define the best means for meeting these specifications considering life cycle cost, financial implications, and emerging risk (e.g., characteristics of the physical space, furniture, services, etc.). According to practice in the Netherlands, two particular difficulties lead to friction and frustration between public and private managers when introducing changes to the operation of assets procured by DBFMO contracting. First, establishing functional specifications turns out to be rather abstract compared to the traditional practice of contracting goods and services, eliciting discussions about roles and actual necessities. Second, the price submitted by the private facility manager usually triggers scepticism from the user. Reactions such as "I can have this change cheaper when I refurbish my own house" are not only a symptom of incomprehension about the essence of DBFMO projects, but evidence of the interest to counteract the DBFMO regime by the user.

\subsubsection{Governing Activity}

In order to face these two difficulties emerging from the DBFMO contractual arrangement, the public contract manager and the private facility manager of the selected case made a careful effort to make sense of their contractual roles and responsibilities, given the increasing pressure of user requirements and the regime of DBFMO penalties. This process of sense-making was promoted by the mutual aknowledgment that the project was one of the first DBFMO contracts in the Netherlands. It involved an extensive discussion on the scope and implications that functional specifications rule as well as the criteria for establishing reliable life cycle cost during the operation phase. At the beginning of this phase, the team introduced dialogues as informal activities to jointly translate the requirements of the user in output specification and discuss input specifications and life cycle cost in detail. In the dialogue, managers agreed to place between brackets the contractual principle according to which the public manager should deliver output specifications of the change, in a context where contractual roles were not totally clarified and appropriated, leading to delay and frustration. According to the public contract manager:

In year one we had a lot of dialogue about things, because we didn't ask for functional specifications, we asked for the solutions. At the beginning we had a lot of frustration, delay, redefining, discussion about the roles.

Eventually, partners structured a faster process by means of an informal assessment of the change requirements, which included a rough estimation of the solution and its cost to use as a criterion 
for starting (or not starting) the implementation of the formal procedure. This implied reformulating the formal process itself, identifying and correcting cumbersome procedures. Furthermore, the team agreed on contractual add-ons for reimbursing the time spent in drafting unsuccessful proposals and defining how to share the surplus. The private manager referred to this emerging agreement in the following terms:

The speed of the [functional] change process was quite low, and we had to reserve some time from the beginning until the end, we finally had an add-on in the contract. The main issue to evaluate was how to improve the speed of the process. But also, there was another part: The DBFMO contract does not provide everything in it, so there was an open end - for example, the costs we are making during the change are costs for our organization, but also profit of the work sum, the sum of the change, we do a general percentage over it. It was not agreed at the beginning of the contract. So, we also had to negotiate that during the years, and now it finished. That also made the procedure so long. Now it is overcome. And now, we can use that.

In the moment of collecting data, the extensive dialogue was no longer a usual practice. The public contract manager had learned how to frame the functional specification in a clear way to the private facility manager. Furthermore, the public contract manager would not question the price set by the private facility manager, and he even stated that he did not need to know how pricing was defined:

Now, after five years ... I give a blank check, do this for me. And call me when it is finished. At this moment when there is a change, I give you the function specifications, call me when it is ready and give me the bill. We don't need extensive dialogue, we know each other, we know it is right.... At the beginning we argued a lot about the prices ... now, when you say $100 €$, of course it is $100 €$ because you said $100 €$. I don't say when he says it is $100 €$ it should be $90 €$, no! But at the beginning you wonder why he said $100 €$, and not $99 € \ldots$ when it is cheaper the consortium gives me money back.

\subsubsection{Complementarity/Substitution from a Dynamic Perspective}

The evolution of the governing activity brings to light ambiguous characteristics of governing practices, acquiring different properties over time in relation to their relational and contractual basis. Using system dynamics notation, Figure 2.2 describes how the degree of contractual roles enactment and level of trust changed over time, during the process of adjusting the governance structure for introducing functional modifications during the operational phase of the project.

In the beginning, there was a low appropriation of contractual roles, low trust, and unawareness of the contractual adjustment required. The system changed as requirements of functional changes compelled managers to execute tasks by means of extensive dialogue, substituting the DBFMO roles allocation. Additionally, the implementation of tasks for introducing functional changes in the operation of the asset resulted in pitfalls, such as delays as a result of blurry responsibilities, discussion of prices, and claims on administrative costs not overseen by the formal procedure. These aspects reinforced the need to clarify roles, which on the one hand, reproduced the extensive dialogue 
practice, and on the other hand, triggered activities to adjust the procedure itself. The initial stage of the interaction constituted the rise of extensive dialogue as the main governing activity, substituting the enactment of contractual roles that clearly required that the public manager discuss the type of solution. But what can be defined as a substitution effect of this relational practice on contractual governance actually permitted the development of appropriate contractual roles and adjustments to the contractual procedure. The reduced emphasis on extensive dialogue over time was the result of day-to-day working dynamics, which allowed managers to emphasize the complementary aspect of their organizational functions and clarifying roles (extensive dialogue complementing contractual roles).

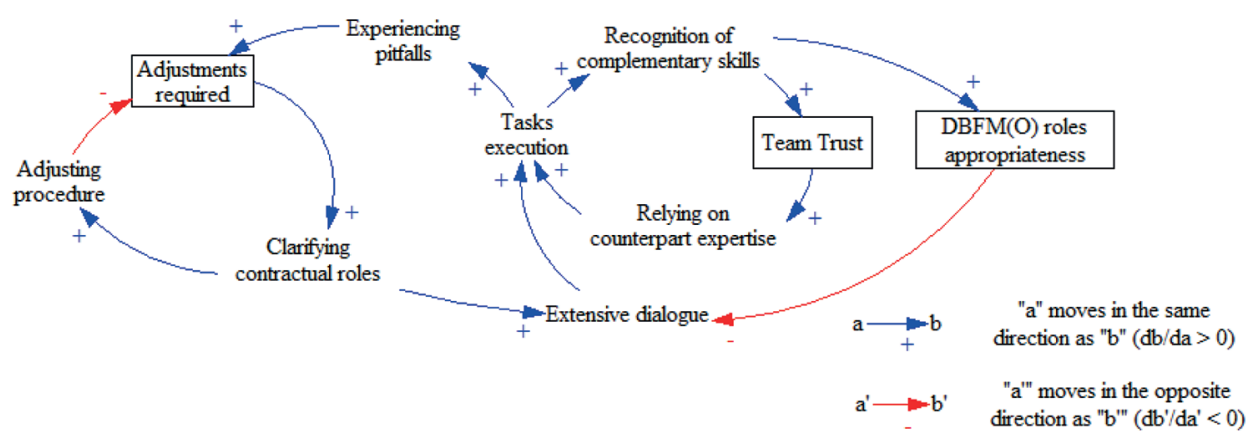

Figure 2.2 Introducing functional changes during the exploitation phase of a DBFMO contract

Performative complementarity turned out to be the basis for interpersonal trust between managers. Higher levels of interpersonal trust opened up the opportunity of relying on the counterpart's expertise, while higher levels of role appropriation reduced the need to use the extensive dialogue practice. Then, there was a transition period where the extensive dialogue and the reliance on the counterpart derived from the execution of the task, given the need to address procedure adjustments by clarifying roles (mutual complementation). The final shift from the extensive dialogue practice to reliance on the counterpart's expertise was the result of the reinforcing loop of trust driven by the complementarity of skills recognition, and the balancing loop of roles appropriateness. The dominance of trust at the end was possible as a result of the high levels of role appropriation between contractual managers, which made the extensive dialogue practice unnecessary (extensive dialogue substituting for trust).

\subsubsection{Cycles of Governing Activity and Underlying Managerial Struggle}

The rise and fall of the extensive dialogue describe a governing path where activity and interpersonal trust unfolded upon a change in the mode of interaction between managers, predisposed by the structural configuration of penalties, rewards, and beliefs. Interaction is triggered in T2 when the client experienced new building functionality, and managers had to negotiate the price and scope of the functional changes for its operation. The emergence of extensive dialogue as governing practice matches the situational logic of correction, which leads to concessionary modes of interaction. This means that there were material contradictions between the logic of operation of public and private organizations in $\mathrm{T1}$, compromising organizational stakes when introducing functional changes in the military facility. 
The DBFMO setting restricted the possibility of defining the specific characteristic of the asset, and introducing the life cycle cost implied a conflict on the public side of the partnership. The operation of the final user (ministry) required specific solutions reflecting the hierarchical values of the military (e.g., asking for specific furniture that symbolizes the hierarchical authority), while the contract manager was expected to follow the VfM principle (e.g., requiring working space for staff taking into account the life cycle cost). On the other hand, the lender evaluated the emerging risk from a given change, assessing the extent to which the private party would be able to make that service available in the future. Lenders are sensitive to the number of changes required, consistently increasing the risk premium over time and imposing pressure on the private contractor for acting cost-effectively. The special purpose vehicle was under pressure from the lenders, which would increase their risk profile in the case that introducing a functional change might imply extra penalties because of nonavailability.

Besides these vertical pressures that imposed demands on the managers, what is interesting is the creative capacity of the managers in changing their logic of interaction from concessionary to solidarity at the project level. In this regard, the emergence of extensive dialogue in T2-T3 had the background of isolating day-to-day activities from external pressures. These external pressures revealed the contradictions between organizational actors with different expectations and dissimilar perceptions of DBMFO fairness. In the words of the public contract manager:

In the back, there are more people. It is when you are playing football, there are people shouting, and they have their own opinion of the project. The consortium has the board, the people who spend money on it, invest the money, they want something in return. You have the users, high-rank military. On our side, we gave away a lot of things that we used to do for ourselves. Most of the people are very negative, sceptical about PPP. It is useless, it is spending money. There are a lot of negative feelings upon my shoulders, but also on the private manager's back.

Acknowledging their responsibility to comply with different vertical demands from their organizations, the managers were also aware of the need to build a strong team upon their professional complementarities with relative autonomy to the external pressures. The public contract manager explained:

So, who are my partners? Directly, only this team, as I said to the private manager and the user representative. We have to make a strong team, we have to arrange what we have to do, upon our expertise. What is my expertise, your expertise?

Therefore, setting boundaries and the recognition of mutual expertise emerging from the extensive dialogue were vital aspects to balance external negative pressure that might jeopardize the viability of the joint work of the project managers. According to the same manager:

With a strong team we can do the job of the project, and we have to fight - I mean, we don't have to fight, but we have to be strong with regard to the surroundings near us. 
The emergence of the extensive dialogue was the outcome of the managers'capacity to find innovative ways for complying with the double-vested interest related to their positions. This informal practice is actually consistent with "what contract managers are supposed to do," even when the specific activity cannot be predicted as a predefined behavioural script. While the vertical pressures seemed to remain during the interaction between managers in $\mathrm{T} 2-\mathrm{T} 3$, the agential powers to reshape constrictions at the project led to a change in the formal governance structure (T4). In the interaction (T2-T3), detailed examinations of the offers and costs during the extensive dialogues, along with the assessment of possible adjustments to the procedure, were driven by virtue of their reasonability (agential reflexivity). This means that managers were in the position to understand that contractual modifications implied the shifting of cost from one part to the other. Being reasonable, those shifts contributed to the reduction of mutual performative concerns and external pressure from parent organizations. The tipping point was the formal realignment of the system of penalties and rewards by means of re-elaborating formal processes, acknowledging administrative costs, and defining how to share the super plus of asset operation. Hence, T4 opens a new cycle of interaction upon the situational logic of protection, leading to a defensive rather than concessionary logic of interaction at the project level. Under this new logic, the managers not only identified themselves as a team, but they substituted the extensive dialogue by interactions based on trust (post-T4).

\subsection{DISCUSSION}

This article provides a fresh look at the multilevel conceptualization of project governance, in comparison to the economic understanding of managerial behaviour that is traditional in project management studies (Turner \& Müller, 2003). The traditional perspective imputes calculus, consistency, and selfishness as a static property of managers. As a result, the role of the manager as chief executive at a project level and as an agent of a hierarchical organization only leads to a higher risk of moral hazard and adverse selection (Turner \& Müller, 2003). The social realist approach questions rationality as an intrinsic property of managers, through differentiating the role of the manager as a position with a specific vested interest from the existence of the person who contingently fills that position. Organizational roles imply objective premiums to specific behaviours, but people filling those roles can creatively circumvent objective constraints. This assumption allows explanations of how the weakening of contractual principles may be a representation of a transition period leading to the strengthening of contractual governance. Furthermore, it allows for explanation of the emergence of different governing practices between managers who have to collaborate at the project level, but are also exposed to the interests of their parent organizations.

By defining contractual and relational activities as positioned-practices, the conceptualization of the interplay from a realist social perspective focuses on the change and reproduction of available governing activities that people can enact by virtue of their positions in the complex grid of positions and rules defining the structure of a PPP. It sheds light on how conflicting situations and solutions continuously emerge over time, by situating contracting and relational governing activity of people in "slotted" positions. Predispositions to engage in collaborative, concessionary, opportunistic, or competitive modes of interaction are a result of the structural relations between the profit-oriented 
logic of private organizations and the rule-bureaucratic logic of public organizations. This was illustrated in the case where the adjustment of formal procedures from a concessionary mode of interaction at the beginning of the operation phase eventually led to a more solidary interaction over time.

\subsubsection{Complexity of the Interplay Between Contractual and Relational Governance}

The process framework addresses the complexity of governing activities in PPP projects, using time for disentangling what appears to be paradoxical for the dichotomy lenses to assess the interplay between contractual and relational governance. For example, in the illustrative case, the extensive dialogue placed contractual roles between brackets in order to address the urgency to execute the project task in the short term, but at the same time to trigger a process of adjustment and role appropriation that led to trust and the final enactment of contractual functions. Therefore, the structure of penalties and rewards formalized in the contract does not necessarily require its enactment by pure contractual activity. Instead, it furnishes the possibility of a range of relational-type governing activities, defining the performative conditions where trust can emerge as part of the positioned-practice of managers. Hence, trust is not an act, but it is the psychological property of reflexive people filling the role of an actor in a specific situation. The psychological manifestation of trust emerges from, but cannot be reduced to, the structural predispositions and situational logics (e.g., solidarity, competition, compromise, opportunism). Trust can be developed in a situation where managers recognize themselves as actors being confronted with the contradictory system of penalties and rewards from their parent organizations, but having the vested interest in moving the project forward. Trust offsets the opportunity cost of deviating from the contractual script, under the expectation that collaboration would lead to more harmonious conditions for the next cycle of interaction.

While previous research has pointed out that time is the key aspect for providing sense to the apparent paradoxical nature of governance mechanisms (Howard et al., 2017), this article advocates understanding the hidden mechanisms underlying the stages of complementarity of substitution (Huber et al., 2013). It does so by distancing itself from the mainstream conceptualization of imputing inherent functionality to contractual and relational activity. Contractual and relational governance are neither complements nor substitutes of each other per se, but they emerge from the reflexive mediation of contradictory or complementary relations between systems of penalties, rewards, and beliefs attached to organizational positions arranged in a contingent or necessary fashion. Therefore, it is the situational logic that provides meaning to the type of interaction where the governing activity takes place, including its degree of functionality or dysfunctionality. Examining the situational logic of actors' governing practices can provide more clarity in those situations where "what is functional for one side of the dyad can be dysfunctional for the other party" (Howard et al., 2017, p. 14). From the realist perspective, this asymmetric valuation of functionality must have as an underlying driver some degree of contradiction between the system of penalties, rewards, and beliefs, or a contingent configuration of positions that increase the performative autonomy of project actors.

\subsubsection{Governing Activity and Governance Structure}

Another contribution of this article is the introduction of Archer's ontology as an alternative to structuration theory (Giddens, 1984) for guiding the empirical research on PPP governance activity and 
structure change. Both Archer and Giddens assert that social structures influence the social interaction among humans, and social structures are reproduced or changed by human activity. Nevertheless, Archer (1995) takes a different view from Giddens, rejecting mutual constitution. Archer's solution is based on emergence using time as the key to link agency and structure, because agency and structure are distinct from each other. Framing relational and contractual governance in the morphogenetic cycle clarifies the process whereby structural relations between diverse organizational rationalities in the past predispose specific contractual and relational activities in the present and shape the future of coming interactions. Rather than being a black box, the emergence of the complex repertory of relational and contractual governing actions is explained by structural dispositions, while actor interaction explicitly explains change and the reproduction of governance structure.

The distinction between emergence and mutual constitution is overlooked in project management studies but is crucial to understand how the perspective of governance as positioned-practices differs from governance-as-practice (Brunet, 2019). While the latter conceptualizes governing activity as the empirical enactment of institutional and organizational requirements (governance), the former emphasizes the mediating role of emerging situational logics and reflexivity between institutional and organizational requirements and the governing activity at the project level. Governance-as-practice not only neglects the differentiation between social governing and material governance, but also reduces the latter to artefacts (e.g., governance-written framework), the characteristics of which are "only relevant in relation to situated practices" (Brunet, 2019, p. 11). Therefore, the interplay between higher-level structure and activity enacted in the project is a black box that emphasizes the selfregulatory role of project actors but overlooks the preexisting systems of penalties, rewards, and beliefs that impute vested interests and predispose logics of interaction open to agential transformation over time. Governance is not only what people do (practices), but it also emerges from objective relations between positions (positioned-practices).

\subsubsection{Governance and Institutional Complexity in Ongoing Public-Private Partnerships}

This article defines the relationship between public and private organizations in PPPs as necessary at the project level, but contingent at the organizational level, as a second axis to fully understand the implications of complementarities and contradictions between different systems of penalties, rewards, and beliefs. In particular, it provides a consistent framework for examining how inventive individuals filling public and private managerial roles reshape contractual and informal relations when addressing conflicts. This is a substantive problem not adequately addressed by the PPP governance literature, which has recognized but not fully theorized the formal and informal aspects emerging from the relationship between organizations with different logics of operation.

The mediation of informal aspects between formal contracts and project performance in PPPs empirically identified by Benitez-Avila et al. (2018) is, from the perspective of realist social theory, a matter of necessity. Even the enforcement of a contract clause implies a reflexive process whereby "individuals make sense of governance and organizational design and act upon it" (Simard, Aubry, \& Laberge, 2018, p. 468). This insight was already recognized by the neo-institutional approach (Zenger et al., 2000). From the realist social perspective, with its introduction of situational logic, contracts also 
operate as one of the multiple structural demands imposed on project managers'agency. They create a necessary relationship defined as a partnership, predisposing concessionary or solidary modes of interaction between project managers, who are also exposed to opportunism and competence as a result of the contingent relations with their parent organizations. Not only do these predispositions encourage managers to enact/produce governing activities, but they also push them to modify or reproduce the governance structure itself. The emphasis on situational logic emerging from structural relations sets a crucial distinction between the social realist and the neo-institutional study of PPP governance.

From the neo-institutional perspective, the governance problem is the result of institutional complexity that generates conflicts between competing public and private institutional logics, added to the immaturity of a PPP as an institutional arrangement itself (Saz-Carranza \& Longo, 2012; South et al., 2018; Villani, Greco, \& Phillips, 2017). Actors rely on "existing institutionalized modes of interaction, regardless if they fit the situation or are compatible with other stakeholders from other perspectives" (South et al., 2018, p. 65). In consequence, governing activities should aim to increase the legitimacy of the PPP arrangement and its possibility to regulate different organizational stakes, attached to diverse institutional logics. PPP governance consists in recognizing, addressing, or embracing institutional complexity by means of involvement of and communication with stakeholders, learning spaces, encouraging capacity building, and acknowledging complementarities susceptible to exploitation in business models. By emphasizing the values shared among different entities, the neo-institutional perspective adopts a determinist conceptualization of project reality where actors operating under totalizing institutional logics come before their capacity to re-create relations (Donati, 2017). Realist social theory, on the other hand, suggests that situational logics emerge but are not reducible to the degrees of complementarity/contradiction between contingent or necessary organizational relations, embedded in the wider network of systemic and institutional relations. As a result, situational logic operates with a certain autonomy with respect to the values shared (or not) among entities, expressed in the predisposition for changing or maintaining the current systems of penalties, rewards, and beliefs mediated by human reflexivity. In analytical terms, the relation is the starting point and the "key way of getting to know the subjects and objects, and not the other way around" (Donati, 2017, p. 21).

\subsection{CONCLUSION}

This article introduced a process framework of PPP governance building on realist social theory and Archer (1995) morphogenetic cycle. It conceptualizes contractual and relational governance as activity paths resulting from the higher interplay between governing agency and project governance structure over time. The framework possesses the potential to explain governing features that appear to be paradoxical from the dichotomous perspective of governance interplay as the outcome of agential mediation of diverse structural demands. While the economic perspective of governance interplay reduces the relation between contractual and relational activity to the dichotomy of substitution/complementarity, the social realist perspective analyzes contradiction/complementarity in the contingent/necessary configuration of rewards, penalties, and beliefs that predispose diverse modes of interaction among partners. Final enactment and production of relational and contractual 
governing actions require reflexive actors, still free to find creative ways to comply with structural constraints and even accept the cost of diverging. Realist social theory calls for making a distinction between the activities, structural predispositions, and logics of actors' interaction, identifying the hidden mechanism that links these elements. Private and public organizations are social entities. Their economic interaction is materialized in the activity of managers conditioned by a dual role in their dayto-day working practice. The motivation behind a sociological conceptualization of economic activity is the need to confront decision-making models with the actual life of the projects, providing better frameworks for understanding change in inter-organizational temporal settings.

There are limitations to be addressed in future. First of all, the framework does not make explicit the implications for typical intertemporal governance problems in projects such as optimist biases (Flyvbjerg, 2013) and displaced agency (Henisz et al., 2012). At a policy level, it is necessary to theoretically clarify how the morphogenesis cycle at the project level interacts with cycles of policy change in modern societies, where the increasing involvement of the private sector in public affairs seems to be a normative characteristic of modern societies that promote "competition rather than concomitant complementarities" (Donati, 2015, p. 99). Finally, one central tenet of critical realist theory is the analytical differentiation between culture and material/political structure. In this framework, we have included them as the general definition of beliefs, while Archer (1995) warns that their relations in terms of autonomy and complementarity are independent.

Researchers are invited to provide more fine-grained insights on how structural relations predispose different types of trust or control activities, which empirically are observed as practices. They can explore the effect of implementing contractual mechanisms on the type of interaction between managers, expecting to discover particular paths of relational differentiation (Donati, 2017), emerging from bottom-up and top-down processes. The top-down perspective includes the investigation of emergence processes of specific PPP governance structures in interplay with the social and political struggles that take place at the policy level. On the other hand, the bottom-up approach calls for introducing a more detailed account of the micro-dynamics where contractual and relational activities take place, mediating diverse structural predispositions by day-to-day reflexive deliberations. In other words, the conceptualization of governance as positioned-practices opens up an opportunity to bridge the gap between project-as-practice literature focused on the deep empirical documentation of dayto-day managerial experiences (Blomquist et al., 2009) and the neo-institutional tradition that appeals to the existence of normative, regulatory, and cognitive scripts shaping behavioural expectations (Henisz et al., 2012). For example, researchers can further explore how day-to-day practices such as the horizontal process of operational consensus-seeking and the vertical process of strategic escalation (Hällgren \& Lindahl, 2017) are related to the institutional complexity of PPP in a specific policy context (Saz-Carranza \& Longo, 2012), by means of studying modes of interaction and situational logic.

This contribution is aligned with the recent call for questioning the core assumptions of the neoinstitutional theory, whose current maturity level in organizational science seems to have reached a midlife crisis (Alvesson \& Spicer, 2019). Rather than breeding expectations to find stable levels of legitimacy as the practical concern of neo-institutional scholarship, PPP can be studied assuming (and embracing) the everlasting struggle for changing or reproducing governance structures at the project, policy, and social levels. Given the illustrative nature of our case, scholars should also develop more 
solid research designs to investigate the dynamics of the managerial struggle embedded in multiple organizational levels. To address top-down and bottom-up research challenges, the framework presented here can be articulated with the guidelines for discovering institutional mechanisms in organizational case studies (Vincent \& Wapshott, 2014), where researchers are called to determine the configurational (structure of positions and activities), normative (gap between expectations and behavioural tendencies), and broader contextual conditions to which governing practices are related. In any case, the process framework does not claim predictive power, given that the social ontology that has been developed is based on the scientific premise that explanation is not predictive. Explaining is providing stories of emergence, accounting for the activation of causal mechanisms and why organizational forms and governing activities are so and not otherwise at a given moment in a specific organizational setting (Edwards, O'Mahoney, \& Vincent, 2014). 


\begin{tabular}{l} 
GOVERNANCE OF TEMPORARY \\
ORGANIZING IN THE CHANGING FIELD \\
OF PUBLIC-PRIVATE PARTNERSHIPS \\
\hline
\end{tabular}

\section{ABSTRACT}

The interface between temporary and permanent organizations remains fuzzy and intertwined, which makes the governance of temporary arrangements a challenging task. Previous research has mainly approached the dynamic nature of this interface from the perspective of agency and structure mutually constituted at different levels of organizing. We propose analytical dualism as an alternative perspective for understanding the governance of temporary organizing. Analytical dualism frames agency and structure as existentially dependent, but essentially different. It implies that temporary organizing emerges from, but cannot be reduced to the permanent as both levels operate at different strata of social organizing. By comparing three Public-Private Partnership projects as embedded cases in the Netherlands, we provide evidence that governing practices inside long-term temporary arrangements are embedded in field dynamics but do not necessarily co-evolve with these dynamics. Instead, they acquire relative autonomy once the governance structure is formalized in a time-bounded agreement. Agents are then able to shape the path of temporary organizing by the creative enactment of the initial conditions of the initial agreement.

Keywords: Temporary organizing - Governance - Public-Private Partnerships - Analytical Dualism 


\subsection{INTRODUCTION}

What is permanent and what is temporary appear to be fuzzy and intertwined in temporary interorganizational arrangements (Bakker et al., 2016). While planned isolation was considered as one of the characteristics defining the boundaries of temporary organizations (Lundin \& Söderholm, 1995), these boundaries have become more blurred due to an understanding of the temporary and the permanent as mutually constituted (Grabher, 2004; Sydow et al., 2004). Therefore, temporary and permanent coevolve over time at multiple levels of organizing. However, recent research reminds us that temporary forms of inter-organizational collaborations can outlast permanent structures (Brookes, Sage, Dainty, Locatelli, \&Whyte, 2017; South et al., 2018). These insights point to the existence of structural properties emerging from front-end governance agreements that resist or absorb exogenous disturbances and are activated by purposive actions during the execution of intended plans. We know that no temporary organization is an island given its contextual embeddedness (Engwall, 2003), but we also see that some of them are islands of stability in a turbulent sea by virtue of their temporary governance structures (Brookes et al., 2017). What is still less understood is the emergence, reproduction, and change of the structural governance mechanisms in temporary inter-organizational arrangements that safeguard or adapt intended plans to emerging and often conflictive demands from temporary and permanent organizing (Söderlund \& Borg, 2018; Söderlund \& Sydow, 2019; Sydow \& Braun, 2017). Or put differently, scholars have been largely silent about the extent to which initial governance structures of temporary organizations - that rely on doings once considered as legitimated at field level - remain stable or are re-shaped through governing activities within the temporary inter-organizational setting.

The prevailing lens for examining such a type of dynamics is Giddens' structuration theory (Giddens, 1984), which frames agency and structure as co-evolving due to their mutual constitution. Recently, structuration framework has been used for studying the dynamics of inter-organizational temporary organizing (Sydow \& Braun, 2017) and the relationship between projects, organizations and institutions (Söderlund \& Sydow, 2019). However, this framework conflates structure and agency and reduces structures to the instantiations at the will of the agents by insisting that structures are activity-dependent in the present tense (Cruickshank, 2003; Reed, 1997, 2001). Applied to temporary organizing studies, the mutual constitution view reinforces the fuzzy and intertwined view of the temporary-permanent interface. Therefore, it loses sight of the emerging structural properties of temporary arrangements stemming from contradictions or complementarities with the structural properties of the permanent organizations and fields. Analytical dualism (Archer, 1995) provides an alternative framework for studying the dynamics of temporary and permanent organizing. It argues that structure and agency are existentially interdependent but essentially distinct (Reed, 1997) and defines structures as internal and objective relations between slots of positions existing as results of agents entering into relationships (e.g. employer-employee; sealer-customer, patient-doctor, public partner-private partner) (Fleetwood, 2004). These structures are expressed in interests, resources, powers and constraints built into each position experienced in the present, but they are only activitydependent in a past tense (Bhaskar, 1998; Fleetwood, 2008; Reed, 2001). Therefore, ongoing activity and social interaction are predisposed by the structures shaped in the past, and agency can only modify structural properties for future interaction. This leads to what is known as the morphogenetic cycle (Archer, 1995) used in organizational studies for guiding empirical research in organizational change 
(Herepath, 2014; Tuominen \& Lehtonen, 2017) and for addressing the paradox of embedded agency and institutional complexity (Delbridge \& Edwards, 2013; Mutch, 2018).

We argue that governance structures of temporary inter-organizational arrangements are part of a sui generis micro-morphogenetic cycle, which emerges from, but is not reducible to the temporary agreement embodying the structural relations embodying the structural relations configuring the field level (Reed, 2001). In the sui generis morphogenetic cycle, objective slots of positions assumed by different actors are co-defined by the temporary and permanent (DeFillippi \& Sydow, 2016). For example, the temporary includes the necessary relations between public and private project managerial roles within an inter-organizational agreement according to what are considered legitimated forms of project governance. The permanent refers to the contingent relations between the same roles outside the agreement due to their membership in different parent organizations (Benitez-Avila, Hartmann, $\&$ Dewulf, 2019). Actors assume their dual role with vested interests to modify and/or reproduce their relations embodied in the initial agreement (Reed, 2001). These vested interests themselves can change over time due to the open nature of the temporary arrangement that is exposed to a wider network of (changing) relations at field level (Donati, 2017). This change is also the result of the actors' capacity to reflect on their relative positions, building new relations, and deploying inventive actions to deal with competing demands (Donati \& Archer, 2015).

The lenses of analytical dualism expand our understanding of temporary organizing by consistently linking embeddedness and the relative autonomy of temporary organizing dynamics. It makes explicit that temporal and permanent positions imposed on people operate at different layers of human organizing as interlinked but analytically separate (open) systems changing at different pace and directions. We elaborate on this argument through narratives of collaboration and contractual activity in the last phase of three Public-Private Partnership (PPP) projects in the Netherlands. Our results show that collaboration development along the three projects was strongly pre-disposed by the initial terms of each agreement and the contractual forms, reflecting the increasing emphasis on market-oriented relationing at field level. The permanent structured the governance of the temporary, which in turn embodied the historical configuration of autonomy and control relationing at the PPP field level. However, the particular dynamics of collaboration and conflict at the project level remained dependent on the cycles of reproduction and change within each public-private agreement. In fact, the internal relationing at project levels was reproduced regardless of the change in PPP policy and values at field level. These results bring to light the embeddedness but also the relative autonomy of temporary organizing once its governance structure is formalized in a time-bounded agreement. Accordingly, we discuss the temporary-permanent interface along three theoretical contributions. First, temporary and permanent organizing operates at different strata of social organizing. Second, governing practices are necessarily articulated to positions, vested interests and relations in governance configurations. Third, morphogenetic times exist beyond objective and subjective times in temporary organizing. 


\subsection{AGENCY, STRUCTURE AND GOVERNANCE OF TEMPORARY ORGANIZING}

\subsubsection{The Structuration Perspective and the Idea of Mutual Constitution}

The theory of temporary organization originally introduced planned isolation as the stage where teams address disturbances jeopardizing the initial temporary agreement. (Lundin \& Söderholm, 1995). However, further research only maintained institutional termination as a constituting element of the temporary organizing concept, while it disregarded the analytical value of its preceding isolating process (Bakker et al., 2016). The idea of planned isolation reified the engineering approach of project governance towards optimization, the pitfall of which was to assume that front-end temporary structures remain decoupled from its contextual environment when properly arranged (Blomquist \& Packendorff, 1998; Grabher, 2002). It was particularly insightful to observe that engineering projects designed according to guidelines for success turned into a failure, in comparison to those successful ones relying on less structured but more socially acceptable ways of project organizing (Engwall, 2003). This success/failure paradox was only satisfactorily explained by framing temporary activity embedded in a historical organizational context (Grabher, 2002). Structuration theory (Giddens, 1984) provided a perspective to make this embeddedness more explicit as to how temporary organizing coevolves with its permanent contexts (Windeler \& Sydow, 2001). In the co-evolutionary process, actors at project level need to refer in their temporary micro-practice to the specific rules of signification and legitimization that, for the time being, constitute the legitimate and shared doings at the more permanent macro-level. And yet, by the same token, the enactment of shared practices to coordinate temporary activities affect the prevailing set of rules of signification and legitimization and therefore the ideal doings at the more permanent level.

Using Giddens idea of mutual constitution as sensitizing conceptualization (Sydow \& Staber, 2002), temporary organizing scholarship equated temporary to agency, permanent to structure and their mutual constitution to practices. In fact, structuration theory assumes that structures are nothing more than instantiation at the will of the agents (Reed, 1997, 2001). Some refer to "Giddens' ontology of practices" (Cruickshank, 2003, p. 69) for bringing to light this implicit ontological commitment of structuration theory. Accordingly, the literature studied how practices of temporary organizing bring into play (and re-shape) permanent contexts such as networks (Sydow \& Staber, 2002), parent organizations (Sydow et al., 2004), and institutions (Sydow \& Braun, 2017; Tukiainen \& Granqvist, 2016). Reflexive and strategically positioned actors drive the co-evolution of the temporary and permanent over time (Manning, 2008; Sydow et al., 2004; Windeler \& Sydow, 2001), dealing with the shadows of past and future (Stjerne \& Svejenova, 2016; Tukiainen \& Granqvist, 2016) and disembodying and re-embedding permanent structures of signification and legitimization in their temporary practices (Bresnen, Goussevskaia, \& Swan, 2004; Sydow et al., 2004).

The underlying ontology of practices in structuration theory leads to a legacy of voluntarism in the governance of temporary organizing. For example, networks operate as latent organizations with structural properties such as diversity of potential relations (Staber \& Sydow, 2002; Starkey, Barnatt, \& Tempest, 2000). Its temporary activation depends on actor interpretations of previous interactions 
and expectations of future encounters (Grabher, 2002; Laura Poppo, Zhou, \& Ryu, 2008). Temporary boundary-spanning practices such as framing the future encourage actors to collaborate in the present or synchronize current practices by referring to past experiences (Ligthart, Oerlemans, \& Noorderhaven, 2016; Stjerne, Söderlund, \& Minbaeva, 2018). Additionally, actors make use of boundary work for drawing and redrawing temporary and permanent boundaries (Stjerne \& Svejenova, 2016). Actors couple or decouple projects from their permanent organizations to deal with "attachmentdetachment" dilemmas (Sydow et al., 2004). The need for autonomy at the project level conflicts with the demand for integrating project activities within parent organization routines. In interorganizational projects, "well-known contract(s) and common work procedures" (Swärd, 2016, p. 1856) are conceptualized as reciprocal norms provided by fields. Actors within the (short-term) temporary organization eventually develop their idiosyncratic reciprocal behaviour at the project level, which nevertheless shifts again to the industrial norms at the end of the agreement (Swärd, 2016). This ability to couple and decouple the temporary to the permanent takes for granted that legitimate ways of doing in permanent contexts marginally and incrementally change along the practice of (short) temporary organizing (Brookes et al., 2017). Overall, the explanatory power of structures in general - and temporary governance structures in particular - disappeared from the analysis of temporary organizing. As actors have the capacity to manipulate the meaning of temporary and permanent by their doings, clarifying the "intricate concoction" (Grabher, 2004, p. 1509) of project, organization, network and field structures seems irrelevant for the analysis.

However, the relevance of structural properties of temporary agreements is reflected in recent interests in the inter-organizational governance of temporary organizing (Sydow \& Braun, 2017). Temporary inter-organizational cooperation can be jeopardized through the co-definition of actor roles. Actors have positions in the hierarchy of permanent organizations that can be in tension with the scripts of behaviour defined by time-bounded agreements (DeFillippi \& Sydow, 2016). Furthermore, organizational and field contexts can radically change during the execution of long-term temporary agreements. These agreements usually outlast the participation of their organizational members, and they are designed to endure the changing circumstances at organizational and field levels (Brookes et al., 2017; Van Marrewijk, 2017). The process of value co-creation in long-term agreements relies on the integrity of the front-end governance design aimed at maintaining the commitment of different permanent organizations (Rhodes, 2007; Sydow \& Braun, 2017). Plus, the long-term nature of some agreements implies that legitimated ways of doings at temporary and permanent levels have a different tempo and dynamics (Bakker et al., 2016; Söderlund \& Borg, 2018). People live with diverse identities and competing values due to their positions shaped by temporary agreements, permanent organizations, and fields operating with diverse dynamics (Söderlund \& Borg, 2018; Söderlund \& Sydow, 2019). Positions in the field and organizational levels constrain the purposive introduction of new temporary organizing practices and building new relations by organizations that pursue change (Lieftink, Smits, \& Lauche, 2019). However, Giddens' ontology of practices places agency-structure interaction in a black box (Archer, 1995), as their legacy does with the interface between temporary and permanent and its role for the governance of temporary organizing (Bakker et al., 2016). 


\subsubsection{The Perspective of Analytical Dualism and the Morphogenetic Approach}

Analytical dualism frames structures and human agency as different levels of social reality, whose point of contact are the so-called positioned-practices (Bhaskar, 1998). These are activities that individuals can engage in by virtue of their position (e.g., places, functions, rules, tasks). The process of change and reproduction of positioned-practices evolves in morphogenetic and morphostasis cycles (Archer, 1995). Morphogenesis refers to change, while morphostasis refers to the reproduction of open systems ${ }^{15}$. In these cycles, pre-existing structures and cultural systems in the past (T1) predispose (but do not determine) agents to engage patterns of interaction in the present (T2-T3) for transforming and reproducing structural relations and beliefs operating as an objective basis for future interactions (T4) (Archer, 1995). Predisposition for solidary, concessionary, competitive, or opportunistic modes of interaction in (T2-T3) emerges from the relation between structural positions and cultural systems. The nature of a structural relation is defined by its degree of necessity (or contingency) and complementarity (or contradiction), shaping positions and cultural systems in T1. People can reflect, prioritize, and find creative ways to enact competing structural demands attached to their positions, circumventing constraints, and eventually come up with new forms of relationing to transform the context of their activity over time (Archer, 2007; Caetano, 2015). Congruity or incongruity of the interaction of groups defining identities and pushing for their vested interest in relation to hegemonic ideas (culture) and positions (structure) in (T2-T3) is what explains the change of the social systems, re-organization or existing groups and emergence of new ones in T4 (Archer, 1995).

Organizational scholars have used the broad categories developed by Archer (1995) to bring to light the relevance of structural predispositions and vested interest assumed by people filling positions (Delbridge \& Edwards, 2013; Herepath, 2014; Reed, 2001; Tuominen \& Lehtonen, 2017). The critical realist tradition frames organizing levels (e.g. project, organization, field) as a layered network of relations between positioned practices existentially interdependent but essentially distinct (Reed, 1997). In the stratified realist ontology, each level operates at different strata susceptible to be analyzed in morphogenetic cycles (Herepath, 2014) ${ }^{16}$. Additionally, layered strata are related by upwards and downwards causation (Vincent \& Wapshott, 2014). In upwards causation, the properties of a higher organizing level emerge as the effect of relations at a lower level: for example, the effect of project teams' activity on the productive powers of an organization. In downwards configuration, the properties at lower level emerge as an effect of relations at a higher level. This is the case when engaging a specific contractual relationship in a project due to the ruling policy at field level. This latticework of layered relations of positioned-practices often places inconsistent and incoherent demands on individuals filling organizational positions (Reed, 2001). Individuals can regroup as agents sharing some vested interest for specific matters by virtue of their roles as actors, but they can be in different positions in other respects as they face diverse demands (Tuominen \& Lehtonen, 2017).

\footnotetext{
${ }^{15}$ By definition, the morphogenetic approach is a systemic perspective (Archer, 1995). Therefore, the layout of social reality is given by a set of relations between components that defines forms, structure and state. However, for the critical realist, social systems are open by nature. This means that the observed phenomena emerging from the system is subject to constellation of causal mechanisms exposed to contingency and human creativity (Steinmetz, 2004). Social systems are not predictable, but explainable by tracking back the process of change and reproduction.

${ }^{16}$ Henceforth, when we refer to "morphogenetic cycle" as a process framework for analyzing organizing phenomena, we also mean the idea of reproduction emerging from morphostatic cycles.
} 
The morphogenetic approach based on analytical dualism offers a process framework for capturing the governance of temporary organizing as an open system, emerging from, but not being reduced to the dynamics of organizations interacting at field level. This perspective is able to address governance choices and paradoxical tensions experienced by project managers in long-term projects (Benitez-Avila, Hartmann, \& Dewulf, 2019). Practices such as enacting contractual arrangements are then positioned practices emerging from the dual role of project managers at the project and organizational level. The project is a temporary but necessary relationship that predisposes project managers to engage in solidary or concessional ways of interactions. The permanent is the contingent relation between parent organizations predisposing the same project managers to competition and opportunism. Fleetwood (2008) uses the case of the labour market to clarify the necessary nature of working relations emerging from contractual agreements. Before a contractual engagement, the working power of an individual is independent of the hiring power of an employer. A necessary relation emerges from signing contracts between entities who were unrelated before as their powers existed independently of any relation between them. The relation is necessary as it is internal: the nature of one relata (e.g. employee) depends on the nature of the other (e.g. employer) (Fleetwood, 2008) ${ }^{17}$. Both parties acquire new powers from entering into this internal relation, along with the specific demands the relationship entails. In inter-organizational projects, project managers have an internal relationship with their counterpart at the project level and another internal relation with their parent organization (Benitez-Avila et al., 2019). Yet, these two necessary relations can impose competing demands on the same person. Therefore, people filling project managerial roles usually need to prioritize or conceal multiple demands due to this dual position.

Furthermore, demands at the project level are not abstracted from the structural relations operating in the permanent contexts. If it is true that contracting generates a necessary but temporary relationship, the once unrelated entities acquire their powers by virtue of their position in deeper structures such as labour markets or organizational fields (Fleetwood, 2008). Field refers to the latticework of control and autonomy relations between collective actors entering in organizational situations, including forms of organized activity, technologies and practices (Fleetwood, 2008; Reed, 2001). Control and autonomy relations between collective actors in a specific field are built upon the configuration of generalized beliefs of reciprocity and objective compliance systems to perform an activity in an organizational situation (Reed, 2001). Organized groups can recognize themselves with a vested interest to maintain or improve their expert position in governing organizational situations, challenging or defending the beliefs and resources maintaining the structures of control and autonomy in the field. Governance codes for temporary organizing emerge from organized groups mobilizing material and symbolic resources to reproduce or modify the internal relations of the permanent context. Governance structures emerging from temporary agreements such as PPP contracts embody the particular definition of roles and priorities, articulated in a historical configuration of public-private relationing (Benitez-Avila et al., 2019; Reed, 2001). Relationing refers to the internal relations at the field level, defining positions of expertise, control and autonomy between groups in organizational situations.

\footnotetext{
${ }_{17}$ Here, (Fleetwood, 2008) presents the idea of internal relations following the canonical definition of a necessary relation drawn (Archer, 1995). Necessity "only states that X cannot be what it is without certain constituents A, B, C, N' and the relations between them" (Archer, 1995, p. 174)
} 
Demands from multiple levels of human organizing do not operate consistently, nor as mechanical pressures. Instead, structural predispositions are manifested in associative and dissociative relations that are enacted and recreated by human action in T2-T3 (Donati \& Archer, 2015). The dynamics of a relationship in T2-T3 is an effect of reciprocity emerging from its intertwining subjective and objective components. The objective side of a relation comprises the bounds defined by structures manifested as instrumental-normative connections. The subjective side of a relation is the symbolic reference stemming from motivations and meanings. There is an emergent reciprocal effect irreducible to objective bounds or subjective symbolic references operating as a surplus (Donati \& Archer, 2015). This surplus is manifested either as third strata of reality in (T2-T3) experienced in terms of relational good (e.g. pleasant working environment) or relational evils (e.g. tense working environment). Individuals can reflect on the influence of their objective bounds with relevant others on themselves and vice versa, along with the relational goods and evils emerging from the subjective enactment of objective bounds (Donati, 2015, 2016, 2017). Conflict, opportunity and creativity in the subjective enactment of objective demands open the space for recreating relations and introducing change (Donati, 2011). Within projects, governing activity is the outcome of managers reflecting, prioritizing and concealing horizontal and vertical demands in (T2-T3). The interaction leads to the change or reproduction of the temporary agreement structure and parent organization level in (T4) (Benitez-Avila et al., 2019).

As relationing embodied in temporary governance structures is the blueprint of temporary organizing activity in (T2-T3), Donati (2013) provides elements to clarify that actors might introduce change in the configuration of working activities without altering relationing. He specifies the degree of transformation of the objective bonds in social systems along with four possible directions from T1 to T4 (Donati, 2013). It includes Morphostasis, Developmental Morphogenesis, Purely Interactional Morphogenesis and Creative Morphogenesis. Morphostasis $(X \rightarrow Y S)$ is the process in which the constitutive parts of the structure are reproduced, leading to an identical whole. Therefore, the stability of the system is provided by the self-reproduction of the elements (reinforcing loop) as the main mechanical feedback defining the path of interaction over time. Developmental Morphogenesis $(X \rightarrow$ YD) refers to the evolutive process in which parts change in accordance with the blueprint of the system structure. The stability of the system is provided by mechanisms that reinforce the blueprint of the structure by altering elements to increase their adaptation capacity. Purely Interactional Morphogenesis ( $X \rightarrow$ YI) introduces contingency and change undermining the existing blueprint, without defining a new stable relationing. The structured whole leads to an unorganized heap or arena of chaotic interactions. In (4) Creative Morphogenesis $(X \rightarrow Y G)$, parts change defining new relationships as the emergent outcome of people's capacity to reflect and alter ongoing positions and relations. In other words, there is a new relationing. The new structure $Y$ presents properties different from $X$, with stable new powers differing by virtue of relational and mechanical feedbacks ${ }^{18}$.

In summary, the morphogenetic cycle altering or reproducing temporary governance structures defines the temporary and permanent interface. Once the temporary agreement is formalized in a time-bounded governance structure, actors acquire powers and liabilities due to the internal

\footnotetext{
${ }^{18}$ Mechanical feedbacks, including positive feedbacks (+), lead to growth and amplification of variations or reproductions of the initial structure, and negative feedbacks (-) lead to equilibria by counterbalancing variations. Relational feedbacks treat variations always as "open and negotiable in a network having relationally in common between agents/actors, but not necessarily the same values, habits and interventions styles" (Donati, 2013, p. 225).
} 
relations defining relative positions in relation to each other. These positions define the practices that actors can and cannot perform (positioned practices), considering their dual role at the temporary and permanent systems. In other words, practices are subrogated to the embodied configuration of control and autonomy relations formalized in the time-bounded governance structure. Now, the embedded configuration of autonomy and control shape vested interest in terms of predispositions for contesting or protecting the embodied relationality of the time-bounded governance structure. Additionally, people assuming roles in temporary and permanent organizing can share vested interests for specific matters but have competitive vested interests in other levels. The congruity and incongruity of individuals and groups facing demands and pushing for vested interests introduce dynamics to the internal relations of projects, organizations and fields. Furthermore, people can creatively enact and re-create the structural relationing embodied in temporary organizing. Vested interest emerging from the time-bounded agreement and people creativity concealing competing demands account for the embeddedness but also the relative autonomy of temporary organizing, once its governance structure is formalized in a time-bounded agreement. Upon these bases, we argue that the sui generis morphogenetic cycle at the project level is existentially interdependent but analytically distinct from the dynamics of more permanent organizations and fields. In comparison to the structuration theory and its underlying ontology of practices, the layered and emerging standpoint of analytical dualism might better capture the dynamics of change and reproduction of internal relations of different organizing levels with different tempos and direction of change.

\subsection{RESEARCH CONTEXT}

To study the emergence, reproduction and change of temporary governance structures in relation to the dynamics of more permanent organizations and fields, we compared the path of three PublicPrivate Partnerships (PPPs) as embedded cases in the Netherlands. PPPs are "long-term contracts between a private party and a government entity, for providing a public asset or service, in which the private party bears significant risk and management responsibility, and remuneration is linked to performance' (World-Bank, 2014, p. 18). In concessional PPPs, the commissioner transfers to the market the entire life cycle of a public infrastructure project, including the up-front financing (Hodge et al., 2018). This model is known in the Netherlands as a Design-Building-Finance-Maintain (DBFM) contract, tendered according to European directives (Edelenbos \& Klijn, 2009). DBFM contracts establish the legal relationship between a public infrastructure commissioner and a private Special Purpose Vehicle (SPV). The public commissioner in the Netherlands is the Highways Agency - HA (Rijkswaterstaat in Dutch). The HA is organized in a Central Office and Regional Districts. At the central office, the GPO unit (Groot Projecten en Onderhoud) is in charge of infrastructure realization, and the PPO (Programma's Projecten en Onderhoud) is in charge of asset management. There is also a special unit of procurement defining the tendering procedures and safeguarding the integrity of contractual commitments from a legal point of view (Inkoopcentrum Grond- Weg- en Waterbouw - ICG). The internal users are the regional districts. The SPV on the private side establishes back-to-back contracts with two main subcontractors: the EPC (Engineering-Procurement-Construction) and the MTC (Maintenance Company) contractor. Due to the agreement between the lender and the SPV, eventual over-cost/penalties are transferred from the SPV to the EPC or MTC through these back-to-back contracts. 
From a historical perspective, DBFM contracting in the Netherlands emerged from the erosion of the corporatist tradition based on pre-consultation. Pre-consultation was a collusion practice formally included in Dutch law in 1953 (Graafland \& van Liedekerke, 2011). This practice aimed to "prevent commissioners approaching individual contractors separately until one offered to take up the contract [as well as to offset] the expenses incurred in preparing a bid" (Sminia, 2011, p. 1560). Colluding practices were legitimized by the high value attributed to cooperation, consensus-seeking and compromising for smoothing struggle and rivalry (Bremer \& Kok, 2000; Winch, 2010). Nevertheless, in 1992, the European Commission imposed a fine on Dutch companies for restricting competition, leading to "outrage" in the Dutch industry and government alike. The once legitimated practice turned into a fraud case in 2002 as actors kept practising pre-consultation and price-fixing regardless of its illegalization by the national law in 1998 (Dorée, 2004; Sminia, 2011). The power-induced irruption via parliamentary committee inquiry definitely shifted the centre of control/trust relationships of the construction activity from the corporatist network, thereby reducing planning uncertainty by fixing prices to the contracting relationing legitimized by the ideological principle that competition is good (Dorée, 2004). Furthermore, the committee explicitly recommended the Anglo-Saxon PublicPrivate Partnership model to encourage cooperation with transparency (Graafland \& van Liedekerke, 2011). The embodied relationing in Anglo-Saxon PPPs implies the alignment of incentives between commissioner and contractor, based on the discrete allocation of responsibilities and risk at the frontend of the project. The discrete allocation of responsibilities strongly contrasted with the tradition of negotiated public-private coordination in the Netherlands.

Whereas there was an initial wave of PPP implementation back to the 1980s and early 90s in alliance contract forms, DBFM arrangements were introduced in a second wave under the principle of "more value through collaboration" in 1998. This wave emphasized that the soft aspects of cooperation were aligned with the Dutch corporatist tradition. Between 2004 and 2011, the development of DBFM contracts took off in the third wave of adaptation under the policy "Market, unless" and after the collusion scandal (Matos-Castaño et al., 2014). The fourth wave of PPP development is witnessed from 2011 onwards boosted by governmental coalition pursuing as many DBFM contracts as possible in response to the financial crisis (Koppenjan \& de Jong, 2018). Since 2016 the policy discourse has shifted away from the new public management accent in DBFM relationing to a more general approach of value creation through close cooperation and trust-building. According to Koppenjan and de Jong (2018, p. 180), the Ministry of Finance and Audit office kept fiercely promoting the initial transplant while "practitioners [tried] to bend the rigid contract conditions to cope with emerging tensions" (Koppenjan \& de Jong, 2018, p. 180). The Ministry of Infrastructure and Waterworks articulated the voice of practitioners in the policy discussion. The market vision released in 2016 and endorsed by Dutch authorities acknowledged "the misfit between orthodox Anglo-Saxon practices and the need to pay attention to the quality of collaboration and relationships" (Koppenjan \& de Jong, 2018, p. 181). 


\subsection{RESEARCH DESIGN}

\subsubsection{Case Studies}

The selection of the investigated projects was based on expectations to find relevant data for addressing the research concern (Flyvbjerg, 2006), following the realist principle of light theorization by selectingfor-difference (Kessler \& Bach, 2014) ${ }^{19}$. Light theorization is a "tentative but a plausible account of similarities or differences that might be revealed by the case comparison [...] which centres on how structure and agency interact at different levels to produce these similarities or differences" (Kessler \& Bach, 2014, p. 173). If the researcher establishes divergence in process and outcomes after selectingfor-difference, there is an indication that structural and institutional features prevailed over the agency. On the contrary, convergence in the process and outcomes between cases selected-by-difference might indicate a wider scope of agency. We selected three PPP projects for difference, belonging to different waves of PPP adoption in the Netherlands (Koppenjan \& de Jong, 2018; Matos-Castaño et al., 2014). The N31 project was procured during the Dutch policy of "more value through collaboration", which emphasized soft aspects of cooperation aligned with corporatist Dutch tradition. The II Coen Tunnel was procured under the policy "Market, unless..." reflecting the policy turn to liberalization in the context of new European Procurement Guidelines, and increasing public budgetary restrictions for addressing the infrastructure gap (Bult-Spiering \& Dewulf, 2006). The N33 project was procured during the period of a full endorsement of $\mathrm{VFM}$ principles when a governmental coalition aimed to pursue as many as DBFM projects due to the financial crisis. The data collection and retrospective analysis were carried out during the post-crisis period, when the policy discourse shifted back to the relevance of close public-private cooperation. According to our light theorization, we expected that the historical procurement moment accounted for the path of change and reproduction of the project governance structures and governing practices.

In order to retrospectively account for the path of interaction in the projects, we identified contractual documents that deal with key project events or formalize emerging agreements/adjustments during the maintenance phase. These events constituted our point of departure for carrying out interviews to contract and project managers. They were asked for their role during these events, other roles, the type of interaction they re-called, and the extent to which these events are still relevant for understanding the type of interaction they currently maintain with the counterpart. During the conversations, the interviewer aimed at exploring non-documented events that might relate to the existing type of relationship, process and outcomes of the project. Additional interviews were conducted with the public organizational clients of the projects and the technical lender's advisor in one case. In total, we interviewed 16 people in 18 interview sessions (average time: 1 hour and 30 minutes). Documentation of the project structure, as well as online policy documents and reports, were used to triangulate facts for the description of the cases. It allowed us to reach a better understanding of the type of relationing between organizations in a DBFM situation in the Netherlands (Table 3.1).

\footnotetext{
${ }^{19}$ Kessler and Bach (2014)explicitly re-framed "light theorization"from a morphogenetic approach to compare cases in organizational studies.
} 
Table 3.1 Cases and data

\begin{tabular}{|c|c|c|c|}
\hline & N31 & II Coen Tunnel & N33 \\
\hline Short description & $\begin{array}{l}\text { Highway between } \\
\text { Leeuwarden and Nijega } \\
(23 \mathrm{Km})\end{array}$ & $\begin{array}{l}\text { Maintenance of an existing } \\
\text { tunnel under the North } \\
\text { Sea in western Amsterdam, } \\
\text { and construction of a } \\
\text { second one. }\end{array}$ & $\begin{array}{l}\text { Highway between Assen } \\
\text { and Zuidbroek (38 Km) }\end{array}$ \\
\hline Invitation to tender & $1-3-2002$ & $22-7-2005$ & $28-4-2011$ \\
\hline Prefer bidder announcement & $8-12-2003$ & $22-4-2008$ & $1-10-2012$ \\
\hline Financial close & $10-12-2003$ & $10-6-2008$ & $21-11-2012$ \\
\hline Commencement certificate & $1-4-2004$ & $1-5-2008$ & $25-2-2013$ \\
\hline $\begin{array}{l}\text { Completion certificate } \\
\text { (planned) }\end{array}$ & $31-3-2008$ & $21-3-2014$ & $30-12-2014$ \\
\hline $\begin{array}{l}\text { Completion certificate } \\
\text { (actual) }\end{array}$ & $13-12-2007$ & $21-3-2014$ & 8-12-2014 \\
\hline Planned transfer certificate & $31-12-2022$ & $31-12-2037$ & $30-9-2034$ \\
\hline $\begin{array}{l}\text { Formal contractual } \\
\text { documentation }\end{array}$ & $\begin{array}{l}14 \text { contractual } \\
\text { documentation } \\
2005-2017\end{array}$ & $\begin{array}{l}14 \text { contractual } \\
\text { documentation } \\
2010-2017\end{array}$ & $\begin{array}{l}2 \text { contractual } \\
\text { documentation } \\
\text { (2015) }\end{array}$ \\
\hline Interviews 2016-2019 & $\begin{array}{l}\text { - Public Contract Manager } \\
\text { (Two rounds) } \\
\text { - Public Project Manager } \\
\text { (Two rounds) } \\
\text { - Private Asset Manager } \\
\text { - Private Project Manager } \\
\text { - Public head of the district } \\
\text { (Internal user) }\end{array}$ & $\begin{array}{l}\text { - Public Contract Manager } \\
\text { (Three rounds) } \\
\text { - Public Project Manager } \\
\text { - Private Contract Manager } \\
\text { - Private lender advisor } \\
\text { - Public Asset Manager } \\
\text { (Internal user) } \\
\text { - Public Tunnel Manager } \\
\text { (internal user) }\end{array}$ & $\begin{array}{l}\text { - Public Contract Manager } \\
\text { (Two rounds) }^{\mathrm{a}} \\
\text { - Public Project Manager } \\
\text { (Two rounds) }^{\mathrm{b}} \\
\text { - Private Asset Manager } \\
\text { - Private Contract } \\
\text { Manager } \\
\text { - Public head of the } \\
\text { district (Internal user) }\end{array}$ \\
\hline & \multicolumn{3}{|c|}{$\begin{array}{l}\text { - Public Senior Juridical advisor Id } \\
\text { - Public Senior Juridical advisor } \|^{d}\end{array}$} \\
\hline
\end{tabular}

a Public Contract Manager for the N31 and N33 is the same person; ${ }^{b}$ Public Project manager for the N31 and N33 is the same person; ${ }^{c}$ Interviewed at the same time; ${ }^{d}$ Interviewed at the same time

\subsubsection{Analytical tactics}

\subsubsection{AGIL Categories}

Case studies using narratives have been regarded as a powerful approach to account for process studies (Burke \& Morley, 2016; Langley, Smallman, Tsoukas, \& Van de Ven, 2013). Even more important, narratives are the canonical type of explanation in critical realism (Porpora, 2001). Archer herself explains that the application of the morphogenetic approach produces analytical narratives that account for the emergence and reproduction of social systems (Archer, 1995). Following the morphogenetic framework, Donati (2013) adapts AGIL categories for describing the initial configuration of structural relations and the process of change and reproduction by their subjective enactment by people. AGIL stands for A-means (or adaptation criteria), G-goals, I-norms (or integration), L-values (or latency) as orientations of meaning of social facts (e.g. action, exchange, relation, structure, system, network) by 
the agents/actors who generate or maintain these social facts as meaningful wholes over time (Donati, 2017). In general, AGIL "works like a hypothesis against which empirical reality is analyzed by using the same logic of the scientific investigations where empirical frequencies are compared to the expected ones in order to see how the black box works" (Donati, 2017, p. 51). In order to structure a narrative of change, Donati (2017) coined the concept of relational differentiation. Relational differentiation is the emergent effect of actors enacting, reproducing or transforming AGIL over time. Therefore, a path of relational differentiation describes how relationing in terms of AGIL at T1 moves to T2 along four directions of change (morphostasis, adaptive morphogenesis, interaction morphogenesis and creative morphogenesis).

We departed from the fact that concessional PPP contracts are governance designs, with default characteristics well defined in the literature (Hodge et al., 2018). AGIL describes the default elements of concessional PPP in the following terms. The adaptation criteria or objective means (A from AGIL) for concessional PPPs introduces efficiency by bundling the provision of long-term asset performance through a private Special Purpose Vehicle (SPV). The goal or subjective criteria of legitimacy (G from AGIL) is efficacy in terms of public objectives and levels of service defined by the public procurement organization. The Normative Integration (I from AGIL) or objective normative bounds is the contractual organization of the transaction establishing availability fees and penalties for non-compliance. The discipline imposed by the contractual agreement between the SPV and the lender reinforces the system of penalties and rewards of the DBFM contract. The criteria of Latency is the value of the relationship itself ( $L$ from $A G I L)$, defined as collaboration in terms of negotiating who is the best actor to deal with project risks. Table 3.2 presents the second-order AGIL relations characterizing the default relationing in concessional PPPs according to the literature (Hodge et al., 2018). Our empirical task was to define the second-order AGIL relation reproduced or changed by activity, as well as the number of cycles, whereby those components change or reproduce in the three projects. As a rule of thumb, we defined the number of paths per project by the number of AGIL components changed/reproduced, without analytically altering other AGIL components.

Table 3.2 Second-order AGIL relations characterizing the default relationing in concessional PPPS

\begin{tabular}{|c|c|c|c|}
\hline & (A) Efficiency & (G) Efficacy & (I) Normative \\
\hline (G) Efficacy & $\begin{array}{l}(\mathrm{G} \leftrightarrow \mathrm{A}) \\
\text { Long term value for money } \\
(\mathrm{VfM})\end{array}$ & & \\
\hline (I) Normative & $\begin{array}{l}(\mathrm{I} \leftrightarrow \mathrm{A}) \\
\text { Banks assess emergent risks } \\
\text { from life-cycle cost. }\end{array}$ & $\begin{array}{l}(\mathrm{G} \leftrightarrow \mathrm{I}) \\
\text { Government activates penalties } \\
\text { given service/availability; }\end{array}$ & \\
\hline $\begin{array}{l}(\mathrm{L}) \text { The intrinsic } \\
\text { value of } \\
\text { relation }\end{array}$ & $\begin{array}{l}(\mathrm{L} \leftrightarrow \mathrm{A}) \\
\text { Private autonomy to define } \\
\text { the best ways to manage } \\
\text { the asset life cycle }\end{array}$ & $\begin{array}{l}(\mathrm{G} \leftrightarrow \mathrm{L}) \\
\text { Public defines output } \\
\text { specifications, and private } \\
\text { defines the best ways to } \\
\text { achieve }\end{array}$ & $\begin{array}{l}(\mathrm{L} \leftrightarrow \mathrm{I}) \\
\text { Contracting upon the principle } \\
\text { who best manage risk }\end{array}$ \\
\hline
\end{tabular}


At this point, a distinction should be made between an analytical narrative or process of relational differentiation as the canonical type of explanation in critical realism, and narrative analysis as an interpretative method of empirical data. As an interpretative method, narrative analysis captures how informants impute meaning to their life experience by connecting different elements of a storyline told by them (Murray \& Sools, 2014). There are five storyline elements, namely (i) agent/character, (iii) acts/events, (iii) enablers/constraints, (iv) scene and (v) purpose/fear. The classic narrative starts with telling who the main agent in a setting/scene is, describing how the agent is in control or subject to circumstances given the gap between purpose/fear and means/hinders. The methodological assumption is that the storyteller produces a narrative to repair a breach between storyline elements, bringing to light the meaning of the situation/event re-called or experienced (so-called breach of meaning). From our perspective, a breach of meaning in a story told by an informant is the outcome of his/her reflection on the AGIL relations that he/she or other subjectively enact. Meaning captured by narrative analysis (as interpretative method) provides empirical support to define the direction in which actors and project facts move, reproducing or changing concessional PPP relationing described in terms of AGIL.

Accordingly, we identified episodes susceptible to be analyzed as a discrete narrative from the verbatim transcripts of project managers interviews (12 sessions). We used the interviews with internal public users, private lender advisors and public senior juridical advisors for triangulating information (6 sessions). In total, we identified 111 episodes in the stories told by project managers with meaning as a whole, susceptible to be analyzed as an independent narrative. We conducted the narrative analysis identifying the five elements for the 111 episodes taking as discrete storylines, defining the breach of meaning for each episode. After establishing the breach of meaning for each episode, we divided the 111 stories between three groups. One group of stories provided general information about the configuration of AGIL in accordance with the initial conditions of procurement for singular projects. The second group includes those episodes that described an event of interaction susceptible to be plotted over time, providing indications about the change and reproduction of AGIL relations for each project. The third group comprises episodes defining wider dynamics of change at organizational and field levels. The analytical tactics detail how 111 episodes were articulated with documental data. Together, they allowed us to empirically categorize AGIL initial configurations per project and their change or reproduction over time.

\subsubsection{Within-case Analysis}

The within-case analysis accounts for the initial configuration of positions in the PPP agreement in terms of AGIL components and the morphogenesis of AGIL components at the project level. First, we specified the initial PPP governance agreement for each project deviated or copied from the default PPP organizational receipt, considering the procurement context. We examined the policy discourse and reports as artefacts indicating the historical configuration of public-private governance relations at field level (Brunet, 2019). Hence, the policy discourse and reports reflected the relationing characterizing the different waves of PPP adoption in the Netherlands (Koppenjan \& de Jong, 2018). We compared the default organizational receipt in terms of relations between AGIL components of a PPP (Table 3.2), official documents, and episodes narrated by informants referring to the initial conditions during the procurement phase of each project. 
Once we had defined the initial temporary governance structure in terms of AGIL per project, we defined the number of paths according to our interpretation of the episodes told by the project managers. As each episode was analyzed in terms of the five storyline elements, they were grouped according to the scene/setting which in most of the cases was related to a contractual event (e.g. clarification of a contractual clause). Then, we checked the breach of meaning of all episodes that referred to the same contractual event. It allowed us to define which AGIL element was enacted or recreated by managerial activity. In some cases, the re-interpretation of the breach of meaning of all episodes related to one project only referred to the same AGIL component in a given project. In this case, the dynamics of the project was described as one relational path. In other cases, project dynamics refers to two or more analytical different AGIL components. Therefore, these projects included two or more paths of relational differentiation. For each relational path, we identified the number of morphogenetic cycles, reproducing or changing the initial project structure.

In order to characterize the strategic interaction in (T2-T3) for each cycle leading to T4, we followed Benitez-Avila et al. (2019). They situate governing interaction at the project level, considering the dual position of project managers at the temporary project and permanent organization. Each feedback details the interaction context in $\mathrm{T1}$, the trigger activating interaction, the demands and opportunities faced by actors due to their dual role at the temporary and permanent. Based on the breach of meaning of episodes relating to the same cycle, we made salient how actors articulated identities and interest when facing contradictory demands from their dual position. Likewise, we established the extent to which public and private managers were able to creatively enact the contractual and organizational demands opening the opportunity for changes at the project level. As a conclusion, each cycle analysis included the change or reproduction of the situation logics and the description of (re)production of AGIL for T4. We used the extended categorization introduced by (Donati, 2013) for characterizing the outcome for T4.

We defined that pure morphostasis occurs when the interaction in T2-T3 reproduces the initial or ongoing relationing blueprint in terms of AGIL, leading to an identical governance structure due to the enforcement of existing contractual entitlements or reproduction of governing practices $(X \rightarrow Y S)$. We established developmental morphogenesis when the interaction in T2-T3 leads to a variation of the contractual forms or the emergence of new governing practices adapting to new circumstances, leading to the reinforcement of the initial or ongoing relationing blueprint $(X \rightarrow Y D)$. Pure interactional morphogenesis was established when the interaction in T2-T3 challenges the initial or ongoing relationing basis, but it is not stable enough for introducing an alternative relationing. Finally, we defined pure morphogenesis for cycles whose outcomes lead to a fundamental modification of the initial or ongoing relationing embedded in the contract $(X \rightarrow Y G)$.

\subsubsection{Analysis of the Contextual Embeddedness}

This analysis situates the divergence or similarity between projects in relation to the broader organizational and field dynamics. In other words, the analysis made an effort to describe and explain project divergence and similarity within the broader and more permanent organizational systems. (Vincent \& Wapshott, 2014, p. 161). We examined how the patterns of interaction at the project level evolved in the same or different direction than the policy discourse of the procurement agency. We considered the initial procurement context and contractual activity modifying the PPP structure of 
relations at the project level over time. To support our interpretations, we referred to the existing literature of PPPs in the Netherlands and the historical evolution of the construction market, as well as public reports available in specialized infrastructure Dutch media and policy documents. The comparison of projects in their respective context provides a historical narrative based on the light theorization by selecting-for-difference (Kessler \& Bach, 2014). Meaning, our expectation that historical procurement moment accounted for the path of change and reproduction of the project governance structures and governing practices. Therefore, the analysis of the contextual embeddedness brings to light (i.) to which extent the governance structures within the projects changed as a result of changes in the governance structures at organizational and field level (upwards causation) and (ii.) to which extent change of governance structures at organizational and field levels was informed by governing activities at project level (downwards causation). Finally, we aimed to define the role of agency of public project managers as a group with vested interest emerging but not reduced to their organizational role in the permanent and temporary organizing.

\subsection{RESULTS}

\subsubsection{Case 1: N31 Strong Collaboration in a Partnership}

The N31 case was regarded as highly satisfactory by informants, usually portrayed as a benchmark of collaboration for projects with similar characteristics. The working dynamics were captured by public project manager opinion referring to the counterpart: "We almost work as an alliance". As a pilot project, the N31 project was procured in the second wave of DBFM in the Netherlands under the principle "more value through collaboration". On the one hand, the contract included a regular PPP mechanism to introduce efficiency through bundling life-cycle cost, indexing payments to availability and private financing. On the other hand, the choice of the DBFM form and procurement process considered financial considerations as a subsidiary of public-private learning and collaboration. The subsidiary emphasis on VfM is acknowledged by the project manager stating that the project "cost a little bit of [more] money than expected, but we made it a success". The private asset manager recognized that the N31 contractual provisions are less demanding for the contractor in comparison to other DBFM contracts in the Netherlands. In this regard, the procurement process for the N31 placed less emphasis on efficiency as criteria of adaptability in comparison to the default PPP. Rather than defining the value of the relationship emerging from the discrete allocation of responsibilities and autonomy ( $L$ from AGIL), the initial conditions emphasized close cooperation. Table 3.3 summarizes the relations of AGIL components in the procurement of N31.

There is one path of relational differentiation that brings together two consecutive developmental morphogenetic cycles leading to one morphostatic cycle at the project level. The outcome of this path counteracted the penalty regime adopted from the default PPP relationing $(G \leftrightarrow I)$, while it reinforced the emphasis on collaboration softening private autonomy during the procurement phase $(L \leftrightarrow A)$. Table 3.4 details the path of relational differentiation. 
Table 3.3 Second-order AGIL relations characterizing the embedded relationing in the N33 project (2002)

\begin{tabular}{|c|c|c|c|}
\hline & (A) Efficiency & (G) Efficacy & (I) Normative \\
\hline (G) Efficacy & $\begin{array}{l}\text { ( } G \leftrightarrow A) \\
\text { Long term value for money } \\
(V f M) \text { is subsidiary to close } \\
\text { collaboration }\end{array}$ & & \\
\hline (I) Normative & $\begin{array}{l}(\mathrm{I} \leftrightarrow \mathrm{A}) \\
\text { Banks assess emergent risks } \\
\text { from life-cycle cost. }\end{array}$ & $\begin{array}{l}(\mathrm{G} \leftrightarrow \mathrm{I}) \\
\text { Government activates penalties } \\
\text { given service/availability; }\end{array}$ & \\
\hline $\begin{array}{l}\text { (L) Intrinsic } \\
\text { value of } \\
\text { relation }\end{array}$ & $\begin{array}{l}(\mathrm{L} \leftrightarrow \mathrm{A}) \text {. } \\
\text { Private autonomy to define } \\
\text { the best ways to manage the } \\
\text { asset life cycle is subsidiary to } \\
\text { close collaboration }\end{array}$ & $\begin{array}{l}(G \leftrightarrow L) \\
\text { Public defines output } \\
\text { specifications while private } \\
\text { defines the best ways to } \\
\text { achieve them subsidiary to } \\
\text { close collaboration }\end{array}$ & $\begin{array}{l}(\mathrm{L} \leftrightarrow \mathrm{I}) \\
\text { Contracting upon the principle } \\
\text { whoever best manages } \\
\text { risk is subsidiary to close } \\
\text { collaboration }\end{array}$ \\
\hline
\end{tabular}

The first N31 ${ }_{(1)}$ cycle softened the penalty regime $(G \leftrightarrow I)$ and private autonomy $(A \leftrightarrow L)$. It further developed the initial relationing based on more value through collaboration $(X \rightarrow Y D)$. In this episode, actors were confronted with a hidden defect due to a construction mistake. As DBFM entitled the contractor with managerial autonomy to deal with construction risk ( $\leftrightarrow \leftrightarrow L$ ), it could have claimed that the mistake was not urgent to address. In the words of the private project manager, they had the chance to enforce private autonomy: "as long as today [the hidden defect] is not a problem, we [the contractor] do not have to do it [reparations] today". Plus, addressing the problem would have implied a reduction in the availability fee for the contractor. Repairing it would cost one million, but the time used for repairing would have doubled the losses. Nevertheless, the initial emphasis on cooperation over autonomy and commercial interest enabled an open conversation for reaching a compromise. The private party accepted to address the issue as soon as possible, while the penalty was waived. This episode revealed the necessary contradiction between the cultural value attributed to the relationship by the time being of "value through collaboration" and the normative configuration of the DBFM mechanism linked to availability ( $G \leftrightarrow I)$. This necessary contradiction was concealed by prioritizing the former over the latter, framing the contractual duty in terms of delivering service for a reasonable price rather than enacting legal clauses. This creative enactment of the contractual relation led to the development of trust as relational good providing the grounds of future interaction.

The N31 $1_{(2)}$ and $N 31_{(3)}$ cycles reinforced the idea that compliance-seeking exchange would not resolve issues and priority should be given to more value through collaboration rather than to the normative requirements linked to efficacy $(G \leftrightarrow 1)$. The $N 31_{(2)}$ cycle developed the initial relationing based on more value through collaboration $(X \rightarrow Y D$ ). This cycle was activated by the emergence of sedimentation problems that could constitute a major issue when transferring the road back to HA at the end of the contract. Similar to the previous problem, there was space for claiming that the sedimentation problem was not an urgent problem. However, the symbolic value of the project as an example of collaboration provided grounds for finding a solution before examining contractual entitlements. However, there was neither a clear scope of the problem nor responsibilities and extra cost to solve it. At the time of collecting data, both sides were considering escalating the problem to a tribunal $\left(\mathrm{N} 31_{(3)}\right)$, but the 


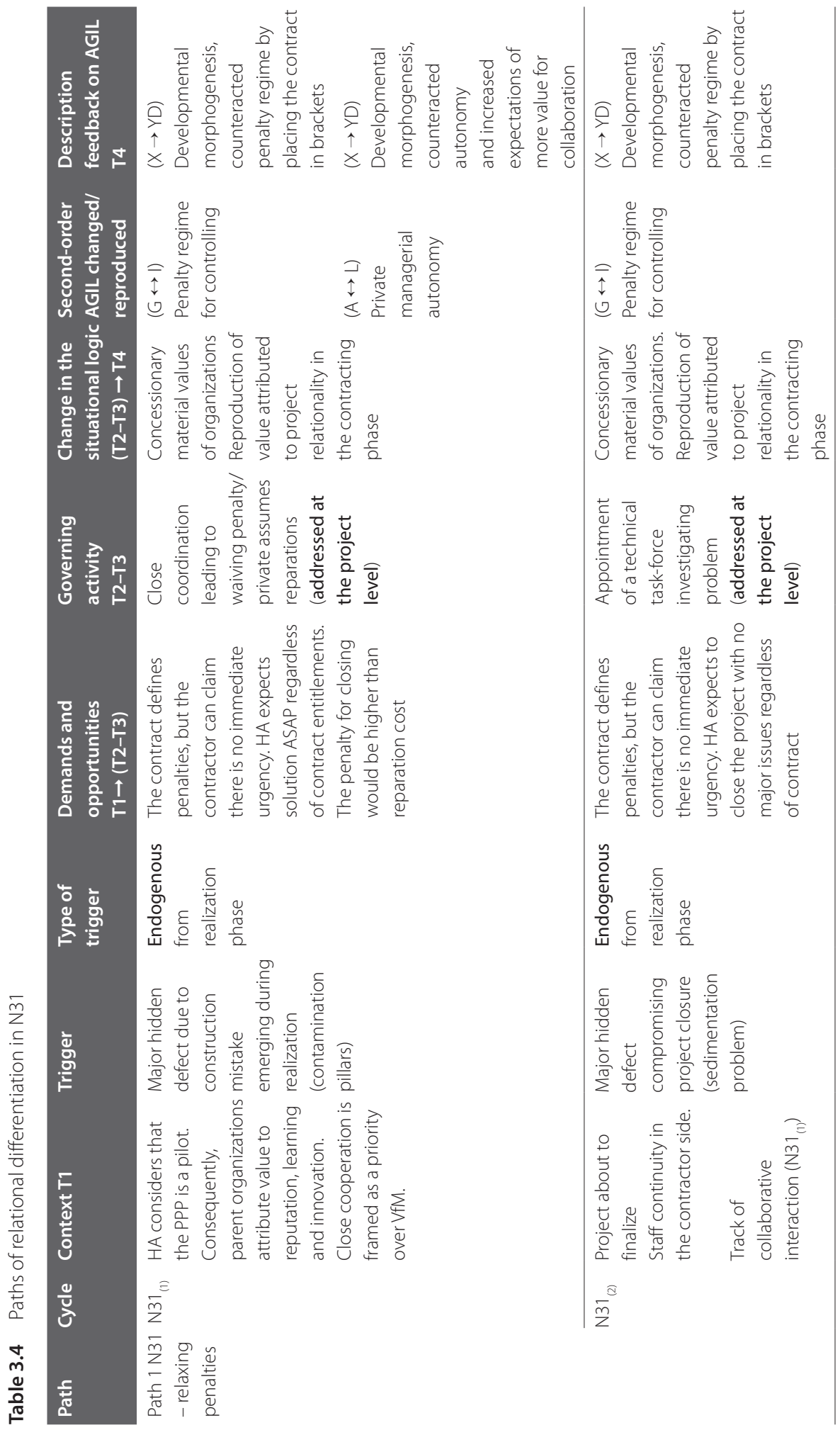




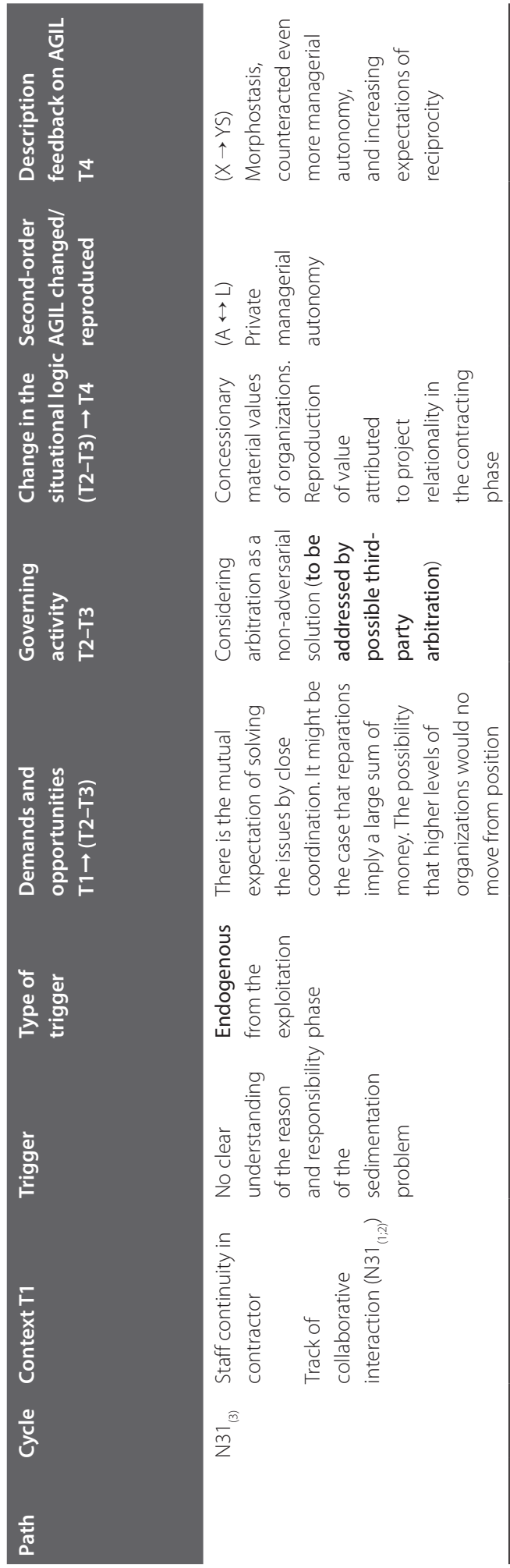


appeal of arbitration was not framed in adversarial terms. The relationship built upon the principle of more value through collaboration enabled framing escalation as a necessary conflict resolution measure when organizational stakes do not allow project managers to provide additional concessions. Therefore, $N 31_{(3)}$ reproduced the existing elements of the relationing $(X \rightarrow Y S)$. It is important to point out that even in this paradigmatic case of the N31 project, the high personnel turnover within the HA leads to a type of relationing not free from the risk of relational evils. In this case, the asymmetric level of expertise and information accumulated by the private operation manager is a definite disadvantage for the novice public contract manager. As she explained: "it is the contractor who defines the way it goes".

\subsubsection{Case 2: II Coen Tunnel: Common Ground for Addressing Problems in a Working Relationship}

The II Coen Tunnel was regarded as a project whose acceptable levels of collaboration during the maintenance phase contrasted to the severe conflicts during the tendering and construction phases. The ongoing working dynamics were best captured by the public contract manager: "I can 't say we are a team, but we can understand each other well enough to agree on some issues." The Coen Tunnel contract was the first DBFM contract procured by competitive dialogue during the third wave of DBFM adoption in the Netherlands (Hoezen, 2012; Volker \& Hoezen, 2017). The competitive dialogue procedure awarded points to the bidder who accepted a higher number of risk to be transferred by the HA. Additionally, the HA adopted the "market unless principle" as a policy for the delivery of public infrastructure. This principle heavily relied on strong market autonomy for the delivery of public infrastructure service. The retrospective opinion of the public project manager illustrates the expected advantages of transferring all risks to the market. The DBFM contract "was always marketed as contracts without concern. You say what you want, they designed and build for the next 30 years, and what you get is a super project". Along these lines, the procurement practice of the II Coen Tunnel was based on the assumption that the market would select the risks that they can assume in the competitive dialogue. In this regard, the embedded relationing in the project placed a strong emphasis on the market capacity to assume risks $(L \leftrightarrow I)$. As indicated in Table 3.5, there was a stronger emphasis on private autonomy to manage an asset life cycle $(L \leftrightarrow A)$ and define the ways to achieve public goals $(G \leftrightarrow I)$.

Table 3.5 Second-order AGIL relations characterizing the embedded relationing in the II Coen Tunnel (2005)

\begin{tabular}{|c|c|c|c|}
\hline & (A) Efficiency & (G) Efficacy & (I) Normative \\
\hline (G) Efficacy & $\begin{array}{l}(\mathrm{G} \leftrightarrow \mathrm{A}) \\
\text { Long term value for money } \\
(\mathrm{VfM})\end{array}$ & & \\
\hline (I) Normative & $\begin{array}{l}(\mathrm{I} \leftrightarrow \mathrm{A}) \\
\text { Banks assess emergent risks } \\
\text { from life-cycle cost. }\end{array}$ & $\begin{array}{l}(\mathrm{G} \leftrightarrow \mathrm{I}) \\
\text { Government activates penalties } \\
\text { given service/availability; }\end{array}$ & \\
\hline $\begin{array}{l}(\mathrm{L}) \text { Intrinsic } \\
\text { value of } \\
\text { relation }\end{array}$ & $\begin{array}{l}(\mathrm{L} \leftrightarrow \mathrm{A}) \text {. } \\
\text { Strong emphasis on private } \\
\text { autonomy to define the best } \\
\text { ways to manage the asset life } \\
\text { cycle }\end{array}$ & $\begin{array}{l}(\mathrm{G} \leftrightarrow \mathrm{L}) \\
\text { Strong emphasis on Public } \\
\text { defines output specifications } \\
\text { and private defines the best } \\
\text { way to achieve them }\end{array}$ & $\begin{array}{l}(\mathrm{L} \leftrightarrow \mathrm{I}) \\
\text { Contracting upon the principle } \\
\text { who best manage risk is driven } \\
\text { by "market-knows-best" }\end{array}$ \\
\hline
\end{tabular}


Previous research already reported on adversarial interaction during the tendering phase: "Negative attitudes to each other [were] based on a conflict that occurred in the time between the final bid and the contract award" (Volker \& Hoezen, 2017, p. 99). After the awarding phase, private and public staff moved to other projects as their expertise was only needed for the initialization of the project and was required for new projects. Although the change of people allowed to clear the air (Volker and Hoezen (2017), our analysis revealed that the risk allocation set the scene of the relationship between contractor and HA during the implementation of the project. In particular, the project evolved along three paths (Table 3.6). The first path was initiated by a strong conflict emerging from the excessive reliance on market forces to optimize risk allocation $(L \leftrightarrow I)$. It comprised one cycle counterbalancing strong private autonomy $(L \leftrightarrow A)$, changing relationality and setting the background for the second and third path. The second path adjusted the system of penalties because of contractual ambiguities and emerging opportunities to reduce contractor risk and life-cycle cost $(G \leftrightarrow I)$. The third path was related to the introduction of changes to asset functionality. It counteracted the strong private autonomy for defining the best way to reach public goals ( $G \leftrightarrow$ I) but reinforced financial discipline imposed by lenders $(\mathrm{I} \leftrightarrow \mathrm{A})$. The second and third paths unfolded simultaneously in the sense that contractual events were intercalated.

The first path strongly counterbalanced the emphasis on private autonomy ( $A \leftrightarrow L$ ), by bringing managerial responsibilities back to the HA after arbitration. This path only included one pure morphogenetic cycle $(X \rightarrow Y D)$. The triggering conflict was the reliability measures requested by the municipality to open the tunnel. Acquiring this authorization implied higher safety requirements than the ones explicitly defined under the DBFM availability requirements. As the public contract manager explained: "we asked this contractor about availability, and the permits required reliability". Then, the discussion was on the extent to which availability of the tunnel meant getting the tunnel open, and therefore, transferring the risk of acquiring permits for building the tunnel. The same informant illustrated the material conflict for the contractor of acquiring the permits: "(..) in availability you run the risk that something is getting broken, and reliability asks for the lowest possibility of failure (...) the contractor can calculate the amount of time non-available and get the penalty (...) and these penalties will be less expensive than investing in reliability". The HA argued that transferring stakeholder management also included buying the reliability requirements of the municipality. That is what the commercial parties referred to as the "Bahamas model"20, a situation in which the private contractor assumes all risks even when the public could have helped. Tensions decreased after the arbitration and realization phase, although the system of penalties required clarifications and the realization phase led to losses for both parties. The arbitration operated as a tipping point, resolving the contradictions between the excessive reliance on private managerial autonomy conflicting with a strong regulatory environment. The HA assumed a higher number of responsibilities in terms of operative coordination, fundamentally changing the Bahamas model relationing.

\footnotetext{
${ }^{20}$ The so-called "Bahamas model" emerged in the specialized media and discussion forums of the Dutch construction sector in the early 2000. In the Congress Infra-Tunnel which took place between April 4-5, 2001 this label was used to make salient the negative implications of excessive reliance on transferring risk to the market. "In the Bahama model, the influence of the client on the construction process is reduced to the basic announcement of his expectations to the builder"(Molenar \& Wijnants, 2001, p. 66). In consequence, there are two extremes "the contractor is totally not responsible or liable. This means that the client must design, check quality, etc. The other extreme is the "Bahamas model". The client can go on holiday to the Bahamas and can return and the tunnel is ready and meets all requirements" (Molenar \& Wijnants, 2001, p. 14)
} 


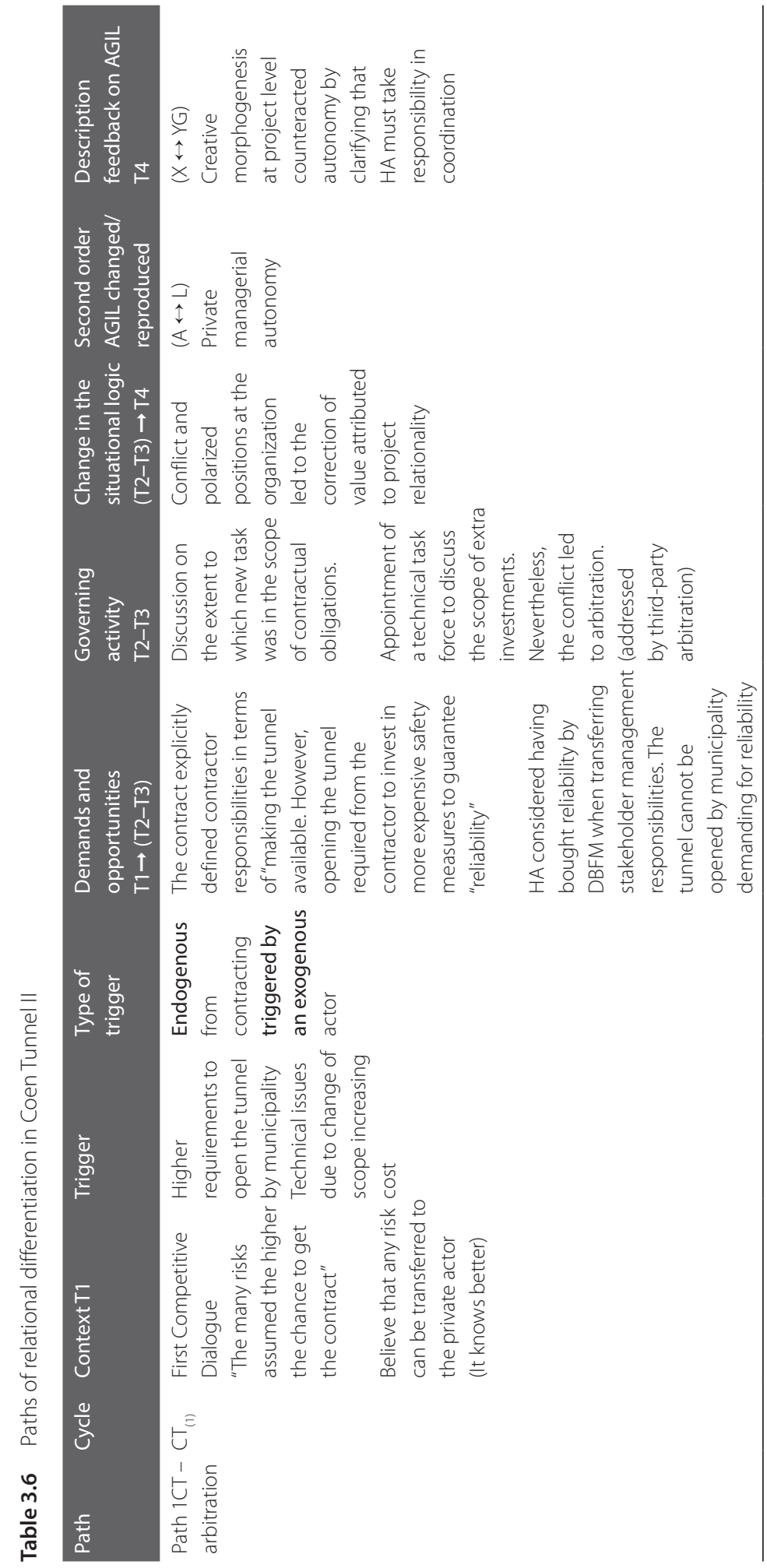




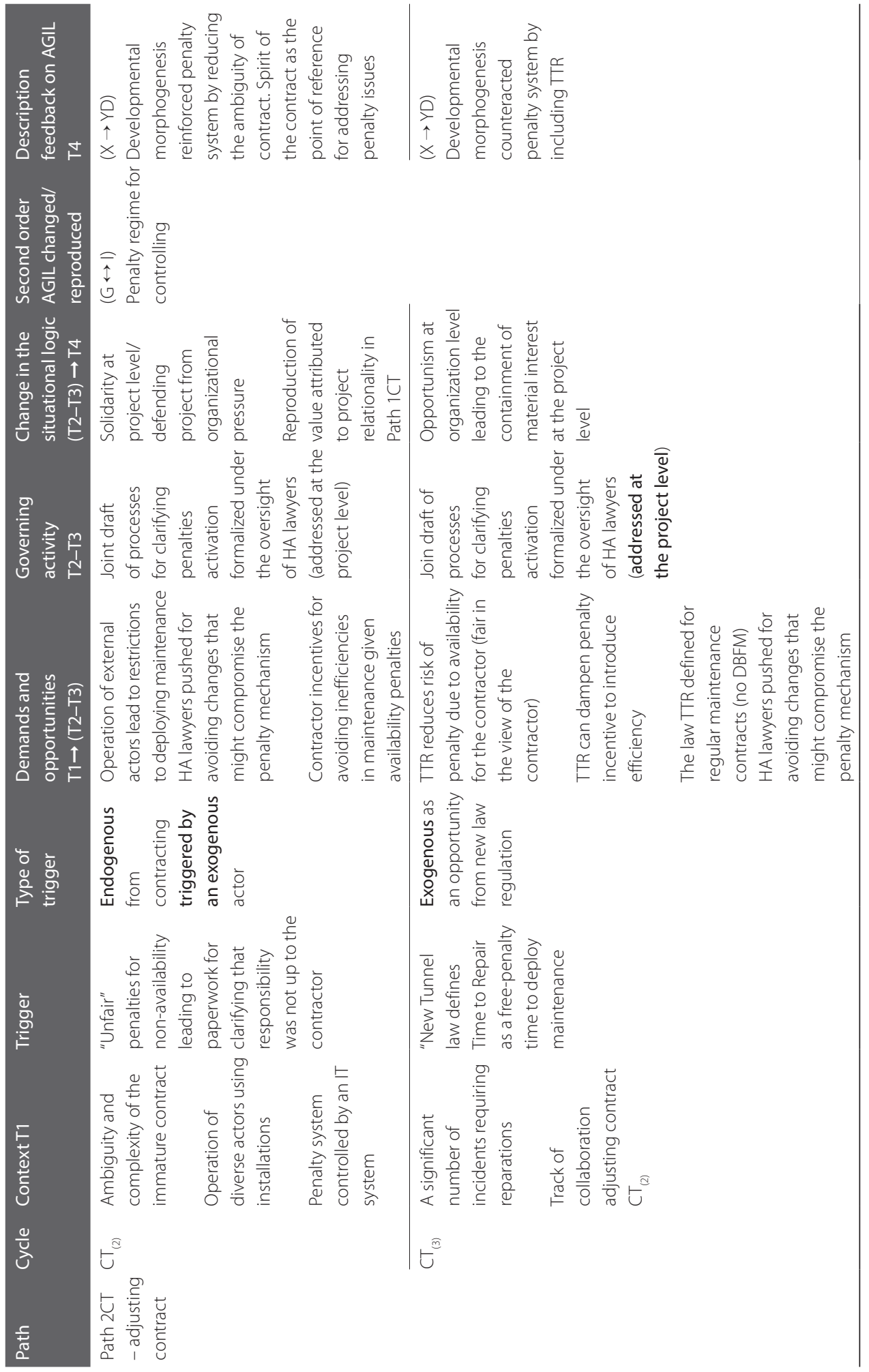




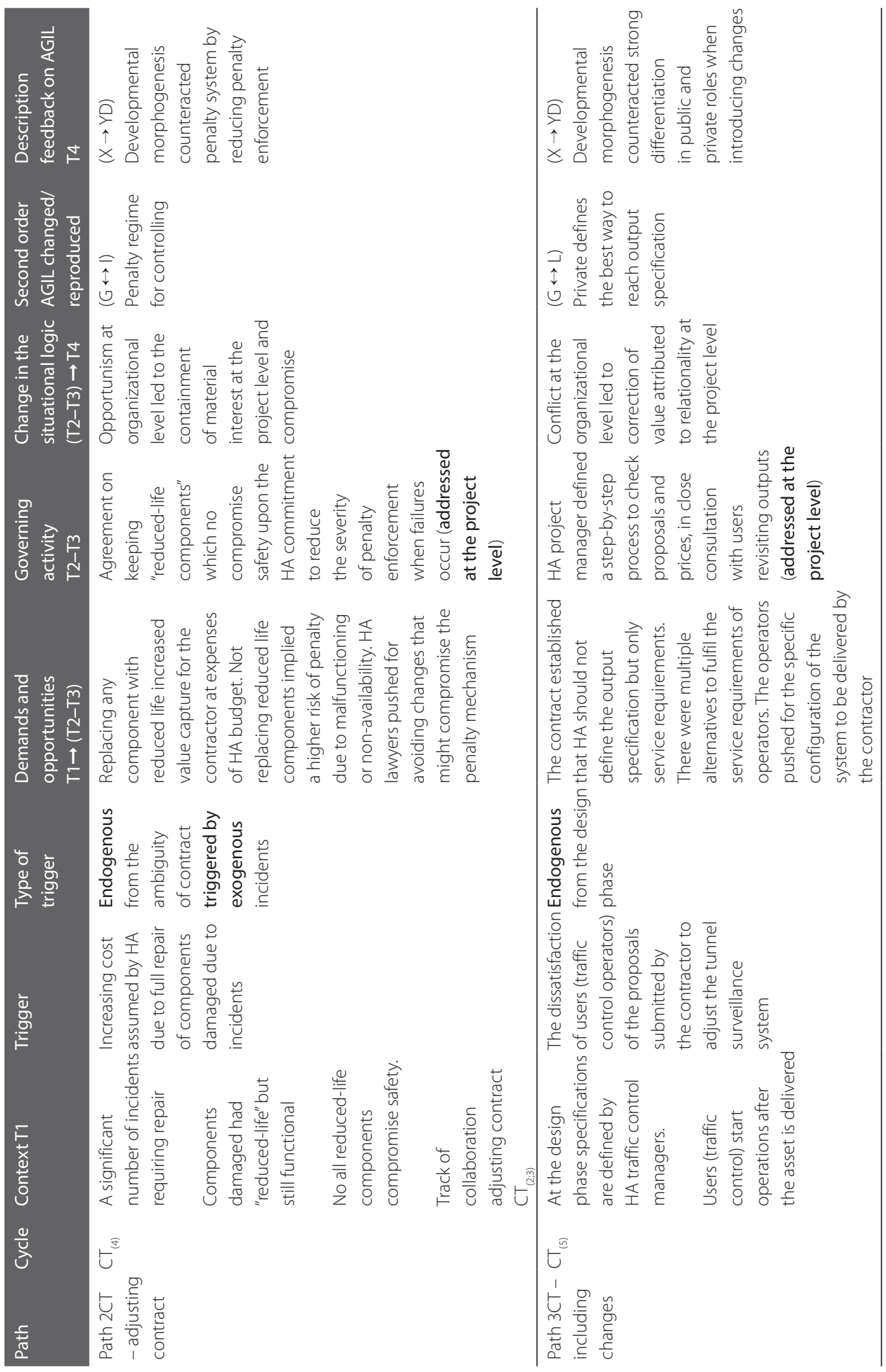




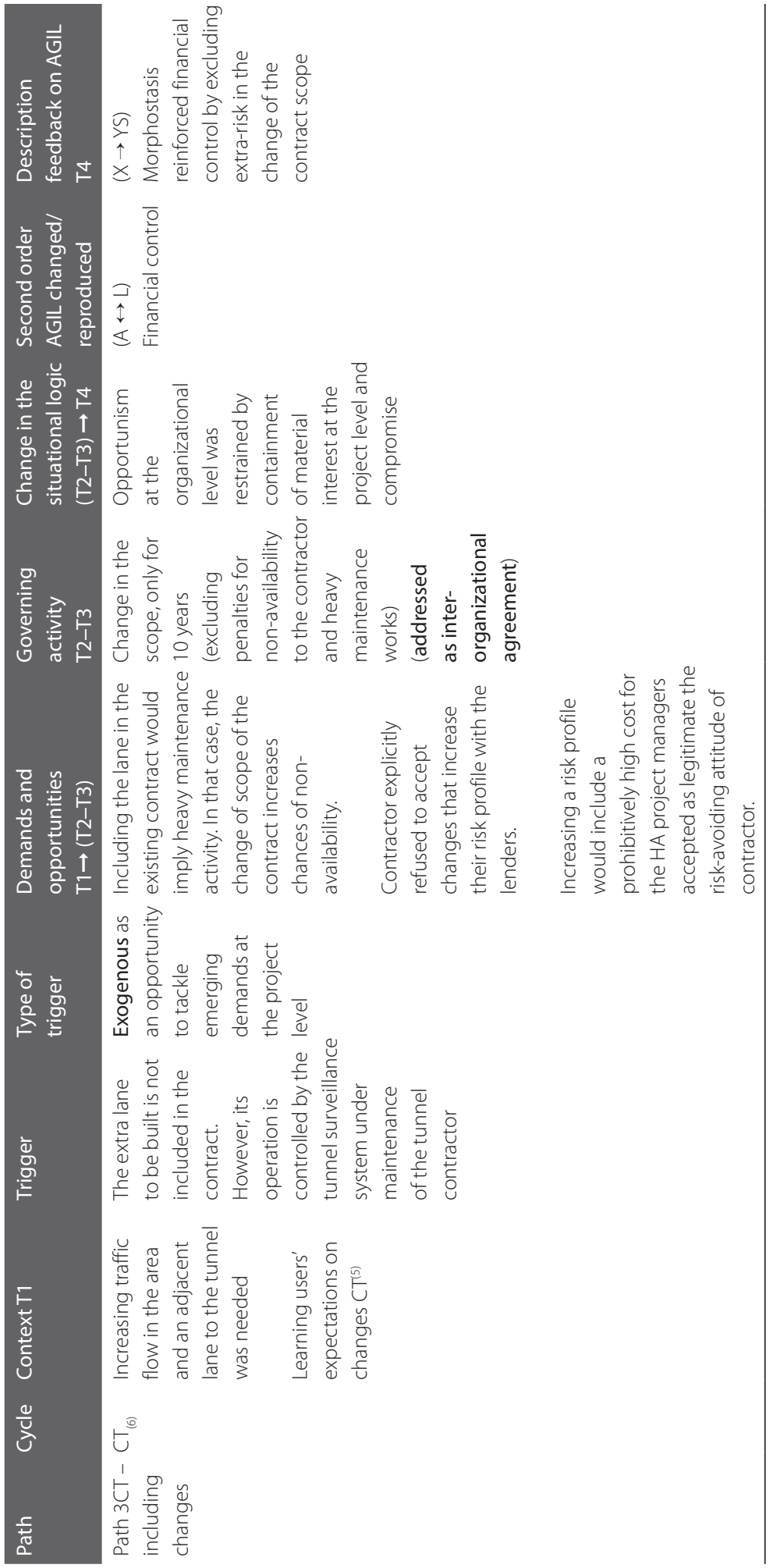


Path 2CT emerged in the new relationing framework of shared operative coordination, under the mutual recognition of contractual ambiguity and misspecifications. The governing activity in cycles $C T_{(2)^{\prime}} \mathrm{CT}_{(3)^{\prime}}$ and $\mathrm{CT}$ (4) adjusted the regime of penalties and rewards $(\mathrm{G} \leftrightarrow \mathrm{I})$. As the public contract manager explained, in $\mathrm{CT}_{(2)}$, and $\mathrm{CT}_{(3)}$ managers went beyond the letter of the contract "one level higher" to build a mutual understanding of penalty systems based on "the meaning of the contract". In $\mathrm{CT}_{(4)}$, the attenuation of the penalty enforcement was guided by a utilitarian exchange, where the HA obtained a lower price for the repair of components damaged in accidents. Overall, the 2CT path unfolded upon the shift of relationing in $\mathrm{CT}_{(1)}$ aimed to assess conflictive interests and reach compromises at project level $(X \rightarrow Y G)$. These compromises had to be defended by the public project manager at the parent organization level. The contractual modifications had to be examined by the lawyers of the HA in charge of maintaining the integrity of DBFM contracting. In this regard, the public contract manager explained that he shared the same interest with the private counterpart at the project level, and "conspired" to push the interest of the project forward in their parent organizations.

Path 3CT counteracted the strong differentiation in public-private roles for introducing services changes $(G \leftrightarrow I)$ and reinforced the financial control mechanism $(A \leftrightarrow I)$. Similar to the 2CT path, public and private project managers sometimes shared the interest concerning external actors. In other episodes, their interaction aimed at containing the material interests of the counterpart. Service changes in an ongoing contractual relationship typically imply a monopolist-like situation acknowledged by the private contract manager. "If you ask five contractors to bid on the tender, you will get a better price. But, if you get one, we are the only one within the area that carry out the works." In a DBFM setting, the HA can only define "functional specifications" of a change. The contractor is entitled to define the best means for meeting the change request, including the life-cycle cost. When a change was priced "unexpectedly high" in $\mathrm{CT}_{(5)^{\prime}}$ the HA had objective grounds for whether the contractor was overcharging. In other cases, the final user was not satisfied with the solution provided by the contractor. Then, public and private actors collaborated to contain user demands exceeding the contractual scope. The outcome of the $\mathrm{CT}_{(5)}$ cycle included an extra-contractual procedure to jointly clarify mutual expectations and prices further developing the relationing emerging from $C T_{(1)}(X \rightarrow Y G)$. Yet, negotiation of prices unfolded upon the common understanding that no decision can increase the SPV risk profile. That is why in $\mathrm{CT}_{(6)}$ the decision includes the extra lane in the existing contract, but excludes heavy maintenance that would increase the risk profile of the SPV for the lenders. The private contract manager explained that "[public project manager] knows the condition we had to our lenders. So, if we have a problem with our lenders, RWS would also have a problem with them". The outcome of cycle $\mathrm{CT}_{(6)}$ enforced the lenders' control, thus leading to morphostasis of financial discipline $(X \rightarrow Y S)$.

\subsubsection{Case 3: N33 Tense interaction Upon a Contractual Relationship}

The N33 case was regarded as a project where project actors struggled to overcome existing tensions. The opinion of the public contract manager commenting the results of a team-building session with the counterpart illustrated the existing working relationship. "We said that certain things are important like trusting each other ... and then we left the room and that's it... from my feeling, it does not feel good, yet". The N33 project gained attention as one of the first engagement of pension funds investing in the delivery of large infrastructure (Bennon, Monk, \& Nowacki, 2015; Matos-Castaño et al., 2014). The interest in reaching institutional investors was to bridge the public financial gap and increase 
the value-for-money in the context of economic crisis. The emphasis on introducing efficiency during the procurement phase is a situation acknowledged by the current HA contract manager, who characterized the procurement as "pure economic transaction". Accordingly, the embedded relationing in N33 reflects the default components of a concessional PPP with a stronger emphasis on value-for-money (Table 3.7).

Table 3.7 Second-order AGIL relations characterizing the embedded relationing in the N33 project (2011)

\begin{tabular}{|c|c|c|c|}
\hline & (A) Efficiency & (G) Efficacy & (I) Normative \\
\hline (G) Efficacy & $\begin{array}{l}(G \leftrightarrow A) \\
\text { Emphasis on efficiency for } \\
\text { the long term value for money } \\
(V f M)\end{array}$ & & \\
\hline (I) Normative & $\begin{array}{l}(\mathrm{H} \mathrm{A}) \\
\text { Banks assess emergent risks } \\
\text { from life-cycle cost. }\end{array}$ & $\begin{array}{l}(G \leftrightarrow l) \\
\text { Government activates penalties } \\
\text { given service/availability; }\end{array}$ & \\
\hline $\begin{array}{l}(\mathrm{L}) \text { Intrinsic } \\
\text { value of } \\
\text { relation }\end{array}$ & $\begin{array}{l}(\mathrm{L} \leftrightarrow \mathrm{A}) \text {. } \\
\text { Private autonomy to define } \\
\text { the best ways to manage the } \\
\text { asset life cycle }\end{array}$ & $\begin{array}{l}(G \leftrightarrow L) \\
\text { Public defines output } \\
\text { specifications, and private } \\
\text { defines the best way to } \\
\text { achieve them }\end{array}$ & $\begin{array}{l}(\mathrm{L} \leftrightarrow \mathrm{l}) \\
\text { Contracting upon the principle } \\
\text { whoever best manages risk }\end{array}$ \\
\hline
\end{tabular}

The project evolved along two paths of differentiation. The first one relates to an emerging conflict with the municipality and province due to a project agreement that optimized maintenance works from an economic and safety perspective but ignored the nuisance to residents. This path includes two cycles (Table 3.8), which reinforced the autonomy of the private contractor $(L \leftrightarrow A)$. The second path relates to the escalation of tension by resorting to the letter of the contract, rather than engaging in an open conversation about the ways to solve problems beyond contractual entitlements. In consequence, it reinforced the interaction upon enactment of rewards and penalties according to the contract $(L \leftrightarrow G)$.

The first path emerged with the compromise between the contractor and the HA to close over cost for fifteen parts of the construction assignment. As a part of the friendly settlement, the agreement included the "optimization" of the annual maintenance schedule $(A \leftrightarrow G)$. This optimization included closing the road for three weekends in spring and autumn, reducing the risk of non-compliance and safety concerns for the maintenance crew. The N33 ${ }_{(1)}$ cycle further developed the relationing based on prioritizing efficiency $(X \rightarrow Y D)$, allowing the contractor to cut down the amount of money requested from the HA. However, the compromise between contractor and HA led to negative consequences for the wider network in N33 ${ }_{(2)}$, including provinces and municipalities, which also contributed to the N33 funding. In particular, the traffic was diverted to secondary and tertiary roads increasing dissatisfaction of residents complaining to local authorities. Not having a clear alternative, the head of the district of the HA supported maintenance optimization formalized in the agreement reinforcing, even more, contractor autonomy for optimizing maintenance activities ( $A \leftrightarrow L$ ). The discussion reached a dead end where both $\mathrm{HA}$ and contractor found themselves under the need to contain the pressure by the province and the municipalities. At the moment of collecting data, the province and the municipality continued pushing the highest levels of the national HA for another solution $(\mathrm{X} \rightarrow \mathrm{YI})$. 


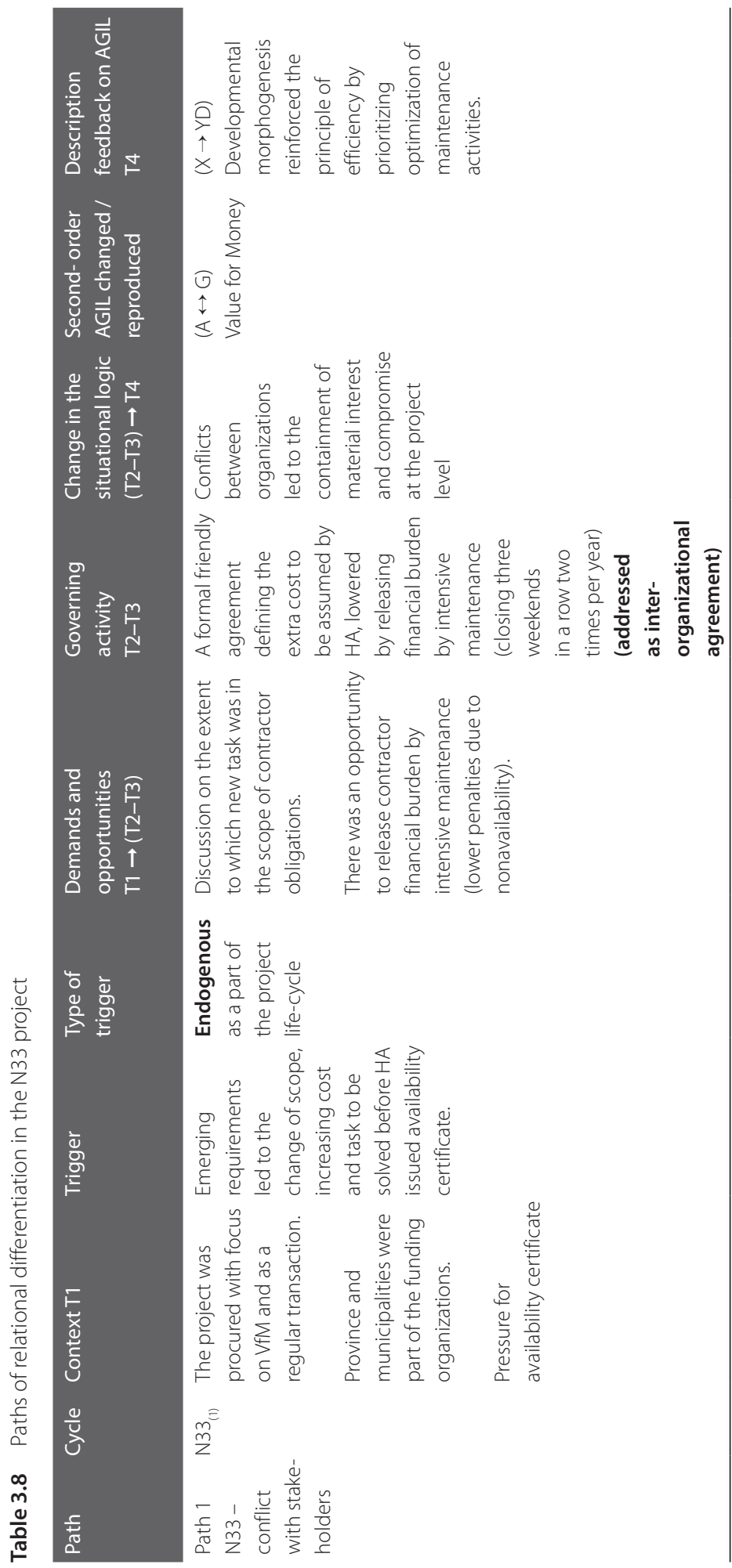




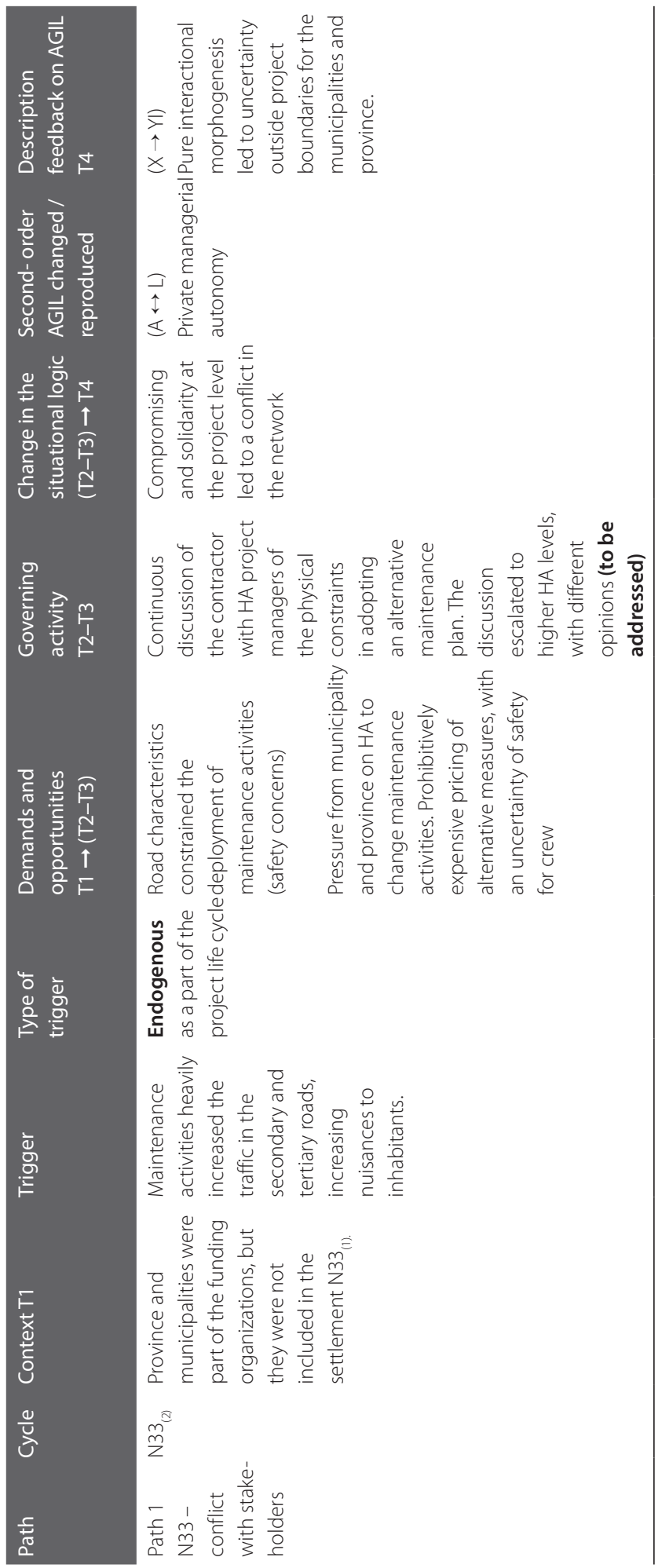




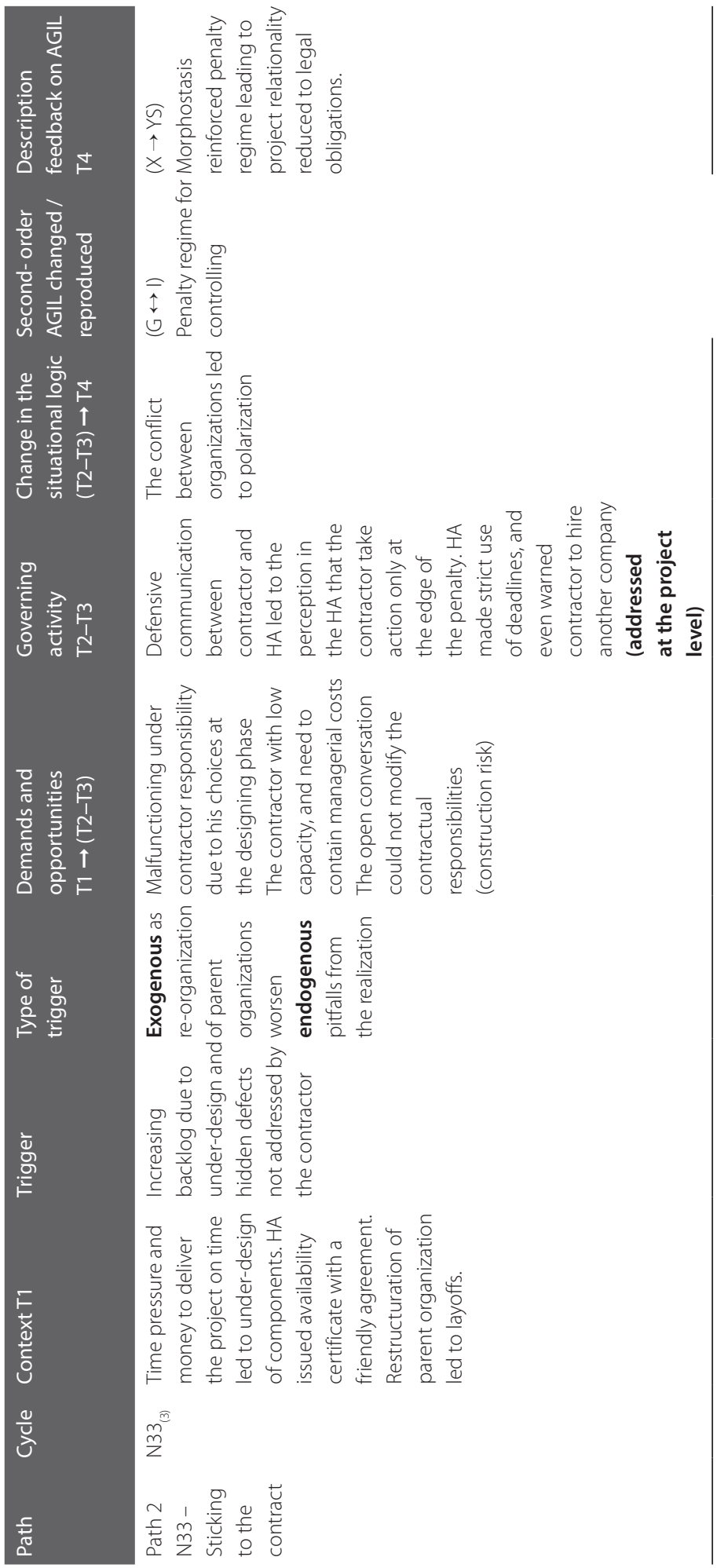




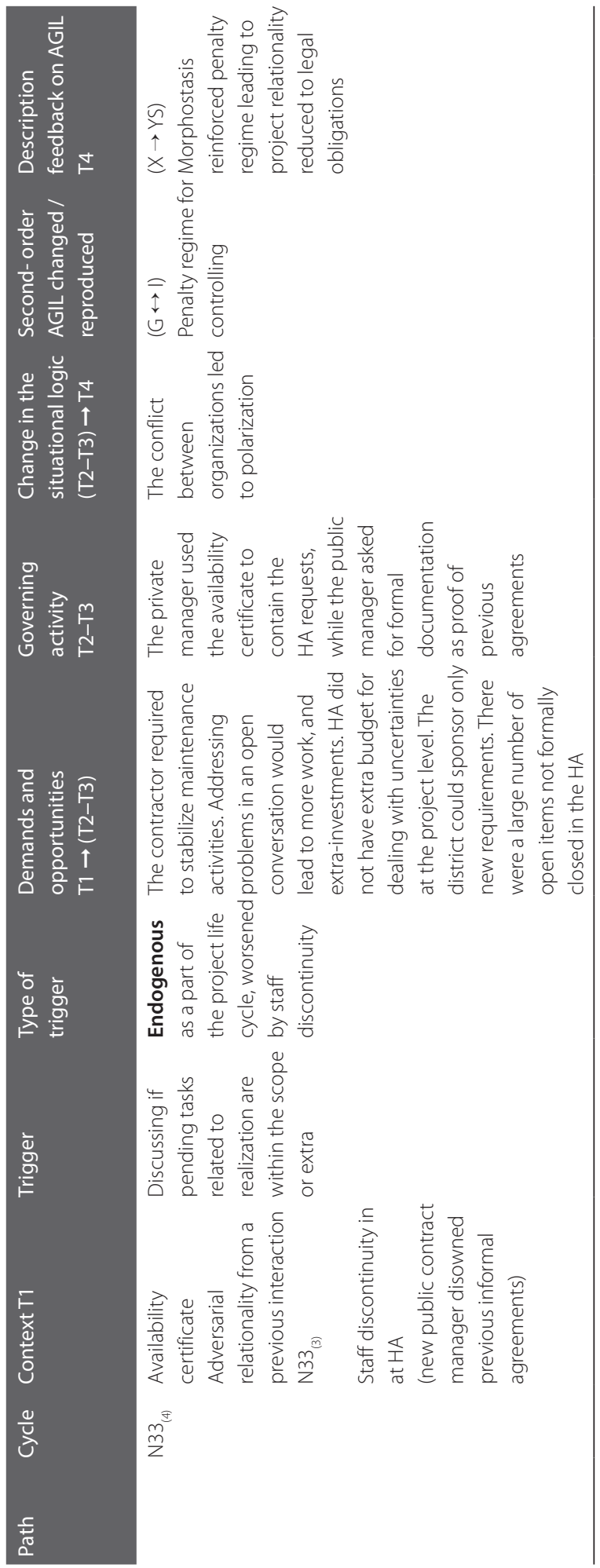


The second N33 path had as a context the lack of relational grounds to address project issues beyond contractual entitlements, which provided high autonomy of the contractor to optimize capital investments and exploitation risk. When the future unfolded against the cost-saving measures

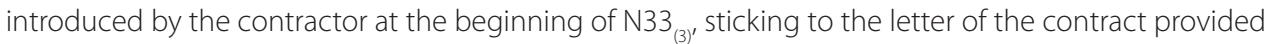
the last resource to minimize losses $(G \leftrightarrow I)$. The emblematic issue was the KB28 bridge at Zuidbroek whose security software was not properly designed, with the result that safety procedures started to run at the slightest disturbance. The bridge malfunctioning was a clear responsibility of the consortium (under their risk). However, the massive layoffs in 2016 in the contractor parent organization negatively impacted the workforce capacity to solve the defect. The continuous staff change at the HA limited, even more, the possibilities to develop a working relationship beyond contractual entitlements. In other words, the actors were not able to base their working expectations besides the contractual allocation of responsibilities leading to morphostasis of the initial relationing ( $X \rightarrow Y S)$.

The interaction in $\mathrm{N33}_{(4)}$ had as background a struggle to define the extent to which issues during the maintenance phase were open items of change in the scope. From the perspective of the public contract manager, there were contractual items not properly addressed according to the procedure. Most of them were informal agreements between the contractor and the former public contract manager. The claim that past issues should be reviewed, arguing lack of a proper formal closure reinforced interaction upon contract enforcement as the sole basis for working relations $(G \leftrightarrow I)$. In turn, the vested interest of the contractor was reducing the space of dialogue as "[the public manager] cannot talk about the realization of the road [...] because [HA] gave me the certificate, and I [the contractor] want to go on now". Additionally, the N33 contract did not allocate extra budget for these contingencies, nor did the HA have extra budget for the project. This situation put the public contract manager in an uneasy position of going through a cumbersome procedure for raising extra money. The large chain of authorizations within the HA differed from the logic of the contractor organization, where it was clearer who is responsible. From the perspective of the private manager, "if there is no back-up within the HA, it more or less becomes my problem. And it is a very strange situation". Overall, the N33 ${ }_{(4)}$ reinforced the penalty regime and, thus, the project relationality was reduced to legal obligations (XYS).

\subsubsection{Analysis of the Contextual Embeddedness}

As expected in our light theorization, governing managerial activity at project level was predisposed by the public-private relationality that, for the time being, characterized procurement policy. In all cases, the governing and governance interplay changed or reproduced the contractual penalties upon levels of service $(G \leftrightarrow I)$ and the principle of autonomy according to which private parties define the best ways to manage the asset life cycle (A $\leftrightarrow \mathrm{L}$ ). Nevertheless, the process and outcomes of change diverged due to strong path dependence effects defined by the initial conditions. For a more detailed theorization of the temporary and permanent interface, Figure 3.1 situates public-private relationing at the project level in relation to the broader organizational and field dynamics. In particular, it allows us to illustrate four points: (1) to which extent relationing at project level changed as it did at field and organizational level, (2) to which extent the governance structures within the projects changed as a result of changes in the governance structures at the organizational and the field level, (3) to which extent change of governance structures at organizational and the field level was informed by 
governing activities at project level, and (4) the role of project managerial agency in the temporary and permanent organizing interface.

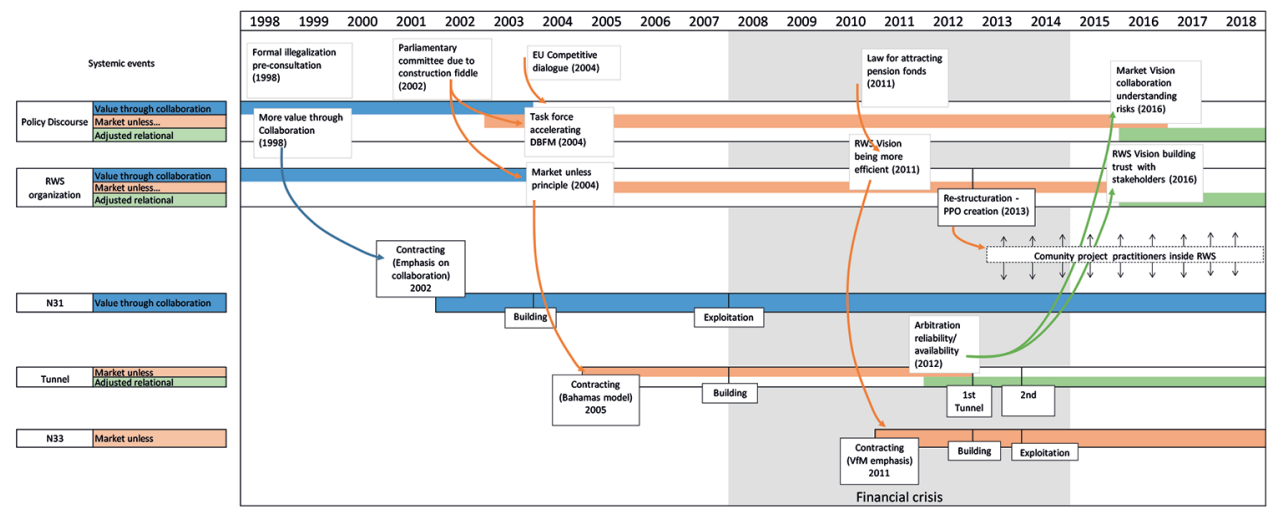

Figure 3.1 Relationing at the project, organizational and field levels

\subsubsection{Relationing Dynamics at Project, Organization and Field Levels}

First, in the N31 and N33 projects, public-private relationing embedded in the contractual arrangement remained the foundation of interaction reproduced by development morphogenetic and morphostatic cycles. In the case of the N31 project, the turn to market at field level in 2004 did not imply a fundamental transformation of the project practice upon the principle of more value through collaboration dating back to 1998. Likewise, the N33 project interactions emphasized economic efficiency and were not fundamentally altered by concerns for trust-building at field level in 2015. In the case of the tunnel, the initial conditions strongly relied on the principle of autonomy upon the idea that all risk could be transferred and assumed by the market. The arbitration led to a creative morphogenetic cycle at the project level, increasing the engagement of the public party in managerial coordination. This change of relationality at the project level occurred before the shift of relationality at the organizational and field levels. In summary, our observations indicate a pathdependence process, stemming from the relationality that characterized the field and organizational levels during the procurement phase. However, relationing at project level did not necessarily change as it happened at the field and organizational levels. When a fundamental change in the relationality at project level occurred, it did not happen at the same time that the alteration to relationing at the field and organizational levels.

\subsubsection{Organization and Field Levels Causing Relationing Change in Ongoing Projects}

Having established the diachronic dynamics at project levels in relation to organizational and field dynamics, it seems that governance structures within ongoing projects did not directly change as a result of changes at the organizational and field level. Particularly, the reproduction of relationing in the N31 and N33 projects emerged from conflicts resulting from decisions made in previous cycles of interaction at the project level. Most of the interaction at the project level led to developmental morphogenesis or morphostasis. Then, actors introduced changes triggered by exogenous events within the project governance structure blueprint. In the case of the tunnel, the change of project governance structure was predisposed by the contradiction between different levels of organizing 
mediated by choices made by people assuming project managerial roles. The emerging conflict from risk misallocation brought to light the latent tension between the autonomy principle and the strongly regulated project environment. The arbitration led to a pure morphogenetic cycle at the project level, increasing the engagement of the public party in managerial coordination. Within this new blueprint of relationality, further developmental morphogenetic cycles adapted the contractual forms to the operative context.

Hence, project dynamics were by no means isolated from the changing relationing configuration at the field and organizational levels. At the moment of collecting data, project managers expressed as desirable to re-negotiate coordination when dealing with conflicts between project and organizational demands. For example, the public project manager in charge of N31 and N33 recalled as legitimated the re-valorization of the Dutch tradition to guide public-private interactions. According to him, the Dutch tradition focuses on building and agreement to solve problems rather than discussing the discrete contractual responsibilities, contrasting to the Anglo-Saxon which focuses on defining "this is your responsibility, this is my responsibility". This re-valorization of Dutch tradition was aligned with the Market and HA strategic vision defined in 2016. However, the possibility to materialize in practice the expectation of close coordination was constrained to the relationing defined by the initial procurement conditions contractually sanctioned at the project level.

\subsubsection{Ongoing Projects as Mechanisms of Change at Organizational and Field Levels}

On the other hand, change of governance structures at the organizational and the field level was informed by governing activities and events at the project level. Once again, the tunnel turned to a be paradigmatic case. The conflict emerging due to "reliability" vs "availability" or "Bahamas attitude" seems to have a decisive impact on the re-valorization of relational aspects, along with the postcrisis economic context. Likewise, the informants referred to the A15 project, another example of the conflict due to transferring the risk of acquiring permits to the contractor, who was eager to assume high risks for getting the contract awarded. In both cases, the DBFM contracting operated under the public expectation that the private sector "knows better". The AH assumption was that competing contractors were aware of the risk they were assuming, while the private companies expected more collaboration from the HA to pressure stakeholders for the permits. When it became evident that private parties were not able to fully take responsibility for stakeholder management, contractors required more collaboration from the HA to pressure stakeholders for the permits. The lessons learned from these two projects allowed the unit in charge of defining procurement procedures inside the HA (Inkoopcentrum Grond-Weg- en Waterbouw - ICG) to modernize the criteria of risk allocation for other projects. One of the officers of the ICG explicitly explained that current DBFM contracting is more sensible to RWS responsibilities in terms of "supporting" the contractor when dealing with powerful stakeholders, even when stakeholder management activities are still transferred in DBFM contracting. The Cohen tunnel and the A15 projects were critical experiences that pushed decision-makers inside the HA and the Infrastructure Ministry and other key players at the field level to change the vision of the market in 2016. 


\subsubsection{Project Managers as a Group with Vested Interest at the Project, Organizational, and Field Levels}

Public project managers created a community of practices for improving their position of control and autonomy at the project, organizational, and field levels. The emergence of this community of practices illustrates how structural changes are mediated by the creative capacity of people for building new relations and pushing forward their positions. Looking back to the early 2010s, the community emerged from the alternation of vested interest inside the HA. The shift of autonomy and control relations at field level enabling DBFM was coupled with a reorganization process within HA under the logic of "market unless..."(2004). In particular, the introduction of "client perspective for more efficiency" in the HA in 2011 led to the creation of PPO in 2013. From then on, the GPO has been in charge of managing the realization phase of DBFM contracts and the PPO the exploitation phase. However, the PPO group identified themselves as rather "weak" in comparison to the well-established GPO. In the words of a project manager, the "GPO group had the power in the past. And they were directing the entire process, and they directed the maintenance phase as well". Furthermore, the maintenance activity was regarded as "not very sexy", "low value" and "repetitive". In this context, the PPO project manager of the Coen Tunnel purposively avoided to take over the contract from the GPO until he was able to develop the capacities to understand and assume maintenance responsibilities. Instead, the project managers of the tunnel project and the N31/N33 projects gathered together in a learning environment to get more knowledge about DBFM. This informal regrouping was a key element of the growing power of maintenance people, enabling them to selectively decline responsibilities "that the building group GPO would try to deliver". In other words, the initial phase of the community of practice triggered a process of balancing powers inside the HA, leading to "some tensions" between the PPO and GPO.

In the second phase of the community, the PPO managers leading the community concluded that "a lot of knowledge has to be gained in the building phase, or it has to be transferred from the building phase". Furthermore, there was a vested interest in counterbalancing the increasing deterioration of public managerial control in Dutch civil works shared by PPO and GPO. The manager explained that "the organization has taken some distance from the work floor. There are so many contracts. At the end we are responsible, and we make a lot of paper between us and the office towers, and the guys working on the floor, and we lack the contact with the floor". Therefore, the community of practitioners redefined the scope of its activities by increasingly engaging GPO members in their activities. One public project manager indicated that the community of practice "has a nice mix" of members operating "more or less as a whole, but not as separated departments" after building more connections with GPO colleagues. In other words, the initial meaning of the relationing around the community of practice changed from balancing power within HA to a collaborative space for building working relations within the HA. And consequently, the community was a vehicle to strengthen the position of public project managers in relation to private managers at the project level and introduce change at the field level.

At the project level, the community of practice allowed public project managers to increase consistency across different projects with private contractors. In this regard, the novice contract of the N33 explained that by attending to the community of practice she was able to align the criteria for assessing the suggestion of the contractor to deploy extra-maintenance of the road due to the (unexpected) deterioration of the road. As the contractor for two different projects was the same 
company, "if I tell him I don't want you to do anything, and the other [public project manager in another project] says to the contractor fix it, and we have money, then HA has a problem". On the other hand, the community of practice engaged in a collaborative interchange with the unit in charge of defining procurement procedures inside the HA (Inkoopcentrum Grond- Weg- en Waterbouw - ICG). Project managers and ICG shared the mutual interest in gaining knowledge from each other to implement and adapt the DBFM regime. ICG support was key to the growing and development of the community of practitioners. According to one public project manager, they were "the oil in the community, they [the ICG] could help us with facts and figures, they helped us with instructions". Likewise, "they were also very interested in our practices and examples that we met upon during operations, and our contact with contractors". This informal exchange supported the learning process for adapting the DBFM procurement process, as well as the ideological legitimization to shift back to the collaborative policy discourse from 2016.

\subsection{DISCUSSION}

The idea of mutual constitution borrowed from structuration theory made explicit the embeddedness of temporary organizing co-evolving with more permanent organizations, fields, and networks (Grabher, 2004; Sydow et al., 2004). However, framing temporary and permanent organizing as mutually constituted limited our understanding of this interface (Bakker et al., 2016). Temporary organizing scholarship has mainly stated in a rather axiomatic way that temporary and permanent interface is dynamic in a recursive relation. By using the lenses of analytical dualism, this research disentangles the recursive relation as an emergence process or interplay between temporarily and permanent organizing. These levels of social organizing are defined as existentially dependent but essentially different due to the emerging structural properties materialized in governance structures (Reed, 1997). Accordingly, there are three main insights for the understanding of the interface between temporary and permanent in the governance of projects that structuration theory omits: first, that temporarily and permanent organizing operates at different strata of social organizing; second, the articulation of positions, vested interests and relations to practices; and third, the existence of morphogenetic times beyond objective and subjective times. By revealing these three insights we can theoretically explain why temporarily organizing dynamics can be perceived as relatively autonomous to field and organizational changes (Brookes et al., 2017; South et al., 2018), without losing sight of its open nature to the contextual environment and historical conditioning (Engwall, 2003; Van den Ende \& Van Marrewijk, 2019).

\subsubsection{Permanent and Temporarily Organizing as Different Strata of Social Organizing}

The notion of planned isolation advanced in early temporary organization theory provided the insight that front-end governance structures are meant to counteract disturbances (Lundin \& Söderholm, 1995). Since then, literature deriving from structuration theory has consistently shown how the execution of temporary-bound agreements are open to contingency, creativity, and change (Engwall, 2003; Sanderson, 2012). By endorsing the underlying ontology of practices in structuration theory, 
temporary organizing literature previously argued that permanent and temporary coupling and decoupling is the outcome of actors playing with the meaning of permanent structures by practice (Bresnen et al., 2004; Sydow et al., 2004). This framework can, therefore, account for some observations in our research such as conflicting events due to projects open to contingency (N33) as well as actors' capacity to enact contractual bonds with some degree of subjectivity (N31). Nevertheless, structuration framework cannot theoretically explain the emergence of conflicts due to the latent contradiction between the embedded relationing in governance structures and the logic of operations of wider contexts (Tunnel case). This empirical insight studying Dutch PPPs made the point that there are organizational structures in contradiction, which are external to individuals assuming roles. Therefore, actors in the present are predisposed to engage in conflictive, concessional or collaborative modes of interaction irrespectively of existing actors' interpretations and wills. Giddens - and their followers studying temporary organizing - deny this externality by reducing structures to memory traces in individuals (Hampel, Lawrence, \& Tracey, 2017). The conflation between agency and structure in an ontology of practices has been recently reproduced by articulating structuration perspective and institutional work in accounting for the interaction between projects, organizations and institutions (Söderlund \& Sydow, 2019).

Only conceptualizing that structures are external to the agency is possible to fully embrace the common view that conflicts faced by actors emerge from the multilayer structure of temporary and permanent organizing (Söderlund \& Borg, 2018; Sydow \& Braun, 2017). Critical realist tradition provides the idea of emergence to characterize temporary and permanent as different levels of organizing with structural properties by their own right. In our research, the morphogenetic cycles at project level emerged from the intentional agreement between (organizational) actors, previously unrelated but situated in a field governed by relations of autonomy and control. Contracts - as the temporary governance structures - reflected the historical configuration of autonomy and control relationing in the different waves of PPP adaptation in the Netherlands (Koppenjan \& de Jong, 2018). In other words, the organization of PPP projects relied on the doings and forms considered legitimate for the time being at the field level (Söderlund \& Sydow, 2019; Swärd, 2016; Windeler \& Sydow, 2001). The time-bound agreement turned this historical relationality in an internal structure of position between previously unrelated actors, acquiring new powers and demands by virtue of their temporary relation materialized in a contract (Fleetwood, 2008). Nevertheless, our results suggested that practices inside ongoing projects did not co-evolve in the same direction and rhythm with the field change as the idea of mutual constitution necessarily implies (Manning, 2008). This diachronic dynamic indicates the benefits of embracing an analytical dualist perspective in temporary organizing.

The analytical dualism for temporary organizing implies that time-bounded agreements lead to a temporary organizing system. This system operates in a stratum that emerges, but is not reducible to the permanent organizing dynamics where the time-bounded agreement took place. The dynamics of a temporary organizing system takes a different path than the dynamics of a permanent system by virtue of actors reproducing and changing the initial time-bounded agreement. Emergence does not imply the reification of the project governance towards optimization, nor can temporary structures be decoupled from its contextual environment. (Blomquist \& Packendorff, 1998; Grabher, 2002). Actually, the temporary organizing system is regarded as open in their structural conditions (permeable) but also in their empirical manifestation and outcomes (non-predictable) (Fleetwood, 2017). That is why 
actors face multiple demands as they take a position in relation to different layers of human organizing, with the capacity to define priorities, introduce creative and change. The emergence and open nature of temporary organizing systems allow us to explain why temporary organizing dynamics acquire relative autonomy, even when they are part of the arrayed configuration of social organizing related to upwards and downwards causation.

\subsubsection{Articulation of Positions, Vested Interests and Relations to Practices}

We acknowledge that existing literature in temporary organizing already suggested that organizing practices change as an emergent result of alterations in positions and relations of control and autonomy. The seminal work of Windeler and Sydow (2001) explicitly referred to the increasing autonomy of private organizations as the background where the project network emerged as a new governance form of the German TV industry. In another research context, Bresnen et al. (2004) explored how project actors re-embed new knowledge during the implementation of top-down organizational innovations. They identified a project leader resisting the top-down innovation by virtue of his relative autonomy. Recently, Lieftink et al. (2019) suggested that the results of relational work for introducing new temporary organizing practices are constrained by the social position of the organization in the field. What we point out is that their ontological grounds limited them to explicitly articulate such as kind of empirical insights into a consistent theoretical framework or temporary organizing. In comparison to Windeler and Sydow (2001), our approach focuses on how relationing as the structural configuration of positions at the field level enables a higher or lower level of autonomy to private parties in PPPs. It is by virtue of that structured relation that actors within the partnership enact governing activity with higher or lower levels or close coordination. In contrast to Bresnen et al. (2004), we define autonomy as a structural property of the temporary organizing explicitly rather than a barrier for learning. Therefore, we make salient the existence of working positions meant to be temporary but with own performative demands to those who assume these roles (e.g. project management). Finally, we claim that relational work cannot be reduced to a strategy for building legitimacy around a new organizing practice as Lieftink et al. (2019) argue. We place building relations as the centre of temporary organizing dynamics. Hence, contesting and re-creating existing structural relations shape the path of temporarily and permanent organizing, and therefore their governing practices.

Our observations of project managerial agency illustrate this point at the level of temporary and permanent organizing. Previously, Benitez-Avila et al. (2019) indicated that actors with vested interested at the project level are able to reflect, regroup and size on the opportunities to improve their relative autonomy and control position within the temporary organizing. Their reflexivity operated under the basis of their dual position, aiming to creatively conceal their vested interest for pushing forward the project while attending the demands of their parent organization levels. Our results further elaborate the argument made by Benitez-Avila et al. (2019), pointing out that the driver of morphogenetic cycles was the innovative ways that people enacted contractual obligations and re-created initials objective grounds of relationing. In the N31 and tunnel cases, managers built a working relationship not reduced to contractual exchanges. This creative enactment of contractual relations opens a space for altering the configuration of control and autonomy relations embedded in contractual forms. The emergent agreements altering project governance structure were defended at the parent organizational level by public project managers. Yet, the capacity to re-create relations at the project level can be inhibited 
as the N33 indicates, as the track of interaction provided primacy to the belongingness to the parent organization. When the novice manager reacts in a sceptical way to the team-building session with the private counterpart, her reaction brings to light that appropriating collaborative practices are emergent to an articulation of "we" identity.

Our results suggest that the struggle for improving relative autonomy and control can be better appreciated by looking at the role of project managers as players taking a stake in permanent organizing. What is particularly insightful is the role of the community of practitioners emerging as a collective relational subject (Donati \& Archer, 2015). Public project managers in charge of the maintenance phase recognized themselves as actors with vested positions inside the HA, regrouping in the community to improve their relative autonomy and control position in relation to the building group. In other words, the community of practitioners was an alliance to attend concerns of expert power inside the organization (Reed, 2001), as an emergent resultant of the HA formal re-organization aligned with the relationing favouring a turn towards the market at field level. Subsequently, the community as such transformed itself as a collective relational subject by shifting the ratio prima of their relation inside the HA. The inclusion of other sub-units inside the HA defined the concerns of expert powers in relation to the private counterparts in PPPs projects. By imagining innovative ways of professional and collaborative relationing, managers developed the capacity to influence (or at least inform) higherlevel initiatives for changing policy and control and autonomy relations at field level. In our case, these are the efforts for moderating the implementation of market-oriented relationing embodied in DBFM contracting (Koppenjan \& de Jong, 2018). While temporary organizing has pointed out that projects are embedded in informal epistemic communities (Grabher, 2004), our research frames sharing knowledge in emerging epistemic communities as a practice subrogated to the struggle defined by vested interest. Much attention has been received the idea of projects as vehicles of change (Lieftink et al., 2019; Söderlund \& Sydow, 2019; Tukiainen \& Granqvist, 2016). Taking as empirical context the changing field of PPPs in the Netherlands, change necessary entails the articulation of the "we" identity of professional groups and their position at project level, organizational and field levels.

\subsubsection{Morphogenetic Times Beyond Objective and Subjective Times}

Engineering and economist approaches to organizational studies typically characterized time as a limited resource and measured in terms of length (Orlikowski \& Yates, 2002). The co-evolutionary perspective characterizes time beyond their objective properties, framing temporary organizing dynamics as driven by the interpretative shifts that actors attribute to the permanent and temporal (Granqvist \& Gustafsson, 2016). Co-evolution can well capture temporality of short-term projects operating as instruments at hand of actors being able to reflect on taking-for-granted norms and progressively re-shape them at the contextual field and deliberatively changing institutional logics (Tukiainen \& Granqvist, 2016; Windeler \& Sydow, 2001). But as long-term temporary organizing acquires emergent structural properties, actors within the temporary organizing system are constrained to play with the meaning of temporary governance structure. As already discussed, the change at field level requires a process mediated by the reconfiguration of relations of autonomy and control between actors beyond the simple manipulation of meanings. Additionally, our research made the point that actors are exposed to changing structures of relations at field level whose properties in the present are only activity-dependent in the past. This is the case of the recent re-valorization of the Dutch tradition 
of close coordination, which could not be directly introduced to the dynamics of N33 project due their path dependence.

It has already been remarked that empirical research in temporary organizing naturalizes the short temporality of projects (Brookes et al., 2017), regardless that institutional termination rather than short-length is what defines temporary organizing (Bakker et al., 2016). We add that the roots of this naturalization can be tracked in the co-evolutionary perspective that overestimates the possibility to play and negotiate structures of meaning and legitimization. Therefore, along with objective and subjective time, our research brings forward the idea of morphogenetic understanding of time in temporary organizing. We define the morphogenetic understanding of time as the framework that focuses on cycles of change and reproduction of structural properties by virtue of governing activity. This means that there is a historical process where the existence of structures of temporal organizing operates in the past, and they are not at the will of agents' interpretations in the present.

\subsection{CONCLUSION}

This research used as empirical setting the changing field of PPP in the Netherlands for clarifying the temporally and permeant organizing interface. By examining the extent to which temporary organizing structures change or remain stable due to governing activity within PPP projects, our results pointed out the embeddedness but also the relative autonomy of temporally organizing once its governance structure is formalized. We argue that the underlying ontology of practices in structuration theory cannot capture the emergent structural properties of temporary organizing, as it does not provide ontological substance to structures beyond peoples' instantiations. As alternative, we introduce the perspective of analytical dualism and the morphogenetic approach. By doing so, we frame events modifying the inter-organizational governance structure of temporary agreements as a part of a sui generis morphogenetic cycle. There, managers and teams take the role of agents/actors, which in turn emerges but is not irreducible to morphogenetic cycles operating at field level where organizations take the role of agents/actors. By stepping aside from Giddens's ontology of practices, our research provides an alternative view for studying temporary organizing as process and perspective.

Temporary organizing scholars should conceptualize the nature of temporary and permanent as the interplay of their structural emerging properties over time. Agents are able to shape the path of temporary organizing by the creative enactment of the initial conditions of the initial agreement, which nevertheless embodies the configuration of control and autonomy of structural relations for the time being. On the one hand, temporary organizing acquires a relative autonomy. On the other hand, the inherent contradictions between the embedded relationing of the initial agreement with respect to the context of operations open the possibility of change. Actors with vested interested at the project level are able to reflect, regroup and seize the opportunities to improve their relative autonomy and control position in their parent organizations and at the field level. In practical terms, our insights provide clearer grounds for understanding resistance in temporary organizing. The resistance is given by the structural predisposition shaping vested interests for changing and reproducing existing forms 
or organization. Therefore, practitioners should first consider the vested interest emerging from the temporary bounded agreement as objective predispositions to address in organizational change.

This article has a number of theoretical limitations that open new opportunities for discussion and research. First, we pointed out that morphogenetic time requires to be considered along subjective and objective time in temporary organizing (Bakker et al., 2016). Yet, the definition of specific properties of time in terms of tempo, rhythm and timing is a pending task within the lenses of the morphogenetic approach. Additionally, this article only marginally addresses the consequences of conflation in temporary organizing due to the articulation of structuration argument with institutional work literature (Lawrence, Suddaby, \& Leca, 2009; Söderlund \& Sydow, 2019; Tukiainen \& Granqvist, 2016). Further research can discuss the position of analytical dualism in relation to the catch-all "institution" concept which includes "pattern of doings", along with structural regulations, norms, beliefs and habits (Alvesson \& Spicer, 2019; Fleetwood, 2008; Mutch, 2018a). Likewise, further research can address the discussion between realist ontology and becoming ontology, whose center of discussion is the extent to which the former leads to essentialism and the latter to indeterminacy in studying temporary organizing (Böhm \& De Cock, 2005; Donati, 2017; Emirbayer, 1997; Mutch, Delbridge, \&Ventresca, 2006; O'Mahoney, 2012; Tsoukas \& Chia, 2002). There are also empirical limitations. The long-term nature of the observed projects implies difficulties to track the entire process, and their development would change in the future. On the other hand, our perspective focused on the perspective of the public organization in an organizational field strongly influenced by public policy. Therefore, further research is required to elaborate on the analytical dualism perspective on organizational fields with higher independence of public-private relationing. 


\title{
THE "3P CHALLENGE" - REFLECTING ON THE SENSE OF PARTNERSHIP IN PUBLIC-PRIVATE CONCESSIONS
}

\begin{abstract}
From a process management perspective, the key to successful Public-Private Partnerships (PPPs) is the legitimacy of decisions and outcomes along the project life cycle. However, the process management literature is sceptical about re-creating legitimacy and a sense of partnership in the implementation of concessional PPPs that rather resemble zero-sum games. To explore the possibility to re-create a sense of partnership in concessional PPPS, we developed the "3P challenge", a serious game for reflecting with practitioners on collaboration processes in the execution of concessional PPPs. Based on a multilevel conceptualization of project governance, the game offers a space for engaging collaboration to address project issues, but it also includes mechanisms that prevent players from making use of this space. The game played with a mixed group of practitioners and a team of public project managers showed that the game cycle activates reflexivity, making the point that PPP contracts can be creatively enacted with a higher or lower sense of subjectivity by managers who act as brokers of diverse interests and re-create a sense of partnership, clarity, and fairness of the PPP contract.
\end{abstract}

Keywords: Public-Private Partnerships - Process Management - Concessional Contracts - Serious Gaming - Reflexivity

\footnotetext{
${ }^{21}$ A working paper version was presented as: Benítez-Ávila, C., Hartmann, A. \& Dewulf, G (2019). The "3P Challenge" - Gaming and Reflecting on Partnership Meaning within Long-Term Infrastructure Contracts. $17^{\text {th }}$ Annual Engineering Project Organization Conference, June 25-27, Vail, Colorado (The United States of America)
} 


\subsection{INTRODUCTION}

The popularity of Public-Private Partnerships (PPPs) around the world paradoxically contrasts with their disputed assessments and fierce critics (Hodge \& Greve, 2017). Controversial outcomes exist regardless of the formal configuration of PPP organizational structures (Hodge et al., 2017), let alone their possible misfit with different institutional contexts (Matos-Castaño et al., 2014; South et al., 2018). In this regard, the managerial process engaged by actors seems to be the key to understand why PPPs work or do not work (Hodge et al., 2018; Klijn \& Koppenjan, 2016; Verweij et al., 2017). Satisfaction with project outcomes emerges from re-creating partnership legitimacy and stakeholders' support when dealing together with social and technical complexities (Klijn et al., 2007). This argument has been mainly brought forward for PPPs designed as alliances, where members share risks and rewards along the process of value co-creation (Kivleniece \& Quelin, 2012). Contracts are part of the partnership, but they do not become the partnership (Klijn et al., 2007). In contrast, concessional PPPs that transfer risks to private organizations by contractual agreements appear to become the grounds of project interactions (Kivleniece \& Quelin, 2012). According to the process management literature, concessional contracts shape zero-sum game situations and limit opportunities to re-create partnership meaning and legitimacy (Edelenbos \& Klijn, 2009; Klijn et al., 2007). However, there is increasing evidence that project managers attribute high value to collaborative relations in the process of implementing concessional PPPs contracts (Lenferink et al., 2013; Verweij et al., 2017; Warsen, Klijn, \& Koppenjan, 2019). What is less understood is the capacity of project managers to impute meaning and legitimacy to a concessional partnership concessional partnership. We are interested in the questions whether and to what extent it is possible for project managers to develop a sense of partnership in a concessional PPP.

The "3P Challenge" is a serious game to reflect with practitioners on the emergence of collaboration and the sense of partnership during the implementation of concessional PPP contracts. The game design follows the multi-level governance structure of temporal organizing from a positionedpractice perspective (Benitez-Avila et al., 2019), and its gaming cycle aims at activating participants' reflexivity (Donati, 2010; Donati \& Archer, 2015). Serious games are an alternative tool for researching and conveying key insights into performance management in public affairs (Douglas, Hood, Overmans, \& Scheepers, 2019). In this regard, they can play a dual role as research tools to capture insights from practice and as learning tools for practice. This study uses the "3P Challenge" game to gain insights into the enactment of PPP contractual relationships and at the same time to provide a space for practitioners to articulate concerns on PPP policy and implementation. Accordingly, the "3P Challenge" game simulates the tendering process of PPPs at the market level and its interaction with the implementation of the projects awarded. Situations are created in which public-private project teams have the mission of making the temporal partnership a success while capturing value for the parent organizations. The game includes the possibility to modify, adjust and even renegotiate initial agreements during the implementation phase to cope with uncertainty and eventual poor choices during the tendering phase. In the debriefing, players reflect on the gaming mechanisms favouring or hindering cooperation and compare them to their understanding of how governance mechanisms of PPPs operate in their working environment and policy context.

The "3P challenge" was played in two sessions with PPP practitioners in the Netherlands. The first session took place as an initiative to explore the introduction of service level contracts for the delivery 
of green infrastructure with a mixed group of professionals, including some PPP experts. The second session was a team-building activity between a group of PPP project managers. The gaming dynamics and the debriefing revealed that the mixed group of practitioners critically disregarded concessional PPP contracts as "real partnership" due to the operation of the penalty mechanisms. In contrast, the team of project managers clarified how the execution of penalty mechanisms could be used to build a reliable working relationship. We discuss these results in the light of processes management for the implementation of concessional PPPs and the creative enactment of the contractual relationship between managers recreating a sense of clarity and contractual fairness.

\subsection{THEORETICAL BACKGROUND}

\subsubsection{Process Management of Public-Private Partnerships}

The term Public-Private Partnership usually refers to an enduring contractual relationship that brings together complementary public and private resources by sharing or allocating responsibilities and risks between contracting parts (Grimsey \& Lewis, 2005; Verweij et al., 2017). Formal arrangements aim at enabling the value co-creation process by addressing uncertainty and opportunistic behaviour, factors that jeopardize the capture of promised payoffs (Nooteboom, 1996; Williamson, 1981). Consequently, organizational scholarship studies the underlying logic of value creation and the desired level of private autonomy or collaboration with the public sector to deliver successful PPP projects (Kivleniece, 2013; Kivleniece \& Quelin, 2012). However, empirical assessments indicate that PPPs are not immune to traditional project conflicts due to risk misallocation (Hoezen, 2012), displaced-agency problems (Volker \& Hoezen, 2017) and role ambiguity (Anastasopoulos et al., 2014). In the light of disputed outcomes, the process management literature points out that organizational designs are necessary to structure PPP agreements, but they are insufficient to deliver successful projects. It is not the organizational form, but "it's the management, stupid!" (Klijn, 2008).

The reasons for success and failure lie in the multiple and often conflicting expectations around PPP projects (Hodge et al., 2017). PPP support cannot be taken for granted. While traditional project management aims at executing plans according to the front-end organizational arrangement (Lundin \& Söderholm, 1995), process management focuses on re-legitimizing and re-creating the partnership over time (Verweij et al., 2017). Sponsors continuously need to conceal different stakes, implying that contractual forms might have only a marginal impact for accounting why PPPs work (Klijn \& Koppenjan, 2016; Kort, Verweij, \& Klijn, 2016). Therefore, satisfactory outcomes are the result of deliberate attempts to guide interactions between different actors along the entire process of decision-making, realization and exploitation of PPPs (Edelenbos \& Klijn, 2009). Klijn et al. (2007) make a clear differentiation between alliance-type and concessional PPPs. An alliance PPP is an organizational cooperation method rather than a contractual arrangement. This sort of PPP combines substantive activities and projects for a sustainable financial case addressing the trade-offs between "profitable and less profitable but socially interesting components" (Klijn et al., 2007, p. 73). As value emerges from dealing with technical and social complexity (Kivleniece \& Quelin, 2012), project sponsors recurrently can seize trade-offs and contingent issues as opportunities to re-create partnership meaning by 
engaging in negotiation, dialogue and leadership. To sum up, the success of PPP alliances depends on good process management.

Concessional PPPs are different. This type of PPP bundles the entire life cycle in a contractual assignment commissioned to a Special Purpose Vehicle, which is also in charge of unlocking private financing. Concessional PPPs create value due to the optimization of capital and operational expenses leading to sustainable service and bankable projects. Value creation in concessional PPPs stems from the axiom that private organizations are more efficient in the delivery of public goods, but positive externalities lead to under-provision by the market (Rangan et al., 2006). The government must re-allocate costs to beneficiaries in order to compensate private organizations that have a higher capacity to introduce efficiencies in the delivery of public goods (Kivleniece \& Quelin, 2012). The successful development of concessional PPP markets depends on the proper arrangement of payment mechanisms as incentives for performance (Smith, Zhang, \& Zhu, 2004), even when it is expected that risk and rewards are subject to constant negotiation (Cui et al., 2018). The idea of partnership is reduced to the process by which public and private organizations come together to engage in a long-term contractual relationship, identifying who is the best one to deal with project risks. Once the formal agreement is in place, working relationships are mostly dependent on the accurate but discrete ex-ante allocation of contractual responsibilities (Koppenjan \& de Jong, 2018).

Bringing forward the logic of operation of concessional PPPs, Klijn et al. (2007) predicted that concessional PPPs constrain the opportunities for rebuilding the sense of partnership once the frontcontractual agreement has been closed. Contractual mechanisms structure a potential conflict between the imperative of collaboration to create value and the contractual distribution of value, enforceable by legal means (Klijn et al., 2007). The discrete allocation of obligations defines the interaction in the absence of "embedded social structures that legitimate and recreate the partnership form over time" (Klijn et al., 2007, p. 88). Parties are exposed to opportunism and the renegotiation of concessional PPPs due to the possibility that the counterpart takes advantage of the lock-in relationship (De Brux, 2010; Domingues \& Zlatkovic, 2015). From the perspective of process management, concessional PPPs do not substantially differ from an agent-principal relation due to the little space for collaboration and co-production during their implementation (Weihe, 2008).

However, recent empirical research points out that managers in charge of executing concessional PPPs consider a sense of working partnership as a factor of successful PPP projects (Lenferink et al., 2013; Verweij et al., 2017; Warsen et al., 2019). The operation of concessional PPP arrangements takes for granted that risks can be assessed at the front-end of contractual engagement, although practitioners identify higher levels of complexity and uncertainty (Lenferink et al., 2013). As a consequence, developing working relationships with some sense of collaboration and partnership can soften project difficulties, and also concessional PPP projects need to have a certain level of trust or conflict management practices (Warsen et al., 2019). What is not clear is how managers can overcome the incentives shaped by PPP concessions that prevent them from building a sense of partnership. The discrete ex-ante allocation of risk and rewards in concessional PPPs potentially pushes project managers to adopt autonomy-seeking solutions, even if they personally regard close collaboration as desirable (Verweij et al., 2017). 


\subsubsection{Dual Position of Project Managers}

The turn to social theory in project management literature has opened up new avenues for studying how managers engage in partnership arrangements and enact contractual relations that can trigger competitive interaction. Project managers face divergent demands by virtue of their dual role as part of the temporal partnerships and members of permanent parent organizations (DeFillippi \& Sydow, 2016). The dual position is intrinsic to the operation of temporary organizations emerging from permanent organizing, both operating in different strata of social organizing. Before contracting, parent organizations operate as unrelated entities that independently form each other in a field (Fleetwood, 2008). Hence, their relation is contingent (or external) in the sense that the organizational properties of one entity exist independently of the other organizational properties (Archer, 1995). Procurement and contracting processes lead to a fundamental transformation that binds parent organizations in a necessary but temporal relationship (Benitez-Avila et al., 2019). Then, entities once related acquire new powers and liabilities by virtue of the contractual relationship in which they engage. This relation is necessary (or internal), as the emerging temporal organization cannot be what it is without their constituents (contracting parties) (Archer, 1995). The dual position of project managers in PPPs implies that they are simultaneously related to the counterpart in a contingent relation (as members of parent organizations) and a necessary relation (as members of the temporal organization) (Benitez-Avila et al., 2019).

While the necessary relationship predisposed public and private project managers to engage in modes of interaction ranging from solidarity to compromise at the project level, the contingent nature of the relationship predisposes the same actors to engage in patterns of interaction ranging from opportunism to competence (Archer, 1995). In reference to these categories, the zero-sum game shaped by concessional PPPs operates upon the role of managers as agents of their parent organizations related to each other in contingent fashion. They have an objective demand to care for their organization stakes and compete for capturing value. However, they also are members of a temporal organization. From this standpoint, project managers depend on each other to fully perform as such. People filling project management positions can define a vested interest to maintain the very existence of the project itself, counselling differences and even defending the project from external disturbances.

Adversarial or collaborative interaction between people assuming project managerial roles are rooted in the objective demands of their dual position; insofar organizational and contractual relations are simultaneously enacted by these managers operating PPPs (Benitez-Avila et al., 2019; Reed, 2001; Tuominen \& Lehtonen, 2017). This means that objective demands and predispositions do not operate as mechanical pressures but are manifested in associative and dissociative relations that are enacted and recreated by human action (Donati \& Archer, 2015). Therefore, it can be expected that project managers reflect upon the dual objective predispositions (Caetano, 2015; Donati, 2016; Sanderson, 2012). Reflexivity is "the regular exercise of the mental ability, shared by all (normal) people, to consider themselves in relation to their (social) context and vice versa" (Archer, 2007, p. 44). In realist relational sociology, reflexivity is imperative when individuals are confronted with the necessity of selection (Donati \& Archer, 2015). Hence, reflexivity in governing PPPs refers to the managerial capacity of actors to assess, prioritize and balance competing demands due to their dual position at a project and parent 
organizational level (Benitez-Avila et al., 2019). Reflexivity allows them to creatively enact the embodied pattern of relations in contractual forms and PPP policy and build a sense of working relations that emerge from contractual obligations but are not reduced to their control mechanisms. It can be the case that managers place between brackets the discrete allocation of contractual responsibilities for engaging in close collaboration (Benitez-Avila et al., 2019).

\subsection{METHODOLOGICAL CONSIDERATIONS OF GAMING}

This study uses a serious game as an instrument for reflecting with practitioners on the sense of partnership emerging in the implementation of concessional PPPs contracts. Serious games provide playful experiences of real-world situations, meaningful in terms of learning, training and research (Harteveld, 2011), bringing together social and technical complexity (Mayer, 2009). For researching the delivery of public infrastructure, they typically make use of classical game theory and experimental behavioural economics (Altamirano \& de Jong, 2009) with the aim of testing (and predicting) how different contractual incentives lead to specific patterns of behaviour. These games resemble the controlled setting or closed system of experimental research to "safely" explore/learn how specific rules would shape collaborative/adversarial relations in reality (Altamirano, Herder, \& De Jong, 2008; Dzeng \& Wang, 2017; Nassar, 2003). However, from a critical realist perspective which we adopt here, "it is a condition of the intelligibility of experimental activity that in an experiment the experimenter is a causal agent of a sequence of events but not of the causal law which the sequence of events enables him to identify" (Bhaskar, 1997, p. 11). In other words, scholars relying on social experimentation run the risk of taking outcomes achievable in a closed environment as metaphors of human activity and organization that are inherently open to contingency and creativity (Archer, 2013). The value of a controlled research environment lies in the opportunity to reflect on deeper levels of reality that inspired the controlled research design for theorization and practice. In this regard, a game should aim at enabling experiences to reflect on the conceptualization that inspired the game design itself. By adopting this methodological stance of critical realism, the design of the "3P Challenge" game aims at triggering reflexibility by comparing PPP governance mechanisms operating in the closed system (game) and the open system (practice).

\subsection{THE “3P CHALLENGE” GAME}

\subsubsection{Design Specifications}

The design specifications of the game are based on the perspectives of process management in concessional PPPs (Klijn, 2008; Klijn et al., 2007) and multilevel project governance (Benitez-Avila et al., 2019). On the one hand, the game structures interaction according to the zero-sum frame highlighted by Klijn et al. (2007) and the assumption that value emerges from the higher organizational capabilities of private contractors (Kivleniece \& Quelin, 2012). Additionally, the game follows the assumption that the development of concessional PPP markets depends on the accurate arrangement of incentives 
for performance (Smith et al., 2004) and the expectation that risk and rewards can be renegotiated during the realization phase (Cui et al., 2018). On the other hand, the game forges a multilevel dynamic resembling the dual position of project managers as members of temporal and permanent organizations (Benitez-Avila et al., 2019). The game establishes an objective conflict between project managers as the result of their role as a member of parent organizations related to each other in a contingent way. It gives the opportunity to reflect on this conflict and the co-dependency of project managers at the project level.

The "3P challenge" game consists of several rounds of tendering invitations at the market level in that each round leads to the implementation of a winning contract at the project level. The projects tendered/awarded are Design-Build-Finance-Maintain (DBFM) projects, i.e. capital and maintenance investments defined by the firms upon service specifications. Therefore, there are two game levels (market and project levels) and three types of teams (road authority, firms and temporal project teams) (Figure 4.1). A head leads the road authority team, supported by (two) public project managers. Likewise, firm teams consist of a CEO supported by (two) project managers. The project teams are temporal, comprised of a public project manager and the private project manager of the firm that wins the tender.

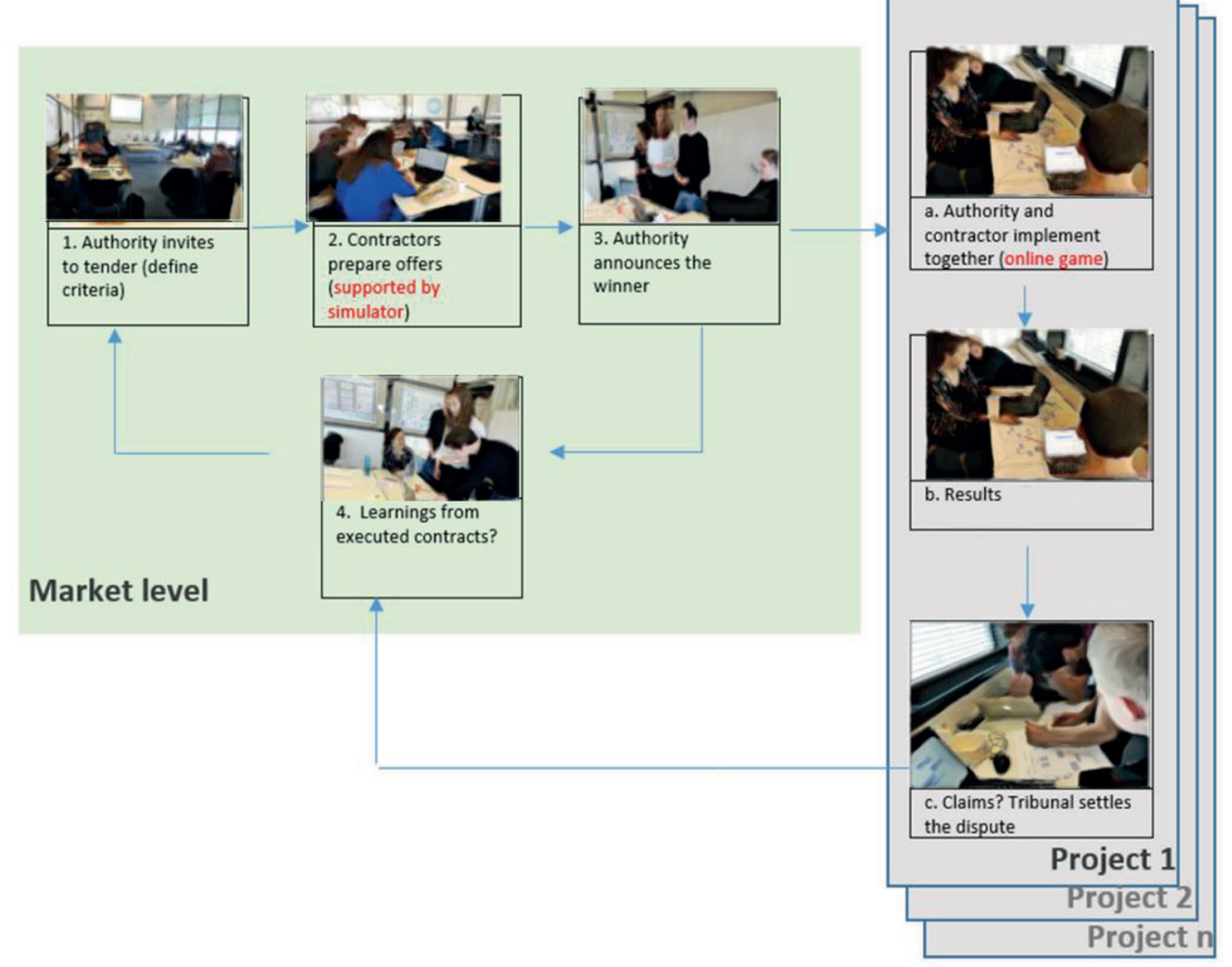

Figure 4.1 Game cycles at two levels: Market level and project level 


\subsubsection{Market Level Game}

The interaction at the market level is driven by competition and regulated by the road authority (Altamirano et al., 2008). The road authority invites to tender for a 20-year maintenance contract, exploring multiple types of contracting alternatives. The head of the authority can define the award criteria as fixed priced or lowest price, as well as penalties or bonuses upon service levels. Firms present offers, including the capital investment and a maintenance plan. The objective of the firms follows the logic of gain (maximizing profits), while the aim of public authority is maximizing the quality of the road (minimizing roughness measured by the $\mathrm{Q}$ index) ${ }^{22}$ and availability (minimizing interruptions for carrying out maintenance). The head of the authority and the CEOs have the last word in the decisions made at the market level. Firms use a systems dynamic simulation of the road deterioration for a 20-year lifespan, according to the Highway Design and Maintenance Standards Model (HDM-III) (Watanatada et al., 1987). The flight simulator has three areas: extra-capital investment, maintenance investment over time and key indicators to track road performance. Extra-capital investments can enhance strength coefficients (investing in the quality pavement) and layer thickness (investing in layer thickness) as well as predictability of the deterioration rate. Maintenance activities can be activated along the 20 years of the simulated project, having fixed and marginal costs depending on the deteriorated area. Key indicators include the visualization of the service variables (QI roughness index and non-availability - days closed per year for deploying maintenance activities), pavement quality (distress stocks), total cost (capital and maintenance costs) and a summary of the critical indicators over time. Firms can run different scenarios of initial investments and various combinations of heavy and low maintenance activities, estimating costs and trade-offs between service levels. The authority does not have access to the simulator to resemble the assumption that the market has developed unique capabilities to introduce efficiencies in the delivery and maintenance of public infrastructure.

\subsubsection{Project Level Game}

Once the head of the authority selects the winner, he/she appoints a public project manager for implementing the project with a private project manager appointed by the CEO of the winner firm. After signing a contract, the public and private manager implement the offer in an online game running year by year. The systems dynamic model that supports the online game randomly modifies parameters with high sensitivity. Players are not explicitly told so, but they are asked to bear in mind uncertainty. The public and private project manager controls different decisions (different screens and panel controls). The private project manager controls maintenance activities, while the public project manager controls penalties/rewards/extra payments. As players "run into the surprise" of sooner or faster deterioration, the online game provides the possibility to introduce modifications of the maintenance investments. Likewise, the simulator allows the public project manager to change his/ her strategy for imposing/waiving penalties and bonuses. Once the players run the online simulation for the 20 years, they share the final screen reporting the performance of the key indicators. Players are free to negotiate/re-negotiate the extra cost, taking into account that they need the authorization of their head/CEO. If there is no agreement, they can appeal to a tribunal (random card defining the winner), which settles the conflict. There is a facilitator at project level assuming the role of the Bank, collecting the expenses related to capital and maintenance investments. The bank also controls debt

${ }^{22} \mathrm{Ql}$ index measures the deviations of a surface from a true planar surface (Watanatada et al., 1987). Its range of values goes from 0 to 150. The increasing levels of pavement distress lead to higher deviation of surface and roughness (QI), leading to lower service quality for road users. 
settlements at the end of the project. The PPP winner team is the one who implements the project in the shortest time, with a positive project assessment of both managers.

\subsubsection{Game Session Arrangement}

The aim of a game session is to gain insights into the implementation of PPPs and practices by contrasting the gaming experience with the working experience of playing practitioners. Players are shortly briefed about the general game objective and the rules of the game in order to directly provide them with the game experience (Van Daalen, Schaffernicht, and Mayer (2014). During the gaming experience, the dynamics of the game is mainly determined by the public head authority at a market level setting level setting tender conditions. At project level public and private project managers can implement with more or less dialogue the outcomes of tendering rounds. The performance of implemented projects is captured through quantitative indicators from the simulation at the project level, and the qualitative assessment of project managers asked to answer whether the project was successful or not. At the end of each round project managers fill a closing report including scores and qualitative judgment of satisfaction. After the game session, participants were individually asked to respond which type of interaction best describes their exchange with other players - and why (e.g. competitive, opportunistic, solidarity and concessionary modes of interaction). Then, in a plenary session, the facilitator invites participants to compare the game experience with their practice. This includes questions about players' interactions with other players when activating game mechanisms (e.g. penalties) and how these interactions and outcomes of the game resemble the characteristics of working relationships and enactment of contractual obligations in practice. Table 4.1 summarizes theoretical design specifications and corresponding game characteristics.

Table 4.1 Theoretical design specifications and corresponding game characteristics

\section{Design specifications}

The game forges a multilevel dynamic resembling the dual position of project managers as members of temporal and permanent organizations (Benitez-Avila et al., 2019)

\section{Game characteristics}

(1.a) The game includes two levels: market and project.

(1.b) At the market level, the winning criterion is maximizing key values for public and private parent organizations (e.g. profit, quality of the road)

(1.c) At the project level, the winning criterion is implementing the project with mutual satisfaction

Structured interaction according to the zerosum frame highlighted by Klijn et al. (2007) for concessional PPPs (2.a) Structuring the game as a competitive market leading to a contractual relationship between selected contractor and authority

(2.b) During the project implementation, the private project manager is entitled to execute the initial offer or not to do so

(2.c) The public project manager is entitled to monitor the execution with financial rewards or penalties

The game reflects the assumption that value emerges from the higher organizational capabilities of private contractors (Kivleniece \& Quelin, 2012) (3.a) Private companies use a system dynamic simulator that allows them to calculate deterioration rate and costs

(3.b) Public authority does not use the simulator 
Design specifications

The game reflects the assumption that the successful development of concessional PPP markets depends on the accurate arrangement of incentives for performance (Smith et al., 2004)

The game reflects the expectation that risk and rewards can be renegotiated due to uncertainty during the realization phase (Cui et al., 2018)
Game characteristics

(4.a) Authority defines the tendering conditions, including penalties and rewards

(4.b) Market-level dynamics relies on the quality of tender specifications

(5.a) Support of gaming experience with two-system dynamic simulation

(5.b) The simulation used for preparing offers allows users to manage known risks

(5.c) Simulation at project level randomly modifies parameters leading to faster or sooner deterioration

The game makes the point that an objective conflict exists due to the dual managers' role as members of parent organizations related to each other in a contingent way

The game provides the opportunity to reflect on this conflict and project managers co-dependency at the project level (6.a) During debriefing discussion on the type of interaction engaged in the game and its comparison with professional practice

(6.b) Discussion on why players succeed or fail to collaborate at the project level

\subsubsection{Prototyping, Testing and Evaluation With Students}

This process took as reference the triadic model of serious gaming of Harteveld (2011), who assesses the quality of the game design as a balance between the three aspects of reality, meaning and play (Table 4.2). To balance them, the game was played in three preliminary sessions with Master and PhD students $(n=33)$. Students assessed the flight simulator as a realistic representation of the dynamics of road deterioration and maintenance studied in their courses and research. In a second validation stage, the final version was played with students of civil engineering at the Bachelor level $(n=13)$ and Master level $(n=9)$. It aimed at testing the questionnaire to capture the interaction of players during the game, as well as establishing a benchmark for setting the terms of the debriefing.

Gaming with students allowed us to corroborate that our game replicated the dynamics observed in similar games at the market level (Altamirano et al., 2008). Tender invitations based on lowest price lead to underestimation of costs by companies, who aim to win the call rather than structure a feasible project. Additionally, the head of the government usually struggled to define tendering conditions lacking information to assess the feasibility of their tendering requirements. At the project level, there was a tendency towards low interaction in the case of bachelor students. Bachelor students implemented the maintenance plan in a rather mechanical way without engaging in re-negotiation when the online-simulator led to unexpected project performance. There was a higher level of interaction in the case of Master and PhD students. Overall, players focused on winning the game as permanent organizations rather than winning at the project level as temporal teams.

According to the observers, three aspects might have led to the described dynamics at the project level. On the one hand, players easily related to the idea of being part of a permanent team competing or regulating the market. Therefore, building a sense of temporal team at project level was constrained by the strong identification of project managers as a part of a firm or the authority at the market level. 
Second, the facilitator stated that conditions of the implementation could change due to uncertainty. However, students playing the role of private project managers were surprised by the higher variance of the simulation at the project level. They were expecting to observe the same dynamics simulated by the flight simulators used to structure offers during the market phase. Third, a possible explanation for the observed interaction was the lack of experience. Difficulties in structuring feasible projects at the market level, prevalence on winning the competition rather than structuring viable projects, and uncertainty led to low performance and dissatisfaction at the project level.

Table 4.2 Final game design characteristics after the prototyping-testing-redesigning process

Game design aspects Game characteristics(expanded) ${ }^{23}$
$\begin{aligned} & \text { Reality: To what extent }- \text { It connects to the multilevel structure of } \\ & \text { does the game connect } \\ & \begin{array}{l}\text { to the social/physical } \\ \text { world? }\end{array} \\ & \text { of managers at the project level and } \\ & \text { - It connects to public infrastructure } \\ & \text { procurement in competitive markets } \\ & \text { and the introduction of service contracts } \\ & \text { (2.a.b.c). } \\ & \text { - It connects to the roles of public and } \\ & \text { private managers in DBFM (4.a.b). }\end{aligned}$

Game design aspects Game characteristics(expanded) ${ }^{23}$

(Purposive) limitations

- The dynamics of patch deterioration and maintenance alternatives were omitted.

- It does not include the logic of competitive dialogue for the tendering process

- It does not include the role of banks in financing in DBFM contracting.

- The length of service contracts is reduced from 30 to 20 years.

- It does not consider re-work and unforeseen circumstances for the building phase.

\begin{tabular}{|c|c|c|}
\hline $\begin{array}{l}\text { Meaning: To what } \\
\text { extent does the game } \\
\text { have a meaningful } \\
\text { effect beyond the } \\
\text { gaming experience } \\
\text { itself? }\end{array}$ & $\begin{array}{l}\text { For the players } \\
\text { _ Experiencing the effect of (poorly } \\
\text { informed) tendering conditions on public } \\
\text { markets (5.a.b). } \\
\text { - Experiencing the effect of unforeseen } \\
\text { situations in managerial decisions at the } \\
\text { project level (5.c). } \\
\text { - It provides a venue for discussing the } \\
\text { possibility to engage collaboration in } \\
\text { concessional PpPs (6.a.b). }\end{array}$ & $\begin{array}{l}\text { - It does not aim to directly transfer } \\
\text { outcomes to principles of policy design } \\
\text { - It does not allow to understand how } \\
\text { pavement behaviour emerges from the } \\
\text { structure of the simulation. } \\
\text { - Not all players have the same gaming } \\
\text { experience (e.g. some firms might not win } \\
\text { a tender, and the road authority does not } \\
\text { use the flight simulator). }\end{array}$ \\
\hline $\begin{array}{l}\text { Play: To what extent } \\
\text { does the game have } \\
\text { engaging goals and } \\
\text { rules? }\end{array}$ & $\begin{array}{l}\text { - It includes permanent and contingent } \\
\text { teams with clear roles and gaming } \\
\text { objectives (1.a.b.c). } \\
\text { - It is based on the flight simulator and } \\
\text { online gaming (3.a.b; 5a.b.c). } \\
\text { - The dynamics of the game is engaging. }\end{array}$ & $\begin{array}{l}\text { - The simulation-based elements (flight } \\
\text { simulator and online gaming) implies a } \\
\text { considerable cognitive load. } \\
\text { - It requires a large number of participants } \\
\text { (12), and considerable time for playing } \\
\text { (+3 hours). }\end{array}$ \\
\hline
\end{tabular}

In conclusion, the 3P challenge offered a space for collaboration on the project level but also activated mechanisms preventing players from making use of this space. The gaming experience emulated the zero-sum game identified by process management in concessional PPPs and predisposed conflicts. However, we were concerned about the extent to which a conflictive gaming experience would be perceived as valuable for practitioners. The adversarial gaming experience had to be transferred into a "meaningful conflict" (Mitgutsch, Schirra, \& Verrilli, 2013, p. 720). A meaningful conflict encourages

${ }^{23}$ In brakets the characteristics derived from design specifications in Table 4.1 
players to engage a more critical play after some gaming rounds. Given time limitations, we focused on turning eventual adversarial gaming experiences into meaningful conflicts during the game debriefing. For doing so, the gaming experience was framed in terms of a "challenge" under the label of "partnership", bringing forward that the structure of relations in the game predisposes conflicts regardless of the PPP label. Debriefing questions aimed to (i) identify in which circumstances players were able to deviate from conflict predisposition (ii) compare the adversarial structure of the game with the roots of eventual conflict in concessional PPPs in practice and (iii) explore whether and how practitioners overcome the objective predispositions to adversarial interaction in practice. Table 4.2 summarizes the game design characteristics after the prototyping-testing-redesigning process. Notice that the game characteristics in Table 4.2 expand those formulated at the beginning of the prototyping process, previously summarized as characteristics meeting design requirements in Table 4.1.

\subsubsection{Game Sessions With Practitioners}

The game was played with practitioners in two sessions. The first session was arranged as part of an applied research activity led by an organization interested in exploring service contracting for the delivery of green infrastructure. The session brought together a group of mixed practitioners $(n=10)$ including eco-engineers and professionals with expertise in DBFM(O) projects in the Netherlands, such as private consultants and public procurement officers. The second session was arranged as a team-building activity for $\mathrm{DBFM}(\mathrm{O})$ public project managers $(n=10)$, with the particularity that the team head and other members were recently appointed to their positions. Therefore, the game was an opportunity for sharing knowledge between experienced practitioners and newcomers.

\subsection{RESULTS}

\subsubsection{First Game Session - Market/Project Level Outcomes}

The game session included five rounds of tendering invitations and corresponding projects. There were three firms competing. At the market level, the observations indicated that the head authority discussed the terms of the tenders with the respective public project managers, and one project manager, in particular, consulted the head for making decisions at the project level. The experience at the project level was shared by the project managers with the head of the authority. At the project level, the interactions were rather contingent on the project managers. Table 4.3 summarizes the performance of key indicators of the game, including the qualitative assessment of satisfaction by project managers at the end of the game. 


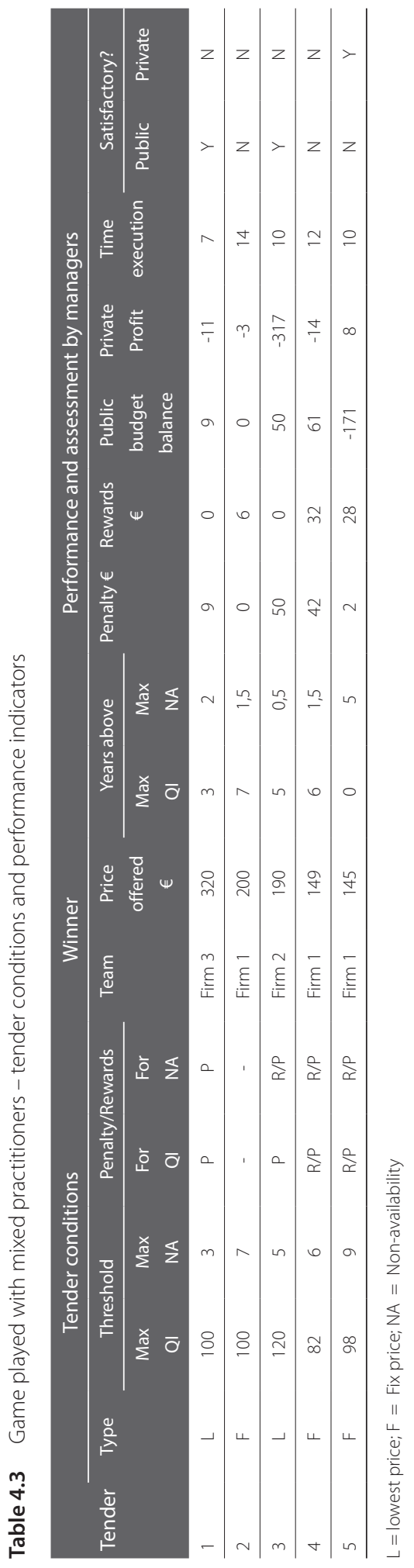


Game indicators and observations suggest the activation of the game mechanism, preventing satisfying project performance. There was no case where both managers regarded the game as satisfactory. Even the announcement that winning the game includes the "best PPP team at project level", the participants did not feel they belonged to a "team" at the project level. The reasons preventing team identification at project level included the physical gaming arrangement and gaming cycle itself. For example, during the implementation phase, the laptops were arranged in a way that did not allow players to see each other's screen, thus evoking an experience of competition. Furthermore, the players assuming the role of project managers worked together with the head of the parent organization in the market round, which acted as a barrier for the development of a team identity during the implementation of the project. In general, participants expressed that they did not feel compelled to consider other stakes because the tendering rounds were not set up as "partnership", but as a regular agent-principal relationship. In this regard, each party was very focused on his/her own objectives, in a situation where the firms experienced low-profit margins and high risk. For example, the head of the authority explained that he was, first of all, focused on avoiding budgetary overruns: "I was busy with my targets, and I didn't take into consideration other parties". He took for granted that the available budget could be divided equally for all projects based on the perception that firms were doing fine.

However, there was a difference in the way that practitioners made use of gaming mechanisms. In the first and third round, the public project manager was an experienced DBFM consultant. In the debriefing, he explained that his positive assessment considered the constraints and struggles for performing. He waived some penalties to alleviate budget pressure for the counterpart. The satisfactory outcome for the private firm in the fifth round was the result of overestimating rewards for good performance by the head of the authority. On the other hand, firms found that the tendering conditions were too demanding , leading to "not marketable" calls. Once these projects were awarded, players assuming the role of private firms aimed to minimize losses. For example, one project manager explained that he had to keep losses low given that initial estimations did not match the actual implementation of the project. He focused on keeping losses controlled and could not make sense of the unpredictability because the instructions did not explicitly point to the higher uncertainties in the project simulation. He was not able to explain the situation of the counterpart, nor could he consider the other's stake due to his struggle with his own performance. The incapacity to explain this difficult situation plus the decision to keep control of losses were interpreted as a deceptive attitude by the public project manager.

The game allowed the implementation of the contractual mechanism without and with communication. Retrospectively, the head of the authority asserted that he could have communicated better and could even have carried out a market consultation. In this regard, he indicated that the value of the game experience is the possibility to critically reflect on the tendency to take others' expectations for granted during the tender phase and contract implementation. He stated that "the game makes the point that you can implement the contractual mechanism without much communication, or communicate with the other party about what you have to implement". Table 4.4 summarizes the interaction assessment in the game session with mixed practitioners. 
Table 4.4 Interaction assessment - game session with mixed practitioners

\begin{tabular}{|c|c|c|}
\hline Relation & Role & Reflection \\
\hline \multirow[t]{4}{*}{$\begin{array}{l}\text { Authority } \\
\text { head and } \\
\text { CEOs (Market } \\
\text { mediated) }\end{array}$} & $\begin{array}{l}\text { Authority } \\
\text { head }\end{array}$ & $\begin{array}{l}\text { "As head of the authority, I had no knowledge or considerations of other parties. } \\
\text { And I had no interaction with other parties, except in the tendering. My concern } \\
\text { was merely meeting my target and setting parameters to stay within the financial } \\
\text { bandwidth." }\end{array}$ \\
\hline & \multirow[t]{3}{*}{ CEOs } & "We tried to maximize the profit of our company." \\
\hline & & $\begin{array}{l}\text { "We decided not to do any maintenance and accept penalties; however, the } \\
\text { situation forced us to do maintenance. This ended in costing us a lot of money." }\end{array}$ \\
\hline & & $\begin{array}{l}\text { "At the end, we settled the difference, but only due to losses in the project. } \\
\text { Unfortunately, there was little interaction upfront (during tender or award phase) } \\
\text { with the authority. We did not invest in building a relationship." }\end{array}$ \\
\hline \multirow{2}{*}{$\begin{array}{l}\text { Authority } \\
\text { head and } \\
\text { project } \\
\text { managers } \\
\text { (Hierarchy) }\end{array}$} & $\begin{array}{l}\text { Authority } \\
\text { head }\end{array}$ & $\begin{array}{l}\text { "We were risk-focused: trying not to fail rather than maximizing value. We did not } \\
\text { have conflicts but aimed at helping each other, realizing our common goal. We } \\
\text { didn't have a clear goal of resolving conflicts." }\end{array}$ \\
\hline & $\begin{array}{l}\text { Public } \\
\text { project } \\
\text { managers }\end{array}$ & $\begin{array}{l}\text { "I always viewed us as one team, so we defined a strategy together and followed } \\
\text { through" }\end{array}$ \\
\hline \multirow{9}{*}{$\begin{array}{l}\text { CEOs and } \\
\text { project } \\
\text { managers } \\
\text { (Hierarchy) }\end{array}$} & \multirow[t]{3}{*}{ CEOS } & $\begin{array}{l}\text { "The decision to do maintenance helped in the satisfaction of the project. In } \\
\text { retrospect, we should have asked for more money for this action." }\end{array}$ \\
\hline & & $\begin{array}{l}\text { "Only when our strategically offered bid did not work out, we discussed the } \\
\text { overruns/ settlement. When starting the project, we should have had more time } \\
\text { to discuss how to run the project over the } 20 \text { years. Including the redefinition of } \\
\text { the maintenance when needed or even proactively." }\end{array}$ \\
\hline & & "We tried to maximize the profit of our company." \\
\hline & \multirow{6}{*}{$\begin{array}{l}\text { Private } \\
\text { project } \\
\text { managers }\end{array}$} & "We just took into account the deadlines. We worked as a team." \\
\hline & & $\begin{array}{l}\text { "We tried to maximize profit without looking at other factors. We did not look at } \\
\text { the implementation or satisfaction." }\end{array}$ \\
\hline & & $\begin{array}{l}\text { "We offered a too-low price, with no financial buffer for developing quality. } \\
\text { However, it was impossible to simulate a bid with a normal profit." }\end{array}$ \\
\hline & & $\begin{array}{l}\text { "We tried to not invest in quality and perform maintenance to keep QI and } \\
\text { accepting penalties. We were able to offer low prices, acceptable QI but } \\
\text { breaching the promised days closed." }\end{array}$ \\
\hline & & $\begin{array}{l}\text { "The time per round was too short of having conflicting interest internally. There } \\
\text { was no distinction between the role as CEO as a project manager; it was much } \\
\text { more teamwork." }\end{array}$ \\
\hline & & $\begin{array}{l}\text { "The CEO was only consulted when a budget overrun was unavoidable. I was } \\
\text { certainly a little late, but this was due to stress and information overload at the } \\
\text { time this occurred. The CEO was very helpful and supportive; no conflicts had to } \\
\text { be settled". }\end{array}$ \\
\hline
\end{tabular}




\begin{tabular}{|c|c|c|}
\hline Relation & Role & Reflection \\
\hline \multirow{5}{*}{$\begin{array}{l}\text { Public project } \\
\text { manager and } \\
\text { private project } \\
\text { manager } \\
\text { (Project) }\end{array}$} & \multirow{2}{*}{$\begin{array}{l}\text { Public } \\
\text { project } \\
\text { managers }\end{array}$} & $\begin{array}{l}\text { "There was no real interaction. The respective plans were executed, and the } \\
\text { lessons learned went on to feedback into the next tender round." }\end{array}$ \\
\hline & & "We performed differently according to the situation." \\
\hline & \multirow[t]{3}{*}{$\begin{array}{l}\text { Private } \\
\text { project } \\
\text { manager }\end{array}$} & $\begin{array}{l}\text { "I experienced two interactions/games. In one, there was discussion interaction, } \\
\text { and it was interesting to see that the public contractor did not want me to end } \\
\text { up with a loss. In the other one, there was no discussion/ interaction." }\end{array}$ \\
\hline & & $\begin{array}{l}\text { Our strategy (firm) was to accept the penalties and not do maintenance. Of } \\
\text { course, this led to a low-quality road (bad for the authority). [Initially] we did not } \\
\text { change our strategy, because we believed that would not be possible for this low } \\
\text { price. When the authority started to raise the penalties, we negotiated and chose } \\
\text { one big maintenance and compensation from authority. }\end{array}$ \\
\hline & & $\begin{array}{l}\text { We had a conflicting interest, but we were able to settle these and look for } \\
\text { mutual benefits. The penalties given were reasonable and sometimes even on } \\
\text { the light side, this was due to the cordial relationship }\end{array}$ \\
\hline
\end{tabular}

\subsubsection{First Game Session - Reflection on PPP Practice}

During the game debriefing, practitioners regarded the interaction experienced in the game as familiar. According to their perspective, there is a general sense of dissatisfaction in the Netherlands with DBFM(O) contracting because companies experience a low-profit margin and high risks. The participants pointed out that difficulties in the implementation of some $\mathrm{DBFM}(\mathrm{O})$ arrangements were due to the high appetite of the market to accept any risk. Recently, the procurement authority is more careful in transferring risk during the tendering process, and the ministry in charge is less enthusiastic about introducing new concessional PPPs. Furthermore, the game brought into discussion the extent to which $\mathrm{DBFM}(\mathrm{O})$ contracts should be actually regarded as a partnership between public and private actors. One practitioner familiar with alliance PPPs pointed out that she did not see any of the typical incentives for collaboration in the game such as sharing risks, losses and gains. Consultants added that the "partnership"label for DBFM(O) contracts is rather misleading as they are nothing more than private finance initiative (PFI) models. According to them, collaboration is reduced to the expectation of "helping each other" only until the point where it is "safe". Taking into account that collaboration (samenwerken) has a strong meaning of working together in the Dutch culture, the actual implementation of DBFM(O) contracts is seen as not being fundamentally different from a principal-agent relationship. In this line of thought, an experienced procurement officer explained that poor communication is typical in the implementation of DBFM(O) contracts. Constraints of the project are born in the tender phase. Actors lose sight of the initial goals of the project given their natural habit to assume that the mission of the project can be reduced to the fulfilment of contractual obligations.

The absence of a feeling of partnership in the game triggered diverse opinions on the extent to which one should expect (and encourage) a team identity at the project level in practice. Some consultants who had experience in $\mathrm{DBFM}(\mathrm{O})$ contracting suggested that people usually forget organizational boundaries. While it is popular to refer to project teams, they are actually composed of people representing different organizations with an agreement. Contractual parts do not develop grounds for communicating, addressing dilemmas and in general, governing the interaction beyond the agreement. Other participants tended to disagree, pointing out that interaction over time and task at 
hand shape a situation where members from different organizations develop a team identity, and the project itself tends to have higher priority than the parent organization mandate. However, for other participants, this phenomenon was regarded as "projectitis", which is undesirable, taking into account that managers are employees complying with mandates and not entrepreneurs making decisions. The private project manager is not "playing with his own money", nor can the public manager make a personal decision due to his duty to follow regulations in a long chain of authorizations. Therefore, sustainable collaboration in a project cannot rely on personal grounds, but rather on the objective alignment of interests between parent organizations and their materialization in agreements. Plus, stable staffing for 20 years is not realistic as people usually decide to move on after a couple of years, which implies that the agreement remains the basis for building mutual interest between newcomers.

\subsubsection{Second Game Session - Market/Project Level Outcomes}

The game session included three rounds of tendering invitations and corresponding project implementation. Two firms were competing. At the market level, the observations revealed that the head authority aimed at procuring the projects as soon as possible, and the terms of the tenders were prepared without waiting for feedback from project implementation. The interaction at project level depended on the initial terms of the tender conditions. Table 4.5 summarizes the performance of key indicators of the game.

The performance indicators show a contrast between the dissatisfaction experienced by managers in the first tender and the satisfactory experience in the other two tender rounds. Discontent in the execution of the first project resulted from the impossibility to enforce road quality as there were no penalties in comparison to the high availability rewards according to the initial terms of the contract. The private project manager was not compelled to invest in road quality as the contract did not provide an incentive to do so. The mutual satisfaction in the second project was due to the joint focus on efficiency instead of quality and availability. Managers claim that their "business case" was agreeing on poor performance in the ongoing project in order to "earn" some money for next projects. Nevertheless, the head of the authority pointed out that the poor performance was not satisfactory from his perspective. The satisfaction in the last project was due to the tender in which only one firm handled an offer. As the tender included a fixed price, the remaining company presented an offer with a threshold of $150 \mathrm{Ql}$, the maximum deterioration to be simulated by the systems dynamics model. The rather soft implementation of the project was surprising for the project manager, who was not aware that the system would not score more than 150 QI. The head of authority accepting the offer and the winning CEO also declared that they were not aware of the boundaries of the physical system simulated by the systems dynamics model. In general, the game environment was less competitive than the one observed in the mixed group of practitioners due to the previous ties between colleagues and similar background. Table 4.6 summarizes the perceived type of interaction by individual players. 


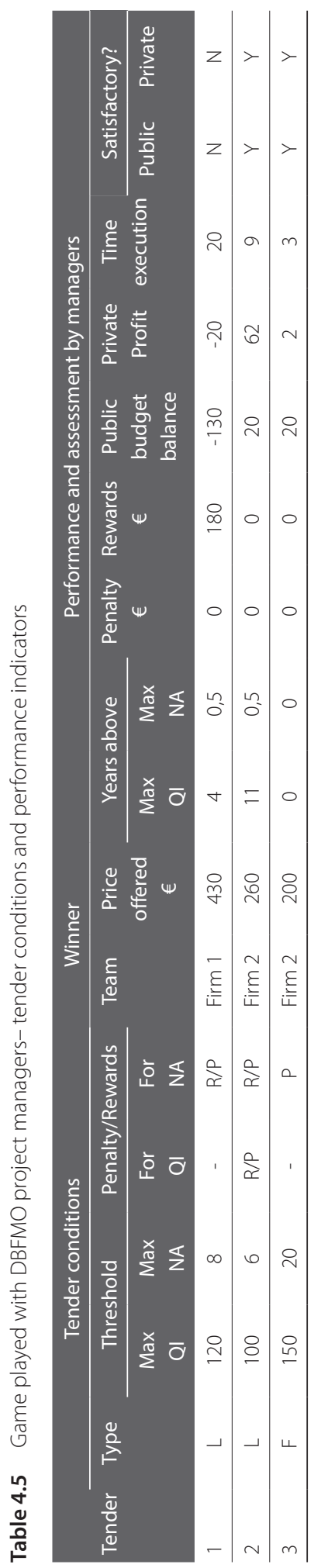


Table 4.6 Interaction assessment - game session with DBFMO project managers

\begin{tabular}{|c|c|c|}
\hline Relation & Role & Reflection \\
\hline \multirow{2}{*}{$\begin{array}{l}\text { Authority } \\
\text { head and } \\
\text { CEOs (Market } \\
\text { mediated) }\end{array}$} & Authority head & $\begin{array}{l}\text { "We, as an authority, got under pressure because we were low on money. } \\
\text { We tendered expensive contracts which ended up costing even more." }\end{array}$ \\
\hline & CEOS & $\begin{array}{l}\text { "Our company only tried to fulfil the authorities'specifications and deliver } \\
\text { quality as required, also keeping in mind that we, as a company, have to } \\
\text { make a profit. Also, that is why we did not make an offer for the third tender } \\
\text { because we could not manage the request of quality for the fixed price. } \\
\text { Better to be honest than have a problem afterwards in the project." }\end{array}$ \\
\hline \multirow{4}{*}{$\begin{array}{l}\text { Authority } \\
\text { head and } \\
\text { project } \\
\text { managers } \\
\text { (Hierarchy) }\end{array}$} & Authority head & $\begin{array}{l}\text { "I wanted my project managers to do their job within budget. I decided to } \\
\text { give them an extra budget, so this helped them, in my opinion." }\end{array}$ \\
\hline & \multirow[t]{3}{*}{$\begin{array}{l}\text { Public project } \\
\text { managers }\end{array}$} & $\begin{array}{l}\text { "We have a fixed price of } 200 \text {, penalties for } 20 \text { and } 50 \text { bonus. } 250 \text { received } \\
\text { from the authority and } 50 \text { left. So that was not so bad." }\end{array}$ \\
\hline & & "We had to earn money for the other projects." \\
\hline & & $\begin{array}{l}\text { "I needed more money since we closed a bad contract, but I didn't get it } \\
\text { because the head said I had to negotiate better. I was in a bad position to } \\
\text { negotiate because we didn't set a penalty on higher QI and at the same } \\
\text { time, kept on paying a bonus per year because of good availability." }\end{array}$ \\
\hline \multirow{5}{*}{$\begin{array}{l}\text { CEOs and } \\
\text { project } \\
\text { managers } \\
\text { (Hierarchy) }\end{array}$} & \multirow[t]{3}{*}{ CEOs } & "We prepared the bid together, and we are one company." \\
\hline & & $\begin{array}{l}\text { "Money was important for the state, so we adjusted the offer accordingly } \\
\text { and aimed to gain the bonus." }\end{array}$ \\
\hline & & "The cost price of the maintenance, plus arguing about risk led to our offer." \\
\hline & \multirow{2}{*}{$\begin{array}{l}\text { Private } \\
\text { project managers }\end{array}$} & "All for the company. We work together for the tender in the competition." \\
\hline & & $\begin{array}{l}\text { "We cooperated and discussed as one company and made an offer in the } \\
\text { light of one company objective to earn as much as possible with as little } \\
\text { cost as possible". }\end{array}$ \\
\hline \multirow{5}{*}{$\begin{array}{l}\text { Public project } \\
\text { manager and } \\
\text { private project } \\
\text { manager } \\
\text { (Project) }\end{array}$} & \multirow[t]{3}{*}{$\begin{array}{l}\text { Public } \\
\text { project managers }\end{array}$} & $\begin{array}{l}\text { "We constantly consulted each other and did not have to deploy } \\
\text { maintenance in between. Also no fines, as a result of which the authority } \\
\text { issued and the contractor received } € 200 \text {. In general, we were satisfied." }\end{array}$ \\
\hline & & $\begin{array}{l}\text { "The public manager had to earn money for the next projects, and the } \\
\text { private company wanted to earn money for maintenance." }\end{array}$ \\
\hline & & $\begin{array}{l}\text { "We helped each other a bit since in one year she decided to do high } \\
\text { maintenance, but she did not have to do it. I wanted it because the QI was } \\
\text { getting higher and higher." }\end{array}$ \\
\hline & \multirow[t]{2}{*}{$\begin{array}{l}\text { Private } \\
\text { project manager }\end{array}$} & $\begin{array}{l}\text { "I found it difficult because the boundaries within which we had to act and } \\
\text { cooperate were not entirely clear." }\end{array}$ \\
\hline & & $\begin{array}{l}\text { "I helped because it was a game. The relation was preferred instead of the } \\
\text { contract, like a daily business." }\end{array}$ \\
\hline
\end{tabular}

\subsubsection{Second Game Session - Reflection on PPP Practice}

Practitioners regarded the constrictions for collaborating at the project level as familiar due to contracting misspecifications. Nevertheless, they also argued that concessional PPPs provide space for developing a sense of partnership. They explained that in the exploitation phase, the roles of client, user and public project manager are assumed by new people who often have to face the hidden 
defects and even contract misspecifications of the first years. During that period, actors have to engage in the process of interpretation and discussion of the contractual clauses, including the execution of penalties. In their experience, managers can carefully place between brackets penalties for some issues with the expectation to find a "better solution" for all. In other cases, they aimed to make clear to the contractor that "if you give less, we also pay less" by pushing the contractor to provide evidence of service. As the relationship between public and private project manager usually implies a continuous discussion and interpretation of levels of service and contractual obligations, collaboration emerges from the clarity and fairness in the implementation of penalties. An element that reinforces the feeling of partnership is the more corporeal experience of service in managing buildings compared to the management of roads. Colocation in the same physical area facilitates a closer interaction with the counterpart breeding the working relationship.

The process of collaboration building is critical in two specific situations. First, managers pointed out that all kinds of risks were transferred to the market by the procurement authority in some cases. These risks were accepted given the high appetite of contractors, even if they were not able to autonomously manage them. When the public project managers monitor the performance in the light of the risk transferred, the private counterpart argues that "it is a partnership (and therefore) we should work together". Here, the task of public project managers is to avoid re-taking the transferred risk, but also to assess how to move forward in the project. Reflecting from the contractor position, the typical 30-year long-term agreement can induce a long-lasting financial situation which restricts the room for collaboration. Second, project managers have to deal with the sceptical attitude of clients and parent organizations about DBFM(O) performance and fairness. A special case is the introduction of functional changes that require extra investment from the user, who usually expect either a lower price or a higher service level than offered by the contractor. Here it was pointed out that public and private project managers are usually confronted with distrust from actors in their own organizations. In this situation, the relationship built over time provides the background against which the public project manager assesses if the price offered by the contractor is fair. Trusting behaviour is reinforced by the long-term nature of the contractual obligation, increasing the chances of penalizing circumvent behaviour in future interactions. Therefore, the core of the project manager's job is developing an informed criterion for assessing the integrity of contractor proposals, as well as minimizing the discussion with the user of the building by means of clarifying the scope of the agreement and what the user can expect (or not) from a DBFM(O) contract.

\subsection{DISCUSSION}

The process management literature argues that satisfaction emerges from re-creating the sense of partnership and legitimacy when addressing project issues (Klijn, 2008; Klijn et al., 2007; Verweij et al., 2013). The key to successful PPPs is the legitimacy of decisions and outcomes along the project life cycle. However, the process management literature is sceptical about re-creating legitimacy and a sense of partnership in the implementation of concessional PPPs (Klijn et al., 2007). Execution of PPP concessional contracts resembles a zero-sum game for managers, given the absence of embedded social structures enabling the re-creation of the partnership over time (Klijn et al., 2007). To explore 
the possibility to re-create sense of partnership in concessional PPPs, we developed the 3 P challenge game and played it with a mixed group of practitioners and a team of public project managers. The 3P challenge offers a space for engaging in collaboration to address project issues, but it also includes mechanisms that prevents players from making use of this space.

Reflecting on the gaming mechanisms that prevented collaboration in the gaming sessions, our results indicate a strong contrast between the perspective of the two groups of players. While the second group comprised by DBFMO public contract managers explicitly recognized the emergence of a sense partnership in their practice, the first one including experts of consulting organizations declared that the objective structure of DBFM incentives impedes such a type of working relationship. The literature already noted that concessional PPPs are fundamentally different from a principal-agent relation, but good relations between managers soften problems emerging in concessional PPPs (Lenferink et al., 2013). Our results build upon this argument, indicating that a sense of partnership emerges from the process whereby managers approach and resolve project issues. Project managers are continually challenged to consider different and contradictory stakes. The contractual provisions for capturing value for parent organizations impose an objective demand to managers in concessional PPPS. Yet, this demand can be subjectively assessed by the person enacting a project management role in the specific context of interaction. While the contractual provisions serve as a reference for defining enforceable obligations, the outcomes dealing with project issues in concessional PPPs are also judged in terms of legitimacy by the grid of actors with a stake in the situation. Therefore, a sense of partnership in concessional PPPs emerges as a relational good from re-creating clarity and fairness in the process of executing front-end agreements.

The two different outcomes of the gaming sessions provide evidence for the layered nature of project manager positions, setting the structure of divergent demands faced by project managers (DeFillippi \& Sydow, 2016; Sydow \& Braun, 2017). The mixed group of practitioners pointed out that concessional PPPs are not real partnerships, emphasizing the role of project managers as employees that should execute the front-end agreement for the sake of their organizations. From this normative standpoint, the first gaming session brought forward the permanent but contingent nature of the objective relationship between public and private project managers as members of different parent organizations (BenitezAvila et al., 2019). The idea of concessional PPPs as zero-sum games operates upon this identity of project managers as part of permanent organizations (Klijn et al., 2007). Players disregarded the idea of project teams upon the negative connotation of "projectitis". By doing so, they indirectly acknowledged the existence of a conflicting interface between the project and parent organizational levels due to the vested interest of project actors diverging from parent organizational expectations. In the gaming session with public contract managers, players explicitly pointed out that concessional PPPs offered a space for breeding a sense of partnership and collaboration at project level. The mutual dependence triggers dialogue and emphasizes the necessary but temporal relationship between public and private project managers with a more positive tone (Benitez-Avila et al., 2019).

In this context, managers in the second game framed their role as brokers of multiple interests (Fleming, Mingo, \& Chen, 2007). They bring into play contractual obligations to clarify performative and value expectations between users, parent organizations and counterparts. This sense of transparency, clarity and fairness built over time provides extra-contractual grounds for legitimizing practices such 
as blending contractual dispositions or asking and giving concessions to the counterpart. Time was the critical element to understand the process through which project managers develop innovative ways to enact the PPPs' concessional governance structure. The long-term nature of concessional agreements seems to operate as the mechanism to trigger reciprocity and eventually trust beyond the accurate front-end risk allocation. Here it is important to note that brokering refers to a position which is necessarily relational and emerges from the subjective enactment of a contractual form, which can also be executed in a rather mechanical way (Donati, 2016). Creative enactment of contractual obligations is building a working relationship based, but not reduced to, objective bounds defined by contractual obligations (Benitez-Avila et al., 2019; Donati, 2013).

Therefore, turning project issues into an opportunity for developing a sense of partnership depends on how managers enact contractual obligations. The different attitudes adopted by players assuming the role of public project managers in the first gaming session made clear that people assume roles with a higher or lower level of subjectivity. Showing appreciation for the other's stake was a key element for satisfaction in comparison to the experience of players focused on controlling the simulation. Moreover, it allowed players to reduce losses and provide arguments for legitimizing the poor outcome as a result of their control. Addressing problems in concessional PPPs relies on the mobilization of additional investments from parent organizations. In the second gaming session, the players' reflection explicitly considered the constrictions imposed by front-end project decisions and the path of interaction. The players explained how they blend contractual disposition to move the project forward in their practice, addressing poor ex-ante choices and engaging dialogue within the boundary conditions of the contract. In their practice, a satisfactory working relation stems from taking as reference contractual obligations (they are not avoidable) but leaving open the opportunity to build working relations over time.

Time and space for building collaborative relations are not unknown themes in organizational and project organizational studies (Gulati \& Nickerson, 2008; Lewicki \& Bunker, 1996; Meyerson, Weick, \& Kramer, 1996). But usually, trust-building is still framed as voluntarist outcome of actors (Poppo \& Zenger, 2002), sometimes facilitated by external systems of shared meaning (Bachmann \& Inkpen, 2011; Swärd, 2016). Our findings call for better articulating trust development based on actors capacity to reflect on their objective basis of the working relationship (Archer, 1995; Donati \& Archer, 2015). In other words, trust cannot be reduced to the psychological dispositions of people as individual entities. Beyond its psycological dimension, trust is a property of a relation. In particular, trust is the relational surplus emerging from subjectively enacting of objective organizational bonds and predicaments. When we state that sense of a partnership is a relational good, we frame it as an external reality (but not reduced) to individual psychological dispositions (Donati, 2015).

The autonomy of sense or partnership as relational good is manifested in the fact that managers blend contractual disposition based on the present surplus of their past interactions. And at the same time, blending contractual dispositions aims not only at re-creating their psychological feeling of reciprocity but also the compliance with the objective demands that their dual position entails. Furthermore, interactions are considered legitimate because they are aligned with the objective demands that impose the dual role of managers. Trust literature has overlooked the role of reflexivity to link individual dispositions and the multiple and conflicting demands imposed on people in organizational situations. 
Reflexivity allows individuals and groups to consider themselves in relation to their (social) context and vice versa (Donati, 2015). Therefore, reflecting on the objective demands as setting the grounds (but not reducing) working relationships enables individuals to define reciprocity upon the expectations of "doing their best"for concealing conflicts.

\subsection{CONCLUSION}

While serious games as research tools have been used to transfer insights from a controlled setting to reality (Altamirano \& de Jong, 2009), the P3 challenge game is a research tool designed to activate reflexivity of players to provide insights into the implementation phase of concessional PPP projects and the agency of project managers. This paper reported on the game application to understand the possibility of collaboration in concessional PPPs. The results suggest that the game provides an experience where participants run into conflicts, given the competitive pressures, the difficulty to define accurate tender conditions, and the uncertainty and emerging interaction of players assuming roles. The game activated a reflection on the multiple demands phased by managers in charge of executing concessional PPPs in their exploitation phase and their capabilities to build a working relationship based upon the creative enactment of contractual obligations. The game offers a venue to discuss the objective constrictions to develop this sense of partnership shaped by concessional PPPs, and by doing so, the debriefing encouraged participants to identify in their practice the agential powers to creatively enact contractual obligations.

The lessons for concessional PPP projects are clear. PPP project managers should make an effort to make sense of contractual obligations considering their dual position as members of the temporal and permanent organizations. They should aim for fairness by considering their obligations in relation to their context and vice versa. This context includes the obligations of the counterpart in the same dual position, being responsible for pushing the project forward while observing parent organization stakes. Only after building a sense of fairness can project managers legitimately advance practices such as blending contractual dispositions or placing brackets around some clauses. In other words, managers should aim at building a working relationship stemming from (but not reduced to) the objective demands imposed by contracts and organizational mandates. These relations operate under managerial skills as a broker of interests up to the point that value conflicts do not fundamentally affect parent organizations' core values and interests. Therefore, arranging PPP agreements with accurate allocation of risk and responsibilities remains a critical task.

There are theoretical gaps to be considered in the process management of concessional PPPs. On the one hand, the theory of process management is based on the idea that legitimacy is the key to success. In our analysis, managers attribute satisfaction to interactions which lead to legitimate outcomes. Yet, these legitimate outcomes are defined by the way that problems are solved but not necessarily the quality of the outcome as such. Future research should clearly define the extent to which subjective managerial satisfaction relates to objective performance indicators, acknowledging the diverse standpoints of success definition (Atkinson, 1999). On the other hand, the impact of concessional PPPs on managerial collaboration might be more related to the shadow of the past or future. Beyond the 
accuracy of front-end risk allocation, the emergence of trust and partnership as relational good might be more supported by managers perception of long-term engagement that pushes them to "build" a working relationship. What remains unclear is how the sense of partnership as a relational good built by people filling organizational roles changes or remains with the dramatic turnover of actors typical for concessional PPPs (South et al., 2018). Finally, the 3P challenge game provides a fundamental lesson for games supporting collaboration. First of all, games can make a point of the hypnotic power of calls for building collaboration when the actual configuration of incentives in practice set up zero-sum games. In the debriefing part, players are able to take a critical distance of current ways of organizing and employ their capacity to build relations for overcoming the structural predisposition leading to adversarial interaction.

There are a number of limitations to our research. First of all, the game does not fully articulate the role of lenders in the ex-ante governance design and governing activity during the implementation of concessional PPPs (Dupas et al., 2011) or the current procurement procedures such as competitive dialogue (Hoezen, 2012). Therefore, the gaming experience can be further developed in that direction. The discussion on partnership promises needs to be understood in the Dutch context, which has been characterized as a corporatist culture. It can be the case that in another context, other values and meanings of partnerships are taken to reflect on the consequence of PPPs. In this regard, future research can explore the extent to which the game triggers similar reactions of PPP practitioners in another national context - in particular, the extent to which practitioners recognize themselves as a broker of interest in the execution of concessional PPPs.

\subsection{ANNEX: SYSTEM DYNAMICS GAMING PLATFORM}

The development of the "3P challenge" includes a system dynamic simulator for supporting player estimations of capital investments, maintenance plans and expected performance, based on the Highway Design and Maintenance Standards Model (HDM-III) previously developed for the World Bank (Watanatada et al., 1987). The HDM-III model is based on a deterministic conceptualization of the pavement deterioration in order to simulate life-cycle costs of highway construction, maintenance and vehicle operation. In particular, the game is based on road deterioration and maintenance submodel (Watanatada et al., 1987). It "estimates the combined effects of traffic, environment and age on the condition of the road, given data on its construction and materials, and proceeds year by year to predict the change of surface condition under specified maintenance and rehabilitation policies" (Watanatada et al., 1987, p. 67). For the game purposes, the HDM-III road deterioration and maintenance submodel was simplified and programmed as a System Dynamic simulation. System Dynamics modeling has been used for capturing the dynamics of road deterioration, providing insights on optimal maintenance policies (Fallah-Fini, Triantis, Rahmandad, \& de la Garza, 2015; FallahFini, Rahmandad, Triantis, \& de la Garza, 2010) and the optimal length of concession periods (Xu et al., 2012; H. Zhang, Jin, Li, \& Skibniewski, 2017). In comparison to the optimizing concern, the use of the System Dynamic model in this research is providing a realistic representation of the project in order to enrich the game experience. Therefore, the modelling process was guided by the deliberative simplification of the model, having in mind the need to balance the three independent so-called 
worlds of reality, meaning and play for convening the experience a serious game (Harteveld, 2011). This implies simplifying deterioration system components modelling and prioritizing behaviour validation over structure validation (Barlas, 1996), as it is not the primary objective to understand how deterioration behaviour emerges from the system structure.

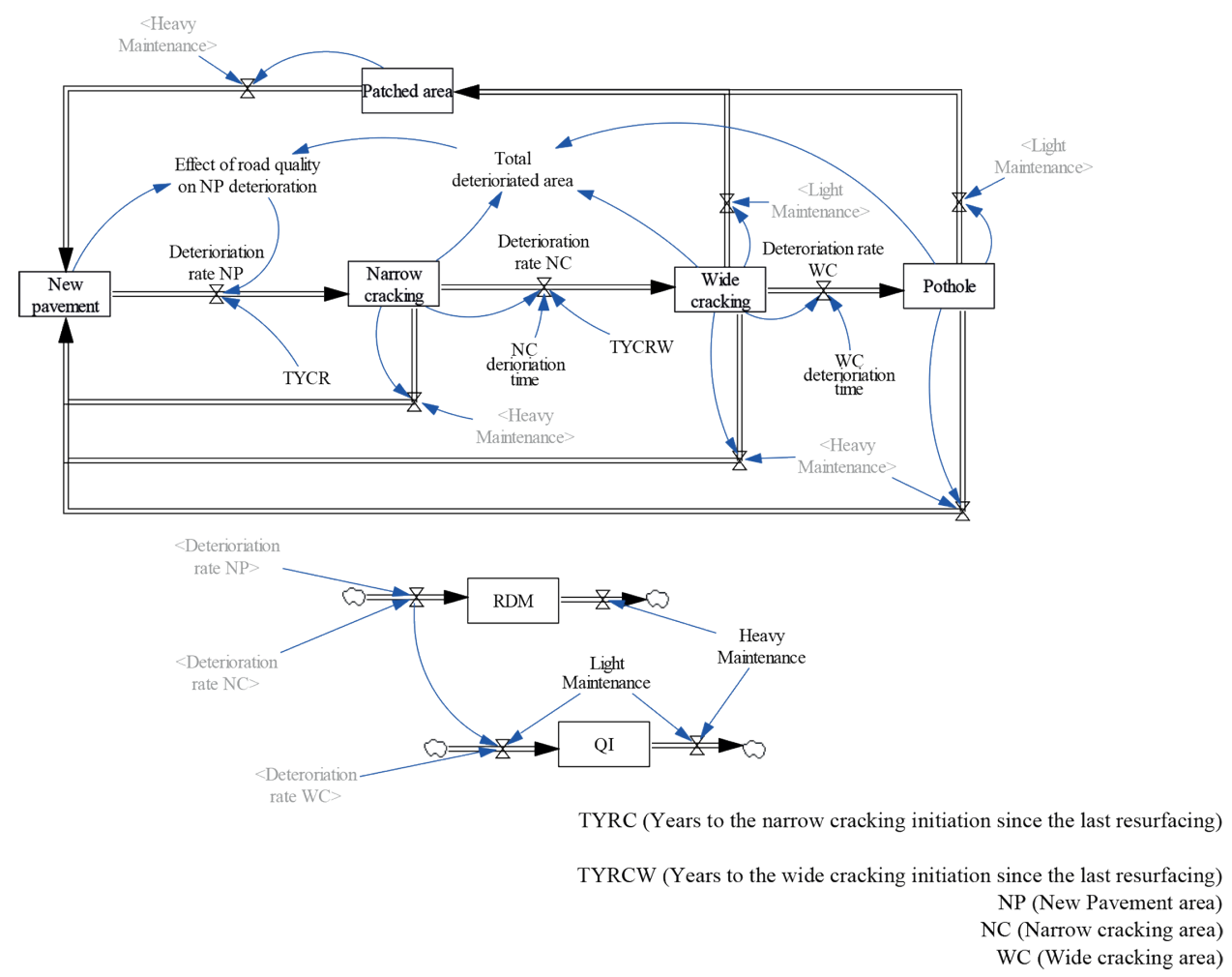

Figure 4.2 Stock and flow diagram for the deterioration and road maintenance

In short, the core of the deterioration and maintenance model consists of five stocks closed system representing different levels of pavement distress: new pavement (NP), narrow cracking (NC), wide cracking $(\mathrm{WC})$, and pothole(PO) ${ }^{24}$. The simulation represents how the initial area starting at the "new pavement" stock transits to different deterioration stages, due to traffic, environment and age. The increasing levels of pavement distress lead to higher rut depth (RDM $)^{25}$ and deviations of a surface from a true planar surface (measured as a roughness index-QI). This roughness index is the key variable to assess service, as higher deviations directly affect "vehicle dynamics, ride quality, dynamic loads and drainage" (Watanatada et al., 1987, p. 73). The simulation defines a range for possible initial values of construction and materials, representing the capital investments that can affect deterioration rates. For maintenance policies, the simulation includes an extra stock representing the patched area, which is governed by the implementation of light maintenance activities. For the sake of simplicity, the full deterioration process of the patched area was omitted, but instead, the model includes a direct non-

\footnotetext{
${ }^{24}$ For simplicity, the model does not include revelling area.

${ }^{25}$ Maximum depth under a given straightedge placed transversely across a wheel path.
} 
linear relationship between the patched area and the rate of QI change. High maintenance activities resemble complete reconstruction, "resetting"the entire system to the original conditions (100\% of the area in the new pavement stock and $\mathrm{Q}=0$ ).

The flight simulator is used for supporting the definition of capital/maintenance front-end choices under the competitive pressure at the market level (Figure 4.5). In the game, firms have to prepare their economic offers supported on the simulation, while the authority does not have access to it. The flight simulator has three areas: extra-capital investment, maintenance investment over time and key indicators to track road performance. Extra-capital investments can enhance strength coefficients (investing in the quality pavement) and layer thickness (investing in layer thickness), within the range set by Watanatada et al. (1987). Additionally, for increasing playability, players can invest in higher predictability of the deterioration rate ${ }^{26}$. Capital costs are fixed. Maintenance activities can be activated along the 20 years of the simulated project, having a fix and marginal cost depending on the area deteriorated. Key indicators include the visualization of the service variables (QI roughness index and non-availability - days closed for deploying maintenance activities), pavement quality (distress stocks), total cost (capital and maintenance costs) and a summary of the critical indicators over time.

On another hand, the multiplayer online game provides the possibility to introduce modifications of the maintenance choices upon the emergence of uncertainties (Figure 4.4 and 4.5). This possibility is a fundamental characteristic of the game at the project level, as it emulates how front-end project assumptions (defined by firms using the flight simulator) change once future (and uncertainty) unfolds. Therefore, the System Dynamic model that supports the online game modifies, randomly, the number equivalent of standard axle loads per year (traffic). Given the high-sensibility to this parameter, when managers have to implement the "winning" offer at the project level, they "run into the surprise" of sooner or faster deterioration. Once the players run the online simulation for the 20 years, both of them share the final screen reporting the performance of the key indicators. It includes information on the total years where the service level was below than the defined threshold (total years high QI and total years over max day closed), payments from the authority to the contractor (including awards), penalties paid by the contractor to the authority, expenses to payed to the bank (capital expenditures and maintenance operations), and a summary of the losses of the project, which require to be settled by the managers before closing the project.

\footnotetext{
${ }^{26}$ In order to represent higher or lower predictability, the "deterioration times" were modelled as normally distributed random numbers using as mean the original time estimated for replicating Watanatada et al. (1987) model and a standard deviation defined by player decisions (Range 0,4 to 0,001) The higher the investment, the lower the standard deviation.
} 

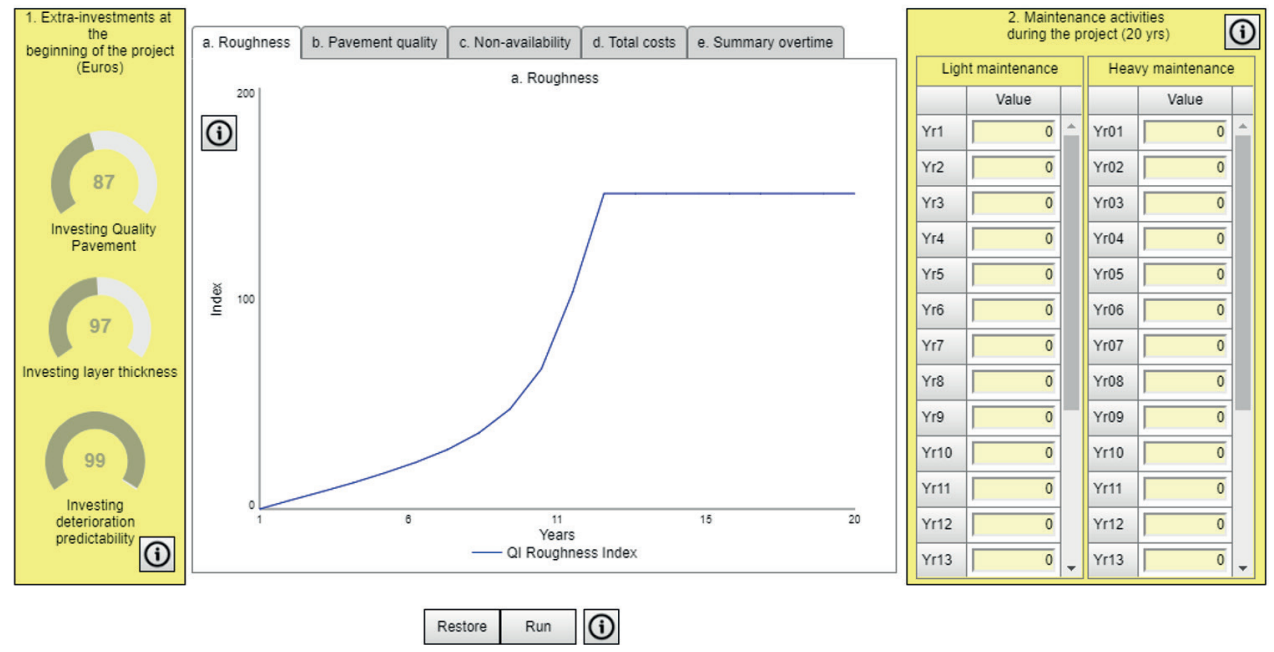

Figure 4.3 Flight simulator for preparing economic offers at the market level

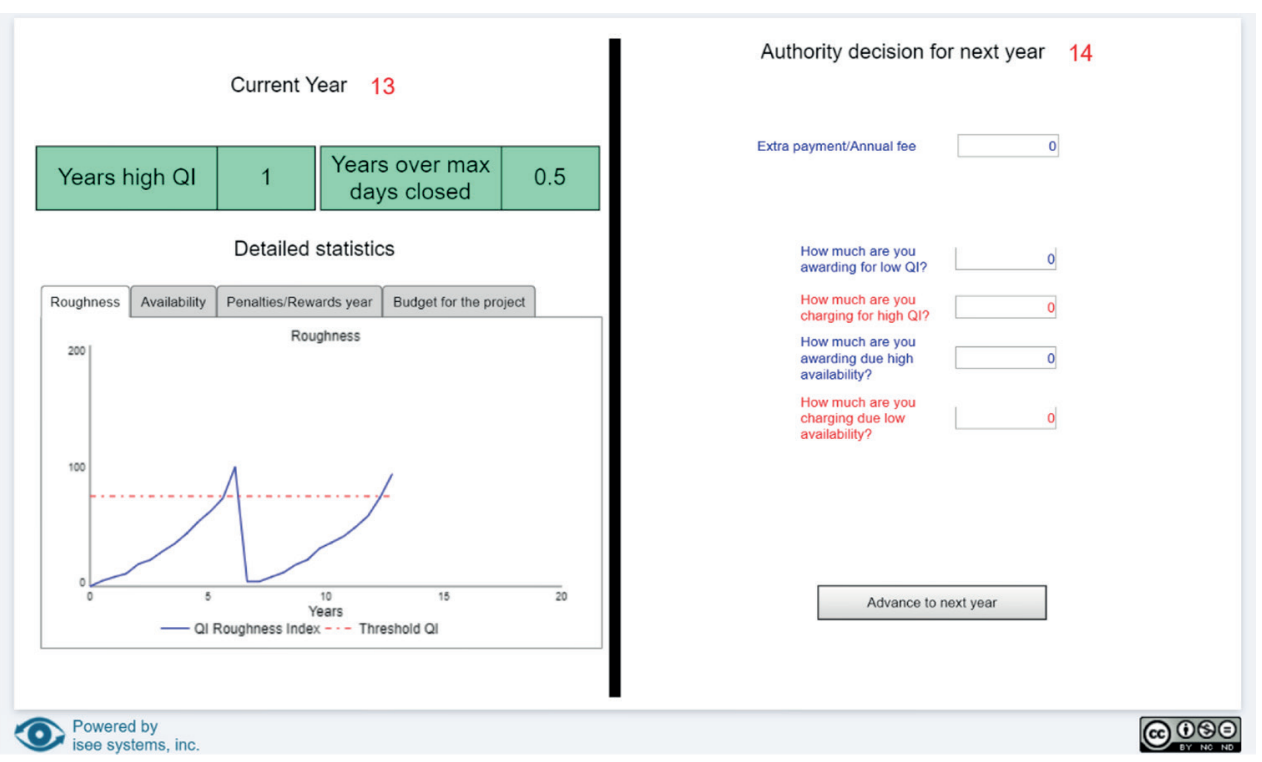

Figure 4.4 Online game screen for implementing the project year by year (Authority) 


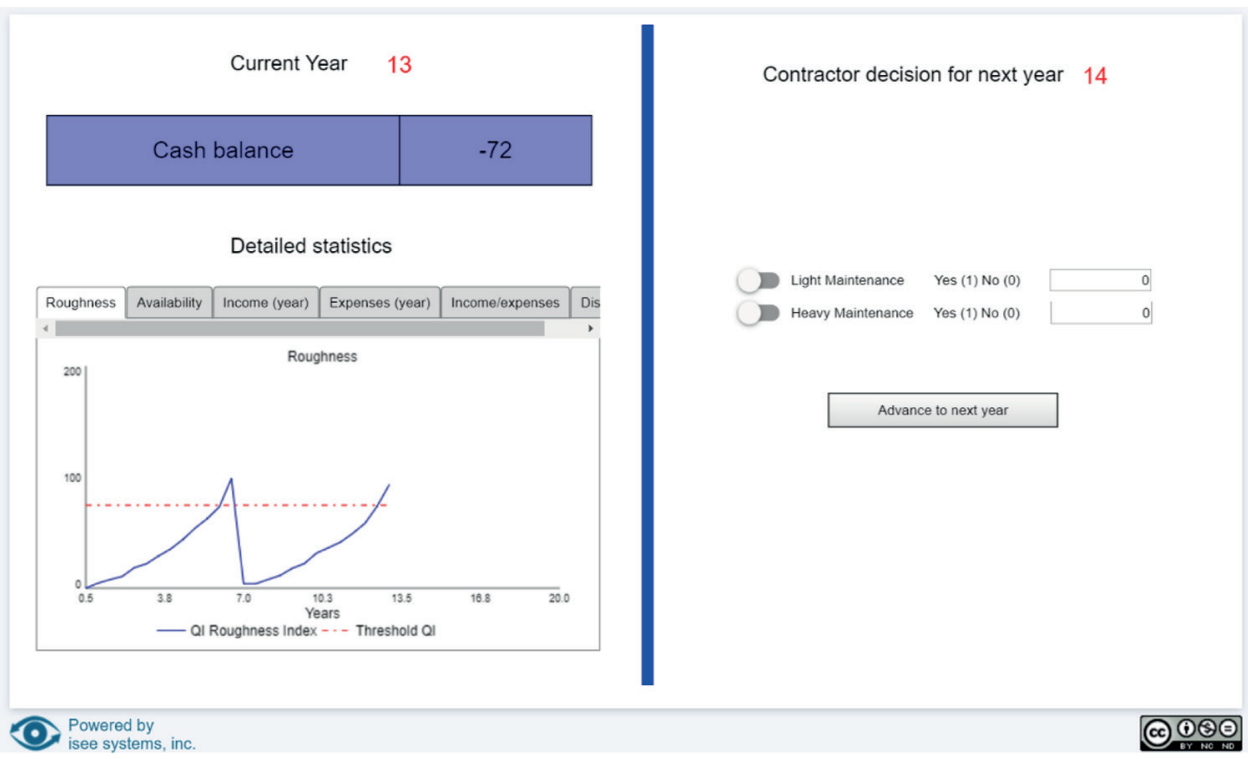

Figure 4.5 Online game screen for implementing the project year by year (Contractor) 
Public-Private Partnerships are popular organizational arrangements for the delivery of public infrastructure, with strong advocates but also fierce critics. This paradoxical condition is related to the multiple dimensions to be considered in the design of PPPs governance structures, ranging from purely efficiency expectations to judgments on social legitimacy. Once the governance materializes in a project, internal and external disturbances challenge the initial assumptions that enabled the engagement in such a long-term process of value creation. Even when engineering and economist perspectives of PPP project governance are aware of uncertainty and complexity, there is a tendency to assume that the "right" front-end organization and fences guarantee satisfactory projects. The turn-tosocial theory reminds us of the actuality of projects going beyond normative governance approaches aiming to control and predict the future. Projects are open systems, exposed to contingency and unforeseen circumstances. There is always a potential to transform for the future what has been already organized in the past. Governance becomes an ongoing activity predisposed by the results of past interactions and cannot be isolated from its context. Relations between people filling project positions are then built upon objective bounds and subjective interactions over time. Accordingly, this PhD undertaking endeavoured to address:

\section{How do managerial agency and project governance structures rely on and re-shape each other during the O\&M phase of PPPs?}

To answer this question, this dissertation took as a research perspective the logic of discovery/ explanation of Critical Realism. From this standpoint, the value of empirical research is validating/ refining existing theoretical hypotheses to account for an observable phenomenon, which is causally dependent on mechanisms that are not directly observable. We aimed at unravelling the interconnections between the cycles of change and reproduction of project governance in ongoing PPPs and the macro-level process of policy change. Accordingly, we examined the relational and contractual activity dealing with uncertainty and displaced-agency problems during the $O \& M$ in the policy context of re-legitimization close public-private relationing in the Netherlands. For this purpose, we defined the nature of public and private managerial agency as the ability of somehow constrained actors to (re)create control and autonomy relations at the project, organizational and field levels. We also structured our research design in three analytical stages. First, we tested the empirical relationship between contractual and relational aspects of governance according to the prevailing theoretical perspective of neo-institutional economics. Then, we re-conceptualized governing mechanisms in a process framework, engaging a theoretical dialogue between the view of realist social theory on agency-structure interplay, PPP literature and the multilevel view of project governance. In the third stage, we collected new empirical data to study these new concepts of governing mechanisms in the changing field of PPPs relations in the Netherlands. We selected three projects in their exploitation phase whose tendering conditions reflected different policy values towards the desired level of private autonomy in PPPs. Finally, we engaged with practitioners to reflect on their governing activity at the project level in the context of policy change, based on a serious-game designed in line with the scientific perspective of this research. 
According to our research, relational aspects mediate the impact of PPP contracting on the perceived project performance. These relational aspects are highly dependent on the PPP paths, where managers have to address multiple demands given their dual position as a member of temporary PPP teams and permanent organizations. Addressing diverging demands at the project and organizational levels depends on enacting contractual obligations with a certain degree of subjectivity to build a working relationship not reduced to contractual exchanges. This creative enactment of contractual relations opens a space for altering the configuration of control and autonomy relations embedded in contractual forms. Likewise, the inherent value attributed to relational aspects during the procurement phase facilitates or hinders the possibility to frame a PPP working relationship beyond contractual exchanges. This phase, in turn, depends on the control-autonomy relations and practices which, for the time being, are legitimate in the PPP field. In the Netherlands, the PPP field dynamics is driven by the necessary contradiction between the liberalization principles of DBFM(O) contracting and the traditional structure of public-private Dutch relations. The traditional Dutch organizing model (Rhineland model) operates upon close negotiated cooperation, rather than discrete allocation of responsibilities between public and private organizations as DBFM(O) prescribes. While there is an increasing re-legitimization of close collaboration at field level, the dynamics of collaboration and conflict at the project level remains dependent on the cycles of (re)production of each publicprivate agreement. That does not mean that projects are closed systems. Necessary contradictions and context dynamics are manifested in conflictive situations, and diverse managerial expectations to deal with value creation and capture problems during O\&M phase. However, once the project governance structure is in place, it shapes internal positions project actors (e.g. project managers) and their vested interests. In the following lines, we explain in detail our argumentation and its implications along the specific research questions. Then, we discuss our theoretical, methodological and practical contributions. We close with research limitations and future research opportunities.

\section{RQ1: What is the relationship between governance mechanisms, managerial coordination, and performance in PPPs projects?}

Contractual and relational governance are usually conceptualized as discrete mechanisms, triggering partner's contribution and efforts to array project activity and performance predictability. Partners' contribution refers to tasks and activities for solving problems, which can be induced by contractual control, tacit understandings, or trust (Kadefors, 2004). Project performance is an evaluative concept based on satisfaction, given that different value claims and interests in projects lead to different perceptions success (Atkinson, 1999). Contractual governance limits the number of possible future project outcomes by allocating risks and setting enforceable standards aligned to the mission of the project. Relational elements of governance include relational norms and trust. Relational norms are informal rules of social exchange that provide tacit understandings on how to organize work (Macneil, 1980). Trust permits partners to operate under the expectation that the performer will refrain from opportunistic behaviour under an unspecified obligation of reciprocity (Blau, 1964).

Our results (empirically) tested the idea that project performance is the result of a mediation process. Relational governance elements (relational norms and trust) play their mediating role on the blueprint provided by contractual governance elements, and translate these contractual provisions into contributions of project partners leading to performance. Additionally, more considerable uncertainty 
requires stronger joint management, increasing the relevance of relational norms addressing substantive project issues. These findings allowed us to move away from the static substitution/complementarity dichotomy of contractual and relational governance to the discussion of governance from a process view. Relational norms initially emerge from the implementation of discrete contractual choice and then turn into an implicit understanding sanctioned by the strength of the informal ties built between partners. In this regard, relational norms compensate for long-term contractual governance design by defining partners' contribution, which nature and dynamics cannot be formalized as obligations to perform in advance. Additionally, partners' trust mediates the relationship between relational norms and partners' contributions. This stage of the research brought to light that governance interplay is better understood as a process of contractual governance enabling and constraining the impact of relational governance on partners contribution and finally project outcomes.

\section{RQ2: How to conceptualize PPP governance operation as agency/structure interplay at the project level?}

To justify the contractual and relational governance interplay as a process, we departed from the consideration that "the authenticity of the human experience [is] that we are both free and constrained" (Archer, 1995, p. 29). Accordingly, we introduced the sociological discussion of the interplay between agency and structure to better elaborate our initial process insights into contractual and relational governance. As reference, we took realist social theory and its morphogenetic approach to suggest a sui-generis morphogenetic cycle at the project level. In our conceptualization, the governing activity we see in the present is the outcome of creative human mediation of structural governance conditioning inherited from the past. This implies that governing activity can change the project governance structures for the future. In this cycle, the point of contact between agency and structure is the socalled positioned-practice. Enforcing contracts, bringing together stakeholders or engaging informal dialogues are positioned-practices, enacted and recreated by virtue of managers' dual positions at both the partnership and the parent organizational levels.

We framed the structural properties at the project level as temporary but necessary relationships between actors filling managerial positions. According to this conceptualization, the performative demands of a public project manager necessarily require the operation of the private project manager regardless of the specific individuals filling those positions. These structural configurations predispose actors to engage solidarity or concessional ways of interactions. On the other hand, we conceptualized as permanent the relationship between parent organizations predisposing to competition and opportunism. This relationship is contingent because private and public organizations can operate irrespectively of the operation of the counterpart outside the PPP agreement. Project managers positions are also defined by this contingent relationship. They have to respond to performative demands defined by the rule-oriented nature of public organizations and the profit-oriented nature of private organizations. The postulated explanatory mechanism is the managerial capacity to reflect and bring creativity to conceal (or prioritize) multiple demands imposed by their dual positions and the resulting vested interest. The operation of this causal mechanism accounts for observable governing activity when triggered by project issues, unleashing the reproduction and change of project governance. 
We used a DBFMO project in its exploitation phase to illustrate the operation of the morphogenetic cycle and the operation of the causal mechanism. First, we noted that the dichotomy between substitution/complementarity for the governance interplay did not fully capture the project path dynamics. Contractual and relational activities sometimes operated as complements, in other times as substitutes and overall with some ambiguity. During the first years of the exploitation phase, public and private managers were confronted with the need to introduce changes in the scope of service due to users' demands. The DBFMO contractual principle was that the public manager had to define the levels of service, while the private manager was in charge of defining the best ways to deliver the service. However, during the first years managers placed the DBFMO scripts between brackets. In particular, they blurred the discrete allocation of contractual responsibilities for introducing new functional requirements during the operation of the facility. Therefore, they came up with the socalled extensive dialogue practice, to closely negotiate the scope of the initial facility changes and the related prices while clarifying their contractual roles. Once the interpersonal trust took over, the dynamics of interaction did not rely anymore on the extensive dialogue practice. Trust was reinforced by the adaptation of formal procedures to define price changes in the service scope. At the moment of collecting data, public and private managers identified themselves as a team.

This governing activity had as an underlying driver the public and private managerial struggle for building a favourable working relationship in a context of parent organizational pressures and scepticisms about DBFMO contracting. The development of collaborative relationships at project level demanded that both managers isolate project dynamics from external pressures. The identification of public and private managers as a team necessarily involved a struggle for autonomy in relation to the parent organizations. The team identity was the outcome of prioritizing the necessary relationships at the project level, and the resisting forces operating at parent organizational level pushing for opportunism and competence.

\section{RQ3: How does managerial activity unfold in relation to project structures during the O\&M phase of PPPs, in a dynamic organizational and field context?}

The third chapter makes the point that PPP contracts embody doings and values legitimized at the time of the procurement phase but continuously contested at field level during project implementation (Reed, 2001). These embodied doings and values are articulated in a historical configuration of public-private relationing. Accordingly, we compared the paths of three DBFM projects procured under different policy values in the Netherlands, examining how managers reflected and brought creativity to conceal (or prioritize) multiple demands. In this chapter, PPP offered an empirical setting to reconsider the interface between temporal and permanent in temporarily organizing (Bakker et al., 2016). The interface was blurred by the structuration approach of temporal organizing-as-perspective due to their excessive reliance on practices ignoring positions (Sydow et al., 2004). From the realist perspective, governance of the temporary emerges from the permanent but dynamic latticework of relations reflecting the different configuration of public-private relationing. In our cases, the N31 project was procured during the Dutch policy of "more value through collaboration", which emphasized soft aspects of cooperation aligned with corporatist Dutch tradition. The II Cohen Tunnel was procured under the policy "Market, unless..." reflecting the policy turn to liberalization in the context of new European procurement guidelines. The N33 was procured during the period of full endorsement to 
VfM principles when a governmental coalition aimed to pursue many projects as DBFM projects due to the financial crisis. The data collection and retrospective elaboration of narratives were carried out during the post-crisis period, when the policy discourse shifted back to the relevance of close publicprivate cooperation.

The formalization of contractual relationships led to temporary but necessary relationships, which are conflicting with the wider set of relationships structuring the working relationship between project actors. Once DBFM agreements were placed in practice, project actors faced the necessary contradictions between the embodied relationing of the contractual form, wider administrative structures through which projects took place, and habitual codes of work interaction. These were conditions which predisposed the governing interaction between public and private managers triggered by (i) endogenous conflicts emerging from executing DBFM contracts in an operational context, (ii) endogenous conflicts emerging from decisions made in previous cycles of interaction, and (iii) exogenous opportunities to modify the contractual agreements due to legislation changes. Governing activity relied on - but also (re)produced - the system of contractual penalties upon levels of service, and the principle of autonomy according to which the private actor defines the best ways to manage the asset lifecycle.

Now, the internal positions and vested interests emerging from the formal agreement imply that projects acquire a relational structure in their own right. Consequently, the structure of project governance changes in a path open to the environment, but not completely defined by exogenous dynamics. Usually, the change of initial project structures followed a process where parts changed in accordance with the blueprint of the governance structure (developmental morphogenesis). The observed radical change in the tunnel case emerged from the strong contradiction between the embodied relationing of DBFM contracting, and its mismatch with the operative context leading to arbitration. This case represented a unique creative morphogenetic cycle at the project level, as it implied changing the type of relationing from strongly discrete allocation of responsibilities to a more closely negotiated coordination. Furthermore, this project episode was the only one that seems to directly contribute to the re-valorization of relational aspects in the policy discourse in 2016 in the post-crisis economic context.

Therefore, the role of managerial agency in changing the structure of relations at field level has to be assessed beyond the frontiers of project boundaries and the postulated mechanism. The introduction of DBFM led to a process of informal regrouping of asset managers in a community of practice inside the RWS. Their initial concern was strengthening their managerial capacities in comparison to the well-established unit in charge of the construction phase inside the RWS. Eventually, the community of practitioners brought together managers from the two subunits for sharing knowledge, and fed the discussion on procurement adjustments inside the RWS and at the policy level.

\section{RQ4: How do practitioners reflect on their managerial agency in the implementation of PPP projects?}

Collaboration in the exploitation phase of PPPs relies on the managerial capacity to assess multiples demands, upon the creative enactment of organizations and contractual roles. Nevertheless, the initial 
terms of the PPP agreement shape project paths, conditioning the identification of managers as PPP teams. To engage practitioners with this idea, we designed the "3P challenge" game as a vehicle to reflect with practitioners on the working relationship during the exploitation phase of PPPs. In this game, players assume the role of project managers facing the challenge to collaborate and simultaneously comply with contractual provisions defined through ex-ante choices of players assuming the leadership role of parent organizations under competitive pressure. In this way, we created a situation where the contracting process led to the creation of temporary public-private project teams. Additionally, it allowed emulating the dual position of project managers previously conceptualized. The gaming sessions aimed to create an enabling environment of sharing insights into the ex-post PPP governing practices by contrasting gaming and working experience. The game dynamics offered a space for collaboration on the project level but also activated mechanisms preventing players from making use of this space. The game makes the point that managers can implement contractual mechanisms with or without much communication with the other party about what needs to be implemented. In the process of reflecting on the game interaction, practitioners articulate current concerns of PPP practice in the Netherlands, at field and project level.

In the session played with a group of mixed practitioners, participants pointed out the similarity between the experience during the game and the ongoing discussion of PPPs at the policy level. At the moment, the Dutch authority and market are less enthusiastic about engaging new PPPs, given the low margin of profit and high risk for contractors. Players assuming the role of firms in the game identified a similar situation. Consequently, the gaming experience allowed them to critically discuss whether public and project managers in PPPs are working teams. The prevalence of penalties as the mechanism to guide ex-post interaction in a so-called partnership implies a breach of meaning for practitioners, a living oxymoron. In the case of contract project managers, the same gaming experience allowed them to reflect on the objective demands of the contract as well as the top-down pressures of organizations. The discussion brought to light the characterization of their role as brokers of varied interests by blending the contract to move the project forward, addressing poor ex-ante choices, and dealing with uncertainty. Here it is important to note that brokering refers to a position which is necessarily relational and emerges from the subjective enactment of a contractual form, which can also be executed in a rather mechanical way. Then, the legitimization building process takes the form of building a sense of fairness and clarity of contractual obligations in concessional PPPs.

\section{THEORETICAL CONTRIBUTION}

The main contribution of this dissertation is introducing the view of realist social theory and its morphogenetic approach for studying the dynamics of governing activity and governance structures of PPPs. Additionally, each chapter contributes to the development of the theoretical debate of governance, projects, and organizations in different streams of management and organizational literature. In the first chapter, we contribute to the theory of inter-organizational governance in projects (Cao \& Lumineau, 2015). The central discussion in this branch of literature is the extent to which relational and contractual governance operate either as substitutes or as complements. Our point of departure was critically assessing the limits of functionalist and economics perspectives on organized activities 
to account for the actuality of projects. This study disregards contractual and relational governance as mutual excluding phenomena in PPPs, which is the prevailing view in inter-organizational studies (Cao \& Lumineau, 2015; Poppo \& Zenger, 2002). By investigating the role of relational aspects in mediating the relationship between contractual governance and perceived project performance (Zenger et al., 2000), we argued that relations are necessary components of executing contracts. Therefore, the main contribution of the first chapter is the conceptualization of the interplay between contractual and relational governance and their impact on performance as a mediation process.

In the second chapter, our contribution is framed in the recent turn to social theory and the concern for explaining why projects evolve the way they do (Cruickshank, 2007; Floricel et al., 2014; Mutch, 2018b). The turn-to-practice in project management enabled scholars to consider the possibility that governing activity (re)creates the forms of governance beyond front-end governance designs and policy (Blomquist et al., 2009; Brunet, 2019). However, their reliance on Giddens ontology of practices placed in a black box how governing activity changes or reproduces governance structure in place (Archer, 1995; Cruickshank, 2007). First, we pointed out that relative positions of control and autonomy enable practices (Reed, 2001). Therefore, we discussed positioned-practices rather than practices (Bhaskar, 1998; Fleetwood, 2004). The position of managers in the grid of relations that configure projects, organizations, and fields is the condition of possibility for governing activity practices in PPPs. The governing practices reproduce or change relative positions, which enables specific groups some practices and not others. This feedback can only operate overtime. Based on this clarification, the second chapter provides a process-framework to open this black box in the study of ongoing PPPs. Additionally, we postulated a causal mechanism accounting for the path of governing activity operating during the process of change and reproduction of project governance structures. The mechanism was defined as the individual managerial capacity to reflect, conceal or prioritize often conflicting demands from their dual position as members of temporary and permanent organizations.

In Chapter 3, the introduction of realist sociology in studying project governance allowed us to address existing theoretical challenges in temporary organizing-as-process in organizational studies (Bakker et al., 2016). In this stream of the literature, the idea of "mutual constitution" and the ontology of practices blurred the temporary and permanent boundaries, limiting their capacity to explain tensions, synergies and conflicts emerging from their interface (Söderlund \& Sydow, 2019; Jörg Sydow \& Braun, 2017; J. Sydow et al., 2004). Accordingly, we conceptualized the temporary and permanent interface from a morphogenetic perspective to account for the nature of PPPs as long-term agreements which can outlast the organizational relations and fields (Brookes et al., 2017; South et al., 2018). Governance structures of temporary organizations emerge from a temporary organizing practice legitimized for the time being due to the historical configuration of autonomy and control relations at field level. Once the governance structure of the temporary organization is formalized in a temporary binding agreement, it acquires relative autonomy as a relational structure by its own terms. The autonomy is expressed in internal positions and vested interests, shaping the tension between value-creation and capture to be solved by managerial agency powers.

Our reliance on Critical Realism allowed us to provide an account of the (re)creation of governance structures and governing activity avoiding voluntarism and determinism (Archer, 1995). To avoid conflation of agency and structure, we situated the sui-generis in the context of field transformations 
(Reed, 2001). We defined a field in terms of a latticework of control and autonomy relations between actors entering in organizational situations, including forms of organized activity, technologies and practices (Fleetwood, 2008). As field configuration is socio-historically contingent, we stated that initial PPP agreements include latent contradictions and synergies with the structural properties of the operative and policy context. In the specific Dutch case, we complement the insights into PPP institutional bricolage at the policy level by providing evidence about the role of project managers agency (Koppenjan \& de Jong, 2018). The managerial agency was expressed by the informal configuration of a community of practice within the procurement organization to strengthen their professional autonomy and capacities while shaping policy change.

Additionally in Chapter 3, we coined the concept creative enactment of contractual bonds. This means situations where managers build a collaborative working relationship based upon but not reduced to contractual entitlements. We found that attributing meaning to the contract beyond legal entitlements allowed managers to conceal the tension of value capture for parent organizations and value co-creation at the project level. Furthermore, project paths regarded as satisfactory were those which project actors attribute meaning to the project relation beyond their contractual basis, or use the spirit of the contract as a reference for working activities. However, putting meaning to contractual entitlements in a non-pure legal fashion is predisposed by the initial terms of the PPP agreement and the contingent outcomes of previous cycles of interaction.

In Chapter 4 we further elaborated the idea that objective bounds can be enacted with higher or lower levels of subjectivity for contributing to PPP process management literature (Edelenbos \& Klijn, 2009; Klijn, 2008). Process management literature in Public Administration had already pointed out that re-creating of legitimacy is the key to successful PPPs (Edelenbos \& Klijn, 2009; Klijn, 2008). We add the concept of "creative enactment of contractual relations" between project managers to this body of knowledge. The creative enactment of contractual relations opens up the opportunity to develop trust as a relational good emerging from but that is not reduced to the individual psychological dispositions. The working relationship provides the grounds for re-legitimizing the fairness and clarity of the contractual entitlements.

Putting Critical Realism into action is also a contribution to organizational and management studies (Al-Amoudi \&Willmott, 2011; Edwards et al., 2014). One constant challenge in this PhD undertaking was avoiding the reduction of the morphogenetic approach to a pure methodological device. We used it first as a framework to a study an open systemic process at project level (Chapter 2), and then we linked the sui-generis and micro morphogenetic cycle at the project level with the macro-dynamics of field changes (Chapter 3). Furthermore, we used the morphogenetic approach following the commitment of ontological boldness, epistemological relativity and judgmental rationality (Archer, 1995; Mutch, 2018b). In this regard, we discuss neo-institutional economics (Poppo \& Zenger, 2002), project-aspractice (Blomquist et al., 2009), and temporary organizing-as-process assumptions (Bakker et al., 2016) in the light of the morphogenetic approach to avoid agency-structure conflation in explaining observed PPP governance activity. 


\section{METHODOLOGICAL CONTRIBUTION}

This thesis made some methodological contributions, taking into account the scope of each stage of research following the critical realist logic of discovery/explanation. The methodological contribution of the first stage is at the level of the empirical. We use updated SEM-PLSC guidelines to validate the theoretical model by assessing the overall fit of the model (Henseler et al., 2016). This validation is absent in the current literature, including Goo et al. (2009) and others using PLS-SEM (Lu et al., 2015). Their use of PLS-SEM is more exploratory, in the sense that they do not estimate the measurement and structural model misspecification. It is important to note that, for example, at the time Goo et al. (2009) and others conducted their research, fit measures for PLS were not available. In the case of model misspecifications, they would not have become aware of it. As testing the overall fit of a model in PLS is now available, it is possible to take a step forward and carry out confirmatory research.

In the third chapter, our contribution was adjusting the realist guidelines for conducting case studies in organizational studies from the perspective of the morphogenetic approach (Vincent \& Wapshott, 2014). We redefine configuration analysis as an initial structure of relations between organizational positions filled by people, susceptible to be described in terms of AGIL (Donati, 2013). AGIL stands for A-means (or adaptation criteria), G-goals, I-norms (or integration), L-values (or latency) as orientations of meaning of social facts (e.g. action, exchange, relation, structure, system, network) by the agents/ actors who generate or maintain these social facts as meaningful wholes overtime (Donati, 2017). We redefine normative analysis in terms of morphogenetic cycles, which AGIL structural properties change in four possible directions from T1 to T4 (Donati, 2013). It includes Morphostasis (X $\rightarrow$ YS), Developmental Morphogenesis $(X \rightarrow Y D)$, Purely Interactional Morphogenesis $(X \rightarrow Y I)$ and Creative Morphogenesis $(X \rightarrow Y G)$. For the field analysis, we explicitly situated reproduction and change of governance project structures within the wider dynamics of control and autonomy relations at the field level. Additionally, we re-frame a typical constructivist methodological tool such as narrative analysis from a realist perspective (Murray \& Sools, 2014). We set the AGIL framework in relation to the five storyline elements (actors/character, acts/events, means/helpers, setting/scene, and desired or feared goal). In the constructivist perspective of narrative analysis, a narrative is told to conceal a breach of meaning or imbalance between the five elements. In our perspective informed by a realist ontology, the breaching of meaning of a narrative is part of informants' reflexivity on the structural relations. Therefore, the breach of meaning necessarily indicates the position of the actor and the direction of change of his/her activity, reproducing or altering the objective bounds of their working relations.

Likewise, we re-framed serious gaming aligned with the philosophical standpoint of Critical Realism. Serious games for procurement and project governance resembles the controlled-setting or closed system of experimental research, to safely explore/learn how specific rules would shape collaborative/ adversarial relations in reality (Altamirano et al., 2008; Dzeng \& Wang, 2017; Nassar, 2003). However, scholars relying on social experimentation run the risk of taking outcomes only achievable in a closed environment as misleading metaphors of organization dynamics inherently open to contingency and creativity (Archer, 2013). In this regard, we frame the gaming experience as an invitation to reflect on practitioners interaction in the closed system (game) and the open system (practice). 


\section{PRACTICAL CONTRIBUTION}

The idea of creative enactment of contractual relationships following the Dutch school of PPP process management (Klijn, 2008; Klijn et al., 2007) (Chapter 4) is a reminder that the legitimacy of contractual relations need also be re-created by the activity of managers during the exploitation phase. You can implement a contract in a rather mechanical way or you can talk about what you are implementing. Reflecting together on what you have to implement is a step forward to building a working relationship that emerges from but should not be reduced to contractual entitlements. During the O\&M phase, you can promote the individual and collective capacity to consider objective situations and conditions to build a working relationship towards the development of trust as relational good. However, there are inherent contradictions that necessarily impose uneasy situations on peoples'lives. Four key potential conflictive situations should be noticed during the O\&M phase, if well resolved, can facilitate trust development as relational good.

- The DBFM contracting effectively transfer the risk of hidden construction defects to the private contractor. That does not mean that hidden defects are avoided. In fact, they often occur. Their emergence sometimes leads to ambiguity, where parties can engage an adversarial contractual interpretation pushing for framing problems as open items from previous D\&B phase or change in the scope to be priced as a change in the O\&M.

- DBFM establishes levels of service that are often different from the users' service expectations. Meeting these expectations during the O\&M implies extra investments in a situation where the contractor does not have economic incentives for offering a competitive price. Additionally, prices include the life-cycle cost, which increases the difficulty to assess price fairness by the public party. Defining prices when introducing changes is a key moment to build trust and legitimacy of the contractual engagement.

- In a DBFM setting, the principal typically only defines functional specifications of a change. It is the contractor who is entitled to define the best means for meeting the change request, including the life-cycle cost. When a change is priced unexpectedly high, the principal has objective grounds for questioning whether (i) the contractor is overcharging, (ii) the contractor did not capture the actual need expressed in terms of functional specifications, or (iii) the principal simply does not understand the components of the life-cycle cost.

- DBFM restricts the possibility to include prohibitively expensive changes. They might increase the risk profile of the contractors. It is the responsibility of decision-makers to manage expectations of DBFM for introducing innovation and flexibility. DBFM contracting is designed for highly complex technical projects which are expected to be relatively stable. DBMF does not work for projects whose demand risk is rather unpredictable. The roots of distrust emerge from the perception that public authorities tender non-sustainable projects.

Furthermore, the actual value for money (providing either higher quality for the same level of public investment or lower investment for the same level of quality) depends on addressing the named four points during the O\&M phase. In Chapter 2, we develop a group model building activity to facilitate the discussion of these aspects with practitioners. Now, at the policy level, it is important to encourage the capacity for imagining innovative ways of professional and collaborative relationing. This is the case of the community of practices of asset managers documented in the third chapter of this thesis. Its 
symbolic value is bringing to light how informal groups emerge from articulating vested interest and concerns about expertise power and weak positions inside the public organization. Furthermore, the value of the community of practitioners turned into a more inclusive initiative. While at the beginning asset managers engaged in collective action to balance power, the community turned into a space for sharing expertise between different units. Together, practitioners strengthened their position in the implementation of DBFM contracts, contributing to the change of values and policy change at the field level. Rather than defining an agenda or aspects to be addressed by these type of community of practices, the point to emphasize is the need to connect the weaker organizational nodes. Beyond the four points previously exposed to build trust development in contracts, the functional aspects that a community of practitioners should address are better defined by those who face the day-to-day demands.

\section{LIMITATIONS AND FURTHER RESEARCH}

Social systems do not have relations, but they are relations. Likewise, governing PPP projects is better understood as a process where actors re-create the relations that grant their positioned-practices. Disentangling the web of relations unfolding at multiples levels over time provides an understanding of why PPP forms and governing activities happened and not otherwise. This dissertation elaborates on this idea to provide an innovative insight into the actuality of PPP projects, contributing to the current theoretical discussion in project governance literature, temporary organizing, and PPP process management. This undertaking was inspired by the research cycles of discovery/explanation prescribed by the critical realist perspective. In this regard, we also embraced method plurality running statistical analysis, engaging in action research activities, group model building, cross-case comparison, narrative analysis, and serious gaming. However, there are several limitations and also research challenges to be considered.

From the empirical point of view, the statements on performance are defined from the perspective of subjective satisfaction rather than using "objective" indicators. As we explained in Chapter 1, there are different value claims and interests in projects, let alone that the higher number of different stakes in PPPs increases the ambiguity when measuring an overall "good outcome". On the other hand, no DBFM project was finalized at the moment of designing and writing this thesis. Therefore, it was not possible to assess PPP life-cycle cost for making reliable statements on value-for-money. The need for ex-post assessment has already identified in PPPs review literature. It is difficult to support a processview in longitudinal research designs due to the long-term nature of PPP projects.

At the conceptual level, there are several challenges that can be addressed in further research from a realist perspective. First, there is a need to better conceptualize the differentiation between the structural and cultural components of conditioning in our process model of temporary organizing. In Chapter 2, we pointed out that one central tenet of critical realist theory is the analytical differentiation between culture and material/political structure. We included them as the general definition of beliefs, while Archer (1995) warns that their relations in terms of contradiction and complementarity are independent. This aspect is particularly relevant to address a second conceptual point not resolved in 
this research: our standpoint towards the institutional scholarship in organizational studies. The cultural aspect for Archer regards the systems of beliefs which properties of contradiction and complementarity are independent of the knowing subject. This definition has a strong parallelism to institutional logics. It is a task for future research endeavours to clarify the implications of this parallelism to the processoriented framework for temporary organizing developed in this thesis. Similarly, in Chapter 3 we pointed out that we did not address the consequences of conflation in temporary organizing due to the articulation of the structuration argument with institutional work literature (Lawrence et al., 2009; Söderlund \& Sydow, 2019; Tukiainen \& Granqvist, 2016). Further research can discuss the position of analytical dualism in relation to the catch-all "institution" concept which includes "pattern of doings", along with structural regulations, norms, beliefs, and habits (Alvesson \& Spicer, 2019; Fleetwood, 2008; Mutch, 2018a).

In the same chapter, we pointed out that further research in temporary organizing should address the discussion between realist ontology and becoming ontology. We foresee that the discussion is the extent to which the former leads to essentialism and the later to indeterminacy in studying temporary organizing (Böhm \& De Cock, 2005; Donati, 2017; Emirbayer, 1997; Mutch et al., 2006; O'Mahoney, 2012; Tsoukas \& Chia, 2002). Another vein of theoretical and empirical elaboration is the articulation of the open systemic perspective used for analyzing the (re)production of project governance with the network dimension of the realist relational sociology adopted as theoretical reference (Donati, 2013). According to the original formulation of the realist relational sociology, while the systemic tradition such as the morphogenetic approach focuses on explaining change/reproduction, the network perspective better articulates the problem of control-autonomy. The idea of double position elaborated in Chapter 2, further developed in Chapter 3 and framed as "brokering" in Chapter 4 refers to network properties of managerial activity.

Finally, it was fascinating to see how current procuring practices realize the re-valorization of the corporatist Dutch tradition after the liberalization wave. A promising new research area is explaining the emergence of new codes of relationing in private networks, avoiding relational evils such as the colluding practices observed back in the 2000s. Accounting for this observed phenomena is a promising opportunity for understanding the social changes in our times and the role of projects and organizations in the recent socio-political context of counter-liberalization. 


\section{AKNOWLEDGEMENTS}

This research was made possible by the Dutch Research Council (NWO) under Grant No. 409-14-014. My deepest thanks to the "Governance for Smarting Public-Private Partnerships" research team and its partners.

All my admiration to my Promotor, Professor Geert Dewulf, and my daily supervisor, Professor Andreas Hartmann. They gave me the freedom to explore and mature my rather complex ideas on project governance while pushing for consistency and clarity. Geert continuously challenged me to make clear the added value of my realist approach in comparison to Structuration Theory and Organizational Institutionalism. Andreas invited me to explore the turn-to-practice in project management studies, while his critical feedback sharpened my theoretical and practical contributions.

I also want to acknowledge the influence of Professors Koopenjan and Klijn from Erasmus Rotterdam University. I relied on their seminal work on PPPs to ground my insights on project governance upon the larger context of public governance in the Netherlands. Furthermore, the survey used in the first chapter was the outcome of the collaboration between Twente University and Erasmus Rotterdam University. Finally, thanks to Professor Jorg Henseler, who coached me in SEM-PLS modelling. If I have seen farther, it is by standing on the shoulders of giants.

Thanks to Reset Management, Twynstra Gudde, and Rijkswaterstaat for opening the doors of their organizations. Reset Management kindly provided me access to the wider network of PPP practitioners, which eventually helped me to illustrate the process model explained in the second chapter. André Samuelsson's experience supporting PPP practitioners gave me an early insight into the "double role" of project managers. Discussions with Ellen Lastdrager and the rest of the Twynstra Gudde team enriched my understanding of "partnership" beyond DBFM projects. Even though most of these discussions are not included in this manuscript, I am glad for having had the chance to discuss the opportunities and challenges associated with new ways of partnering in the fourth industrial revolution.

The Rijkswaterstaat and private contractors provided an enabling environment for gaining a deep understanding of Dutch Public-Private Partnerships. These open conversations empirically supported my third chapter. Finally, thanks to the teams that played the game introduced in the fourth chapter, including students from Twente University, and staff from Reset Management, Rijkswaterstaat, Rijksvastgoedbedrijf and Deltares.

I would like to give a special thanks to Monica Altamirano and Juan David Parra. They are important intellectual influences, but they are mainly friends. Monica introduced me to the PPP world, and her work in innovative procurement practices inspired the design of the game presented in the fourth chapter. Now, I have the fortune to work with her in Deltares. Juan David, always eager to clarify my conceptual and theoretical doubts, introduced me to Critical Realism. 
There are several people who supported me with their friendship and companionship. Thanks to all of my colleagues from the Construction Management and Engineering Department-in particular to Denis, Marc, Ruth, Pinnie and Julieta. Thanks to Felipe, María and Daniel, who became confidantes. Thanks to Veronica, whose emotional support gave me the strength to face the increasing pressure during the last part of my research. Thanks to my Colombian friends in Enschede, who shared many different moments with me throughout this PhD journey. Thanks to Alejandro, Ernesto, Diego, Juana, Luis, Sara, Lorena and Raquel. Catalina, Laura and Paula supported me from a distance. Finally, thanks to my mom and brother, whose love gives meaning to my choices. 


\section{REFERENCES}

Ahola, T., Ruuska, I., Artto, K., \& Kujala, J. (2014). What is project governance and what are its origins? International journal of project management, 32(8), 1321-1332.

Al-Amoudi, I., \& Willmott, H. (2011). Where constructionism and critical realism converge: Interrogating the domain of epistemological relativism. Organization Studies, 32(1), 27-46.

Altamirano, M., \& de Jong, W. (2009). Opportunistic behaviour in road maintenance markets: Exploring the consequences through gaming simulation. Transportation Research Record: Journal of the Transportation Research Board(2108), 13-22.

Altamirano, M., Herder, P., \& De Jong, M. (2008). Road roles Using gaming simulation as decision technique for future asset management practices. Paper presented at the Systems, Man and Cybernetics, 2008. SMC 2008. IEEE International Conference on.

Alvesson, M., \& Spicer, A. (2019). Neo-institutional theory and organization studies: A mid-life crisis? Organizational Studies, 40(2), 199-218.

Anastasopoulos, P., Haddock, J., \& Peeta, S. (2014). Cost Overrun in Public-Private Partnerships: Toward Sustainable Highway Maintenance and Rehabilitation. Journal of Construction Engineering and Management, 140(6), 04014018-04014011-04014018-04014019

Archer, M. (1995). Realist social theory: The morphogenetic approach. New York: Cambridge University Press.

Archer, M. (2003). Structure, agency and the internal conversation. Cambridge: Cambridge University Press.

Archer, M. (2007). Making our way through the world: Human reflexivity and social mobility. Cambridge: Cambridge University Press.

Archer, M. (2011). Morphogenesis: Realism's explanatory framework. In A. Maccarini, E. Morandi, \& R. Prandini (Eds.), Sociological realism (pp. 66-101). Oxford: Routledge.

Archer, M. (2013). Morphogenic society: Self-government and self-organization as misleading metaphors. In M. Archer (Ed.), Social morphogenesis (pp. 145-164). Dordrecht: Springer.

Arellano-Gault, D., Demortain, D., Rouillard, C., \& Thoenig, J.-C. (2013). Bringing public organization and organizing back in. Organization Studies, 34(2), 145-167.

Arranz, N., \& Arroyabe, J. (2012). Effect of formal contracts, relational norms and trust on performance of joint research and development projects. British Journal of Management, 23(4), 575-588.

Atkinson, R. (1999). Project management: cost, time and quality, two best guesses and a phenomenon, its time to accept other success criteria. International journal of project management, 17(6), 337-342.

Aubry, M., Richer, M. C., Lavoie-Tremblay, M., \& Cyr, G. (2011). Pluralism in PMO performance: The case of a PMO dedicated to a major organizational transformation. Project Management Journal, 42(6), 60-77.

Bachmann, R. (2001). Trust, power and control in trans-organizational relations. Organization Studies, 22(2), 337-365.

Bachmann, R., \& Inkpen, A. C. (2011). Understanding institutional-based trust building processes in interorganizational relationships. Organization Studies, 32(2), 281-301.

Bakker, R. M., DeFillippi, R. J., Schwab, A., \& Sydow, J. (2016). Temporary organizing: Promises, processes, problems. Organization Studies, 37(12), 1703-1719.

Barlas, Y. (1996). Formal aspects of model validity and validation in system dynamics. System dynamics review, 12(3), 183-210.

Baron, R. M., \& Kenny, D. A. (1986). The moderator-mediator variable distinction in social psychological research: Conceptual, strategic, and statistical considerations. Journal of personality and social psychology, 51(6), 1173.

Benitez-Avila, C., Hartmann, A., \& Dewulf, G. (2019). Contractual and Relational Governance as Positioned Practices in Ongoing Public-Private Partnership Projects. Project Management Journal(Advance online publication). doi:https://doi.org/10.1177/8756972819848224

Benitez-Avila, C., Hartmann, A., Dewulf, G., \& Henseler, J. (2018). Interplay of relational and contractual governance in public-private partnerships: The mediating role of relational norms, trust and partners' contribution. International journal of project management, 36(3), 429-443. 
Bennon, M., Monk, A., \& Nowacki, C. (2015). Dutch Pensions Paving the Way for Infrastructure Development. Journal of Structured Finance, 21(2), 45.

Bhaskar, R. (1997). A realist theory of science: Routledge.

Bhaskar, R. (1998). The possibility of naturalism: A philosophical critique of the contemporary human sciences. London: Routledge.

Bing, L., Akintoye, A., Edwards, P. J., \& Hardcastle, C. (2005). The allocation of risk in PPP/PFI construction projects in the UK. International journal of project management, 23(1), 25-35.

Blanken, A. (2008). Flexibility against efficiency? An international study on value for money in hospital concessions. Enschede: University of Twente.

Blau, P. M. (1964). Exchange and power in social life. New Brunswick: Transaction Publishers.

Blomquist, T., Hällgren, M., Nilsson, A., \& Söderholm, A. (2009). Projects-as-Practice: Making project research matter. Project Management Research, 41(1), 5-16.

Blomquist, T., \& Packendorff, J. (1998). Learning from renewal projects: content, context and embeddedness. In R. A. Lundin \& C. Midler (Eds.), Projects as arenas for renewal and learning processes (pp. 37-46). New York: Springer.

Boardman, A. E., Greve, C., \& Hodge, G. A. (2015). Comparative Analyses of Infrastructure Public-Private Partnerships. Journal of Comparative Policy Analysis: Research and Practice, 17(5), 441-447.

Böhm, S., \& De Cock, C. (2005). Everything you wanted to know about organization theory... but were afraid to ask Slavoj Žižek. The Sociological Review, 53(1_suppl), 279-291.

Borys, B., \& Jemison, D. B. (1989). Hybrid arrangements as strategic alliances: Theoretical issues in organizational combinations. Academy of management review, 14(2), 234-249.

Brahm, F., \& Tarziján, J. (2015). Does complexity and prior interactions affect project procurement? Evidence from mining mega-projects. International journal of project management, 33(8), 1851-1862.

Braun, T., Ferreira, A. I., \& Sydow, J. (2013). Citizenship behaviour and effectiveness in temporary organizations. International journal of project management, 31(6), 862-876.

Bremer, W., \& Kok, K. (2000). The Dutch construction industry: a combination of competition and corporatism. Building Research \& Information, 28(2), 98-108.

Bresnen, M., Goussevskaia, A., \& Swan, J. (2004). Embedding new management knowledge in project-based organizations. Organization Studies, 25(9), 1535-1555.

Bresnen, M., \& Marshall, N. (2002). The engineering or evolution of co-operation? A tale of two partnering projects. International journal of project management, 20(7), 497-505.

Brookes, N., Sage, D., Dainty, A., Locatelli, G., \& Whyte, J. (2017). An island of constancy in a sea of change: Rethinking project temporalities with long-term megaprojects. International journal of project management, 35(7), 1213-1224.

Brunet, M. (2019). Governance-as-practice for major public infrastructure projects: A case of multilevel project governing. International journal of project management, 37(2), 283-297.

Bult-Spiering, M., \& Dewulf, G. (2006). Strategic issues in public-private partnerships: An international perspective. Oxford: Blackwell.

Burger, P., \& Hawkesworth, I. (2011). How to Attain Value for Money. OECD Journal on Budgeting, 11(1), 91-146.

Burke, C. M., \& Morley, M. J. (2016). On temporary organizations: A review, synthesis and research agenda. human relations, 69(6), 1235-1258.

Bygballe, L. E., Dewulf, G., Levitt, R., Carrillo, P., \& Chinowsky, P. (2013, 9-11 July). The impact of relational contracting on flexibility in health care projects. Paper presented at the Proceedings of Engineering Project Organization, Winter Park, CO, USA.

Bygballe, L. E., Dewulf, G., \& Levitt, R. E. (2015). The interplay between formal and informal contracting in integrated project delivery. Engineering Project Organization Journal, 5(1), 22-35.

Bygballe, L. E., Håkansson, H., \& Jahre, M. (2013). A critical discussion of models for conceptualizing the economic logic of construction. Construction Management and Economics, 31(2), 104-118.

Caetano, A. (2015). Defining personal reflexivity: A critical reading of Archer's approach. European Journal of Social Theory, 18(1), 60-75. 
Cao, Z., \& Lumineau, F. (2015). Revisiting the interplay between contractual and relational governance: A qualitative and meta-analytic investigation. Journal of Operations Management, 33, 15-42.

Chang, C. Y. (2013). A critical review of the application of TCE in the interpretation of risk allocation in PPP contracts. Construction Management and Economics, 31(2), 99-103.

Chen, L., \& Manley, K. (2014). Validation of an instrument to measure governance and performance on collaborative infrastructure projects. Journal of Construction Engineering and Management, 140(5), 355-377.

Churchill Jr, G. A. (1979). A paradigm for developing better measures of marketing constructs. Journal of marketing research, 16(1), 64-73.

Cicmil, S., \& Marshall, D. (2005). Insights into collaboration at the project level: complexity, social interaction and procurement mechanisms. Building Research \& Information, 33(6), 523-535.

Clegg, S. R., Pitsis, T. S., Rura-Polley, T., \& Marosszeky, M. (2002). Governmentality matters: designing an alliance culture of inter-organizational collaboration for managing projects. Organization Studies, 23(3), 317-337.

Cooper, R. (1990). Organization/disorganization. Information (International Social Science Council), 25(2), 299-335.

Cruickshank, J. (2003). Realism and sociology: Anti-foundationalism, ontology and social research. London: Routledge.

Cruickshank, J. (2007). Realism and sociology: Anti-foundationalism, ontology and social research (Vol. 5): Psychology Press.

Cruz, C. O., \& Marques, R. C. (2013). Flexible contracts to cope with uncertainty in public-private partnerships. International journal of project management, 31(3), 473-483.

Cui, C., Liu, Y., Hope, A., \&Wang, J. (2018). Review of studies on the public-private partnerships (PPP) for infrastructure projects. International journal of project management, 36(5), 773-794.

Das, T. K., \& Teng, B.-S. (1998). Between trust and control: Developing confidence in partner cooperation in alliances. Academy of management review, 23(3), 491-512.

Das, T. K., \& Teng, B.-S. (2001). Trust, control, and risk in strategic alliances: An integrated framework. Organization Studies, 22(2), 251-283.

Davies, A., Frederiksen, L., Dewulf, G., Taylor, J., \& Chinowsky, P. (2010, November 4-7). Business models, infrastructure and the changing public-private interface. Paper presented at the Engineering Project Organizations Conference, South Lake Tahoe, CO, US.

Davis, K. (2014). Different stakeholder groups and their perceptions of project success. International journal of project management, 32(2), 189-201.

De Brux, J. (2010). The dark and bright sides of renegotiation: an application to transport concession contracts. Utilities Policy, 18(2), 77-85.

De Castro e Silva Neto, D., Cruz, C. O., Rodrigues, F., \& Silva, P. (2016). Bibliometric Analysis of PPP and PFI Literature: Overview of 25 Years of Research. Journal of Construction Engineering and Management, 06016002.

De Vaujany, F.-X. (2008). Capturing reflexivity modes in IS: A critical realist approach. Information and Organization, 18(1), 51-72.

Deakin, S., \& Wilkinson, F. (1998). Contract Law and the Economics of Interorganizational Trust. In C. Lane \& R. Bachmann (Eds.), Trust Within and Between Organizations: Conceptual Issues and Empirical Applications. New York: Oxford University Press, Oxford.

DeFillippi, R., \& Sydow, J. (2016). Project Networks: Governance Choices and ParadoxicalTensions. Project Management Journal, 47(5), 6-17.

Delbridge, R., \& Edwards, T. (2013). Inhabiting institutions: Critical realist refinements to understanding institutional complexity and change. Organization Studies, 34(7), 927-947.

Dewulf, G., Blanken, A., \& Bult-Spiering, M. (2012). Strategic issues in public-private partnerships. London: WileyBlackwell

Dijkstra, T. K., \& Henseler, J. (2015). Consistent partial least squares path modeling. MIS quarterly, 39(2), 297-316.

Domingues, S., \& Zlatkovic, D. (2015). Renegotiating PPP Contracts: Reinforcing the 'P'in Partnership. Transport Reviews, 35(2), 204-225.

Donati, P. (2010). Relational sociology: A new paradigm for the social sciences: Routledge.

Donati, P. (2011). Relational sociology: A new paradigm for the social sciences. New York: Routledge. 
Donati, P. (2013). Morphogenesis and social networks: Relational steering not mechanical feedback. In M. Archer (Ed.), Social morphogenesis (pp. 205-231). New York: Springer.

Donati, P. (2015). Manifesto for a critical realist relational sociology. International Review of Sociology, 25(1), 86-109.

Donati, P. (2016). The'Relational Subject'According to a Critical Realist Relational Sociology. Journal of Critical Realism, 15(4), 352-375.

Donati, P. (2017). Relational Versus Relationist Sociology: A New Paradigm in the Social Sciences. Stan Rzeczy, 12(1), 15-66.

Donati, P., \& Archer, M. (2015). The relational subject. Cambridge: Cambridge University Press.

Dorée, A. G. (2004). Collusion in the Dutch construction industry: an industrial organization perspective. Building Research \& Information, 32(2), 146-156.

Douglas, S., Hood, C., Overmans, T., \& Scheepers, F. (2019). Gaming the system: building an online management game to spread and gather insights into the dynamics of performance management systems. Public Management Review, 21(10), 1560-1576.

Dubois, A., \& Gadde, L. (2002). The construction industry as a loosely coupled system: implications for productivity and innovation. Construction Management \& Economics, 20(7), 621-631.

Dupas, N., Marty, F., \&Voisin, A. (2011, 10 Dec). Partnership contracts, project finance and information asymmetries: from competition for the contract to competition within the contract? Paper presented at the Seminar of Economic Analysis of Public Law and Policies, Chaire MADP, Sciences Po., Paris.

Dyer, J. H., \& Chu, W. (2003). The role of trustworthiness in reducing transaction costs and improving performance: Empirical evidence from the United States, Japan, and Korea. Organization science, 14(1), 57-68.

Dzeng, R.-J., \& Wang, P.-R. (2017). C-negotiation game: An educational game model for construction procurement and negotiation. Automation in Construction, 75, 10-21.

Eccles, R. G. (1981). The quasifirm in the construction industry. Journal of Economic Behaviour \& Organization, 2(4), 335-357.

Edelenbos, J., \& Eshuis, J. (2012). The interplay between trust and control in governance processes: a conceptual and empirical investigation. Administration \& Society, 44(6), 647-674.

Edelenbos, J., \& Klijn, E. H. (2009). Project versus process management in public-private partnership: Relation between management style and outcomes. International Public Management Journal, 12(3), 310-331.

Edwards, P., O'Mahoney, J., \& Vincent, S. (2014). Studying organizations using critical realism: A practical guide. Oxford: Oxford University Press.

Emirbayer, M. (1997). Manifesto for a relational sociology. American journal of sociology, 103(2), 281-317.

Engwall, M. (2003). No project is an island: linking projects to history and context. Research policy, 32(5), 789-808.

Eshuis, J., \& Van Woerkum, C. (2003). Trust and monitoring in governance processes: lessons from landscape management by farmers in a Dutch municipality. Journal of Environmental Policy \& Planning, 5(4), 379-396.

Fallah-Fini, S., Triantis, K., Rahmandad, H., \& de la Garza, J. M. (2015). Measuring dynamic efficiency of highway maintenance operations. Omega, 50, 18-28.

Fallah囚Fini, S., Rahmandad, H., Triantis, K., \& de la Garza, J. M. (2010). Optimizing highway maintenance operations: dynamic considerations. System Dynamics Review, 26(3), 216-238.

Fassott, G., Fassott, G., Henseler, J., Henseler, J., Coelho, P. S., \& Coelho, P. S. (2016). Testing moderating effects in PLS path models with composite variables. Industrial management \& data systems, 116(9), 1887-1900.

Fineman, S., Gabriel, Y., \& Sims, D. (2009). Organizing \& organizations: Sage.

Fleetwood, S. (2004). An ontology for organisation and management studies. In S. Fleetwood \& S. Ackroyd (Eds.), Critical Realist Applications in Organisation and Management Studies (pp. 27-53). London: Routledge.

Fleetwood, S. (2008). Institutions and Social Structures 1. Journal for the Theory of Social Behaviour, 38(3), 241-265.

Fleetwood, S. (2017). The critical realist conception of open and closed systems. Journal of Economic Methodology, 24(1), 41-68.

Fleming, L., Mingo, S., \& Chen, D. (2007). Collaborative brokerage, generative creativity, and creative success. Administrative science quarterly, 52(3), 443-475.

Floricel, S., Bonneau, C., Aubry, M., \& Sergi, V. (2014). Extending project management research: Insights from social theories. International journal of project management, 32(7), 1091-1107. 
Flyvbjerg, B. (2006). Five misunderstandings about case-study research. Qualitative inquiry, 12(2), 219-245.

Flyvbjerg, B. (2013). From Nobel prize to project management: getting risks right. arXiv preprint arXiv:1302.3642.

Forsström, B. (2005). Value co-creation in industrial Buyer-seller Partnerships: Creating and Exploiting Interdependencies: an empirical case study. Abo Akademi University Press, Abo.

Francesconi, M., \& Muthoo, A. (2006). Control rights in public-private partnerships. Forschungsinstitut zur Zukunft der Arbeit Discussion Paper, 2143, 1-35

Gibbons, R. (2010). Inside organizations: Pricing, politics, and path dependence. Annual Review of Economics, 2(1), 337-365.

Giddens, A. (1976). New rules of sociological method: A positive critique of interpretative sociology. London: Hutchinson.

Giddens, A. (1979). Central Problems in Social Theory: Action, Structure, and Contradiction in Social Analysis. Berkeley: Univ of California Press.

Giddens, A. (1984). The Constitution of Society: Outline of the Theory of Structuration. Cambridge: Polity.

Gilson, R. J., Sabel, C. F., \& Scott, R. E. (2010). Braiding: The Interaction of Formal and Informal Contracting in Theory, Practice, and Doctrine. Columbia Law Review, 1377-1447.

Glaeser, E. L., Laibson, D. I., Scheinkman, J. A., \& Soutter, C. L. (2000). Measuring trust. The Quarterly Journal of Economics, 115(3), 811-846.

Goo, J., Kishore, R., Rao, H. R., \& Nam, K. (2009). The role of service level agreements in relational management of information technology outsourcing: an empirical study. MIS quarterly, 119-145.

Gopal, A., \& Koka, B. R. (2012). The Asymmetric Benefits of Relational Flexibility: Evidence From Software Development Outsourcing. Mis Quarterly, 36(2).

Graafland, J., \& van Liedekerke, L. (2011). Case description: Construction fraud. In European Business Ethics Cases in Context (pp. 261-276): Springer.

Grabher, G. (2002). Cool projects, boring institutions: temporary collaboration in social context. Regional studies, 36(3), 205-214.

Grabher, G. (2004). Temporary architectures of learning: Knowledge governance in project ecologies. Organization Studies, 25(9), 1491-1514.

Granovetter, M. (1985). Economic action and social structure: The problem of embeddedness. American journal of sociology, 91(3), 481-510.

Granqvist, N., \& Gustafsson, R. (2016). Temporal institutional work. Academy of Management Journal, 59(3), 1009-1035.

Grimsey, D., \& Lewis, M. K. (2002). Evaluating the risks of public private partnerships for infrastructure projects. International journal of project management, 20(2), 107-118.

Grimsey, D., \& Lewis, M. K. (2005). Are Public Private Partnerships value for money?: Evaluating alternative approaches and comparing academic and practitioner views. Accounting forum, 29(4), 345-378.

Gulati, R., \& Nickerson, J. A. (2008). Interorganizational trust, governance choice, and exchange performance. Organization Science, 19(5), 688-708.

Guo, F., Chang-Richards, Y., Wilkinson, S., \& Li, T. C. (2014). Effects of project governance structures on the management of risks in major infrastructure projects: A comparative analysis. International journal of project management, 32(5), 815-826.

Hair Jr, J. F., Hult, G. T. M., Ringle, C., \& Sarstedt, M. (2013). A primer on partial least squares structural equation modeling (PLS-SEM). London: Sage Publications.

Hällgren, M., \& Lindahl, M. (2017). Coping with lack of authority: Extending research on project governance with a practice approach. International Journal of Managing Projects in Business, 10(2), 244-262.

Hampel, C. E., Lawrence, T. B., \& Tracey, P. (2017). Institutional work: Taking stock and making it matter. In R. Greenwood, C. Oliver, T. B. Lawrence, \& R. Meyer (Eds.), The SAGE handbook of organizational institutionalism (pp. 558-590). London: Sage.

Hart, O. (2003). Incomplete contracts and public ownership: remarks, and an application to public-private partnerships. The Economic Journal, 113(486), C69-C76.

Hart, O., \& Moore, J. (2008). Contracts as reference points. The Quarterly Journal of Economics, 123(1), 1-48.

Hart, O., Shleifer, A., \& Vishny, R. W. (1996). The proper scope of government: theory and an application to prisons. Retrieved from 
Harteveld, C. (2011). Triadic game design: Balancing reality, meaning and play. London: Springer.

Hartmann, A., Davies, A., \& Frederiksen, L. (2010). Learning to deliver service-enhanced public infrastructure: balancing contractual and relational capabilities. Construction Management and Economics, 28(11), $1165-$ 1175.

Henderson, L. S., Stackman, R. W., \& Lindekilde, R. (2016). The centrality of communication norm alignment, role clarity, and trust in global project teams. International journal of project management, 34(8), 1717-1730.

Henisz, W. J., Levitt, R., \& Scott, W. R. (2012). Toward a unified theory of project governance: economic, sociological and psychological supports for relational contracting. Engineering Project Organization Journal, 2(1-2), 3755.

Henseler, J., Dijkstra, T. K., Sarstedt, M., Ringle, C. M., Diamantopoulos, A., Straub, D. W., . . Calantone, R. J. (2014). Common beliefs and reality about PLS: Comments on Rönkkö and Evermann (2013). Organizational Research Methods, 17(2), 182-209.

Henseler, J., Hubona, G., \& Ray, P. A. (2016). Using PLS path modeling in new technology research: updated guidelines. Industrial Management \& Data Systems, 116(1), 2-20.

Henseler, J., Ringle, C. M., \& Sinkovics, R. R. (2009). The use of partial least squares path modeling in international marketing. In R. R. Sinkovics \& P. Ghauri (Eds.), New challenges to international marketing (Vol. 20, pp. 277319). Bingley: Emerald Group Publishing Limited.

Herepath, A. (2014). In the loop: A realist approach to structure and agency in the practice of strategy. Organization Studies, 35(6), 857-879.

Hodge, G. A., Boulot, E., Duffield, C., \& Greve, C. (2017). After the Ribbon Cutting: Governing PPPs in the Medium to Long Term. Australian Journal of Public Administration, 76(3), 330-351.

Hodge, G. A., \& Greve, C. (2007). Public-private partnerships: an international performance review. Public administration review, 67(3), 545-558.

Hodge, G. A., \& Greve, C. (2010). Public-Private Partnerships: Governance Scheme or Language Game? Australian Journal of Public Administration, 69(s1), S8-S22.

Hodge, G. A., \& Greve, C. (2017). On public-private partnership performance: A contemporary review. Public Works Management \& Policy, 22(1), 55-78.

Hodge, G. A., Greve, C., \& Biygautane, M. (2018). Do PPP's work? What and how have we been learning so far? Public Management Review, 20(8), 1105-1121.

Hoecht, A. (2004). Control in collaborative research and technology development: a case study in the chemical industry. Journal of Managerial Psychology, 19(3), 218-234.

Hoezen, M. E. L. (2012). The competitive dialogue procedure: negotiations and commitment in inter-organisational construction projects. Enschede: University of Twente.

Hovmand, P. S. (2014). Community based system dynamics. New York: Springer.

Howard, M., Roehrich, J. K., Lewis, M. A., \& Squire, B. (2017). Converging and Diverging Governance Mechanisms: The Role of (Dys) Function in Long-term Inter-organizational Relationships. British Journal of Management, 30(3), 624-644

Huber, T. L., Fischer, T. A., Dibbern, J., \& Hirschheim, R. (2013). A process model of complementarity and substitution of contractual and relational governance in IS outsourcing. Journal of Management Information Systems, 30(3), 81-114.

Johnston, J., \& Gudergan, S. P. (2007). Governance of public-private partnerships: lessons learnt from an Australian case? International Review of Administrative Sciences, 73(4), 569-582.

Joslin, R., \& Müller, R. (2016). The relationship between project governance and project success. International journal of project management, 34(4), 613-626.

Kadefors, A. (2004). Trust in project relationships - inside the black box. International journal of project management, 22(3), 175-182

Kaiser, H. F. (1992). On Cliff's formula, the Kaiser-Guttman rule, and the number of factors. Perceptual and Motor Skills, 74(2), 595-598.

Karlsson, J. C., \& Ackroyd, S. (2014). Critical Realism, ResearchTechniques, and Research Designs. In P. Edwards, J. O'Mahoney, \& S. Vincent (Eds.), Studying organizations using critical realism (pp. 22-45). Oxford: Oxford University Press. 
Kaufmann, P. J., \& Dant, R. P. (1992). The dimensions of commercial exchange. Marketing Letters, 3(2), 171-185.

Ke, H., Cui, Z., Govindan, K., \& Zavadskas, E. K. (2015). The impact of contractual governance and trust on EPC projects in construction supply chain performance. Engineering Economics, 26(4), 349-363.

Ke, Y., Ling, F., \& Ning, Y. (2013). Public construction project delivery process in Singapore, Beijing, Hong Kong and Sydney. Journal of Financial Management of Property and Construction, 18(1), 6-25.

Kessler, I., \& Bach, S. (2014). Comparing cases. In P. Edwards, J. O’Mahoney, \& S. Vincent (Eds.), Studying Organizations Using Critical Realism (pp. 168-184). Oxford: Oxford University Press.

Kivleniece, I. (2013). Public-Private Governance, Uncertainty and Longevity Implications: Exploring the Developing World's Water Sector Partnerships. Paper presented at the 35th DRUID Celebration Conference, Barcelona, Spain.

Kivleniece, I., \& Quelin, B. V. (2012). Creating and capturing value in public-private ties: A private actor's perspective. Academy of Management Review, 37(2), 272-299.

Klijn, E. H. (2008). It's the management, stupid! Over het belang van management bij complexe beleidsvraagstukken. Den Haag: LEMMA.

Klijn, E. H., Edelenbos, J., \& Hughes, M. (2007). Public-private partnership: A two-headed reform. A comparison of PPP in England and the Netherlands. In C. Pollitt, S. Van Thiel, \& V. Homburg (Eds.), New Public Management in Europe (pp. 71-89). Hampshire: Palgrave.

Klijn, E. H., \& Koppenjan, J. (2016). The impact of contract characteristics on the performance of public-private partnerships (PPPs). Public Money \& Management, 36(6), 455-462.

Klijn, E. H., Steijn, B., \& Edelenbos, J. (2010). The impact of network management on outcomes in governance networks. Public administration, 88(4), 1063-1082.

Kolb, D. A., Boyatzis, R. E., \& Mainemelis, C. (2001). Experiential Learning Theory: Previous Research and New Directions in Perspectives on Thinking, Learning, and Cognitive Styles (Educational Psychology Series).

Koppenjan, J., \& de Jong, M. (2018). The introduction of public-private partnerships in the Netherlands as a case of institutional bricolage: The evolution of an AngloखSaxon transplant in a Rhineland context. Public Administration, 96(1), 171-184.

Kort, I. M., Verweij, S., \& Klijn, E. H. (2016). In search for effective public-private partnerships: An assessment of the impact of organizational form and managerial strategies in urban regeneration partnerships using fsQCA. Environment and Planning C: Government and Policy, 34(5), 777-794.

Kumaraswamy, M., Zou, W., \& Zhang, J. (2015). Reinforcing relationships for resilience-by embedding end-user 'people'in public-private partnerships. Civil Engineering and Environmental Systems, 32(1-2), 119-129.

Lahdenperä, P. (2012). Making sense of the multi-party contractual arrangements of project partnering, project alliancing and integrated project delivery. Construction Management and Economics, 30(1), 57-79.

Langley, A., Smallman, C., Tsoukas, H., \& Van de Ven, A. H. (2013). Process studies of change in organization and management: Unveiling temporality, activity, and flow. Academy of management journal, 56(1), 1-13.

Lawrence, T. B., Suddaby, R., \& Leca, B. (2009). Institutional work: Actors and agency in institutional studies of organizations. Cambridge: Cambridge University Press.

Lenferink, S., Tillema, T., \& Arts, J. (2013). Towards sustainable infrastructure development through integrated contracts: Experiences with inclusiveness in Dutch infrastructure projects. International journal of project management, 31(4), 615-627.

Levitt, R., Garvin, M., Scott, W. R., Dewulf, G., Monk, A., \& South, A. (2014). Toward a Integrated Lifecycle Governance Framework for Delivering Civil Infrastructure Projects through Public-Private Partnerships (P3). Paper presented at the Engineering Project Organization Conference, Devil's Thumb Ranch, Colorado.

Levitt, R., Henisz, W. J., \& Settel, D. (2009). Defining and mitigating the governance challenges of infrastructure project development and delivery. Paper presented at the 2009 Conference on Leadership and Management of Construction.

Lewicki, R. J., \& Bunker, B. B. (1996). Developing and maintaining trust in work relationships. In R. M. Kramer \& T. R. Tyler (Eds.), Trust in organizations: Frontiers of theory and research (pp. 114-139). Thousand Oaks: Sage.

Li, J. J., Poppo, L., \& Zhou, K. Z. (2010). Relational mechanisms, formal contracts, and local knowledge acquisition by international subsidiaries. Strategic Management Journal, 31(4), 349-370.

Lieftink, B., Smits, A., \& Lauche, K. (2019). Dual dynamics: Project-based institutional work and subfield differences in the Dutch construction industry. International journal of project management, 37(2), 269-282. 
Ligthart, R., Oerlemans, L., \& Noorderhaven, N. (2016). In the shadows of time: A case study of flexibility behaviours in an interorganizational project. Organization Studies, 37(12), 1721-1743.

Lincoln, J. R. (1982). Intra-(and inter-) organizational networks. Research in the Sociology of Organizations, 1(1), 1-38.

Ling, F., Ong, S., Ke, Y., Wang, S., \& Zou, P. (2014). Drivers and barriers to adopting relational contracting practices in public projects: Comparative study of Beijing and Sydney. International journal of project management, 32(2), 275-285

Liu, W.-H., \& Cross, J. A. (2016). A comprehensive model of project team technical performance. International journal of project management, 34(7), 1150-1166.

Lu, P., Guo, S., Qian, L., He, P., \& Xu, X. (2015). The effectiveness of contractual and relational governances in construction projects in China. International journal of project management, 33(1), 212-222.

Lu, W., Zhang, L., \& Zhang, L. (2016). Effect of Contract Completeness on Contractors' Opportunistic Behaviour and the Moderating Role of Interdependence. Journal of Construction Engineering and Management, 142(6), 04016004

Lui, S. S., \& Ngo, H.-y. (2004). The role of trust and contractual safeguards on cooperation in non-equity alliances. Journal of management, 30(4), 471-485.

Lundin, R. A., \& Söderholm, A. (1995). A theory of the temporary organization. Scandinavian Journal of management, 11(4), 437-455.

Luo, Y. (2002). Contract, cooperation, and performance in international joint ventures. Strategic management journal, 23(10), 903-919.

Macneil, I. R. (1980). The new social contract: An inquiry into modern contractual relations. New Heaven: Yale University Press.

Mahoney, J. T., McGahan, A. M., \& Pitelis, C. N. (2009). Perspective-the interdependence of private and public interests. Organization Science, 20(6), 1034-1052.

Malhotra, D., \& Lumineau, F. (2011). Trust and collaboration in the aftermath of conflict: The effects of contract structure. Academy of Management Journal, 54(5), 981-998.

Malhotra, D., \& Murnighan, J. K. (2002). The effects of contracts on interpersonal trust. Administrative Science Quarterly, 47(3), 534-559.

Manning, S. (2008). Embedding projects in multiple contexts-a structuration perspective. International journal of project management, 26(1), 30-37.

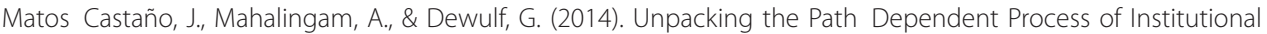
Change for PPPs. Australian journal of public administration, 73(1), 47-66.

Mayer, I. S. (2009). The gaming of policy and the politics of gaming: A review. Simulation \& Gaming, 40(6), 825-862.

McGuire, M., \& Agranoff, R. (2011). The limitations of public management networks. Public Administration, 89(2), 265-284.

McKay, J., \& Marshall, P. (2001). The dual imperatives of action research. Information Technology \& People, 14(1), 46-59.

Medlin, C., \& Quester, P. (2002). Inter-firm trust: Two theoretical dimensions versus a global measure. Paper presented at the Proceedings of the 18th annual IMP conference, Autumn 2002, Perth, Australia.

Ménard, C. (1996). The economics of hybrid organizations. Journal of Institutional and Theoretical Economics, 160(3), 1-32.

Meng, X. (2012). The effect of relationship management on project performance in construction. International journal of project management, 30(2), 188-198.

Meyerson, D., Weick, K. E., \& Kramer, R. M. (1996). Swift trust and temporary groups. In R. M. Kramer \& T. R. Tyler (Eds.), Trust in organizations: Frontiers of theory and research (pp. 166-195). Thousand Oaks: Sage.

Mitgutsch, K., Schirra, S., \& Verrilli, S. (2013). Movers and shakers: Designing meaningful conflict in a tablet-based serious game. Paper presented at the CHI'13 Extended Abstracts on Human Factors in Computing Systems.

Molenar, D. J., \& Wijnants, G. H. (2001). Toetsende rol Inventarisiatie grijze gebieden WBI. Retrieved from Delft: https:// www.cob.nl/wp-content/uploads/2018/01/6.18-Risicobeheersing-WB-1.pdf

Murray, M., \& Sools, A. (2014). Narrative research. Qualitative Research in Clinical and Health Psychology. London: Palgrave, 133-154. 
Mutch, A. (2007). Reflexivity and the institutional entrepreneur: A historical exploration. Organization Studies, 28(7), 1123-1140.

Mutch, A. (2018a). Practice, Substance, and History: Reframing Institutional Logics. Academy of Management Review, 43(2), 242-258.

Mutch, A. (2018b). Reframing Institutional Logics: Substance, Practice and History. New York: Routledge.

Mutch, A., Delbridge, R., \& Ventresca, M. (2006). Situating organizational action: The relational sociology of organizations. Organization, 13(5), 607-625.

Nassar, K. (2003). Construction contracts in a competitive market: C3M, a simulation game. Engineering, Construction and Architectural Management, 10(3), 172-178.

Nicolini, D. (2013). Practice theory, work, and organization: An introduction. Oxford: Oxford University Press.

Ning, Y., \& Ling, F. Y. Y. (2013). Reducing hindrances to adoption of relational behaviours in public construction projects. Journal of Construction Engineering and Management, 139(11), 04013017.

Nitzl, C., Roldan, J. L., \& Cepeda, G. (2016). Mediation analysis in partial least squares path modeling: Helping researchers discuss more sophisticated models. Industrial Management \& Data Systems, 116(9), 1849-1864.

Nooteboom, B. (1996). Trust, opportunism and governance: A process and control model. Organization Studies, 17(6), 985-1010.

O'Mahoney, J. (2012). Embracing essentialism: a realist critique of resistance to discursive power. Organization, 19(6), 723-741.

OECD. (2012). Recommendation of the Council on Principles for Public Governance of Public-Private Partnerships. (C(2012)86). Retrieved from http://www.oecd.org/governance/budgeting/PPP-Recommendation.pdf

Olander, H., Hurmelinna-Laukkanen, P., Blomqvist, K., \& Ritala, P. (2010). The dynamics of relational and contractual governance mechanisms in knowledge sharing of collaborative R\&D projects. Knowledge and Process Management, 17(4), 188-204.

Orlikowski, W. J., \& Yates, J. (2002). It's about time: Temporal structuring in organizations. Organization science, 13(6), 684-700.

Poppo, L., \& Zenger,T. (2002). Do formal contracts and relational governance function as substitutes or complements? Strategic management journal, 23(8), 707-725.

Poppo, L., Zhou, K. Z., \& Ryu, S. (2008). Alternative origins to interorganizational trust: An interdependence perspective on the shadow of the past and the shadow of the future. Organization Science, 19(1), 39-55.

Porpora, D. (2001). Do realists run regressions. In J. Lopez \& G. Potter (Eds.), After postmodernism: an introduction to critical realism (pp. 260-268). London: The Athlone Press.

Procaccino, J. D., Verner, J. M., Shelfer, K. M., \& Gefen, D. (2005). What do software practitioners really think about project success: an exploratory study. Journal of Systems and Software, 78(2), 194-203.

Rangan, S., Samii, R., \& Van Wassenhove, L. (2006). Constructive partnerships: When alliances between private firms and public actors can enable creative strategies. Academy of Management Review, 31(3), 738-751.

Reed, M. I. (1997). In praise of duality and dualism: rethinking agency and structure in organizational analysis. Organization Studies, 18(1), 21-42.

Reed, M. I. (2001). Organization, trust and control: a realist analysis. Organization Studies, 22(2), 201-228.

Rhodes, R. A. (2007). Understanding governance: Ten years on. Organization Studies, 28(8), 1243-1264.

Ring, P., \& Van de Ven, A. (1994). Developmental processes of cooperative interorganizational relationships. Academy of management review, 19(1), 90-118.

Roehrich, J. K. (2009). The dynamics of inter-organisational governance: contractual and relational mechanisms in public-private supply arrangements. University of Bath, Bath.

Rönkkö, M., \& Ylitalo, J. (2011). PLS marker variable approach to diagnosing and controlling for method variance. Paper presented at the ICIS 2011 Proccedings.

Rousseau, D. M., Sitkin, S. B., Burt, R. S., \& Camerer, C. (1998). Not so different after all: A cross-discipline view of trust. Academy of management review, 23(3), 393-404.

Rufín, C., \& Rivera-Santos, M. (2012). Between commonweal and competition: Understanding the governance of public-private partnerships. Journal of Management, 38(5), 1634-1654. 
Ryall, M. D., \& Sampson, R. C. (2009). Formal contracts in the presence of relational enforcement mechanisms: Evidence from technology development projects. Management Science, 55(6), 906-925.

Sahlin-Andersson, K., \& Söderholm, A. (2002). Beyond project management: New perspectives on the temporarypermanent dilemma. Copenhagen: Liber.

Sahmer, K., Hanafi, M., \& Qannari, M. (2006). Assessing unidimensionality within PLS path modeling framework. In M. Spiliopoulou, R. Kruse, C. Borgelt, A. Nurberger, \&W. Gaul (Eds.), From data and information analysis to knowledge engineering (pp. 222-229). Berlin: Springer.

Sanderson, J. (2012). Risk, uncertainty and governance in megaprojects: A critical discussion of alternative explanations. International journal of project management, 30(4), 432-443.

Sayer, A. (1992). Method in social science: A realist approach. London: Routledge.

Saz-Carranza, A., \& Longo, F. (2012). Managing competing institutional logics in public-private joint ventures. Public Management Review, 14(3), 331-357.

Schepker, D. J., Oh, W.-Y., Martynov, A., \& Poppo, L. (2014). The many futures of contracts moving beyond structure and safeguarding to coordination and adaptation. Journal of Management, 40(1), 193-225.

Scott, R. E., \& Triantis, G. G. (2005). Incomplete contracts and the theory of contract design. Case W. Res. L. Rev., 56, 187.

Scott, W. R. (1983). Organizations and organizing: Rational, natural and open systems perspectives. Englewood Cliffs: Prentice Hall.

Scott, W. R. (2013). Institutions and organizations: Ideas, interests, and identities: Sage Publications.

Segars, A. H., \& Grover, V. (1998). Strategic information systems planning success: an investigation of the construct and its measurement. MIS quarterly, 22(2), 139-163.

Shi, S., Chong, H.-Y., Liu, L., \& Ye, X. (2016). Examining the Interrelationship among Critical Success Factors of Public Private Partnership Infrastructure Projects. Sustainability, 8(12), 1313.

Simard, M., Aubry, M., \& Laberge, D. (2018). The utopia of order versus chaos: A conceptual framework for governance, organizational design and governmentality in projects. International journal of project management, 36(3), 460-473.

Sminia, H. (2011). Institutional continuity and the Dutch construction industry fiddle. Organization Studies, 32(11), 1559-1585.

Smith, N., Zhang, H., \& Zhu, Y. (2004). The Huaibei power plant and its implications for the Chinese BOT market. International journal of project management, 22(5), 407-413.

Söderlund, J., \& Borg, E. (2018). Liminality in management and organization studies: Process, position and place. International Journal of Management Reviews, 20(4), 880-902.

Söderlund, J., \& Sydow, J. (2019). Projects and institutions: towards understanding their mutual constitution and dynamics. 37(2), 259-268.

South, A., Eriksson, K., \& Levitt, R. (2018). How Infrastructure Public-Private Partnership Projects Change Over Project Development Phases. Project Management Journal, 49(4), 62-80.

Staber, U., \& Sydow, J. (2002). Organizational adaptive capacity: A structuration perspective. Journal of management inquiry, 11(4), 408-424.

Starkey, K., Barnatt, C., \& Tempest, S. (2000). Beyond networks and hierarchies: Latent organizations in the UK television industry. Organization Science, 11(3), 299-305.

Steinmetz, G. (2004). Odious comparisons: Incommensurability, the case study, and "small N's" in sociology. Sociological theory, 22(3), 371-400.

Sterman, J. (2000). Business dynamics: systems thinking and modeling for a complex world. Boston: McGraw-Hill.

Stevenson, W. B. (1990). Formal structure and networks of interaction within organizations. Social Science Research, 19(2), 113-131.

Stinchcombe, A. L. (1984). Contracts as hierarchical documents. Oslo: Institute of Industrial Economics.

Stjerne, I. S., Söderlund, J., \& Minbaeva, D. (2018). Crossing times: Temporal boundary-spanning practices in interorganizational projects. International Journal of Project Management.

Stjerne, I. S., \& Svejenova, S. (2016). Connecting temporary and permanent organizing: Tensions and boundary work in sequential film projects. Organization Studies, 37(12), 1771-1792. 
Strong, K., \& Chhun, S. (2014). Complex governance system issues for transportation renewal projects. Urban, Planning and Transport Research, 2(1), 233-246.

Suprapto, M., Bakker, H. L. M., \& Mooi, H. G. (2015). Relational factors in owner-contractor collaboration: The mediating role of teamworking. International journal of project management, 33(6), 1347-1363.

Svejvig, P., \& Andersen, P. (2015). Rethinking project management: A structured literature review with a critical look at the brave new world. International journal of project management, 33(2), 278-290.

Swärd, A. (2016). Trust, reciprocity, and actions: The development of trust in temporary inter-organizational relations. Organization Studies, 37(12), 1841-1860.

Sydow, J., \& Braun, T. (2017). Projects as temporary organizations: An agenda for further theorizing the interorganizational dimension. International Journal of Project Management.

Sydow, J., Lindkvist, L., \& DeFillippi, R. (2004). Project-based organizations, embeddedness and repositories of knowledge. Organization Studies, 25(9).

Sydow, J., \& Staber, U. (2002). The institutional embeddedness of project networks: the case of content production in German television. Regional studies, 36(3), 215-227.

Tang, L., Shen, Q., \& Cheng, E. (2010). A review of studies on public-private partnership projects in the construction industry. International journal of project management, 28(7), 683-694.

Teisman, G., van Buuren, A., \& Gerrits, L. M. (2009). Managing complex governance systems. New York: Routledge.

Thompson, J. D. (1967). Organizations in action: Social science bases of administrative theory. Boston: McGraw-Hill.

Tsoukas, H., \& Chia, R. (2002). On organizational becoming: Rethinking organizational change. Organization science, 13(5), 567-582.

Tukiainen, S., \& Granqvist, N. (2016). Temporary organizing and institutional change. Organization Studies, 37(12), 1819-1840.

Tuominen, T. M., \& Lehtonen, M. H. (2017). The Emergence of Transformative Agency in Professional Work. Organization Studies, 0170840617717093.

Turner, J. R., \& Müller, R. (2003). On the nature of the project as a temporary organization. International journal of project management, 21(1), 1-8.

Van Daalen, C., Schaffernicht, M., \& Mayer, I. (2014). System dynamics and serious games. Paper presented at the $32^{\text {nd }}$ International Conference of the System Dynamics Society, Delft, The Netherlands, 20-24 July 2014; Authors version.

Van den Belt, M. (2004). Mediated modeling: a system dynamics approach to environmental consensus building. London: Island press.

Van den Ende, L., \& Van Marrewijk, A. (2019). Teargas, taboo and transformation: A neo-institutional study of community resistance and the struggle to legitimize subway projects in Amsterdam 1960-2018. International journal of project management, 37(2), 331-346.

Van den Hurk, M., \& Verhoest, K. (2015). The governance of public-private partnerships in sports infrastructure: Interfering complexities in Belgium. International journal of project management, 33(1), 201-211.

Van Marrewijk, A. (2017). The Multivocality of Symbols: A Longitudinal Study of the Symbolic Dimensions of the High-Speed Train Megaproject (1995-2015). Project Management Journal, 48(6), 47-59.

Vennix, J. A. M. (1996). Group model building: Facilitating team learning using system dynamics. London: Wiley Chichester.

Verweij, S. (2015). Once the shovel hits the ground. Erasmus Rotterdam University

Verweij, S., \& Gerrits, L. M. (2015). How satisfaction is achieved in the implementation phase of large transportation infrastructure projects: A qualitative comparative analysis into the A2 tunnel project. Public Works Management \& Policy, 20(1), 5-28.

Verweij, S., Klijn, E. H., Edelenbos, J., \& Van Buuren, A. (2013). What makes governance networks work? A fuzzy set qualitative comparative analysis of 14 Dutch spatial planning projects. Public Administration, 91(4), 10351055.

Verweij, S., Teisman, G. R., \& Gerrits, L. M. (2017). Implementing public-private partnerships: How management responses to events produce (un) satisfactory outcomes. Public works management \& policy, 22(2), 119-139.

Villani, E., Greco, L., \& Phillips, N. (2015). Business Models and Institutional Complexity: Understanding Value Creation in Healthcare Sector Public-Private Partnerships. Retrieved from 
Villani, E., Greco, L., \& Phillips, N. (2017). Understanding Value Creation in Public-Private Partnerships: A Comparative Case Study. Journal of Management Studies, 54(6), 876-905.

Vincent, S., \& Wapshott, R. (2014). Critical realism and the organizational case study: A guide to discovering institutional mechanisms. In D. Edwards, J. O'Mahoney, \& S. Vincent (Eds.), Studying organizations using critical realism: A practical guide (pp. 148-167).

Volker, L., \& Hoezen, M. (2017). Client learning across major infrastructure projects. In K. Haugbølle \& D. Boyd (Eds.), Clients and Users in Construction: Agency, Governance and Innovation (pp. 139-153). London: Routledge.

Wang, H.-K., Tseng, J.-F., \& Yen, Y.-F. (2014). How do institutional norms and trust influence knowledge sharing? An institutional theory. Innovation, 16(3), 374-391.

Wang, S., \& Bunn, M. D. (2004). Government/business relationships: insights into contract implementation. Journal of Public Procurement, 4(1), 84.

Wang, Y., Chen, Y., Fu, Y., \& Zhang, W. (2017). Do prior interactions breed cooperation in construction projects? The mediating role of contracts. International journal of project management, 35(4), 633-646.

Warsen, R., Klijn, E. H., \& Koppenjan, J. (2019). Mix and Match: How Contractual and Relational Conditions Are Combined in Successful Public-Private Partnerships. Journal of Public Administration Research and Theory, 29(3), 375-393.

Watanatada, T., Harral, C., Paterson, W., Dhareshwar, A., Bhandari, A., \& Tsunokawa, K. (1987). The Highway Design and Maintenance Standards Model - Description of the HDM-III Model (The World Bank, Washington, DC) Vol. 1.

Weihe, G. (2008). Public-private partnerships and public-private value trade-offs. Public Money and Management, 28(3), 153-158.

Williamson, O. (1981). The economics of organization: The transaction cost approach. American journal of sociology, 87(3), 548-577.

Winch, G. M. (2010). Managing construction projects. London: John Wiley \& Sons.

Windeler, A., \& Sydow, J. (2001). Project networks and changing industry practices collaborative content production in the German television industry. Organization Studies, 22(6), 1035-1060.

Winter, M., Smith, C., Morris, P., \& Cicmil, S. (2006). Directions for future research in project management: The main findings of a UK government-funded research network. International journal of project management, 24(8), 638-649.

Woolthuis, R. K., Hillebrand, B., \& Nooteboom, B. (2005). Trust, contract and relationship development. Organization Studies, 26(6), 813-840.

World-Bank. (2014). Public-Private Partnerships reference guide 2.0. In. Retrieved from http://www-wds.worldbank. org/external/default/WDSContentServer/WDSP/IB/2014/09/08/000442464_20140908133431/Rendered/ PDF/903840PPPORefe0Box385311B000PUBLIC0.pdf

Wu, A., Wang, Z., \& Chen, S. (2017). Impact of specific investments, governance mechanisms and behaviours on the performance of cooperative innovation projects. International journal of project management, 35(3), 504-515.

Xu, Y., Sun, C., Skibniewski, M. J., Chan, A. P., Yeung, J. F., \& Cheng, H. (2012). System Dynamics (SD)-based concession pricing model for PPP highway projects. International journal of project management, 30(2), 240-251.

Xue, J., Yuan, H., \& Shi, B. (2016). Impact of Contextual Variables on Effectiveness of Partnership Governance Mechanisms in Megaprojects: Case of Guanxi. Journal of Management in Engineering, 33(1), 04016034.

Yang, Z., Su, C., \& Fam, K.-S. (2012). Dealing with institutional distances in international marketing channels: Governance strategies that engender legitimacy and efficiency. Journal of Marketing, 76(3), 41-55.

Yescombe, E. R. (2011). Public-private partnerships: principles of policy and finance. London: Elsevier.

Zenger, T. R., Lazzarini, S. G., \& Poppo, L. (2000). Informal and formal organization in new institutional economics. In P. Ingram \& B. S. Silverman (Eds.), The new institutionalism in strategic management (pp. 277-305). Bingley: Emerald Group Publishing Limited.

Zhang, H., Jin, R., Li, H., \& Skibniewski, M. J. (2017). Pavement maintenance-focused decision analysis on concession periods of PPP highway projects. Journal of Management in Engineering, 34(1), 04017047. 
Zhang, S., Zhang, S., Gao, Y., \& Ding, X. (2016). Contractual governance: Effects of risk allocation on contractors' cooperative behaviour in construction projects. Journal of Construction Engineering and Management, 142(6), 04016005.

Zhang, Z., Wan, D., Jia, M., \& Gu, L. (2009). Prior ties, shared values and cooperation in public-private partnerships. Management and Organization Review, 5(3), 353-374.

Zhao, X., Lynch Jr, J. G., \& Chen, Q. (2010). Reconsidering Baron and Kenny: Myths and truths about mediation analysis. Journal of consumer research, 37(2), 197-206.

Zheng, J., Roehrich, J. K., \& Lewis, M. A. (2008). The dynamics of contractual and relational governance: evidence from long-term public-private procurement arrangements. Journal of Purchasing and Supply Management, 14(1), 43-54.

Zhou, Y., Zhang, X., Zhuang, G., \& Zhou, N. (2015). Relational norms and collaborative activities: roles in reducing opportunism in marketing channels. Industrial Marketing Management, 46, 147-159. 